\title{
MUTAGÊNESE E TECNOLOGIA IN VITRONO MELHORAMENTO GENÉTICO DA PIMENTA-DO-REINO (Piper nigrum L.)
}

\author{
Oriel FilgueIRA DE Lemos
}

Tese apresentada à Escola Superior de Agricultura

"Luiz de Queiroz", Universidade de São Paulo, para

obtenção do título de Doutor em Agronomia, Área de

Concentração: Genética e Melhoramento de Plantas.

\author{
PIRACICABA \\ Estado de São Paulo - Brasil \\ Janeiro -2003
}




\title{
MUTAGÊNESE E TECNOLOGIA IN VITRONO MELHORAMENTO GENÉTICO DA PIMENTA-DO-REINO (Piper nigrum L.)
}

\section{ORIEL FILGUEIRA DE LEMOS}

Engenheiro Agrônomo

Orientador: Prof. Dr. AKIHIKO ANDO

Tese apresentada à Escola Superior de Agricultura

"Luiz de Queiroz", Universidade de São Paulo, para obtenção do título de Doutor em Agronomia, Área de Concentração: Genética e Melhoramento de Plantas.

\author{
PIRACICABA \\ Estado de São Paulo - Brasil \\ Janeiro - 2003
}




\section{Dados Internacionais de Catalogação na Publicação (CIP)} DIVISÃO DE BIBLIOTECA E DOCUMENTAÇÃO - ESALQ/USP

Lemos, Oriel Filgueira de Mutagênese e tecnologia in vitro no melhoramento genético da pimenta-do-reino (Piper nigrum L.) / Oriel Filgueira de Lemos. - - Piracicaba, 2003.

$$
159 \text { p. : il. }
$$

Tese (doutorado) - Escola Superior de Agricultura Luiz de Queiroz, 2003. Bibliografia.

1. Cultivo "in vitro" 2. Melhoramento genético vegetal 3. Mutagênese 4. Pimentado-reino 5. Propagação "in vitro" 6. Resistência à doença I. Título

CDD 633.84 
A Deus, pela clareza das coisas. Aos meus Pais, Joana Filgueira e Idamor Lemos, aos meus irmãos e à minha esposa, Rosinele Lemos e Lemos, pelo incentivo, compreensão e carinho dispensado,

— O f e r e ço -

\section{O sonho era realizar 0 impossível, tomou-se realidade com o possível a fazer e se concretizou com o necessário realizado, mas diante do feito, foi muito e tão pouco diante \\ de tanto a fazer.}

Para aquele com quem aprendi muito, pela amizade, experiência transmitida e pela oportunidade de fazer parte de sua história de muitas realizações, Prof Dr.

\section{Akihiko Ando,}

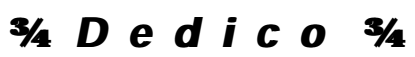




\section{AGRADECIMENTOS}

À Embrapa Amazônia Oriental, ao CENA/USP e ao Departamento de Genética da ESALQ/USP pela oportunidade e disposição de toda a infraestrutura necessária àrealização do curso.

Ao CNPq e à FAPESP pela concessão da bolsa e financiamento das pesquisas.

A todos do Laboratório de Melhoramento de Plantas do CENA/USP, especialmente à Inês Rodrigues, José Benedito Alves, Paulo Cassieri e Wlamir Godoy pelo auxílio nas atividades de pesquisas.

Aos Professores Dr. Francisco Javier Zapata-Arias, Dr. Augusto Tulmann Neto e Dr. Antonio Figueira, pelos ensinamentos transmitidos.

À bióloga Janaína Albino e à estudante de biologia Aline B. P. Fonseca pela parceria na condução de diversas atividades de pesquisas.

Às Pesquisadoras Marli C. Poltronieri e Ilmarina Campos de Menezes, Embrapa Amazônia Oriental, pela amizade, ajuda e alegria na condução dos trabalhos de campo.

Aos responsáveis pelas propriedades dos experimentos em campo, em ToméAçu, Pará, o Sr. Shigeru Inada e o agrônomo Germano da ASFATA,.

Ao Laboratório de Fitopatologia da Embrapa Amazônia Oriental, Belém, Pará, pela cessão dos isolados do fungo Fusarium solanif. sp. piperis.

Aos amigos e colegas, Rafael Alves, Raimundo Nonato Vieira, Rainério Meireles, Américo Reis, Rosângela Pena, Walter Bernardi, Dênmora Araujo, Márcia Scherer, Daniele Scoton, Laureen Kido, José Carlos e a todos que de alguma forma contribuiram para a realização deste trabalho. 


\section{SUMÁRIO}

Página

LISTA DE FIGURAS............................................................................ Viii

LISTA DE TABELAS........................................................................... $\quad x x i$

LISTA DE ABREVIATURAS E SÍMBOLOS.................................................. x xiii

RESUMO ...................................................................................

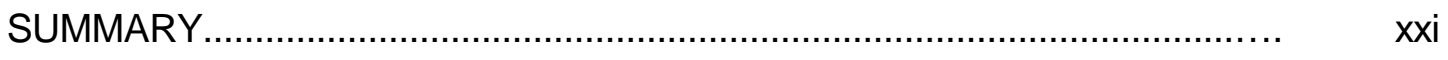

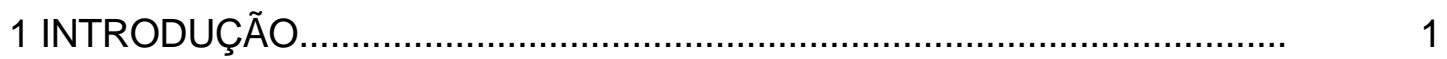

2 REVISÃO DE LITERATURA............................................................ 3

2.1 Cultura de pimenta-do-reino................................................................ 3

2.1.1 Considerações gerais................................................ 3

2.1.2 Importância sócio-econômica no Brasil................................................. 5

2.1.3 Métodos de propagação................................................................... 5

2.1.4 A doença fusariose......................................................................... 7

2.2 Aplicação das técnicas in vitro............................................................ 8

2.2.1 Micropropagação......................................................................... 9

2.2.2 Regeneração de plantas via organogênese........................................... 11

2.2.3 Regeneração de plantas via embriogênese somática............................ 12

2.3 Métodos de melhoramento genético em plantas..................................... 15

2.31. Métodos convencionais................................................ 16

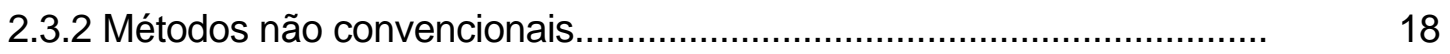

2.3.2.1 Indução de mutação.................................................................... 18

2.3.2.2 Indução de mutação associada æ̀s técnicas in vitro............................... 23

2.3.2.3 Seleção in vitro........................................................................ 25

2.3.2.4 Seleção através da obtenção de plantas transgênicas....................... 30

3 MATERIAL E MÉTODOS.................................................................... 33

3.1 Aplicação das técnicas in vitro.......................................................... 33 
3.1.1 Produção de plantas doadoras de explantes..........................................

3.1.1.1 A partir de estacas....................................................................... 35

3.1.1.2 A partir de sementes de cultivar tradicional........................................... 36

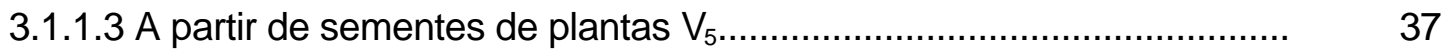

3.1.1.4 A partir de embriões zigóticos........................................................ 37

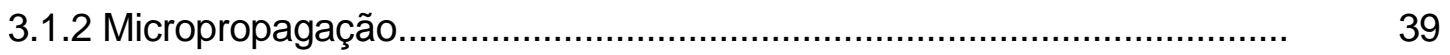

3.1.2.1 Estabelecimento e multiplicação de gemas......................................... 39

3.1.2.2 Alongamento e enraizamento de brotos............................................. 41

3.1.2.3 Aclimatação dos brotos enraizados e formação de mudas................... 43

3.1.2.4 Assepsia de explantes provenientes de plantas propagadas via

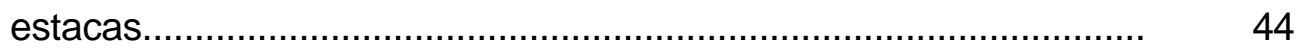

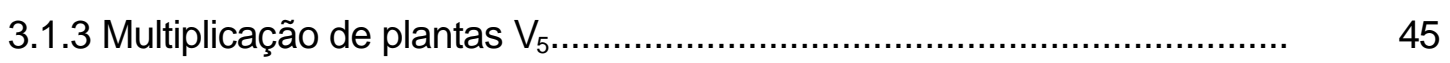

3.1.4 Indução de calos.........................................................................

3.2 Mutagênese e seleção de variantes contra a doença fusariose.................. $\quad 48$

3.2.1 Radiossensitividade de gemas in vitro àradiação gama......................... 48

3.2.2 Fitotoxicidade in vitro do filtrado de cultura do fungo Fusarium solani $\mathrm{f}$.

sp. piperis a gemas....................................................................... 50

3.2.3 Seleção in vitro de variantes sobreviventes ao filtrado da cultura do

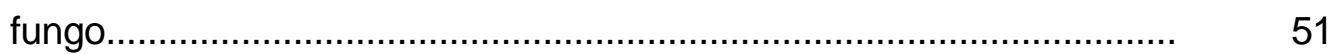

3.2.4 Determinação da concentração de esporos e modo de inoculação ......... 52

3.3 Avaliação agronômica de plantas oriundas de estacas tratadas com

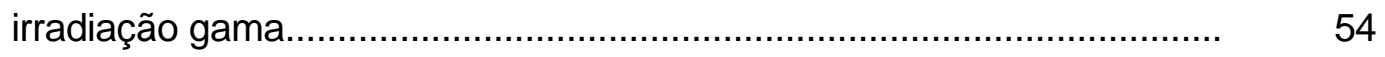

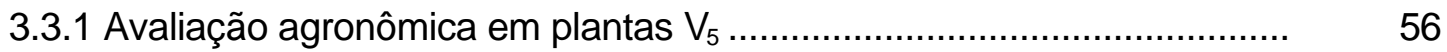

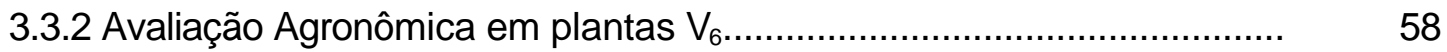

4 RESULTADOS E DISCUSSÃO ……………………............................ 59

4.1 Aplicação das técnicas in vitro............................................................... 59

4.1.1 Produção de plantas doadoras de explantes......................................... 59

4.1.1.1 A partir de estacas...................................................................... 59

4.1.1.2 A partir de sementes de cultivar Cingapura......................................... 61

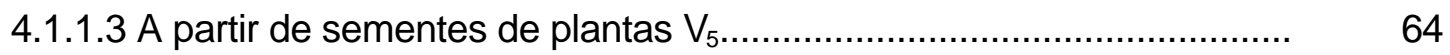

4.1.1.4 A partir de embriões zigóticos........................................................... 67

4.1.2 Micropropagação .............................................................................. 
4.1.2.1 Estabelecimento e multiplicação de gemas.......................................... 71

4.1.2.2 Alongamento e enraizamento de brotos.............................................. 79

4.1.2.3 Aclimatação dos brotos enraizados e formação de mudas.................... 88

4.1.2.4 Assepsia de explantes provenientes de plantas propagadas via

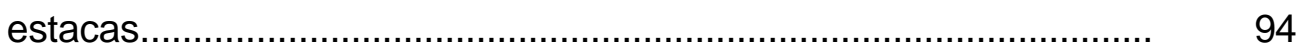

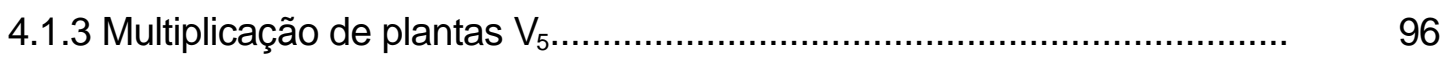

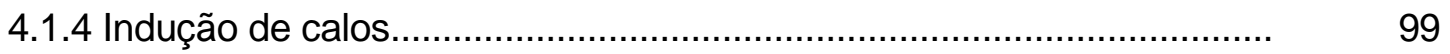

4.2 Mutagênese e seleção de variantes contra a doença fusariose.................. 109

4.2.1 Radiossensitividade de gemas in vitro àradiação gama......................... 109

4.2.2 Fitotoxicidade in vitro do filtrado de cultura do fungo Fusarium solani f.

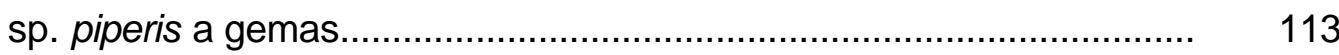

4.2.3 Seleção in vitro de variantes sobreviventes ao filtrado da cultura do fungo.

4.2.4 Determinação da concentração de esporos e modo de inoculação

4.3 Avaliação agronômica de plantas oriundas de estacas tratadas com

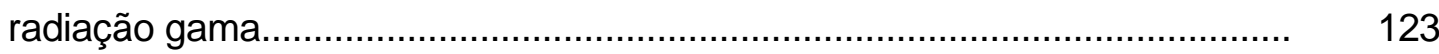

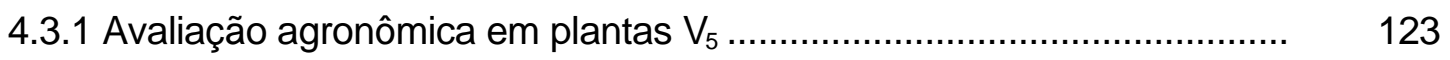

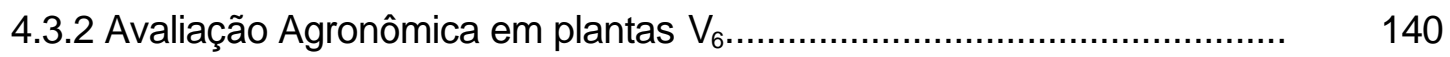

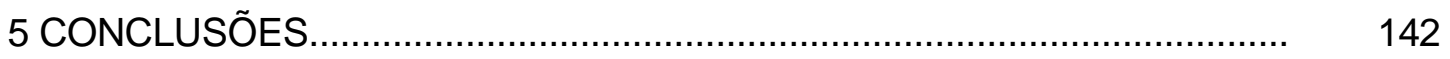

ANEXOS

REFERÊNCIAS BIBLIOGRÁFICAS........................................................... 150 


\section{LISTA DE FIGURAS}

Página

1 Características gerais da cultura...................................................

2 Metodologia para desenvolvimento das técnicas in vitro visando mutagênese e seleção de variantes tolerantes à doença fusariose

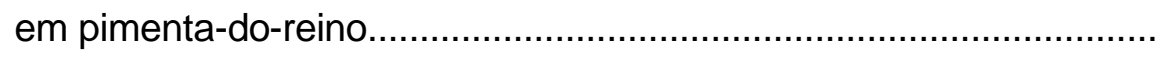

3 Fontes doadoras de explantes.....................................................

4 Teste de radiosensitividade de gemas in vitro com doses de radiação gama de 0 a 80 Gy e cultivo em meio de multiplicação de gemas..

5 Obtenção de filtrado e gemas em meio seletivo.

6 Experimento para a determinação do modo de aplicação e concentração da suspensão de esporos

7 Metodologia adotada para seleção de linhagens tolerantes àdoença fusariose a partir da irradiação gama em estacas de pimenta-doreino, avaliação agronômica, micropropagação e seleção de progênies contra o fungo

8 Instalação do experimento para avaliação de plantas $V_{5}$ quanto à incidência da doença fusariose e aos caracteres de produção das linhagens selecionadas..

9 Área com plantas $\mathrm{V}_{6}$, plantio em 1998 ......

10 Desenvolvimento de plantas de pimenta-do-reino doadoras de explantes.

11 Respostas in vitro de sementes a diferentes modificações do meio de cultura MS (69 dias após a inoculação).

12 Produção de plântulas doadoras de explantes a partir de 
sementes.

13 Conversão de embriões zigóticos em plântulas em diferentes meios de cultura (tratamentos 1 a 8, Tabela 9)

14 Multiplicação de gemas em meio básico MS.

15 Alongamento e enraizamento em meio básico de cultura MS.

16 Aclimatação e formação de mudas a partir de "plantlets".

17 Assepsia de explantes a partir de mudas propagadas via estacas.

18 Micropropagação de plantas $\mathrm{V}_{5}$

19 Indução de calos e obtenção de células em suspensão.

20 Efeito da radiação gama no peso dos explantes.

21 Efeito da radiação gama na sobrevivência dos explantes.

22 Efeito da radiação gama no número de gemas por explantes

23 Efeito da radiação gama nas doses de 0 a 50 Gy em gemas in vitro.

24 Curva de crescimento do fungo Fusarium solani f. sp. piperis cultivados em meio Czapek-Dox durante 35 dias.

25 Efeito de filtrados $\mathrm{FE}(\mathbf{A})$ e $\operatorname{All}(\mathbf{B})$ na não diferenciação de gemas..

26 Efeito de diferentes concentrações de filtrado (0, 20, 30, 40 e 50\%), como agente seletivo em meio de multiplicação de gemas, sob a forma de esterilização por filtro estéril (FE) - a e $\mathbf{b}-$ e duas autoclavagens - c e d, após 45 dias de cultivo.

27 Seleção in vitro de variantes originados por irradiação gama em gemas, sobreviventes ao agente seletivo filtrado da cultura do fungo Fusarium solani $f$. sp. piperis, após 6 semanas de cultivo.....

28 Plantas submetidas àinoculação com esporos do fungo (0 a 2×10 ${ }^{2}$, $10^{4}$ e $10^{6}$ esporos $/ \mathrm{ml}$ ).

29 Desenvolvimento e avaliação de plantas originadas a partir de estacas irradiadas.

30 Performance de caracteres de produção de pimenta-do-reino de 16 linhagens $V_{5}$ após seis anos de cultivo.

31 Performance de produção de pimenta-do-reino de 16 linhagens $V_{5}$ originadas de estacas irradiadas com raios-gama e uma linhagem 
testemunha (CT) após seis anos de cultivo................................. 127

32 Performance das linhagens $V_{5}$ durante três anos consecutivos quanto aos caracteres de produção...............................................

33 Evolução da sobrevivência das plantas das linhas $V_{5}$ em área de ocorrência da doença no período de 1999 a 2001(plantio mar/94).

34 Mortalidade e sobrevivência de plantas de linhagens $V_{5}$ durante 0 período de cultivo de 1994 a 2002 .....................................................

35 Gráfico de dispersão de 14 plantas $v_{5}$ quanto a diversidade genética obtida através de análise por componentes principais......

36 Análise da divergência genética por variáveis canônicas entre plantas originadas de estacas irradiadas e não irradiadas...................

37 Mortalidade e sobrevivência de plantas $V_{5}$ em área de ocorrência da

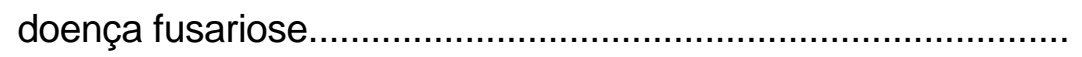




\section{LISTA DE TABELAS}

1 Tratamentos correspondentes ao balanço exógeno entre BAP e IAA para diferenciação de novas gemas em explantes visando à proliferação de brotos no processo de micropropagação de pimentado-reino.

2 Tratamentos correspondentes ao balanço exógeno entre BAP e IAA e carvão ativado em meio básico de cultura MS para diferenciação de novas gemas em explantes visando à proliferação de brotos no processo de micropropagação de pimenta-do-reino, em cada subcultivo.

Página

3 Tratamentos utilizados para enraizamento de gemas em meio básico MS com metade ou concentração completa dos sais, suplementado com NAA ou IBA nas concentrações de 0,0 a $5,0 \mu \mathrm{M}$.

4 Tratamentos para indução de calos a partir de segmentos de entrenós e de folha em meio de cultura básico SH suplementado com TDZ ou Dicamba combinado com BAP.

5 Tempo de irradiação de gemas, ras diferentes doses de radiação gama de acordo com a taxa de dose da fonte de ${ }^{60} \mathrm{Co}$ de "Gammacell", CENA/USP.

6 Respostas in vitro de sementes de pimenta-do-reino a diferentes composições de meio de cultura (69 dias após a inoculação)

7 Teste qui-quadrado para comparação dos principais tratamentos no desenvolvimento de plântula a partir de sementes da cultivar Cingapura.

8 Teste qui-quadrado para comparação dos efeitos de meios de cultura com $\mathrm{NaH}_{2} \mathrm{PO}_{4}$ e sem $\mathrm{NaH}_{2} \mathrm{PO}_{4}$ no desenvolvimento de plântula a partir de sementes da cultivar Cingapura.

9 Teste qui-quadrado para comparação dos efeitos de meios de cultura com carvão ativado e sem carvã̃o ativado no desenvolvimento de plântula a partir de sementes da cultivar Cingapura..

10 Teste qui-quadrado para comparação dos efeitos de meios de cultura com $\mathrm{NaH}_{2} \mathrm{PO}_{4}$ e com carvão ativado no desenvolvimento de plântula a partir de sementes da cultivar Cingapura

11 Análise em fatorial 2X2 e comparação de média de percentagem de

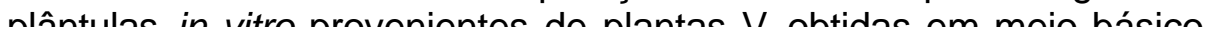


plântulas in vitro provenientes de plantas $\mathrm{V}_{5}$ obtidas em meio básico de cultura MS, com ou sem adição de $0,2 \%$ de carvão ativado (C. A.) combinado ou não com $0,17 \mathrm{~g} \cdot \mathrm{L}^{-1}$ de $\mathrm{NaH}_{2} \mathrm{PO} 4$.

12 Desenvolvimento de plântulas in vitro de linhagens de plantas $V_{5}$ e da cultivar Cingapura em meio básico de cultura MS com ou sem adição de carvão ativado a $0,2 \%$ combinado ou não com $0,17 \mathrm{~g} \cdot \mathrm{L}^{-1}$ de $\mathrm{NaH}_{2} \mathrm{PO}_{4}$

13 Teste qui-quadrado para comparação do desenvolvimento de plântula a partir de sementes das diferentes linhagens $V_{5}$ em condições in vitro.

14 Percentagem de plântulas de pimenta-do-reino desenvolvidas in vitro a partir de embriões zigóticos da cultivar Cingapura em meio básico de cultura MS com metade ou completa concentração dos sais e adição de diferentes suplementos.

15 Teste qui-quadrado para comparação dos principais tratamentos na diferenciação dos embriões cultivados em diferentes meios de cultura.

16 Teste qui-quadrado para comparação dos efeitos de meios de cultura com completa (MS) ou metade (1) da concentração de sais de MS na diferenciação de embriões zigóticos.

17 Análises da variância do delineamento inteiramente casualizado em fatorial 2X4 (BAP X IAA) quanto à proliferação de gemas em dois subcultivos consecutivos, a cada oito semanas.

18 Proliferação in vitro de brotos a partir de segmentos nodais e ápices caulinares de pimenta-do-reino em meio básico de cultura MS suplementado com diferentes combinações de concentrações de IAA $x$ BAP, subcultivados a cada oito semanas em dois subcultivos.

19 Análise da variância de efeito de duas concentrações de BAP na proliferação de brotos de pimenta-do-reino após 8 e 4 semanas em dois subcultivos, respectivamente.

20 Média de proliferação in vitro de brotos por explantes em meio básico de cultura MS suplementado com BAP por 8 e 4 semanas em dois subcultivos, respectivamente.

21 Análise da variância quanto ao efeito da combinação de BAP x IAA na proliferação de gemas de pimenta-do-reino em três subcultivos consecutivos, após 8, 6 e 6 semanas, respectivamente.

22 Média de proliferação in vitro de gemas por explante em meio básico de cultura MS suplementado com diferentes combinações de BAPxIAA em três subcultivos consecutivos, após 8,6 e 6 semanas, respectivamente.

23 Análise da variância conjunta dos três subcultivos quanto ao efeito da combinação de BAP x IAA na proliferação de gemas de pimenta-do- 
reino.

24 Média de gemas por explante em dois subcultivos consecutivos em meio básico MS com adição ou não de carvão ativado a $0,2 \%$, suplementado com diferentes combinações de BAPxIAA, aos 45 dias e 60 dias.

25 Análise da variância de proliferação de gemas por explante em dois subcultivos em meio básico de cultura MS com adição ou não de carvão ativado, suplementado com diferentes combinações de BAPXIAA.

26 Teste Tukey de comparação de médias $^{1}$ sobre a proliferação de gemas por explante em dois subcultivos em meio básico de cultura MS com adição ou não de carvão ativado, suplementado com diferentes combinações de BAPxIAA.....

27 Análise da variância, média de raiz por broto e percentagem de brotos enraizados em meio básico de cultura MS suplementado com NAA $\left(0,5 \mathrm{mg} \cdot \mathrm{L}^{-1}\right)$ e $\mathrm{GA}_{3}\left(0,0 ; 0,5 ;\right.$ ou $\left.1,0 \mathrm{mg} \cdot \mathrm{L}^{-1}\right)$ após 4 semanas de cultivo..

28 Análise da variância, média de raiz por broto e percentagem de brotos enraizados em meio básico de cultura MS suplementado com NAA $\left(0,0 ; 0,1 ; 0,5\right.$ e $\left.1,0 \mathrm{mg} \cdot \mathrm{L}^{-1}\right)$ após 4 semanas de cultivo.

29 Resposta à diferenciação de raízes e desenvolvimento caulinar de gemas em meio básico MS com adição ou não de carvão ativado a $0,2 \%$, suplementado com diferentes combinações de BAPxIAA, após 60 dias de cultivo.

30 Teste de comparação de média quanto a diferenciação de raízes e desenvolvimento caulinar a partir de gemas em meio básico MS com adição ou não de carvão ativado a $0,2 \%$, suplementado com diferentes combinações de BAPxIAA, após 60 dias de cultivo.

31 Diferenciação de brotos e raízes a partir de gemas cultivadas em meio básico de cultura MS suplementado com NAA ou IBA a diferentes concentrações, após 10 semanas de cultivo

32 Análise da variância quanto ao efeito de IBA ou NAA em seis níveis (0 a $5 \mu \mathrm{M}$ ) em meio básico de cultura MS com metade ou completa concentração dos sais na diferenciação de raízes e desenvolvimento caulinar, após 10 semanas de cultivo.

33 Teste de comparação de média quanto à percentagem de explantes com raízes quando gemas foram cultivadas em meio básico de cultura MS, com metade ou completa concentração de sais, suplementado com NAA ou IBA a diferentes concentrações, após 10 semanas de cultivo.

34 Teste de comparação de média quanto ao número de raízes por explante em meio básico de cultura MS, com metade ou completa concentração de sais, suplementado com NAA ou IBA a diferentes concentrações, após 10 semanas de cultivo. 
35 Teste de comparação de média quanto ao comprimento de raízes por explante enraizado em meio básico de cultura MS, com metade ou completa concentração de sais, suplementado com NAA ou IBA a diferentes concentrações, após 10 semanas de cultivo.

36 Teste de comparação de média quanto ao comprimento caulinar dos explante que enraizaram em meio básico de cultura MS, com metade ou completa concentração de sais, suplementado com NAA ou IBA a diferentes concentrações, após 10 semanas de cultivo.

37 Aclimatação de brotos enraizados originados de diferentes meios de cultura em substrato de vermiculita ou vermiculita e Plantmax , 21 dias após transplantio.

38 Teste qui-quadrado para comparação entre a aclimatação de plantlets provenientes e meios de cultura com e sem carvão ativado suplementado com diferentes combinações de BAPxIAA, em substrato do tipo vermiculita e vermiculita + Plantmax.

39 Teste qui-quadrado para comparação quanto a aclimatação dos "planlets" provenientes de meios de cultura com diferentes combinações de BAPxIAA

40 Aclimatação de brotos enraizados originados de diferentes meios de cultura em substrato de vermiculita ou vermiculita + Plantmax, 40 dias após transplantio.

41 Teste qui-quadrado quanto a aclimatação de plantlets em dois tipos de substrato provenientes de meios de cultura com metade ou completa concentração de MS suplementado com NAA

42 Teste qui-quadrado quanto a aclimatação de plantlets em dois tipos de substrato provenientes de meios de cultura com metade ou completa concentração de MS suplementado com IBA

43 Teste qui-quadrado quanto a aclimatação de "plantlets" sob a ação de meios de cultura com metade ou completa concentração de MS e de NAA e IBA æ̀s concentrações de 0,1 a 2,5 $\mu \mathrm{M}$.

44 Teste qui-quadrado quanto a aclimatação de plantlets provenientes de meio básico de cultura MS com NAA ou IBA a diferentes concentrações.

45 Efeito de tratamento de assepsia sobre a contaminação, sobrevivência e oxidação de explantes provenientes de plantas propagadas via estacas após 21 dias de cultivo.

46 Efeito de tratamentos de assepsia na sobrevivência de gemas originadas de plantas propagadas por estacas sob casa-devegetação.

47 Análise da variância de proliferação de gemas a partir do cultivo in vitro de explantes das diferentes linhagens $V_{5}$ em meio básico de cultura MS suplementado com BAP a 0,5 e IAA a 0,2 mg. $\mathrm{L}^{-1}$, após 6 
semanas de cultivo.

48 Teste Duncan para comparação de médias de proliferação de gemas a partir de explantes de 12 linhagens $V_{5}$ em meio básico de cultura MS suplementado com BAP e IAA com 0,5 e 0,2 mg. $\mathrm{L}^{-1}$, respectivamente.

49 Análise da variância em fatorial $2 \times 3 \times 2$ quanto à indução de calos em segmentos de entrenós cultivados em meio básico $\mathrm{SH}$ suplementado com dicamba $(5,10$ e $20 \mu \mathrm{M})$ ou TDZ $(0,1,0,5$ e 1,0 $\mu \mathrm{M})$ em combinação com BAP (0 e 1,0 $\mu \mathrm{M})$, após 30 dias de cultivo.

50 Indução de calos em meio básico SH suplementado com diferentes combinações de dicambaxBAP sob condições de luz e escuro, após 30 dias de cultivo.

51 Indução de calos em meio básico SH suplementado com diferentes combinações de TDZxBAP sob condições de luz e escuro, após 30 dias de cultivo.

52 Análise da variância de média de indução de calos e oxidação de explantes em meio básico de cultura $\mathrm{SH}$ suplementado com dicamba a 2,5 mg. $\mathrm{L}^{-1}$ em combinação com diferentes concentrações de BAP, após 45 dias de cultivo.

53 Teste de comparação de média de indução de calos e oxidação de explantes em meio básico de cultura $\mathrm{SH}$ suplementado com dicamba a 2,5 mg. $\mathrm{L}^{-1}$ em combinação com diferentes concentrações de BAP, após 45 dias de cultivo

54 Análise da variância em fatorial $2 \times 8$ quanto àindução de calos $e$ oxidação em dois tipos de explantes cultivados em meio básico MS suplementado com dicamba (2,0 mg. $\left.\mathrm{L}^{-1}\right)$ e BAP (02 mg. $\left.\mathrm{L}^{-1}\right)$ em combinação com $\mathrm{GA}_{3}$ ou nitrato de prata, após 30 dias de cultivo.

55 Efeito de meio básico de cultura MS suplementado com dicamba (2,0 $\mathrm{mg} \cdot \mathrm{L}^{-1}$ ) e BAP (02 mg. $\mathrm{L}^{-1}$ ) em combinação com $\mathrm{GA}_{3}$ ou nitrato de prata quanto à indução de calos e índice de oxidação em dois tipos de explantes, após 30 dias de cultivo.

56 Análise da variância de média de indução de calos e oxidação de explantes em meio básico de cultura $\mathrm{SH}$ suplementado com dicamba a $20 \mu \mathrm{M}$ em combinação com BAP e caseína hidrolisada, após 45 dias de cultivo.

57 Teste de comparação de média de indução de calos e oxidação de explantes em meio básico de cultura $\mathrm{SH}$ suplementado com dicamba a $20 \mu \mathrm{M}$ em combinação com BAP e caseína hidrolisada, após 45 dias de cultivo.

58 Indução de calos e nível de oxidação de explante em meio SH suplementado com tidiazuron em combinação com IAA, após 30 dias de cultivo. 
59 Indução de calos e nível de oxidação em dois tipos de explante em meio $\mathrm{SH}$ suplementado com dicamba em combinação com BAP, após 30 dias de cultivo.

60 Respostas de embriões zigóticos em cultivo em meio básico de cultura SH suplementado com dicamba em combinação com BAP, após 4 semanas.

61 Teste qui-quadrado quanto a efeito de dicamba e BAP em meio básico de cultura SH para indução de calos em embriões zigóticos, após 30 dias de cultivo.

62 Gemas submetidas àirradiação gama, média de multiplicação a partir de $V_{2}$ e gemas transferidas para seleção in vitro.

63 Efeito da dose de irradiação gama na sobrevivência, gemas e peso por explante, equação da reta, coeficiente de determinação e dose adequada para redução de 70 e $30 \%$ dos parâmetros avaliados.

64 Efeito da adição de diferentes concentrações do meio de cultura Czapek-Dox em meio de multiplicação de gemas na sobrevivência e proliferação de gemas por explante

65 Média de produção de esporos por ml entre 8 e 35 dias do cultivo do fungo Fusarium solani f . sp. piperis em meio de cultura de CzapekDox e peso seco das hifas produzidas.

66 Efeito do filtrado em adição ao meio de cultura de multiplicação de gemas na diferenciação de gemas por explante após 45 dias de cultivo.

67 Seleção in vitro de gemas através da sobrevivência em meio de cultura com agente seletivo sob duas concentrações do filtrado do fungo, após 6 semanas de cultivo

68 Comparação entre o efeito do filtrado da cultura do fungo sob duas formas de cultivo e concentrações em meio seletivo quanto à sobrevivência das gemas que passaram por irradiação gama, após 6 semanas de cultivo

69 Efeito de filtrado do fungo à conc entração de $55 \%$ na sobrevivência de gemas que sofreram irradiação gama após 6 semanas de cultivo.

70 Incidência da doença fusariose e sobrevivência de plantas.

71 Características da espiga, peso de 100 frutos e produção média por planta de pimenta verde das linhagens $V_{5}$ após seis anos de cultivo.....

72 Características da inflorescência (espiga) quanto ao comprimento, peso e número de frutos, avaliadas durante três anos consecutivos de produção.

73 Peso úmido de 100 frutos e produção das linhagens de plantas $V_{5}$ avaliadas em três anos consecutivos de produção. 
74 Variação quanto aos diferentes caracteres de produção e média de três anos das linhagens que apresentaram sobreviventes após oito anos de cultivo em área de ocorrência da doença fusariose em

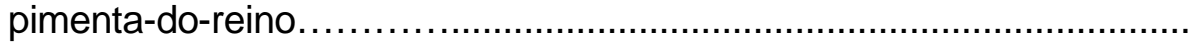

75 Performance das linhas $V_{5}$ no período de 1994 a 2002 quanto à mortalidade e sobrevivência das plantas.

76 Avaliação individual das plantas sobreviventes quanto aos caracteres

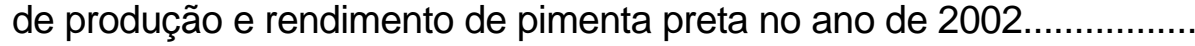

77 Performance de plantas $V_{6}$ quanto aos caracteres de produção e rendimento de pimenta preta avaliada em dois anos consecutivos....... 


\section{LISTA DE ABREVIATURAS E SÍMBOLOS}

\begin{tabular}{|c|c|}
\hline IAA & ácido indolacético \\
\hline NAA & ácido naftalenoacético \\
\hline $\mathrm{BAP}(\mathrm{BA})$ & 6-benzilamino purina (6-benziladenina) \\
\hline IBA & ácido indolbutírico \\
\hline Ácido giberélico $\left(\mathrm{GA}_{3}\right)$ & $\begin{array}{l}\text { 2,4a,7-trihidroxi-1-metil-8-metilene-gib-3-ene-1,10-ácido } \\
\text { carboxílico-1,4- lactona }\end{array}$ \\
\hline MS & meio básico de cultura de Murashige \& Skoog (1962) \\
\hline $\mathrm{SH}$ & meio básico de cultura de Schenk \& Hildebrandt (1972) \\
\hline Gy & quantidade de energia de radiação absorvida pelo material \\
\hline Tidiazuron (TDZ) & 1-fenil-3-(1,2,3-tidiazol-5-il) uréia \\
\hline 2,4-D & Ácido 2,4-dicloro fenoxiacético \\
\hline Cinetina $(\mathrm{CIN})$ & 6-furfurilaminopurina \\
\hline$V_{1}, \ldots V_{5}$, etc. & $\begin{array}{l}\text { Plantas que passaram por } \mathbf{n} \text { ciclos de propagação vegetativa } \\
\left(V_{n}\right) \text { após tratamento com mutagênico }\end{array}$ \\
\hline EMS & Metanossulfonato de etila \\
\hline DMSO & Dimetil sulfoxide \\
\hline DNA & Ácido desoxirribonucléico \\
\hline PCR & Reação da polimerase em cadeia \\
\hline ABA & Ácido abscísico \\
\hline $\mathrm{AgNO}_{3}$ & Nitrato de prata \\
\hline Etileno & $\mathrm{C}_{2} \mathrm{H}_{4}$ \\
\hline Dicamba (Dic.) & Ácido 3,6-dicloro-2-metoxibenzóico \\
\hline Zeatina (ZEA) & $\mathrm{N}^{6}$-(4-hidroxi-3-metillbut-2-enil) aminopurina \\
\hline 2ip & Isopenteniladenina \\
\hline
\end{tabular}




\title{
MUTAGÊNESE E TECNOLOGIA IN VITRO NO MELHORAMENTO GENÉTICO DA PIMENTADO-REINO (Piper nigrum L.)
}

\author{
Autor: ORIEL FILGUEIRA DE LEMOS \\ Orientador: Prof. Dr. AKIHIKO ANDO
}

\section{RESUMO}

O presente trabalho teve por objetivo desenvolver tecnologia in vitro e associá-la àmutagênese, e avaliar plantas $\mathrm{V}_{5} \mathrm{eV}_{6}$ quanto aos caracteres agronômicos de produção em área de ocorrência da doença fusariose, visando ao melhoramento genético da pimenta-do-reino para obtenção de plantas tolerantes e/ou resistentes à doença fusariose. A aplicação das técnicas in vitro iniciou-se através da obtenção de plantas doadoras de explantes, a partir de estacas em casa-de-vegetação e, de sementes e embriões zigóticos in vitro. O processo de micropropagação foi desenvolvido a partir de gemas de plantas obtidas in vitro através do estabelecimento de condições adequadas de cultivo em meios de cultura apropriados para multiplicação de gemas, enraizamento e obtenção de "plantlets", e de tipo de substrato para aclimatação e formação de mudas. Após a definição deste processo, gemas de plantas de casa-de-vegetação foram submetidas a diferentes tratamentos de assepsia e as sobreviventes micropropagadas. Seleção in vitro foi estabelecida ao cultivar isolados patogênicos do fungo Fusarium solani f. sp. piperis em meio Czapek-Dox e, através da curva de crescimento foi estabelecido o período de 28 dias de cultivo mais adequado para obtenção de filtrado da cultura do fungo. Diferentes concentrações de filtrado e formas de esterilização foram testadas em meio de cultura de multiplicação de gemas e determinou-se a concentração de $55 \%$ do filtrado do fungo ( $v / v)$ sob a esterilização por duas autoclavagens, adequada para causar 
$100 \%$ de mortalidade de gemas susceptíveis à doença. Simultaneamente, testes de radiossensitividade foram desenvolvidos através da irradiação gama em gemas in vitro e a dose de 20Gy foi escolhida para indução de mutações. As gemas irradiadas que passaram por vários ciclos de multiplicação e sobreviveram ao agente seletivo, filtrado de cultura do fungo, estão sendo clonadas para serem submetidas àseleção artificial com esporos do fungo em casa-de-vegetação, seleção natural em campo de ocorrência da doença e avaliação agronômica. Testes indicaram, a concentração de $2 \times 10^{6}$ esporos $/ \mathrm{ml}$ em suspensão e a aplicação no solo do fungo adequada para seleção em casa-devegetação. As plantas $V_{5}$ e $V_{6}$ avaliadas em campo quanto a mortalidade e caracteres de produção apresentaram performance semelhante às plantas da cultivar original quanto à média de comprimento de espiga $(8,4 \mathrm{~cm})$, peso $(4,42 \mathrm{~g})$ e número de frutos (40 frutos) por espiga, peso de 100 frutos $(10,67 \mathrm{~g})$ e rendimento de pimenta preta (> $30 \%$ ). Entretanto, melhores resultados para a média de produção de pimenta verde $(3.290 \mathrm{~g}) \mathrm{e}$ sobrevivência em área de ocorrência da fusariose. As análises por componentes principais e variáveis canônicas apresentaram divergência genética entre as plantas originadas por estacas que sofreram irradiação gama e aquelas da cultivar original. 


\title{
MUTAGENESIS AND IN VITROTECHNOLOGY IN THE GENETIC IMPROVEMENT OF BLACK PEPPER (Piper nigrum L.)
}

\author{
Author: ORIEL FILGUEIRA DE LEMOS
}

Adviser: Prof. AKIHIKO ANDO

\section{SUMMARY}

The purposes of the present work were to develop in vitro technology, associating it with mutagenesis, and to evaluate the $V_{5}$ and $V_{6}$ plants based on agronomical characters of production in Fusarium incidence areas, aiming at the genetic improvement of black pepper to obtain tolerant and/or resistant plants to the disease. The use of in vitro techniques started with the production of explant donor plants from greenhouse-grown cuttings and from seeds and in vitro zygotic embryos. The micropropagation process was developed using young shoots of in vitro plants by establishment of proper growing conditions in culture media for multiplication, rooting and production of plantlets, and by determining a suitable substrate type for acclimatization and growing of plantlets. After the process was defined, young shoots obtained from greenhouse grown plants underwent different aseptic treatments and the surviving plantlets were micropropagated. In vitro selection was carried out by cultivating pathogenic isolates of Fusarium solani f. sp. piperis in Czapek-Dox medium and, by using a growing curve, the most suitable growing period (28 days) for obtaining the fungus culture filtrate was defined. Different filtrate concentrations and sterilization techniques were tested in culture medium for young shoot multiplication. A concentration of $55 \%(\mathrm{v} / \mathrm{v})$ of fungus filtrate under sterilization by double autoclavation was considered adequate to cause $100 \%$ mortality of fusariosis susceptible young 
shoots. Simultaneously, radiosensitivity tests were carried out through gamma irradiation of in vitro young shoots and dose of 20Gy was selected for mutation induction. Irradiated young shoots which underwent several multiplication cycles and survived the selective agent, fungus culture filtrate, are being cloned in order to be submitted to artificial selection with the fungus spores in greenhouse, to natural selection in a disease incidence area and to agronomical evaluation. These tests indicated that the concentration of $2 \times 10^{6}$ spores $/ \mathrm{ml}$ in suspension and the application of the fungus on soil were appropriate for greenhouse selection. The $V_{5}$ and $V_{6}$ plants evaluated in field conditions for mortality and production characters showed similar performance to the original cultivar plants regarding average height $(8.4 \mathrm{~cm})$, weight (4.42g) and number of fruits (40 fruits) per spike, weight of 100 fruits (10.67g) and black pepper yield $(>30 \%)$. However, better results were observed for average green pepper production $(3,290 \mathrm{~g})$ and survival rates in a fusariosis incidence area. Analyses of principal components and canonic variables evidenced genetic divergence between plants grown from gamma-irradiated cuttings and the original cultivar ones. 


\section{INTRODUÇÃO}

A pimenta-do-reino (Piper nigrum L.) é uma planta originária da Índia que foi introduzida no Brasil no século XVII, mas seu cultivo somente foi difundido a partir de 1933 e intensificado no Estado do Pará por imigrantes japoneses. Em nível de produção mundial, o Brasil já se destacou como um dos maiores países produtores, chegando a produzir $50.000 \mathrm{t}$ em 1991. Ao longo dos anos subseqüentes, no entanto, a produção brasileira foi decrescendo, registrando 13.000 t em 1995 (Okajima, 1997), sendo 10.000 t produzidas no Estado do Pará.

Esta especiaria, produto tipicamente de exportação, apresenta grande oscilação de preço no mercado internacional, æ̀̀ vezes estimulando e outras desestimulando o cultivo. Entretanto, o que vem ocasionando sérios prejuízos, na produção e ciclo econômico, é a ocorrência da doença fusariose a nível epidêmico nas áreas de produção. Como conseqüência, o ciclo produtivo da cultura foi alterado, tornando-se mais curto, com uma média de cinco a seis anos de sobrevivência em área de ocorrência da doença.

Um dos fatores que tem contribuído para o agravamento do quadro produtivo é a vulnerabilidade genética das cultivares ao ataque do patógeno, e a rápida disseminação devido à homogeneidade das plantas. Isto se deve, principalmente, pela forma de propagação vegetativa utilizada, que favorece a disseminação da doença (material original de má qualidade) e torna os cultivos muito uniformes geneticamente, haja vista as cultivares serem susceptíveis àdoença.

Embora, haja disponibilidade de vários materiais de diferentes origens na coleção de pimenta-do-reino da Embrapa Amazônia Oriental, Belém, Pará, a variação genética entre esses materiais é muito estreita e todos os acessos têm apresentado susceptibilidade à doença fusariose. A dificuldade de introduzir material genético do centro de origem dificulta a obtenção de fontes de resistência. Desta forma, alguns 
métodos, convencionais ou não, devem ser utilizados visando ampliar essa estreita variabilidade.

Outras espécies do gênero Piper, nativas da Amazônia, têm apresentado níveis satisfatórios de tolerância à doença fusariose, tais como as espécies de Piper aduncum Linn., Piper colubrinum Link., Piper tuberculatum Jacq., P. hispidinervium C. D. C. e P. hispidum Sw, que podem ser utilizadas como fonte de resistência (Poltronieri et. al., 1999).

As técnicas in vitro se constituem em ferramentas valiosas na solução deste problema, seja através da propagação rápida de plantas livres de patógenos e clonagem de material elite, resgate de embrião de cruzamentos intra e interespecíficos, geração de variabilidade genética por mutações induzidas, seleção in vitro, produção de plantas transgênicas e análises genético-moleculares.

Dentre as alternativas de melhoramento genético, o uso da radiação gama como agente mutagênico em plantas tem indicado ser favorável sua aplicação para obtenção de mutantes com características agronômicas desejáveis (precocidade, tolerância à doença, etc.). Em pimenta-do-reino, Ando et al. (1984, 1997), após irradiação gama de estacas, selecionaram três plantas sobreviventes ao fungo Fusarium solani f. sp. piperis, as quais, após cinco gerações de propagação vegetativa (1978 a 1999), vêm apresentando tolerância em área de ocorrência da doença e precisam ser avaliadas quanto aos caracteres relacionados à produção para que possam ser indicadas.

A aplicação da mutagênese associada ao uso de tecnologia in vitro se constitui uma alternativa para ampliar a variabilidade genética, reduzir o tempo na seleção de mutantes, e clonar e multiplicar o material selecionado. Deste modo, permitir a avaliação agronômica em campo e por conseguinte, a recomendação e a adoção de uma nova cultivar ou incorporação em programas de melhoramento genético da cultura. Seleção in vitro, com filtrado da cultura do fungo, de variantes tolerantes ao Fusarium após tratamento mutagênico foi obtida em bananeira (Matsumoto et al. 1999), em abacaxizeiro (Hidalgo et al., 1998; Borras et al., 2001) e em soja (Jin et al., 1996). É possível o melhoramento genético da cultura da pimentado-reino para resistência contra a doença fusariose através de mutagênese associada àtecnologia in vitro. 


\section{REVISÃO DE LITERATURA}

\subsection{Cultura de pimenta-do-reino}

\subsubsection{Considerações gerais}

A pimenta-do-reino (Piper nigrum L.) é uma planta originária da Índia, na região submontanhosa do "Ghats" Ocidental, pertencente à família Piperaceae e ao gênero Piper, que apresenta várias espécies. Dentre essas espécies, a espécie Piper

nigrum é a mais importante, apresentando tanto variedades selvagens quanto cultivadas.

O estudo de cariótipo é um importante campo de pesquisa para entendimento das inter-relações e direções evolutivas. Os estudos realizados por Mathew (1974) quanto ao número de cromossomos de variedades da espécie $P$. nigrum apresentou uma variação de 52 a 104 cromossomos: $2 n=52$ para as variedades cultivadas (Aripadappan, Kuthiravally, Kumbhakodi, Kottanadan, Narayakodi e Karimunda) e $2 n=52$ ou $2 n=104$ para as variedades selvagens (seis, das quais duas com 104 cromossomos). A ausência de espécies de Piper com $2 n=26$ sugere que o número mínimo de 52 cromossomos seja o básico diplóide das variedades de Piper nigrum.

Há variações quanto ao número de cromossomos das espécies do gênero Piper. Estudos anteriores indicaram, para a espécie Piper subpeltatum número, diplóide igual a 24 cromossomos (Johansen, 1931), e 24 cromossomos para $P$. chaba, 24, 96 e 148 para $P$. longum, 28 para $P$. geniculatum, $P$. unguiculatum e $P$. medim, 32 e 64 para $P$. betle, 80 para $P$. ornatum e 48 e 128 cromossomos para $P$. nigrum (Sharma \& Bhattacharyya, 1959). Ademais, Dasgupta \& Datta (1976) observaram para 64 cromossomos para $P$. betle, 24 para $P$. cubeba, 48 para $P$. longum, 24 para $P$. magnificum, 36 para $P$. nigrum L. Agartala e 60 cromossomos para $P$. nigrum L. South Índia. É evidente que o número de cromossomos é muito variável nesta família e, embora cerca de 2.000 espécies sejam registradas, somente 64 espécies têm número 
de cromossomos relatado na literatura e ocorrem números múltiplos de 8, 11, 12, 13 e 14. Aproximadamente $47,3 \%$ das espécies de Piper têm $x=12$ e somente $19,04 \%$ têm $x=13$. Alteração no número de cromossomo em evolução parece muito natural no gênero Piper, por ocorrência de biotipos cromossômicos em muitas espécies, originados a partir de células aneussomáticas ou aneuploidia meiótica ou partenogênese (Dasgupta \& Datta, 1976).

A planta é considerada autógama, cuja floração nas condições climáticas da Amazônia ocorre de novembro a abril, na estação de maior ocorrência de chuvas. A inflorescência é uma espiga pendulosa de 5 a $20 \mathrm{~cm}$ de comprimento com 70 a 100 floretas hermafroditas, com dois estames dispostos lateralmente ao ovário e ao estigma. A polinização natural é por geitonogamia através da dispersão do pólen por gotículas d'água, orvalho ou chuva, cuja formação do fruto dá-se seis meses após a polinização (Figura 1a-c), (Poltronieri et al., 1999).

A biologia floral, de plantas da coleção de germoplasma da Estação de Pesquisa em Pimenta-do-reino em Kerala, Índia, é caracterizada por ser muito variável, quanto a flores masculinas, femininas e hermafroditas na espiga, a seqüência de abertura das flores, e a duração da deiscência de antera e da receptividade do estigma na espiga, havendo grande influência dos fatores ambientais. A maioria das cultivares é hermafrodita, com algumas poucas exceções femininas, e os tipos selvagens são geralmente dióicos, mas freqüentemente são encontrados tipos com flores hermafroditas (Nambiar et al., 1978).

No Brasil, a pimenta-do-reino (Piper nigrum L.) foi introduzida no Estado da Bahia no século XVII e posteriormente, levada para os Estados da Paraíba, Maranhão e Pará, cuja produção era insignificante, restrita a fundos de quintais (Albuquerque \& Condurú, 1971).

Imigrantes japoneses, em 1933, passando pelo porto de Singapura trouxeram para o Brasil algumas estacas de pimenta-do-reino, cultivar Kuching que no Brasil denominou-se Cingapura, e introduziram no Município de Tomé-Açu, Estado do Pará, onde teve início a produção comercial, principalmente de pimenta preta e pimenta branca (Figura de). Devido ao alto lucro, principalmente no período pós-guerra nas décadas de 40 e 50, a cultura foi rapidamente difundida no Estado do Pará através da propagação vegetativa (Ando et al., 1997). 
É uma cultura que se desenvolve muito bem em clima quente e úmido, com precipitação pluviométrica média de $2.500 \mathrm{~mm} / \mathrm{ano}$, umidade acima de $80 \%$ e temperatura média em torno de $23^{\circ} \mathrm{C}$ a $28^{\circ} \mathrm{C}$, e em solos com boa drenagem, estas condições são encontradas na região norte do Brasil (Albuquerque et al., 1989).

\subsubsection{Importância sócio-econômica no Brasil}

O Brasil tornou-se um dos maiores produtores e exportadores de pimenta-doreino no mundo. Em 1995, a pimenta-do-reino gerou um volume de divisas para o País da ordem de US\$51.890.476,00. O Estado do Pará foi o maior produtor e exportador brasileiro em 1995, e a pimenta-do-reino foi a cultura mais importante para o Estado, gerando US $\$ 49.061 .718,00$ (cerca de 95\% do total exportado) (Santana et al., 1997).

A produção a partir de 1991, que era de 83.700 t, teve uma redução para 31.900 t em 1997, mas vem se recuperando e, em 2.000, foram produzidas $45.500 \mathrm{t}$. A área colhida que foi de 36.800 ha em 1991 e que se reduziu para 11.200 ha em 1988, alcançou em 2000, 15.900 ha, sendo a produtividade média neste ano $2.868 \mathrm{~kg} / \mathrm{ha}$. Anualmente são exportadas mais de $50 \%$ da produção, tendo como principais países importadores os Estados Unidos, Alemanha, Países Baixos e Argentina. O Estado do Pará é o principal produtor brasileiro com cerca de $90 \%$ da produção, seguido pelo Espírito Santo e Bahia (Anexo A).

Os principais países produtores, considerando média de cinco anos, são Índia, Indonésia, Brasil e Malásia, variando de média de 56.000 t (Índia) a 16.920 t (Malásia) anuais e também exportadores, com divisas superior a US\$ 86 milhões de dólares para a Indonésia (42.600 t), seguida pela Índia e Brasil (21.494 t) com cerca de mais de US\$36,5 milhões de dólares de média anual (Anexo B).

O consumo de pimenta-do-reino no Brasil é de cerca de 5.000 t. anual, sendo a maior parte da produção exportada, cuja tonelada no mercado internacional já alcançou mais de US\$ $3.400,00$ para pimenta preta e US\$ $5.000,00$ para pimenta branca (Anexos C e D).

\subsubsection{Métodos de propagação}

A propagação é realizada tanto por sementes quanto através de estacas vegetativas. A propagação por sementes é adotada basicamente em programas de melhoramento enquanto por estacas é a forma tradicional de produção de mudas para 
plantios comerciais. A viabilidade da semente é perdida rapidamente após 40-50 dias de armazenamento e a germinação ocorre desde os 15 aos 90 dias após semeadura, dependendo de cultivares e condições ambientais (Nambiar et al., 1978).

A propagação vegetativa é realizada a partir de estacas, retiradas de um terço médio da planta, com um nó, sendo mais apropriada para a produção de mudas, estacas com dois nós. No Brasil, é tradicionalmente utilizada para plantios comerciais, mudas a partir de estacas de plantas com dois a quatro anos (Albuquerque et al., 1989).

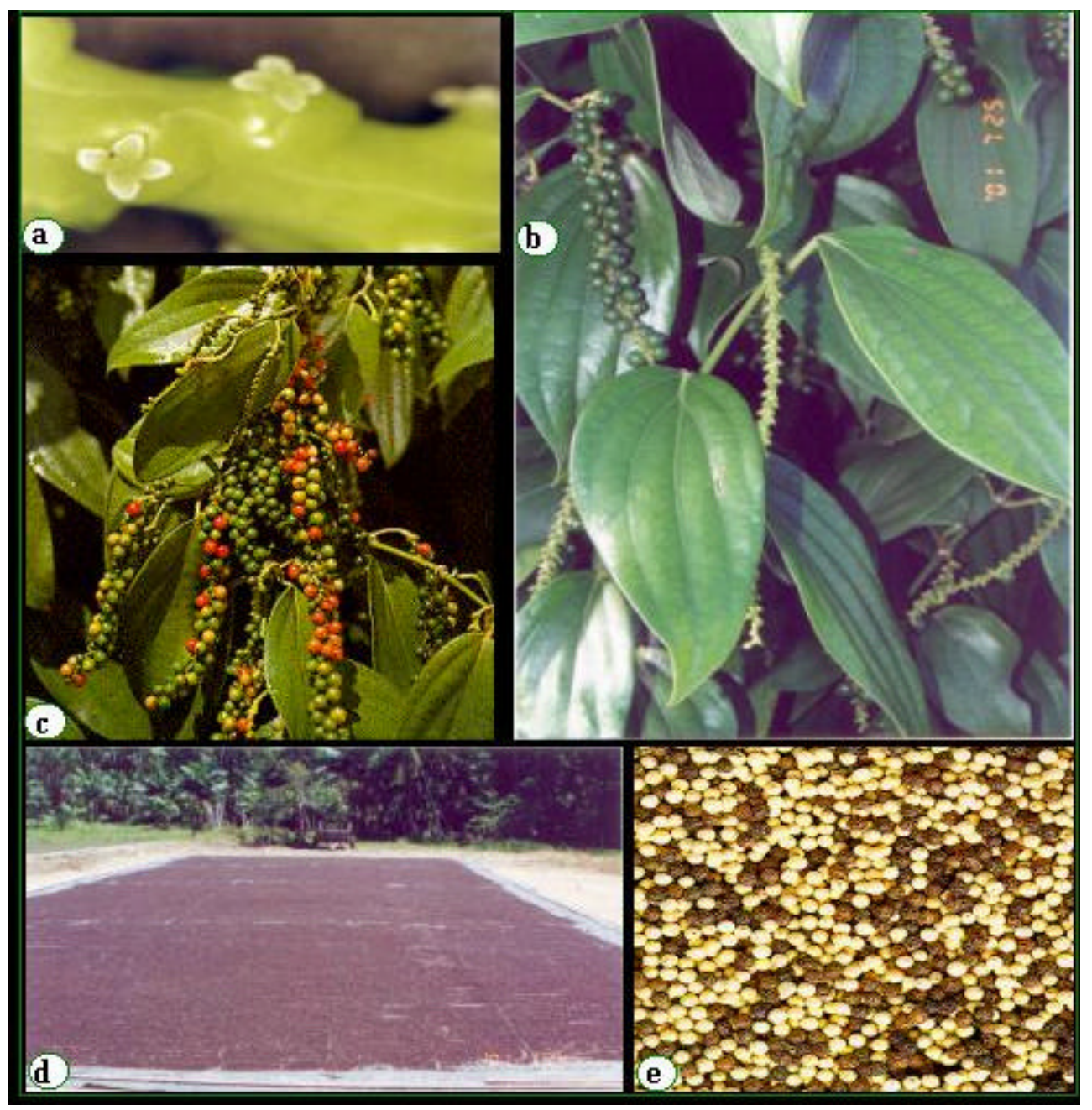

Figura 1 - Características gerais da cultura.

a) Inflorescência do tipo espiga;

b) Desenvolvimento dos frutos

c) Frutos maduros e em estádio de colheita

d) Produção de pimenta preta através da secagem a pleno sol

e) Pimenta preta e pimenta branca pronta para comercialização 


\subsubsection{A doença fusariose}

Em decorrência da estreita base genética e, provavelmente, associado com outros fatores, o desenvolvimento da cultura de pimenta-do-reino tem sido limitado pela doença conhecida como fusariose. Esta provoca podridão das raízes e secamento dos ramos, causado pelo fungo Nectria haematococca f. sp. piperis (Fusarium solani f. sp. piperis) que se disseminou rapidamente na região, destruindo, em curto espaço de tempo, grandes áreas cultivadas com pimenta-do-reino (Albuquerque \& Duarte, 1977).

Os primeiros sintomas desta doença foram observados a partir de 1960, através do amarelecimento das folhas, queda gradativa das folhas e entrenós, e morte das plantas, causada pela infecção das raízes. As condições de temperatura e umidade elevadas da região favoreceram a esporulação do patógeno nas hastes das plantas mortas, e a partir de 1970, devido àdisseminação aérea dos esporos passou a ocorrer a infecção dos ramos das plantas, agravando ainda mais a doença (Duarte \& Albuquerque, 1999).

O fungo Nectria haematococca Berk \& Br. f. sp. piperis Albuq. é um ascomiceto pertencente à ordem Hypocreales, família Nectriaceae, produzindo peritécios redondos ou piriformes, avermelhados, com superfície rugosa e consistência gelatinosa. O anamórfico é classificado como Fusarium solani (Mart.) Sacc. f. sp. piperis Albuq., um hifomiceto da ordem Tuberculariales, família Tuberculariaceae que produz três tipos de esporos, os microconídios, macroconídios e os conídios intermediários, formados em conidióforos, cujos esporos de resistência, os clamidósporos, podem se originar do espessamento de paredes das células das hifas ou de macroconídios (Duarte \& Albuquerque, 1999).

Segundo Albuquerque \& Ferraz (1976), devido à ocorrência de doenças severas, entre as quais a fusariose, e ao aumento dos preços de insumos e mão-deobra, o custo de produção no Brasil tornou-se muito elevado. Para compensar economicamente o produto final para exportação, é necessário desenvolver tecnologias visando o aumento da produtividade ou da lucratividade. Para tanto, Albuquerque \& Duarte (1991) consideram que a obtenção de cultivares mais produtivas, com características de tolerância àfusariose, é indispensável para que o Brasil continue a concorrer no mercado internacional

A fusariose no Estado do Pará é um dos problemas mais sérios para a cultura tendo concorrido para a redução da área cultivada e da produtividade. $\mathrm{O}$ aumento da 
variabilidade genética da pimenta-do-reino poderá possibilitar o desenvolvimento de novos sistemas de produção (Albuquerque et al., 1997).

Algumas espécies nativas da Amazônia do gênero Piper foram testadas quanto à resistência a doença fusariose através de inoculações artificiais. Os resultados indicaram níveis satisfatórios de tolerância para as espécies de Piper aduncum Linn., Piper colubrinum Link., Piper tuberculatum Jacq., P. hispidinervium C. D. C. e $P$. hispidum Sw que podem ser utilizadas como fonte de resistência (Poltronieri et. al., 1999).

\subsection{Aplicação das técnicas in vitro}

Nas últimas décadas, as técnicas de cultura in vitro de tecidos e de biologia molecular passaram a ter grande significância em todas as áreas da biologia pura e aplicada. Suas aplicações na área vegetal têm sido na micropropagação em massa, multiplicação rápida de genótipos superiores, limpeza clonal, cultura de antera, variação somaclonal, mutagênese, eficiência de mutação e seleção, conservação e intercâmbio de germoplasma, produção de sementes artificiais, clonagem de genes e obtenção de plantas transgênicas de espécies de importância na agricultura e indústria. Estes aspectos acabaram por mudar os rumos da pesquisa, pois os métodos in vitro passaram a constituir elementos importantes na exploração e entendimentos de novas técnicas para melhoramento de muitas culturas, principalmente daquelas cujos problemas não podem ser solucionados via melhoramento convencional, por si só (Nitzsch, 1983; Krikorian, 1990).

A conservação de germoplasma tem sido reconhecida como uma forma vital para o melhoramento de plantas, pois assegura a disponibilidade de germoplasma proveitoso em qualquer tempo e evita o processo de erosão genética (Roca, 1984). A conservação in vitro é, particularmente, importante para espécies de propagação vegetativa e espécies que apresentam sementes recalcitrantes. As plantas conservadas em campo, além dos elevados custos, correm riscos de perdas de

genótipos valiosos devido à ocorrência de pragas, doenças e outros fatores de estresses ambientais $(\mathrm{Ng} \& \mathrm{Ng}, 1991)$. A conservação in vitro por cultivo mínimo 
oferece uma solução imediata para manutenção a curto e médio prazo, enquanto a criopreservação é uma solução para conservação em longo prazo (Stanwood, 1985).

A cultura de embrião, uma outra aplicação das técnicas de cultura de tecidos, permite recuperar híbridos raros de cruzamentos incompatíveis, superar dormência e esterilidade de sementes, estudar os aspectos nutricionais e fisiológicos do desenvolvimento do embrião, desenvolver métodos de micropropagação, e testar viabilidade de sementes (Hu \& Ferreira, 1990).

Ademais, a cultura de tecidos gera variação genética, denominada variação somaclonal, similar àquelas originadas por mutagênicos químicos e físicos, que podem ser incorporadas em programas de melhoramento genético. Através da seleção in vitro, mutantes com tolerância a fatores abióticos e resistência a doenças podem ser isolados em curto período de tempo e pode complementar a seleção em campo. O uso de marcadores moleculares tais como RAPD ("Random Amplified Polymorphic DNA"), RFLP ("Restriction Fragment Length Polymorphism), AFLP (“Amplified Fragment Length Polymorphism") e microsatélites são ideais para identificar somaclone genético de epigenético (Jain, 2001).

As técnicas de cultura de células e tecidos permitem a regeneração de plantas tanto através da formação de gemas caulinares (organogênese) quanto de embriões somáticos (embriogênese). Essas duas vias de regeneração de plantas, organogênese e embriogênese, podem ser de origem uni ou multicelular, diretamente a partir de células do tecido original ou indiretamente via formação de calos. As diferenças entre ambas são anatômicas, sendo a gema uma estrutura monopolar com ampla conexão vascular com o tecido do explante enquanto o embrião somático é uma estrutura bipolar sem conexão com o explante através da vascularização (Vieira e Apezzato-da-Glória, 2001).

\subsubsection{Micropropagação}

A propagação in vitro de plantas tem despertado grande interesse, seja pela produção de plantas livres de patógenos e de material de elite, ou pela produção de mudas em grande escala em curto tempo. A micropropagação de bananeira, segundo vários autores, tem sido possível através do uso de ápice caulinar ou ápice floral em meio MS contendo 6-benzilamino purina (BAP 2,0 a 5,0 mg. $\mathrm{L}^{-1}$ ) combinado ou não com auxina (IAA), numa taxa de indução média de brotos que varia de 2 a 9 brotos por 
explante, dependendo da cultivar, os quais são com sucesso enraizados em meio de cultura com diferentes reguladores de crescimento (Cronauer \& Krikorian, 1984; Vuylsteke \& De Langhe, 1985; Banerjee \& De Langhe, 1985).

Robinson et al. (1993) avaliaram o desempenho de bananeira, em três ciclos de produção, a partir de mudas provenientes de cultura de tecidos e via método convencional, e verificaram que plantas originárias de cultura de tecidos apresentaram maior produção e menor tempo do ciclo para colheita, principalmente no primeiro ciclo que alcançou índice de produção 20,4\% (56 tha ${ }^{-1} \cdot a^{-1} o^{-1}$ ) superior às plantas provenientes de mudas convencionais.

Em pimenta-do-reino (Piper nigrum), Mathews \& Rao (1984), ao estudarem respostas in vitro de diferentes explantes, verificaram que a maioria desses explantes (segmentos de hipocótilo, gemas axilares, ápice caulinar) permitiu a formação de calos em meio de cultura contendo uma larga combinação de auxina-citocinina, com exceção de segmentos de folha e tecido de antera. Além disso, observaram que ápices caulinares provenientes de plântulas in vitro diferenciaram múltiplas brotações em meio MS contendo IAA e BA (1 $\mathrm{mg}^{-1}{ }^{-1}$ de cada) e enraizaram em meio com metade da concentração de MS com 0,2 mg..$^{-1}$ de NAA.

Khoon \& Talib (1985), ao testarem o uso de ácido naftalenoacético (NAA) e de duas substâncias fenólicas (phloroglucinol ou phloridzin) para enraizamento in vitro de brotos de pimenta-do-reino, verificaram que não houve influencia dessas substâncias fenólicas no enraizamento e que NAA $\left(0,1 \mathrm{mg.l.}^{-1}\right)$ induz maior número e tamanho de raízes em comparação com meio de cultura sem NAA.

Estudos realizados por Philip et al. (1992) em pimenta-do-reino permitiram, nos melhores tratamentos, uma média de 25 novos brotos por meristema caulinar após 3-4 subcultivos, com intervalo de 30 dias por subcultivo, o que, segundo o protocolo sugerido pelos autores, permitiria uma produção estimada de 15.000 plantas a partir de um explante por ano, quando comparado com apenas 50 estacas enraizadas por planta por ano, convencionalmente obtidas por propagação vegetativa. Ressalte-se que, nesse estudo, um ponto limitante foi o problema de contaminação por bactérias endógenas apresentado pelos explantes provenientes de plantas adultas.

Saxena e Dhawan (1999) descreveram um protocolo eficiente e reproduzível para propagação em larga escala de bambu (Dendrocalamus strictus Nees) através de embriogênese somática. Este protocolo apresenta a indução de calos embriogênicos 
na extremidade das sementes em meio de cultura MS suplementado com 2,4-D (30 $\mu \mathrm{M})$; proliferação de embriões somáticos em meio de cultura MS com adição de polivinilpirrolidona solúvel (PVP a $\left.250 \mathrm{mg}^{-L^{-1}}\right)$ e 2,4-D (10 $\left.\mu \mathrm{M}\right)$ combinado com cinetina $(5 \mu \mathrm{M})$ e IBA $(2 \mu \mathrm{M})$ ou combinado com BAP $(10 \mu \mathrm{M})$ que, transferidos para mesmo meio de cultura mas com NAA $(5 \mu \mathrm{M})$ e cinetina $(5 \mu \mathrm{M})$, converteu-se em plântulas. Mais de 100.000 plantas foram produzidas a partir deste protocolo.

Árvores de Eucalyptus tereticornis de quatro anos de idade foram micropropagadas a partir de gemas axilares introduzidas em meio de cultura MS modificado, apresentando melhor performance para proliferação de brotos com adição de $\operatorname{BAP}\left(0,5\right.$ ou $\left.1,0 \mathrm{mg} \cdot \mathrm{L}^{-1}\right)$ e IAA $\left(0,1 \mathrm{mg} \cdot \mathrm{L}^{-1}\right)$, sendo o agente solidificante, Phytagel, mais apropriado ao alongamento dos brotos, porém favorável à vitrificação, em contraste com agar. $\mathrm{O}$ uso de cloreto de cálcio di-hidratado $\left(\mathrm{CaCl}_{2} \cdot 2 \mathrm{H}_{2} \mathrm{O}\right.$ a $\left.880 \mathrm{mg} \cdot \mathrm{L}^{-1}\right)$ reduziu a vitrificação e induziu o alongamento dos brotos, os quais foram enraizados com sucesso em meio de cultura MS com metade da concentração dos sais e 1,0 mg. $\mathrm{L}^{-1}$ de IBA. Após aclimatação, as mudas formadas foram cultivadas no campo apresentando uma taxa de sobrevivência de 84 a 100\% (Sharma \& Ramamurthy, 2000).

\subsubsection{Regeneração de plantas via organogênese}

Programa de melhoramento genético cujo objetivo é a produção de triplóides tem sido facilitado e menos tedioso através da cultura de tecidos. Plantas triplóides de amoreira (Morus Alba L.) foram regeneradas a partir de cultura de endosperma imaturo, cujas melhores condições foram em meio de cultura MS suplementado com 5 $\mu \mathrm{M}$ de 2,4-D para indução de calos e em meio de cultura contendo $1 \mu \mathrm{M}$ de "thidiazuron" (TDZ) ou $5 \mu \mathrm{M}$ de BAP e $1 \mu \mathrm{M}$ de NAA quando os calos foram cultivados para produção de brotos. Os brotos obtidos foram multiplicados em $5 \mu \mathrm{M}$ de BAP e enraizados em metade da concentração dos sais de MS contendo $7 \mu \mathrm{M}$ de IBA, sendo transferidos para solo apresentando sobrevivência de $71 \%$. As análises citológicas das plantas sobreviventes confirmaram a origem das plantas de tecido triplóide com $3 n$ igual a 42 cromossomos (Thomas et al., 2000).

Eficiente sistema de regeneração para plantas de maçã foi estabelecido por Caboni et al. (2000) via organogênese. Os calos foram induzidos a partir de ápices 
caulinares de plantas in vitro em meio de cultura MS sem glicina, suplementado com BA $(17,8 \mu \mathrm{M})$, NAA $(2,7 \mu \mathrm{M})$ e $250 \mathrm{mg} . \mathrm{L}^{-1}$ de "cefotaxime" por 20 dias no escuro, que transferidos para mesmo meio de cultura sem auxina (NAA) e sob luz (fotoperíodo de 16h) originaram brotos a partir de 15 dias, que foram multiplicados, enraizados e estabelecidos com sucesso em solo.

Murch et al. (2000) estabeleceram um sistema rápido e eficiente de regeneração de plantas de Hypericum perforatum cv 'Anthos' (planta medicinal) via organogênese. Obtiveram ótima proliferação de brotos em segmentos de hipocótilo de plântulas obtidas in vitro ao empregaram "thidiazuron" (5 $\mu \mathrm{M})$ em meio de cultura contendo sais de MS e vitaminas de meio básico B5 nos primeiros 9 dias de cultivo e nos seguintes 9 dias sem "thidiazuron". Posteriormente, os brotos transferidos para meio de cultura líquido ou semi-sólido com metade da concentração dos sais e das vitaminas sem regulador de crescimento originaram "plantlets" viáveis em cerca de dois meses.

\subsubsection{Regeneração de plantas via embriogênese somática}

Em pimenta-do-reino, a regeneração de plantas via embriogênese somática foi conseguida por Joseph et al. (1996). Os calos foram induzidos a partir de embriões zigóticos em meio básico $\mathrm{SH}$ sólido ou líquido e sem regulador de crescimento ou com adição de 2,4-D (0,5 a 5,0 mg. $\left.\mathrm{L}^{-1}\right)$. Os embriões somáticos originados a partir dos calos germinaram em meio líquido ou sólido com metade da concentração de sais de $\mathrm{SH}$, sem reguladores de crescimento e nível de sacarose reduzido de 3\% para 1,5\%. A germinação dos embriões somáticos ocorreu após oito meses de cultivo em meio de cultura estático e em oito semanas em cultura de suspensão, e as plantas regeneradas foram estabelecidas em solo.

Um protocolo eficiente e rápido de regeneração de plantas de quatro espécies de Medicago spp via embriogênese somática direta, sem passagem pela fase de calos, foi estabelecido por lantcheva et al. (1999) a partir de segmento de hipocótilo, cotilédones e base do pecíolo. Os autores observaram o desenvolvimento de embriões somáticos após 20 dias de cultivo e regeneração completa em 35 a 40 dias, utilizando meio de cultura MS suplementado com "thidiazuron" $(0,91$ a $4,54 \mu \mathrm{M})$ ou BAP $(0,88$ a 
4,44 $\mu \mathrm{M})$. Obtiveram uma alta freqüência de embriões somáticos, com indução de embriões somáticos secundários na superfície dos embriões primários.

Oldach et al. (2001) estabeleceram eficientes sistemas para regeneração in vitro de plantas de milheto [Pennisetum glaucum (L.) R. Br.] e sorgo [Sorghum bicolor (L.) Moench] a partir de embriões zigóticos imaturos. Cultivaram em meio básico de cultura L3 (indicado para cultura recalcitrante) suplementado com 2,4-D (2,5 mg. $\left.\mathrm{L}^{-1}\right)$, BAP $\left(0,1 \mathrm{mg} \cdot \mathrm{L}^{-1}\right)$ e nitrato de prata (especificamente para milheto a $\left.5,0 \mathrm{mg} \cdot \mathrm{L}^{-1}\right)$, para indução de calos embriogênicos, e observaram desenvolvimento de embriões somáticos que se converteram em plântulas quando transferidos para mesmo meio de cultura mas com adição de somente BAP $\left(1,0 \mathrm{mg} \cdot \mathrm{L}^{-1}\right)$. A formação de raízes foi melhorada em meio de cultura contendo metade da concentração de sais de L3 sem regulador de crescimento. O tempo para produção de plantas desde a indução de calos foi de 9 a 14 semanas para sorgo e de 9 a 20 semanas para milheto.

A embriogênese somática é considerada um método de grande potencial para propagação em massa de espécies coníferas. Arya et al. (2000) testaram diferentes meios de cultura e estádios de desenvolvimento de embriões zigóticos para indução de calos embriogênicos em Pinus roxburghii Sarg.. Resultados promissores foram obtidos a partir de embriões zigóticos no estádio pré-cotiledonar (0,5 - 1,2 mm), em meio de cultura DCR ("Douglas fir Cotyledon Revised medium") suplementado com $10 \mu \mathrm{M}$ 2,4-D + $5 \mu \mathrm{M}$ BA e $500 \mathrm{mg} \cdot \mathrm{L}^{-1}$ de caseína hidrolisada, para indução de calos embriogênicos (4 a 5 semanas). Foram desenvolvidos embriões somáticos ao estádio II, mas regeneração de plantas não foi reportada.

Regeneração de plantas de Acacia mangium via embriogênese somática foi obtida por Xie \& Hong (2001), a partir de calos embriogênicos originados de embriões zigóticos imaturos em meio de cultura MS, contendo TDZ (1 a $\left.2 \mathrm{mg}^{-\mathrm{L}^{-1}}\right), \operatorname{IAA}(0,25 \mathrm{a}$ 2,0 mg. $\left.\mathrm{L}^{-1}\right)$ e uma mistura de aminoácidos. Para o desenvolvimento dos embriões somáticos, do estádio globular ao cotiledonar, foram utilizados meios de cultura com a metade dos sais de $\mathrm{MS}, \mathrm{GA}_{3}$ (2,5 a 5,0 mg.L mg.L-1 $)$, carvão ativado $(0,1 \%)$ e concentração elevada de sacarose $(5,0 \%)$, onde os embriões germinaram e converteram-se em plântulas que foram transferidas para solo. $O$ processo foi desenvolvido num período de cerca de 8 meses, desde a indução de calos à transferência das plântulas para solo. Em batata, embriões somáticos foram obtidos a 
partir de diferentes explantes cultivados in vitro (segmentos de entrenós, folhas e raízes) em meio MS, contendo IAA $(19 \mu \mathrm{M})$ e TDZ ou BAP a 0,15 $\mu \mathrm{M}$ para indução de calos (início 7 a 14 dias), e contendo zeatina $(12 \mu \mathrm{M})$, IAA $(0,05 \mu \mathrm{M})$ e $\mathrm{GA}_{3}(0,55 \mu \mathrm{M})$ para indução de embriões somáticos (início 2 a 3 semanas), cuja conversão dos embriões em plântulas ocorreu em 2 a 4 semanas em meio básico MS sem regulador de crescimento (Seabrook \& Douglass, 2001).

Explantes do tipo segmento de folha e entrenó, obtidos de plântulas in vitro de carvalho (Quercus robur L.), induziram resposta embriogênica indireta quando cultivados, inicialmente, por 6 semanas em meio de cultura contendo $4 \mathrm{mg} \cdot \mathrm{L}^{-1}$ de NAA e diferentes concentrações de $\operatorname{BAP}\left(0,5\right.$ a 2 mg. $\left.\mathrm{L}^{-1}\right)$; depois por 4 semanas em meio básico de cultura MS suplementado com BAP e NAA a 0,1 mg. $\mathrm{L}^{-1}$ de ambos e em seguida em meio de cultura livre de regulador de crescimento, sendo que os embriões somáticos se originaram da superfície dos calos. Houve problemas na conversão dos embriões somáticos a plântulas, sendo contornados através de tratamento de maturação dos embriões com ABA e osmótico (sorbitol e sacarose), e através da transferência dos embriões com 5 a $10 \mathrm{~mm}$ para meio de germinação com $8 \%$ de sacarose e 2,7 mg. $\mathrm{L}^{-1}$ de ABA (Cuenca et al., 1999).

Mesmos tipos de explantes, segmentos de folha e entrenó, foram utilizados por Kintzios et al. (1999) no processo de embriogênese somática em rosa (Rose sp.), mas somente a partir de folhas se obteve sucesso e houve diferença quanto àresposta dos diferentes genótipos. Embriões somáticos foram induzidos em meio de cultura MS com $\rho$-ácido clorofenoxiacético $(53,5 \mu \mathrm{M})$ e cinetina $(4,6 \mu \mathrm{M})$, e a maturação e a germinação dos embriões com diferentes estádios de desenvolvimento foram conduzidas em mesmo meio de cultura suplementado com BAP $(5,2 \mu \mathrm{M})$ e IAA $(5,7$ $\mu \mathrm{M})$, cujas plântulas regeneradas apresentando três a quatro folhas foram transferidas para casa de vegetação. O protocolo foi estabelecido através de 4 períodos de cultivos sucessivos, num total de 16 semanas a partir do início da cultura.

Embriogênese somática direta em orquídea do gênero Oncidium foi observada por Chen et al. (1999) a partir de folhas, como explantes, em 1/1/MS com 0,3 a $1 \mathrm{mg} \cdot \mathrm{L}^{-1}$ de TDZ, cujas células do mesofilo e epiderme se diferenciaram em embriões somáticos, que germinaram e se converteram em plântulas. 
Biahoua e Bonneau (1999), ao estudarem a influência e a função de tipos e concentrações de açúcares no processo de embriogênese somática em embriões zigóticos de Euonymus europeus L., uma angiosperma lenhosa, observaram que a concentração de $350 \mathrm{mM}$ de sacarose ou $89 \mathrm{mM}$ de glicose, em meio de cultura embriogênico para a espécie, proporcionou alta freqüência de embriões somáticos, acima de 50 e 24 por explante, respectivamente. Esta resposta foi contrastante, pois, em maior concentração de sacarose $(350 \mathrm{mM})$, a resposta embriogênica foi mais favorável, sendo 6 vezes maior que o sistema original, enquanto para glicose na menor concentração $(89 \mathrm{mM})$. Isto deve estar ligado ao aumento da concentração de nutrientes e do potencial osmótico no meio de cultura quanto ao uso de sacarose. Uma concentração mínima de açúcar é requerida para induzir calos e embriogênese somática, e um potencial osmótico mínimo é necessário para a emergência de embriões somáticos.

\subsection{Métodos de melhoramento genético em plantas}

Os programas de melhoramento tanto convencional como não convencional consistem na produção de variabilidade genética na população seguida pela seleção dos genótipos desejáveis (Wenzel, 1985). A maioria da variabilidade genética disponível utilizada tem ocorrido naturalmente e bancos de germoplasma existem para preservar esta variabilidade. Os cruzamentos permitem a produção de novas e desejáveis recombinações de genes. Quando o banco de germoplasma não dá suporte à recombinação gênica desejável e como as mutações espontâneas desejáveis ocorrem em extrema baixa freqüência, o uso das técnicas de indução de mutação é uma alternativa promissora, pois permitem a geração da variabilidade genética, e tem acelerado o sucesso no melhoramento de espécies cultivadas (Maluszynski et al., 1995).

Portanto, a variabilidade genética é essencial ao melhorista por permitir selecionar cultivares de plantas, as quais são, por exemplo:
a) mais adaptadas às mudanças ambientais;
b) mais eficientes na utilização de nutrientes;
c) mais tolerantes a pragas e doenças; $\mathrm{e}$ 
d) mais produtivas e de melhor qualidade.

A seleção é a força direcional dos melhoristas de plantas para identificar, dentro de uma população variável, os melhores genótipos que respondem ঝे demandas de produtores agrícolas, da agroindústria e dos consumidores. A hibridação, a recombinação e a mutação tanto espontânea quanto induzida se constituem os fatores mais importantes na geração de variabilidade em plantas (Donini \& Sonnino, 1998).

O controle da disseminação de doença de fungo tem sido realizado através de técnicas agrícolas, como rotação de cultura, não uso de solo infectado e de materiais de plantas infectadas, aplicação de agroquímicos e melhoramento genético de cultivares resistentes a fungos. A aplicação de agroquímicos tem sido uma alternativa no controle, mas apresenta um custo elevado, torna-se ineficiente com a evolução do patógeno e causa danos ao meio ambiente. Diante disso, o melhoramento genético é o mais apropriado, pois os custos de produção são menores e não afetam o ambiente (Cornelissen \& Melchers, 1993).

O uso da cultura de tecidos e células in vitro no melhoramento para resistência a doença tem como vantagens mais importantes: a) tornar mais fáceis as medidas de pequenas diferenças quantitativas em resistência herdadas poligenicamente (horizontal ou geral), pois os efeitos de clima e condições ambientais são controlados; b) possibilitar a manipulação de grandes populações de indivíduos em espaço muito pequeno; e c) capacitar trabalhos com micrósporos e haplóides, os genomas mais simples, que permitem a descoberta de características recessivas e caracteres aditivos dentro de populações relativamente pequenas. Essas vantagens associadas aos procedimentos de melhoramento clássico aceleram a produção de uma nova variedade (Wenzel, 1985). A aplicação prática mais antiga da cultura de tecidos para controle de doenças é a propagação de plantas livres de patógenos através da cultura de meristemas.

\subsubsection{Métodos convencionais}

Um programa de melhoramento convencional tem três estágios: a criação da variação, a seleção de variantes benéficos e ensaios em campo para confirmar os variantes selecionados (Cassels, 1998). 
Os programas de melhoramento genético da cultura de pimenta-do-reino no Brasil, através de métodos convencionais para obtenção de genótipos com resistência ou tolerância à doença fusariose, têm apresentado pouco progresso. Os acessos disponíveis de Piper nigrum no banco de germoplasma são susceptíveis à doença fusariose e as espécies de Piper nativas tolerantes têm sido pouco empregadas em cruzamentos interespecíficos. O programa de melhoramento da Embrapa Amazônia Oriental, Belém, Pará, prevê a introdução de novos acessos do centro de origem ao banco de germoplasma e estabelece o emprego de métodos de melhoramento através da hibridação intraespecífica e interespecífica, e de indução de mutação com auxílio das técnicas de cultura de tecidos (Poltronieri et al., 1999).

Um programa de hibridação entre quatro parentais de pimenta-do-reino conduzido na Índia deu origem ao primeiro híbrido cultivado comercialmente. A combinação entre as cultivares "Uthirankotta" $x$ "Taliparamba-1" ("Cheriyakaniayakkadan") produziu 69 sementes, das quais 14 plantas $F_{1}$ sobreviveram e uma delas apresentou comprimento de espiga médio de $10 \mathrm{~cm}$ com 82 flores por espiga e $82 \%$ de frutificação. Este híbrido foi multiplicado e apresentou performance superior em todas as características quando comparado à cultivares locais. Do início das hibridações ao lançamento em 1966 do híbrido denominado Panniyur-I decorreram 13 anos (Nambiar et al., 1978).

A pimenta-do-reino por se tratar de uma espécie que apresenta enorme grau de variação morfológica e visando auxiliar a escolha de parentais para os programas de melhoramento por hibridização quanto à divergência genética desejada, Mathew et al. (2001) estabeleceram dez grupos em 51 cultivares de P. nigrum a partir da análise de 27 caracteres morfológicos. Esta divergência genética entre os grupos ficou caracterizada quando analisaram o híbrido promissor obtido por hibridização entre as cultivares "Uthirankotta" e "Cheriyakaniayakkadan", as quais encontravam-se em grupos distantes.

Albuquerque et al.(1997), testando cultivares em áreas de ocorrência de fusariose em três municípios (Castanhal, Santa Izabel e Tomé-Açú) no Estado do Pará, concluíram que todas as cultivares testadas foram suscetíveis àdoença fusariose, com um aumento do índice da doença a partir do terceiro ano. Esses autores chamaram a atenção para o caráter produtividade elevada como não sendo a principal característica para a adoção de uma cultivar entre produtores de pimenta-do-reino, ressaltando que 
esta deve também apresentar tolerância àdoença fusariose e àseca, com maturidade precoce dos frutos e facilidade de propagação.

Poltronieri et al.(1997) obtiveram várias combinações de híbridos entre cultivares de Piper nigrum L., onde testaram através de inoculações artificiais os níveis de tolerância desses híbridos, chegando à conclusão que os híbridos obtidos não apresentavam tolerância àdoença fusariose.

\subsection{Métodos não convencionais}

\subsubsection{Indução de mutação}

Mutações são definidas como alterações herdáveis qualitativa e quantitativa de DNA não derivadas de segregação genética ou recombinação. Sabendo-se que as taxas de mutações espontâneas são muito baixas, as mutações induzidas têm sido mais utilizadas para aumentar as freqüências de mutações e variações, que podem ser induzidas tanto por tratamentos com mutagênicos químicos como substâncias alquilantes quanto físicos como radiações ionizantes (Predieri, 2001). As alterações no DNA nuclear ou de organelas citoplasmáticas resultam mutações em nível do gene, genoma ou cromossomo (deleções, inversões, translocações, duplicações, aneuplodias, quebras de ligação, etc.) que geram variabilidade, cuja limitação no melhoramento é a não especificidade da característica mutada (Tulmann Neto et al., 1998).

Os aspectos técnicos de melhoramento por mutação procedem com a escolha do mutagênico e dose; materiais iniciais e tamanhos da população; a manipulação do material tratado; e métodos apropriados de seleção dos mutantes. A dose ou concentração apropriada de mutagênicos tem que ser determinada antes da condução do método, porque existem diferenças em sensitividade das plantas a mutagênicos, que dependem dos fatores ambientais do material tratado (conteúdo de água, oxigênio, temperatura, etc.) e fatores biológicos (grau de ploidia, genótipos, etc.) (IAEA, 1977).

É sabido que o fator chave na irradiação de material vegetal é a dose, ou seja, a quantidade de energia de radiação absorvida pelo material medida em Gray (Gy). Considera-se três tipos de dose: alta ( $>10 \mathrm{kGy}$ ); média (1 a $10 \mathrm{kGy}$ ); e baixa ( $<1$ kGy). Doses altas são utilizadas para esterilização de alimentos e doses baixas (60 a 700 Gy) para indução de mutação em sementes, enquanto para material cultivados in 
vitro, a dose é muito menor, variando de 5 a 100 Gy, dependendo da espécie de planta, cultivar ou tipo de material inicial (Ahloowalia \& Maluszynski, 2001).

A radiação ionizante penetra no tecido e pode induzir grande número de diferentes tipos de alterações bioquímicas, ao nível de DNA, cromossomo e de genoma, incluindo aberrações cromossômicas tais como deleções, inversões, duplicações e translocações, e mutações gênicas. Raios-gama e raios-x têm sido os tipos de radiações ionizantes mais amplamente usadas, sendo a irradiação aguda (irradiação em curto período de tempo) a mais apropriada para mutagênese induzida em cultura de tecidos. O primeiro passo para o uso é a determinação da dose mais adequada a aplicar, baseada em testes de radiossensitividade através das respostas fisiológicas do material irradiado, quais sejam redução de $50 \%$ do crescimento vegetativo do material tratado $\left(\mathrm{GR}_{50}\right.$ dose que causa $50 \%$ de redução do crescimento) ou de sobrevivência ( $\mathrm{LD}_{50}$ dose que causa $50 \%$ de letalidade) quando comparado ao controle, no primeiro ciclo vegetativo após tratamento (vM1) (Predieri, 2001).

As mutações benéficas podem estar acompanhadas de efeitos colaterais desfavoráveis causados por ligações próximas a tais características ou efeitos pleiotrópicos que não podem ser corrigidos. A solução, neste caso, é induzir grande número de mutantes independentes para o tipo desejável e selecionar aqueles com menores níveis de efeitos colaterais indesejáveis. Preferencialmente, o material de planta para mutagênese deve ser geneticamente heterozigoto, pois a maioria das mutações é recessiva enquanto as dominantes raramente ocorrem. Muitos experimentos apresentaram melhores resultados a doses menores do que $L D_{50}$, pois dosagens mais baixas, apesar de apresentarem menores freqüências de mutações, têm a vantagem de causarem relativamente menos danos cromossômicos e outros efeitos laterais negativos (Przybyla, 1994).

Em experimentos com mutagênese, seja através de mutagênico químico ou físico, é necessário avançar o material tratado. Em plantas propagadas por sementes, mutantes recessivos são comumente selecionados a partir da segunda $\left(\mathrm{M}_{2}\right)$ ou terceira $\left(M_{3}\right)$ geração após tratamento, enquanto para aquelas propagadas vegetativamente são necessários vários ciclos para eliminar quimerismo e obter mutantes periclinais e sólidos. Em campo, pode necessitar vários anos, principalmente para plantas de ciclos longos, enquanto através de subcultivos in vitro, de $V_{2} a V_{4}$, estes mutantes poderão ser obtidos rapidamente, em questão de meses, e sem perdas de quaisquer genótipos 
sob condições livres de doença. Ademais, quando plantas mutantes são regeneradas via embriogênese somática a partir de cultura de células em suspensão, as chances são grandes de regenerantes serem mutantes sólidos, desde que pouco ou uma simples célula dê origem aos embriões (Ahloowalia \& Maluszynski, 2001).

Para plantas em que não há conhecida fonte genética para uma característica desejável, ou para plantas apomíticas ou estéril, em que a hibridação não é uma opção, a indução de mutações é o único método para melhoramento. Além dessas, para a maioria das plantas propagadas vegetativamente, as quais são altamente heterozigóticas e freqüentemente poliplóides ou aneuplóides, o melhoramento por indução de mutação oferece a vantagem de aumentar a freqüência de mutações (maioria recessiva) em uma ou poucas características, mantendo-se as principais características da variedade original (Tulmann Neto et al., 1998).

Nessas plantas propagadas vegetativamente, o evento de mutação induzida numa célula somática, de qualquer camada celular no meristema caulinar ou no primórdio de gema axilar, será transmitido e, eventualmente, expresso em descendentes somáticos (clones). Entretanto, um dos problemas sérios é a ocorrência de quimerismo quando gemas ou ápices caulinares, que apresentam camadas autônomas de células, são tratados com mutagênico. A célula mutada se desenvolverá numa quimera setorial ou mericlinal através de divisões celular e competição com células não mutadas. A situação desejada, considerando que a quimera setorial ou mericlinal é instável, é formar órgão completamente uniforme mutado, "homohistont", ou uma quimera periclinal através do crescimento e propagação clonal, pois as plantas serão completamente mutadas ou todas as células dentro de uma ou duas camadas serão mutadas, respectivamente. As desvantagens de quimeras periclinais são que não podem ser usadas em melhoramento por cruzamento, se mutação não ocorreu em camada L-2 responsável pela produção de gametas, e não se pode propagar o tipo verdadeiro por gemas adventícias. O termo quimerismo expressa toda combinação estável de dois ou mais tecidos somáticos geneticamente diferentes (Przybyla, 1994 e Donini \& Sonnino, 1998).

$\mathrm{Na}$ maioria das plantas propagadas vegetativamente, a micropropagação fornece material mais adequado para irradiação de culturas in vitro, sendo o processo, para a maioria dessas plantas, bem desenvolvido. É recomendado para a irradiação de micropropágulos, meio de cultura simples, como MS, preferencialmente sem 
reguladores de crescimento, para iniciar e estabelecer culturas. O subcultivo de explantes irradiados por duas a quatro vezes $\left(\mathrm{V}_{1}\right.$ até $\left.\mathrm{V}_{4}\right)$ poderá resultar na separação dos tecidos quiméricos, quer de origem por mutagênese quer por variação somaclonal. Em muitos casos, a propagação convencional a partir de estacas ou tubérculos é requerida, antes da seleção de variantes, para eliminar efeitos fisiológicos de cultura de tecidos que podem simular variação somaclonal (Ahloowalia, 1998).

O uso direto de mutações é um processo valioso, especialmente quando o melhoramento de uma ou duas características facilmente identificáveis é desejado numa variedade bem adaptada. A principal vantagem é que o genótipo básico da variedade é levemente alterado, oposto a procedimentos envolvendo hibridações de duas variedades distintas. $\mathrm{O}$ uso indireto de mutações pode envolver o cruzamento de mutantes diferentes a partir da mesma variedade parental; cruzamentos de diferentes mutantes de linhas parentais diferentes; e cruzamento de duas variedades carregando aparentemente a mesma mutação na mesma variedade parental (Donini \& Sonnino, 1998).

A seleção de variantes é um passo importante no melhoramento por mutação e é em grande parte mais difícil do que a indução por si só. Os procedimentos consideram mutações detectáveis, em plantas simples, por inspeção visual combinada com procedimentos apropriados de separação (infecção artificial, indução de acamamento, estresses de temperatura, etc.) e mutações detectáveis, sobre uma base de progênies de plantas, invisíveis a olhos nus (características quantitativas: produção, proteína de semente, etc.) que podem ser identificadas somente através de análises bioquímicas ou biométricas na população total (IAEA, 1977).

Os trabalhos de obtenção de mutantes para tolerância ou resistência a doenças não são numerosas na literatura quanto para outras características, devido ao fato de que resistência àdoença está muito mais sob controle de genes dominantes e que a taxa para ocorrência de mutações dominantes é relativamente baixa. Resistência monogênica é freqüentemente raça-específica e é facilmente quebrada pela evolução da população do patógeno, sendo aconselhável ter mais de um gene de resistência na mesma variedade. Resistências não-específicas são controladas pela interação de vários genes, cuja probabilidade de mutação é mais alta do que para genes maiores, mas o efeito fenotípico dos genes menores mutados não são facilmente perceptíveis, cuja seleção adequada é mais difícil (Donini \& Sonnino, 1998). 
Para detecção de resistência ou tolerância a doenças induzida em plantas de propagação sexuada, poderão ser testados tratamentos das plantas M2 com material infeccioso tais como fungo, esporos e filtrados de cultura. A eficiência da seleção in vitro reside na capacidade de selecionar células mais apropriadamente, que sejam capazes de regenerar plantas, do que selecionar ao nível de plantas completas. Porém, as seleções estão restritas ao tipo de mutações que podem ser detectadas ao nível celular, tais como tolerância à salinidade, estresses minerais, herbicidas, toxinas relacionadas a doenças, etc. (Tulmann Neto et al., 1998).

O melhoramento por mutação, combinada com materiais cultivados in vitro tais como ápices caulinares, segmentos nodais e brotos adventícios e, a micropropagação de gemas axilares, é considerado como um processo válido para o isolamento de mutações somáticas. Em contraste ao método in vivo, cultivo in vitro resulta numa dissolução rápida da quimera e na recuperação de mutantes estáveis geneticamente (Tulmann Neto et al., 1998)..

Os mutantes isolados nas gerações $V_{2}$ e/ou $V_{3}$ podem ser avaliados pela estabilidade e multiplicados para se testar sua performance agronômica. Meristemas tratados com mutagênicos e cultivados in vitro favorecem que variantes sejam separados diretamente in vitro para um número de atributos favoráveis, incluindo resistência a estresses bióticos e abióticos (Donini \& Sonnino, 1998).

O método de melhoramento de plantas por indução de mutação está bem estabelecido. Segundo Ahloowalia \& Maluszynski (2001), mais de 1.800 cultivares foram obtidas direto ou indiretamente através de mutantes induzidos em plantas propagadas por sementes, tais como trigo, arroz, cevada, trigo, amendoim e feijão. Em plantas propagadas vegetativamente, 465 mutantes foram liberados, sendo a maioria plantas ornamentais (crisântemo, rosa, begônia, azalea, dália, etc.) e pouco em plantas frutíferas (maçã, pêra japonesa, toranja, banana, abacaxi, tâmara).

Uma cultivar de crisântemo apresentando flores de coloração vinho denominada "Magali" foi obtida por Adames et al. (1999) a partir de mudas da cultivar "Ingrid" (de coloração rosa escuro) irradiadas com raios-gama (dosagem 20 Gy) e seleção em $V_{2}$.

Devido à ausência de fonte de variabilidade genética em gergelim para tolerância a Phytophthora nicotianae var. parasítica, Pathirana (1992) submeteu sementes a diferentes doses de radiação gama. A partir da geração $\mathrm{M}_{2}$, selecionou em 
área de reconhecida ocorrência da doença, conseguindo na geração $M_{5}, 21$ linhas que apresentaram sobrevivência média de $43,3 \%$ (25-66\%) e média de cápsulas por planta de 42,0 (17-68) enquanto a cultivar tradicionalmente usada $7,2 \%$ e 34,6 , respectivamente, sendo nas doses de 450 e 600 Gy a maior geração de linhas tolerantes.

Tulmann Neto et al. (1995), partindo da irradiação gama (350 Gy) em semente de trigo da cultivar IAC-17, após vários ciclos de seleção em campo a partir da $\mathrm{M}_{2}$, obtiveram um mutante com redução da altura, tendência a sofrer menos acamamento e maior resistência a oídio, além do que as outras características da cultivar permanecerem inalteradas.

Em trabalho relatado por Ando et al. (1997), através da irradiação gama de estacas de pimenta-do-reino, foi possível selecionar plantas que mostraram tolerância àfusariose que sobreviveram durante oito anos em área de ocorrência da doença.

Mutantes resistentes à pinta preta em pêra japonesa causada por Alternaria alternata foram induzidos por irradiação gama em cultivares susceptíveis, tanto usando irradiação crônica quanto aguda. Em todos os mutantes, foi confirmada a resistência intermediária com vários níveis de tolerância (Yoshioka et al., 1999).

\subsubsection{Indução de mutação associada às técnicas in vitro}

Apesar da maioria das mutações induzidas ser recessiva e deletéria, este método tem apresentado uma grande contribuição ao melhoramento de plantas cultivadas. Os melhoristas de plantas dispõem de várias técnicas in vitro que, em combinação com mutações induzidas, podem acelerar os programas de melhoramento, pois podem aumentar a eficiência na geração de variabilidade, seleção e multiplicação dos genótipos desejados (Maluszynski et al., 1995). Esta técnica combinada permite o tratamento mutagênico de grande número de explantes e multiplicação dos genótipos selecionados num pequeno espaço e curta duração, sob situações livres de doença, com um risco mínimo de perda de variantes através de acidentes durante a propagação (Ahloowalia, 1998).

As técnicas in vitro oferecem uma ampla escolha de material de planta para tratamento mutagênico, as quais são mais apropriadas quando comparadas com tratamento de gemas in vivo, pois as estruturas a partir das quais as plantas serão originadas são compostas de poucas ou uma célula. Este fato diminui o risco de 
obtenção de plantas quiméricas e aumenta a probabilidade de células mutadas expressarem a mutação no fenótipo, pois mutação é um evento de célula simples e os regenerantes podem se originar de um grupo de células (Predieri, 2001).

Entretanto, a aplicação de mutações no melhoramento de plantas será mais bem explorada a partir da disponibilidade de protocolos de cultura de tecidos para micropropagação de plantas e regeneração a partir de células e tecidos, e de tecnologias de marcadores moleculares, tanto para investigar variações dentro de populações quanto para identificar mutantes com características desejáveis (Predieri, 2001). Variações causadas por mutações induzidas não são essencialmente diferentes daquelas originadas por mutações espontâneas, e, esses mutantes são uma alternativa científica àengenharia genética de plantas (Predieri, 2001).

Os dois novos grupos de tecnologias, cultura in vitro e métodos moleculares, têm criado um novo paradigma no uso de mutações no melhoramento de plantas. As mutações induzidas têm então assumido uma nova dimensão, tanto no melhoramento de plantas quanto na exploração da biologia (Ahloowalia \& Maluszynski, 2001).

A irradiação de plantas cultivadas in vitro fornece uma forma de tratar grandes populações, através da irradiação de plantas micropropagadas, gemas axilares, adventícias, meristemas apicais, cultura de calos regenerativos, anteras e microsporos, e protoplastos e embriões somáticos, em placas de Petri ao invés de plantas em campo. No melhoramento convencional, as populações se originam a partir de variabilidade natural, recombinação e seleção, enquanto o melhoramento moderno envolve variabilidade induzida, seleção, avaliação e multiplicação de genótipos desejados, pois os melhoristas possuem a opção de uso de cultivo in vitro para multiplicação, métodos moleculares para selecionar genótipos específicos, indução de mutação para aumentar e gerar variabilidade, condições ambientais controladas para manipular crescimento e floração, informática para auxiliar o processamento de dados, e colaboração internacional para intercâmbio de germoplasma (Ahloowalia \& Maluszynski, 2001).

Gao et al. (1992), ao analisarem os efeitos da radiação gama no cultivo in vitro de híbrido de arroz do grupo indica, verificaram que explantes do tipo inflorescência jovem e embrião maduro foram mais satisfatórios tanto para produção de calos e regeneração de brotos in vitro quanto para mutagênese. A exposição de embriões imaturos à dose de 10 Gy e de calos derivados de sementes maduras æ̀s 
doses de 2,5 a 5 Gy levou a uma maior taxa de indução de calos e regeneração de plântulas, sendo que as doses de 5 a 10Gy em inflorescência jovem e 25 a 50 Gy em embriões maduros foram as mais efetivas para cultivo in vitro e na geração de variantes desejáveis quanto àmaturidade precoce, estatura baixa e alta capacidade de perfilhamento.

Latado et al. (1996) submeteram pedicelos de botões florais imaturos da cultivar Repin rosa de crisântemo àradiação gama na dose de 8Gy e os cultivaram in vitro. As plantas regeneradas por organogênese direta foram avaliadas em campo, sendo selecionados 46 mutantes para coloração da inflorescência e um mutante de folhas variegadas, sendo a inflorescência dos mutantes de uma única cor.

Predieri et al. (1997) associaram irradiação gama em gemas in vitro de pereira à redução do tamanho das árvores, principalmente levando em consideração que, para cada geração a partir de sementes, são necessários quatro anos. Utilizando uma dosagem de 3,5 Gy $\left(\mathrm{LD}_{50}\right)$ e após três ciclos de proliferação de brotos, os brotos enraizados foram aclimatados e as mudas transferidas para campo. Nas plantas selecionadas para hábito compacto (variação entre 0,5 a 2,8\% de plantas selecionadas por total de gemas irradiadas, entre as 4 cultivares) não se tem observado quimerismo nas plantas.

A variação somaclonal pode ser herdada geneticamente e é genótipo dependente. É uma técnica relativamente simples, usável onde outros métodos não são possíveis ou onde genes de resistência ou genes de interesse não estão disponíveis. Mehta \& Angra (2000), ao utilizarem sete cultivares de trigo com certo nível de tolerância à doenças, observaram que as plantas R2 (somaclones regenerados na segunda geração), regeneradas através da passagem por calos, apresentaram variação para resistência a Bipolaris sorokiniana e Magnaporthe grisea, mas não para Xanthomonas campestris pv. undulosa.

\subsubsection{Seleção in vitro}

A seleção de genótipos desejados é um passo crítico no melhoramento de plantas. A alta eficiência de sistemas de seleção in vitro ao nível celular reside no fato de que é possível crescer milhões de células numa placa de Petri ou frasco e atingir multiplicação rápida de populações de células em meios definidos. Após tratamentos mutagênicos, as plantas regeneradas a partir de células mutadas podem ser 
selecionadas in vitro por exposição das células regenerativas e tecidos a condições de estresses, e as plantas pré-selecionadas podem então ser testadas em campo. Alternativamente, as plantas regeneradas podem ser crescidas no campo e submetidas à seleção. $O$ termo variante é usado para definir um fenótipo novo. Somente evidência genética ou molecular pode estabelecer o "status" como um mutante. Em muitos casos, os variantes selecionados in vitro foram observados ser mutantes e apresentaram herança Mendeliana simples (Ahloowalia, 1998).

As características passíveis de seleção in vitro incluem tolerância a calor, frio e injúria ao congelamento; comprimento do dia; tolerância salina; resistência a fungo e bactéria (co-cultivo do hospedeiro com toxinas ou patógeno); tolerância à seca; resistência a herbicidas e antibióticos; tolerância à toxicidade de metais (alumínio, cobre, zinco, chumbo) e baixos níveis de NPK; resistência a nematóides de raiz (cocultivo de cistos com raízes de planta); e simbiose aperfeiçoada para fixação de nitrogênio (co-cultivo da bactéria ou micorriza com raízes ou planta completa). A aplicação de uma simples dose severa para seleção é preferível do que aumento gradativo, pois as culturas in vitro são reconhecidas em tolerar estresses, através da adaptação e habituação, antes do que resistência genética (Ahloowalia, 1998).

Contudo, o método de seleção in vitro mais efetivo para regeneração de plantas de calos embriogênicos de trigo para tolerância à salinidade, observada por Barakat \& Abdel-Latif (1996), foi através do aumento gradativo na concentração $\mathrm{NaCl}$ (5 a $9 \mathrm{~g} /$ ) quando comparado com outros métodos, os quais utilizaram concentração fixa de $\mathrm{NaCl}$ ou meios de cultura livres de $\mathrm{NaCl}$.

A mutagênese de gema, mesmo estando associada a quimerismo, através da irradiação de ápices, seguida por dissolução das quimeras, pode ser o mais eficiente uso no melhoramento por mutação in vitro, principalmente para culturas onde o caráter mutante desejado deva estar combinado com retenção de vigor e onde vigor esteja correlacionado com produção. Porque uma vez as quimeras tenham sido eliminadas por pelo menos três ciclos de subcultivo in vitro, os "homohistonts" podem ser submetidos à seleção in vitro. Seleção empírica contra metabólitos de fungo parecem resultar em variantes potencialmente proveitosos (Cassels, 1998).

A possibilidade de executar uma seleção in vitro depende, acima de tudo, da disponibilidade de um sistema eficiente de regeneração e propagação clonal (Predieri, 2001). Seleção com toxina específica do hospedeiro podem resultar em plantas 
resistentes a toxina, com completa resistência ao patógeno (resistência qualitativa), provavelmente resultante de um gene maior, enquanto que seleção para um nível aumentado de tolerância poderia selecionar indivíduos com resistência incompleta, possivelmente determinada por mutações em genes menores (resistência quantitativa). Ambas são úteis, mas desde que mutações nos patógenos ocorrem para quebrar a resistência das plantas, a resistência quantitativa ou resistência poligênica parece ser capaz de produzir resultados mais duráveis. Deste modo, um protocolo compreensivo de operação deveria vincular seleção in vitro, verificação in vivo (em casa de vegetação) das características modificadas, e avaliação acurada em campo da ocorrência sobre estabilidade e utilidade dos caracteres melhorados (Predieri, 2001).

Para a seleção de genótipos resistentes a doenças, além da geração de variabilidade genética, é necessário um método adequado e confiável para a identificação. Fungos do gênero Fusarium produzem uma variedade de metabólitos ativos biologicamente em filtrado de cultura. Hidalgo et al. (1998) comprovaram o efeito fitotóxico de filtrado do cultivo em "Czapek-Dox broth" do fungo Fusarium subglutinans, agente causal da doença fusariose em abacaxizeiro, em cultivares resistentes e susceptíveis de abacaxizeiro tanto em folhas (concentração do filtrado a $80 \% \mathrm{v} / \mathrm{v}$ ) quanto em calos cultivados in vitro (10 a $30 \% \mathrm{v} / \mathrm{v}$ ). Resultado semelhante foi observado por Borrás et al. (2001) ao testarem diferentes concentrações do filtrado, cujos efeitos em folhas (acima de $50 \% \mathrm{v} / \mathrm{v}$ ) possibilitaram a separação entre as cultivares susceptíveis dos resistentes. Hidalgo et al. (1999) também observaram que o filtrado de cultura de Fusarium subg/utinans (4 a $20 \%$ v/v) em meios de cultura reduziu a formação de brotos in vitro a partir de explantes de "plantlets" e a regeneração de plantas a partir de calos, derivados de cultivares susceptíveis, mas as cultivares resistentes apresentaram também resistência aos efeitos do filtrado. Esta metodologia se constitui numa alternativa viável em programas de melhoramento genético do abacaxizeiro para seleção de genótipos resistentes àdoença causada por esse fungo.

Matsumoto et al. (1999a), visando estabelecer uma estratégia de obtenção de plantas de bananeira resistentes àdoença causada por Fusarium, desenvolveram uma técnica de co-cultivo in vitro do fungo com grupo de múltiplas gemas proliferadas in vitro. Produziram o filtrado altamente tóxico com variedades susceptíveis (cv. Maçã) e o menos tóxico com variedade resistente (cv. Nanicão), tendo indicado como uma alternativa efetiva para seleção in vitro de mutantes. Tanto que, utilizando os 
mutagênicos químicos EMS (0,3\%) e DMSO (4\%) em grupos de gemas de bananeira (cv. Maçã) obtidas in vitro, e seleção in vitro com 10 e 15\% do filtrado a partir desta técnica de co-cultivo, selecionaram, após sucessivos ciclos de seleção in vitro e inoculação artificial em casa-de-vegetação, no primeiro experimento três clones e no segundo experimento nove clones, dos quais pelo menos um apresentou clara resistência em campo àdoença da murcha por Fusarium Matsumoto et al. (1999b).

As variações quanto à susceptibilidade e resistência in vitro às toxinas de Fusarium se devem principalmente à variedade ou genótipo, tanto quanto observado ao ataque do patógeno sob condições de campo. Essas variações refletem os mecanismos de resistência que operam a vários níveis, desde a prevenção contra a invasão e expansão do fungo à tolerância ou degradação à toxina (McLean, 1996). Vários metabólitos por Fusarium são produzidos, tais como micotoxinas, fitotoxinas, reguladores de crescimento de planta, enzimas extracelulares, antibióticos e pigmentos, cujos efeitos in vitro nem sempre refletem a situação in vivo. Então, ao usar a seleção in vitro, é recomendável que mais de um metabólito seja adicionado ao meio seletivo, pois é altamente provável que mais de um esteja envolvido na patogênese.

A presença e a concentração desses metabólitos produzidos pelos patógenos dependem principalmente da condição de cultivo e da patogenicidade dos isolados usados (Remotti et al., 1997). Jin et al. (1996) observaram que isolados de Fusarium solani de outros hospedeiros, diferentes da soja, não causaram nesta, os mesmos sintomas da síndrome de morte súbita e, os filtrados de cultura do fungo tiveram significativamente menor efeito fitotóxico a calos, em soja, do que tiveram filtrados a partir de isolados do fungo da própria soja que causavam a doença. O filtrado de cultura de Fusarium solani, isolado de soja com síndrome da morte súbita, causou tanto redução do crescimento quanto escurecimento dos calos e esses efeitos apresentaram correlação positiva com as taxas de sintomas de severidade observadas quando inoculados em cultivar em condições de campo.

O ácido fusárico foi o primeiro produto de fungo produzido em cultura, uma toxina com atividade biológica que foi purificada e identificada, e que tem sido isolado de várias plantas infectadas com Fusarium (banana, algodão, melão, caupi) mas não de outras. Portanto, isto evidencia que ácido fusárico é produzido em vários hospedeiros infectados com Fusarium (Beckman, 1987). 
Matsumoto et al. (1995) observaram que a concentração de 0,1 mM de ácido fusárico inibiu totalmente o crescimento tanto de plantas de bananeiras tolerantes (cv. Nanicão) quanto de susceptíveis (cv. Maçã), como agente seletivo contra a murcha de fusarium da raça I do Fusarium oxysporum f.sp. cubense. Esta estratégia permitiu a seleção de variantes tolerantes após tratamento de múltiplas gemas com mutagênicos químicos (EMS e DMSO), cujos resultados foram confirmados em testes de casa-devegetação. Em contraste, sem uso de mutagênico, linhas de células de gladíolo susceptível ao fungo $F$. oxysporum f. sp. gladioli foram selecionadas após cultivo sob pressão de ácido fusárico (acima de 0,5 mM) de células em suspensão, cujas plantas regeneradas dos calos, dessas linhas de células insensíveis a ácido fusárico, expressaram tolerância a essa toxina quando cultivadas in vitro na presença deste agente seletivo (Remotti, et al., 1997).

Entretanto, em bananeira, o uso de filtrado da cultura do fungo Fusarium oxysporum f. sp. cubense raças 1 e 4 e ácido fusárico, em meio de cultivo in vitro de ápices caulinares, não discriminou cultivares resistentes de susceptíveis, pois em ambos meios de seleção os explantes das cultivares foram susceptíveis. Além disso e como as respostas in vivo não tiveram ligação com as in vitro, Morpurgo et al. (1994), sugeriram que esta metodologia in vitro, tanto com filtrado quanto com toxina hospedeiro não-específica, não seja aplicável em bananeira para seleção de genótipos resistentes ao fungo.

Em cultivares de batata com resistência e com resistência intermediária, o efeito do filtrado de cultura de Alternaria solani foi favorável àregeneração de brotos, pois em todas as concentrações testadas houve um aumento no número de brotos induzidos quando comparado ao meio de cultura sem filtrado. Segundo Lynch et al. (1991), esta resposta deve estar associada à mudança no balanço endógeno de fitohormônios nos explantes cultivados ou a possível mudança na sensibilidade das células competentes a substâncias exógenas de crescimento.

O desenvolvimento de sistemas de seleção para resistência à doença em cultura tem sido usar toxinas do patógeno como agente seletivo. Na maioria dos casos, nesse sistema, a resistência a toxinas expressada pelas plantas regeneradas correlacionou com aumento significativo nos níveis de resistência à doença nas plantas, cujas alterações genéticas foram transmitidas às progênies das plantas selecionadas, em todos os casos estudados. Entretanto, os problemas do uso de 
toxinas de patógeno como agente seletivo se limitam a três grandes áreas: a) a falta de toxinas suficientemente caracterizadas que têm um papel em doenças importantes; $b$ ) expressão diferencial em nível de célula simples e em nível de planta completa; e c) a possibilidade que os níveis de resistência desejados não podem ser obtidos devido ao modo de ação da toxina envolvido. Por isso, para Daub (1986), os filtrados de cultura não são os melhores agentes para seleção para resistência, mas se outros métodos não estiverem disponíveis, estes podem ser usados, desde que algumas precauções sejam guardadas contra seleção para resistência a substâncias não específicas encontradas nos filtrados.

\subsubsection{Seleção através da obtenção de plantas transgênicas}

Para a obtenção de plantas transgênicas, os sistemas de transferência de DNA que rotineiramente têm sido usados para introduzir genes em plantas cultivadas são Agrobacterium tumefaciens, eletroporação e bombardeamento de partículas. No desenvolvimento de programas de melhoramento de plantas, permite-se a introdução de genes de espécies não relacionadas e igualmente de outros reinos (bactéria, fungo, animais). Todos esses sistemas requerem a aplicação das técnicas de cultura de tecidos para a regeneração de plantas e diferem entre si, principalmente na maneira pela qual o DNA é transferido para dentro da célula da planta (De Block, 1993).

Plantas transgênicas de amendoeira com genes gus ( $\beta$-glucuronidase) e nptll ("neomycin phosphotransferase II") foram obtidas via transformação por Agrobacterium a partir de 1419 folhas e um protocolo eficiente de regeneração de plantas via organogênese foi estabelecido. Quatro brotos selecionados com kanamicina apresentaram amplificação de fragmentos do DNA, mas após micropropagação apenas "plantlets" clonados de um deles apresentaram consistente resultado positivo de detecção histoquímica de GUS e amplificação em PCR, cuja hibridização em Southern blot confirmou integração estável dos transgenes no genoma da planta (Miguel \& Oliveira, 1999).

Através do bombardeamento de brotos meristemáticos, de plântulas in vitro, com partículas de ouro, Zhang et al. (1999) obtiveram sucesso na transformação de uma cultivar de aveia e outro de cevada com genes uidA e bar, cujo protocolo desenvolvido produziu plantas transgênicas em todas as linhas, confirmadas por 
análises de hibridização do DNA e de expressão e transmissão dos transgenes nas progênies.

Kondo et al. (2000), utilizando um protocolo eficiente de regeneração in vitro, produziram plantas transgênicas de alho com o gene uid A. Calos foram imersos em solução de Agrobacterium tumefaciens e co-cultivados no escuro por três dias e, em seguida, em meio de propagação de calos com agente seletivo (higromicina) por dois meses e transferidos para meio de indução de brotos. Após 4 a 5 meses, emergiram brotos e regeneraram 15 plantlets transgênicos. Expressão transiente GUS foi detectada e, das folhas das plantas transgênicas, crescidas em casa de vegetação após aclimatação, DNA genômico foi extraído cujas análises em Southern blot evidenciaram a integração do gene no DNA genômico da planta.

Resultados positivos foram obtidos por Zhang et al. (2000) em mandioca, utilizando o sistema de regeneração de plantas via organogênese e o método de bombardeamento de partículas revestidas com genes semelhantes. Bombardearam-se cotilédones de embriões somáticos e plantas transformadas foram regeneradas, comprovando-se pelo teste histoquímico de GUS e pelas análises de Southern e Northern blots de hibridizações de DNA e RNA, respectivamente.

Plantas de bananeira da cultivar Rasthali (AAB) também foram transformadas quando Ganapathi et al. (2001) utilizaram o sistema mediado por Agrobacterium e um protocolo eficiente de regeneração de plantas a partir de células embriogênicas em suspensão. Nessas células cultivadas com Agrobacterium foram integrados ao genoma os genes gus A (repórter) e als (gene de seleção para resistência ao herbicida sulfonylurea), em cujas plantas transformadas regeneradas por embriogênese somática foi confirmada a integração do DNA por análises de Southern blot e teste histológico de GUS, sendo observado nos frutos das plantas transgênicas expressão positiva de GUS.

O método de transformação genética mediada por Agrobacterium tumefaciens é muito eficiente em muitas plantas, principalmente nas dicotiledôneas, mas algumas plantas dicotiledôneas e a maioria das monocotiledôneas são recalcitrantes à infecção por Agrobacterium tumefaciens. Ke et al. (2001) desenvolveram um método eficiente de transferência de gene para plantas de arroz e soja, plantas recalcitrantes, através da utilização de linhagens de Agrobacterium tumefaciens modificadas com o gene mutante constitutivo virGN54D, cuja 
superexpressão aumenta o nível de expressão dos genes vir muito importantes na virulência da bactéria. Utilizando este método, brotos de plântulas, após co-cultivo com Agrobacterium tumefaciens, foram cultivados em meios de cultura com agente seletivo e de regeneração de plantas, onde foram regenerados transformantes. Testes de GUS confirmaram a transformação, porém os resultados indicaram que, durante o processo, quantidades diferentes de DNA foram transferidas para cada espécie. 


\section{MATERIAL E MÉTODOS}

O presente trabalho foi desenvolvido através do estabelecimento de estratégias apropriadas para mutagênese, com mutagênico físico do tipo radiação gama, associada às técnicas in vitro e métodos adequados de seleção visando a obtenção de material resistente e/ou tolerante àdoença fusariose em pimenta-do-reino. Além disso, testou-se várias alternativas para indução de calos visando regeneração de plantas e realizou-se avaliação agronômica de plantas originadas de estacas de pimenta-do-reino da cultivar Cingapura, que sofreram seleções artificial e natural contra o fungo.

\subsection{Aplicação das técnicas in vitro}

Para a aplicação da mutagênese associada às técnicas in vitro, o trabalho foi desenvolvido através da definição do processo de micropropagação, estratégias de mutagênese a partir da determinação da radiosensitividade de gemas à irradiação gama, determinação de condições in vitro para seleção de variantes tolerantes ao filtrado da cultura do fungo Fusarium solani $f$. sp. piperis, e condições para seleção in vivo com suspensão de esporos do fungo, além de atividades de indução de calos para regeneração de plantas (Figura 2). 


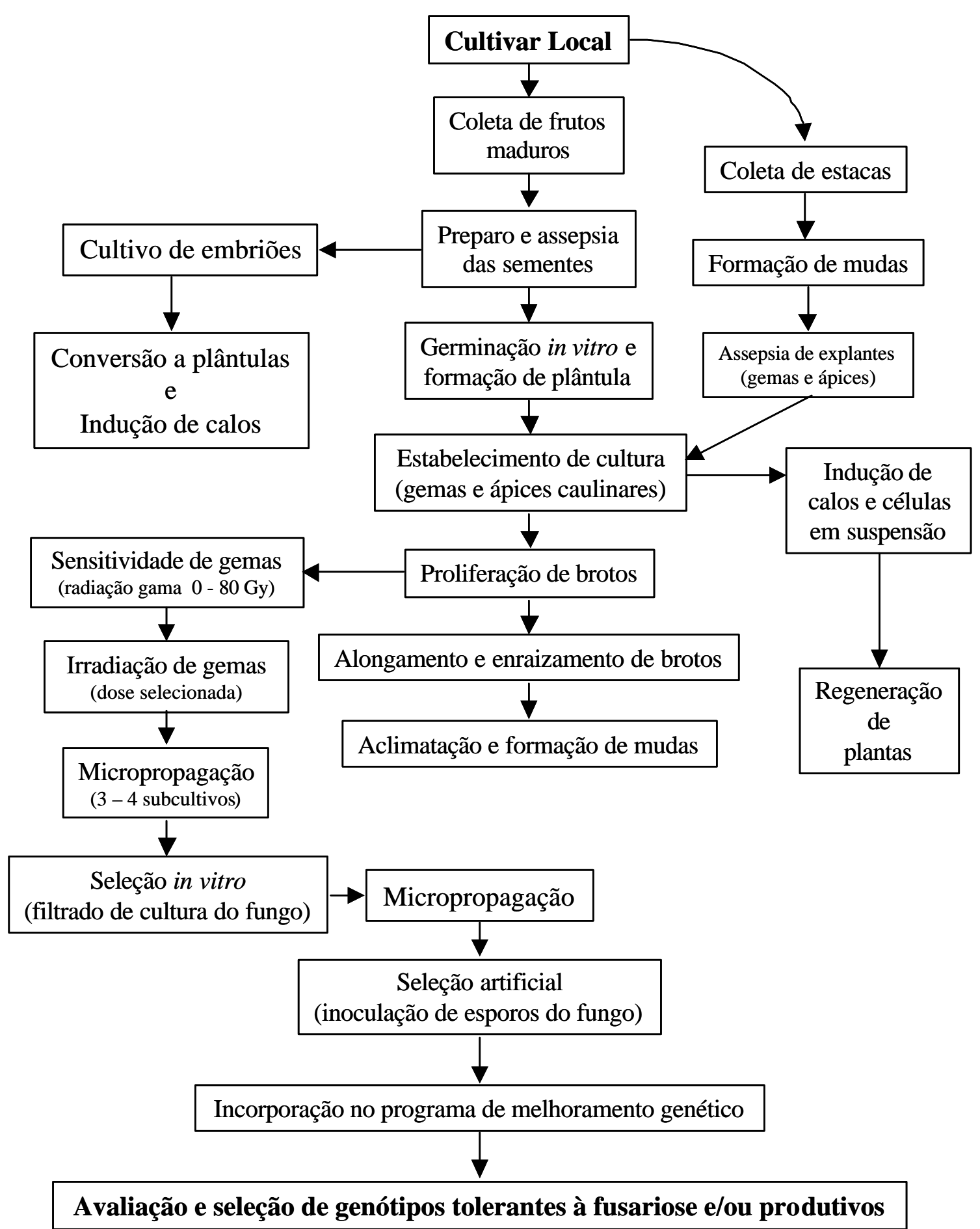

Figura 2 - Metodologia para desenvolvimento das técnicas in vitro visando mutagênese e seleção de variantes tolerantes àdoença fusariose em pimenta-do-reino. 


\subsubsection{Produção de plantas doadoras de explantes}

Um fator limitante no estabelecimento do processo de micropropagação é a obtenção de explantes livres de contaminantes. Aspecto apresentado pelas plantas de pimenta-do-reino que apresentam fungos e bactérias endógenas. Para tornar viável o processo, várias estratégias de produção de plantas doadoras de explantes foram adotadas, quais sejam: a partir de estacas para formação de mudas em casa-devegetação; a partir de sementes sob cultivo in vitro; e a partir de embriões zigóticos.

\subsubsection{A partir de estacas}

Estacas de ramos ortotrópicos com dois a três nós foram podadas de plantas adultas, crescidas em área de produção de pimenta-do-reino no município de ToméAçu, Estado do Pará, que em Piracicaba, São Paulo, foram transferidas para bandejas plásticas com vermiculita sob condições de alta umidade relativa do ar para enraizamento (Figura 3a). As estacas enraizadas foram repicadas para sacos plásticos de polietileno $18 \times 12 \mathrm{~cm}$ com substrato comercial (Plantmax) para desenvolvimento de brotações. As estacas com brotações foram transferidas para vaso de barro $22 \times 20 \mathrm{~cm}$ contendo substrato do tipo solo para formação de mudas. Durante a formação das mudas, solução com metade da concentração de sais do meio básico de cultura de MS (Murashige \& Skoog, 1962) foram adicionadas ao solo mensalmente.

Também, cerca de 20 estacas de plantas $V_{5}$ foram obtidas, com oito anos de cultivo de cada uma de seis linhagens selecionadas contra a doença fusariose (C25, $\mathrm{C} 45, \mathrm{C} 70, \mathrm{C} 123, \mathrm{C} 132$ e C170), e submetidas àformação de mudas. Essas plantas $\mathrm{V}_{5}$ tiveram origem a partir de estacas que foram submetidas à irradiação gama, e as estacas foram tratadas por imersão em solução de NAA (0, 10, 50 e 100 mg.L-1 $)$ por 12 horas e transferidas para bandejas com substrato de vermiculita sob condições de câmara úmida. Após 4 a 6 semanas, as estacas enraizadas foram transferidas para vasos de cerâmica $(22 \times 20 \mathrm{~cm})$ contendo substrato composto de Plantmax e vermiculita na proporção (2:1 v/v) para desenvolvimento das brotações e formação de mudas. 


\subsubsection{A partir de sementes de cultivar tradicional}

Para a produção de plântulas in vitro, inicialmente frutos no estádio maduro de coloração amarelo a vermelho (Figura $\mathbf{3}$ ), a partir de plantas tradicionalmente cultivadas pelos produtores, foram coletados e submetidos à assepsia, conforme Lemos et al. (1997) para obtenção de sementes assépticas e germinação in vitro. Os frutos foram lavados em água corrente e detergente neutro, imersos em solução de hipoclorito de sódio a 0,5\% ( $\mathrm{NaClO} v / \mathrm{v})$ durante a noite, e posteriormente despolpados. As sementes obtidas foram lavadas em água corrente e, sob câmara de fluxo laminar asséptica, submetidas ao processo de desinfestação por imersão em álcool $70 \%$ (v/v) por um minuto e em solução de hipoclorito de sódio $1 \%$ (v/v) por 15 minutos, e lavagens por cinco vezes em água destilada autoclavada. As sementes foram transferidas para filtros de papel esterilizados para retirar o excesso de água e inoculadas em tubos de ensaio $(25 \times 170 \mathrm{~mm})$ com meio de cultura básico MS com completa (MS) ou com metade dos sais ( $1 / 2 \mathrm{MS}$ ), acrescido com diferentes suplementos, num total de oito tratamentos, quais sejam:

1 - MS + carvão ativado $0,2 \%+\mathrm{NaH}_{2} \mathrm{PO}_{4} 0,17 \mathrm{~g} \cdot \mathrm{L}^{-1}$;

$2-\mathrm{MS}+\mathrm{NaH}_{2} \mathrm{PO}_{4} 0,17$ g. $\mathrm{L}^{-1}$

3 - MS + carvão ativado $0,2 \%+\mathrm{NaH}_{2} \mathrm{PO}_{4} 0,17 \mathrm{~g} \cdot \mathrm{L}^{-1}+\mathrm{NAA}$ e BAP $\left(0,5 \mathrm{mg} \cdot \mathrm{L}^{-1}\right.$ de cada);

$4-\mathrm{MS}+\mathrm{NaH}_{2} \mathrm{PO}_{4} 0,17 \mathrm{~g} \cdot \mathrm{L}^{-1}+\mathrm{NAA}$ e BAP $\left(0,5 \mathrm{mg} \cdot \mathrm{L}^{-1}\right.$ de cada);

$5-1 / 2 \mathrm{MS}+$ carvão ativado $0,2 \%+\mathrm{NaH}_{2} \mathrm{PO}_{4} 0,17 \mathrm{~g} \cdot \mathrm{L}^{-1}+\mathrm{NAA}$ e BAP $\left(0,5 \mathrm{mg} \cdot \mathrm{L}^{-1} \mathrm{de}\right.$ cada);

$6-1 / \mathrm{MS}+\mathrm{NaH}_{2} \mathrm{PO}_{4} 0,17 \mathrm{~g} \cdot \mathrm{L}^{-1}+\mathrm{NAA}$ e BAP $\left(0,5 \mathrm{mg} \cdot \mathrm{L}^{-1}\right.$ de cada $)$;

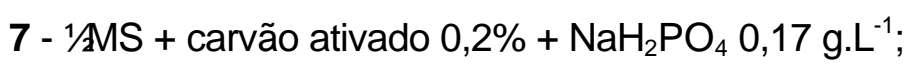

$8-1 / \mathrm{AMS}+\mathrm{NaH}_{2} \mathrm{PO}_{4} 0,17 \mathrm{~g} \cdot \mathrm{L}^{-1}$.

Cada tratamento foi constituído de 35 tubos de ensaio com uma semente por tubo e cultivado sob fotoperíodo de 16 h.luz.dia ${ }^{-1}$, com intensidade de luz de cerca de 3.000 lux proporcionada por três lâmpadas fluorescentes brancas de $20 \mathrm{w}$ e temperatura de $25 \pm 3^{\circ} \mathrm{C}$. Os dados tomados após 69 dias de cultivo foram quanto ao número de sementes que apresentaram respostas e quanto ao desenvolvimento de plântula normal (PN), plântula anormal (PA) e formação de calos. Os dados foram analisados quanto à percentagem de respostas das sementes aos diferentes tratamentos. 


\subsubsection{A partir de sementes de plantas $\mathrm{V}_{5}$}

Baseado no experimento anterior, para produção de plântulas a partir de sementes das plantas $V_{5}$ originadas de estacas irradiadas com raios-gama, outro experimento foi instalado, em que sementes foram submetidas ao tratamento de assepsia, conforme citado anteriormente, e semeadas in vitro em meio básico de cultura MS, com adição ou não de carvão ativado $(0,2 \%)$, combinado ou não com $\mathrm{NaH}_{2} \mathrm{PO}_{4} \quad\left(0,17\right.$ g. $\left.\mathrm{L}^{-1}\right)$. Esse experimento foi instalado num fatorial $2 \times 2$, em delineamento inteiramente casualizado, com quatro tratamentos e nove repetições. Cada linhagem $V_{5}$ representou uma repetição (linhagens C137; C166; C132; N27; N121; C70; C45; N135; e CING.) em cada tratamento. Os dados tomados foram quanto æ̀s percentagens de plântulas formadas em cada tratamento, considerando o número total de plântulas obtido em cada linhagem em todos os tratamentos igual a 100\%. Cada linhagem foi constituída por 36 tubos de ensaios, sendo 9 tubos de cada tratamento e uma semente por tubo. Os dados foram submetidos à análise de variância e testes de comparação de média de Tukey ao nível de $5 \%$ de probabilidade,

utilizando a transformação de $\sqrt{x+0,5}$. Empregou-se o teste de qui-quadrado para comparar os efeitos de $\mathrm{NaH}_{2} \mathrm{PO}_{4}$ e carvão ativado e a performance das linhagens quanto àgerminação e desenvolvimento de plântula.

\subsubsection{A partir de embriões zigóticos}

Frutos foram coletados de plantas em casa-de-vegetação, despolpados e as sementes esterilizadas. Sob condições assépticas e com auxílio de lupa binocular, embriões zigóticos foram isolados das sementes e inoculados em 20 tubos de ensaio de cada tratamento, de 8 tratamentos descritos abaixo, num total de 160 tubos de ensaios.

1. 1 MS;

2. ${ }^{1} / \mathrm{MS}+0,17 \mathrm{~g} \cdot \mathrm{L}^{-1} \mathrm{NaH}_{2} \mathrm{PO}_{4}$

3. ${ }^{1} / \mathrm{MS}+0,17 \mathrm{~g} \cdot \mathrm{L}^{-1} \mathrm{NaH}_{2} \mathrm{PO}_{4}+0,2 \%$ de carvão ativado

4. ${ }^{1} / \mathrm{MS}+0,17 \mathrm{~g} \cdot \mathrm{L}^{-1} \mathrm{NaH}_{2} \mathrm{PO}_{4}+0,2 \%$ de carvão ativado + BAP e NAA $\left(0,5 \mathrm{mg} \cdot \mathrm{L}^{-1}\right)$

5. MS

6. $\mathrm{MS}+0,17 \mathrm{~g} \cdot \mathrm{L}^{-1} \mathrm{NaH}_{2} \mathrm{PO}_{4}$

7. $\mathrm{MS}+0,17 \mathrm{~g} \cdot \mathrm{L}^{-1} \mathrm{NaH}_{2} \mathrm{PO}_{4}+0,2 \%$ de carvão ativado 
8. $\mathrm{MS}+0,17 \mathrm{~g} \cdot \mathrm{L}^{-1} \mathrm{NaH}_{2} \mathrm{PO}_{4}+0,2 \%$ de carvão ativado + BAP e NAA $\left(0,5 \mathrm{mg} \cdot \mathrm{L}^{-1}\right)$. Sacarose $30 \mathrm{~g} \cdot \mathrm{L}^{-1}$, phytagel $0,2 \%$ e pH 5,8 antes da autoclavagem a $121^{\circ} \mathrm{C}$ por 20 minutos.

Os embriões (Figuras $3 \mathbf{c}$ e $3 \mathbf{d}$ ) foram cultivados nas mesmas condições das sementes, em delineamento inteiramente casualizado com 20 repetições por tratamento, sendo um embrião por parcela. As respostas observadas foram quanto ao desenvolvimento de plântulas normais, anormais e embriões sem resposta, aos 30 dias de cultura. Os dados foram submetidos a teste de qui-quadrado e convertidos em percentagem.

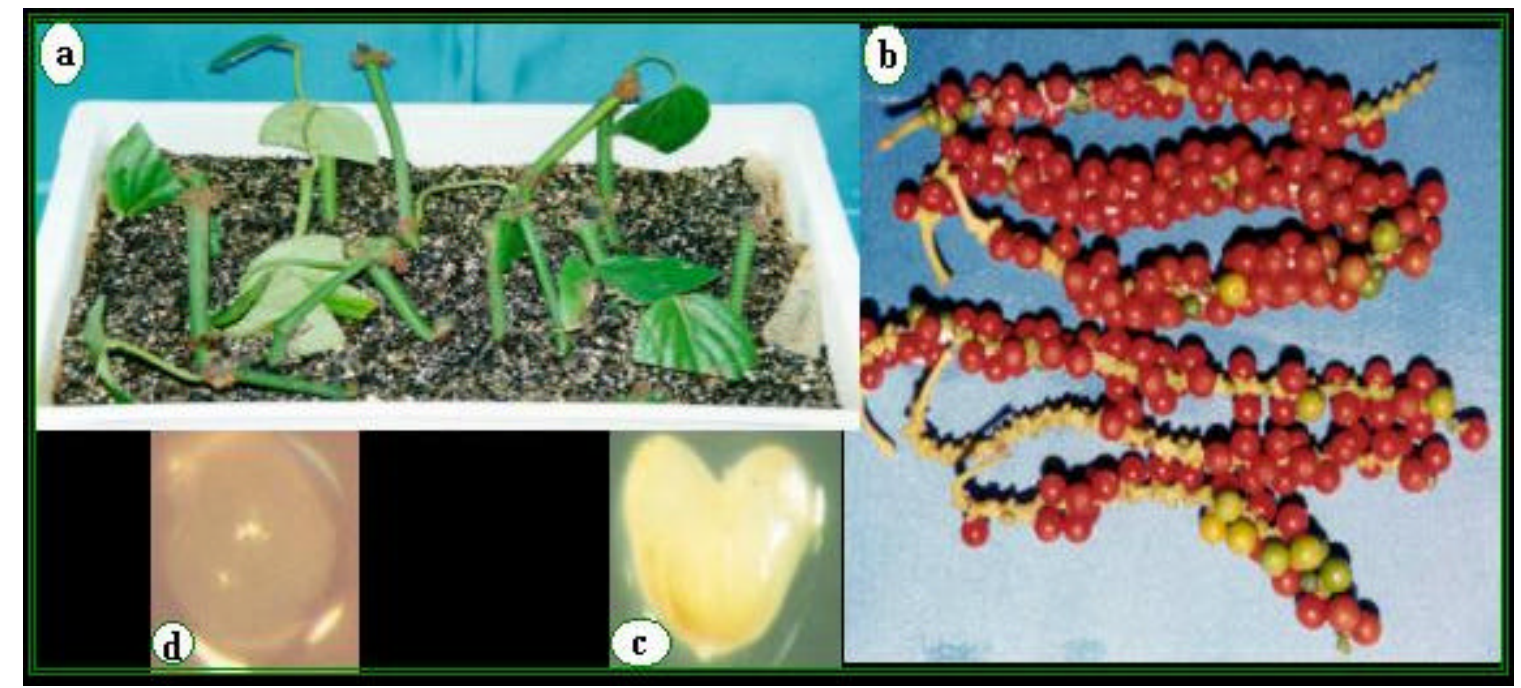

Figura 3 - Fontes doadoras de explantes.

a) estacas na fase de enraizamento

b) frutos no estádio maduro para obtenção de sementes

c, d) embriões zigóticos 


\subsubsection{Micropropagação}

Para o desenvolvimento do processo de micropropagação, inicialmente ápices caulinares e gemas axilares assépticas provenientes das plântulas produzidas in vitro foram utilizados. As etapas de estabelecimento de cultura e multiplicação de brotos, alongamento e enraizamento dos brotos produzidos, diferenciação de "plantlets" a partir de gemas, aclimatação e formação de mudas, e assepsia de explantes a partir de plantas propagadas via estacas foram realizadas.

\subsubsection{Estabelecimento e multiplicação de gemas}

Explantes como ápices caulinares e gemas axilares foram introduzidos em meio básico de cultura de Murashige \& Skoog (MS) suplementado com 0,2 mg. $\mathrm{L}^{-1}$ de ácido indolacético (IAA) e $0,5 \mathrm{mg} \cdot \mathrm{L}^{-1}$ de 6 -benzilaminopurina (BAP) em frasco cilíndrico de $300 \mathrm{ml}$ contendo $50 \mathrm{ml}$ do meio de cultura, e cultivados, por cerca de duas semanas, sob condições de fotoperíodo de 16 h.luz.dia ${ }^{-1}$, com intensidade luminosa de 3.000 lux proporcionada por três lâmpadas fluorescentes brancas por prateleira e temperatura de $25 \pm 3^{\circ} \mathrm{C}$.

Os explantes estabelecidos foram transferidos para mesmo meio básico de cultura MS com diferentes combinações de reguladores de crescimento (BAPxIAA) visando a proliferação de brotos. O delineamento experimental utilizado foi inteiramente casualizado num fatorial de $2 \times 4$, com duas concentrações de IAA $(0,0$ e $\left.0,2 \mathrm{mg} \cdot \mathrm{L}^{-1}\right)$ e quatro concentrações de $\operatorname{BAP}\left(0,1 ; 0,5 ; 1,0\right.$; e $\left.2,0 \mathrm{mg} \cdot \mathrm{L}^{-1}\right)$, num total de 8 tratamentos, com 3 a 10 repetições por tratamento, sendo cada repetição constituída de um frasco com 3 a 5 explante por frasco, durante dois subcultivos seguidos, realizados a cada 8 semanas. A avaliação foi quanto ao número de novas gemas diferenciadas por explante (gemas axilares e apicais) e os dados foram submetidos às análises estatísticas de variância e teste de comparação de média (teste Tukey), considerando a média por frasco em cada tratamento .

Testaram-se as concentrações de 1,5 e 3,0 mg.L ${ }^{-1}$ de BAP. Neste caso, o experimento foi instalado sob as mesmas condições de cultivo supracitadas, em delineamento inteiramente casualizado, constituído dos dois tratamentos (BAP a 1,5 e $\left.3,0 \mathrm{mg} \cdot \mathrm{L}^{-1}\right)$, com 9 repetições e cada repetição representada por um frasco com 3 a 5 explantes. Foram realizados dois subcultivos ( 8 e 4 semanas, respectivamente), cujos dados de média de número de novas gemas diferenciadas por explante foram 
analisados estatisticamente quanto a variância e teste Tukey para comparação de médias.

Um terceiro experimento foi instalado em delineamento inteiramente casualizado através de três subcultivos consecutivos, constituído de diferentes combinações de BAPxIAA, com pelo menos 6 repetições por tratamento. Cada repetição foi constituída de um explante por tubo de ensaio em três subcultivos consecutivos às 8,6 e 6 semanas, respectivamente. Os tratamentos estão representados na Tabela 1, cujo efeito foi medido através da avaliação quanto a diferenciação de novas gemas por explante. Os dados foram submetidos às análises de variância e testes de comparação de médias (Tukey e Duncan). Realizou-se análise conjunta dos três subcultivos em delineamento inteiramente casualizado, considerando cada subcultivo uma repetição, ou seja, três repetições por tratamento (BAPxIAA), num total de 13 tratamentos.

Tabela 1. Tratamentos correspondentes ao balanço exógeno entre BAP e IAA para diferenciação de novas gemas em explantes visando à proliferação de brotos no processo de micropropagação de pimenta-do-reino.

\begin{tabular}{cccccccc}
\hline BAP & \multicolumn{7}{c}{ IAA (mg. - $\left.^{-1}\right)$} \\
\cline { 2 - 8 }$\left(\mathrm{mg} \cdot \mathrm{L}^{-1}\right)$ & 0,0 & 0,1 & 0,2 & 0,3 & 0,5 & 1,0 & 2,0 \\
\hline 05 & $\mathrm{X}$ & $\mathrm{X}$ & $\mathrm{X}$ & $\mathrm{X}$ & $\mathrm{X}$ & & \\
1,0 & $\mathrm{X}$ & & $\mathrm{X}$ & & & $\mathrm{X}$ & $\mathrm{X}$ \\
2,0 & $\mathrm{X}$ & & $\mathrm{X}$ & & & & \\
4,0 & $\mathrm{X}$ & & $\mathrm{X}$ & & & \\
\hline
\end{tabular}

Ademais, um quarto experimento foi instalado em delineamento inteiramente casualizado, admitindo doze tratamentos (Tabela 2), a partir do meio básico de cultura MS com diferentes combinações de BAPXIAA e adição ou não de carvão ativado a $0,2 \%$, através de dois subcultivos e pelo menos quatro repetições por tratamento, representada a parcela por um frasco com cinco explantes por frasco. A avaliação foi quanto ao número de novas gemas por explantes e observações quanto a formação de raízes e calos na base dos explantes, a cada 6 semanas. Os dados foram submetidos à análise de variância num fatorial $2 \times 2 \times 6$ (dois subcultivos, adição ou não de carvão a $0,2 \%$ e seis combinações de IAAxBAP) e teste Tukey de comparação de média. 
Ressalte-se que no segundo subcultivo, o cultivo foi avaliado após 10 semanas quanto ao enraizamento dos explantes, comprimento das raízes e crescimento da parte caulinar, visando a aplicação dessas condições na diferenciação de "plantlets" a partir de gemas.

Tabela 2. Tratamentos correspondentes ao balanço exógeno entre BAP e IAA e carvão ativado em meio básico de cultura MS para diferenciação de novas gemas em explantes visando à proliferação de brotos no processo de micropropagação de pimenta-do-reino, em cada subcultivo.

\begin{tabular}{cccccc}
\hline \multirow{2}{*}{$\begin{array}{c}\text { BAP } \\
\left(\mathrm{mg} \cdot \mathrm{L}^{-1}\right)\end{array}$} & \multicolumn{4}{c}{ IAA $\left(\mathrm{mg} \cdot \mathrm{L}^{-1}\right)$} & $\begin{array}{c}\text { Carvão ativado } \\
(\%)\end{array}$ \\
\cline { 2 - 5 } & 0,0 & 0,1 & 0,2 & 0,5 & 0,2 \\
0,1 & $\mathrm{x}$ & $\mathrm{x}$ & $\mathrm{x}$ & $\mathrm{x}$ & 0,2 \\
0,5 & $\mathrm{x}$ & $\mathrm{x}$ & $\mathrm{x}$ & & 0 \\
0,5 & $\mathrm{x}$ & $\mathrm{X}$ & $\mathrm{x}$ & $\mathrm{x}$ & 0 \\
\hline
\end{tabular}

\subsubsection{Alongamento e enraizamento de brotos}

Os brotos obtidos nos primeiros experimentos na fase de proliferação de brotos foram transferidos para meios de cultura para alongamento e enraizamento. Para brotos menores que 2,0 cm, um experimento foi conduzido em delineamento inteiramente causalizado constituído de três tratamentos [NAA 0,5 mg.L ${ }^{-1} \mathrm{XGA}_{3}(0,0 ; 0,5$ e $\left.1,0 \mathrm{mg} \cdot \mathrm{L}^{-1}\right)$ ], 7 a 14 repetições por tratamento, cada parcela representada por um frasco, 5 a 10 brotos por frasco, cultivados durante quatro semanas, nas mesmas condições de cultivo adotadas na fase de proliferação de brotos. A avaliação foi realizada quanto a percentagem de brotos enraizados e número de raízes por broto. Os dados foram submetidos à análise de variância e teste Duncan para comparação de médias.

Para o enraizamento de brotos maiores que $2,0 \mathrm{~cm}$, estes foram cultivados em meio básico de cultura MS com diferentes concentrações de NAA $(0,0 ; 0,1 ; 0,5$ e $1,0 \mathrm{mg} \cdot \mathrm{L}^{-1}$ ) durante 4 semanas. As avaliações foram quanto ao número de raízes por broto e percentagem de brotos enraizados. Realizou-se análise de variância dos dados e o teste Duncan foi empregado para comparação de médias entre os tratamentos. 
A etapa de enraizamento, até então, era induzida a partir de brotos, mas observou-se que gemas cultivadas em meio básico de cultura MS na presença ou ausência de carvão ativado $(0,2 \%)$, por ocasião de experimento para multiplicação de gemas, diferenciaram brotos enraizados ("plantlets").

Gemas individuais, tanto apicais como axilares, no experimento de multiplicação de novas gemas, foi conduzido em meio básico de cultura MS, suplementado com seis combinações de BAPxIAA, com e sem adição de carvão ativado a $0,2 \%$ (Tabela 3), foi estendido até aos 60 dias de cultivo e avaliado quanto a indução de raízes através da percentagem de gemas que diferenciaram raízes, número e comprimento de raízes, e comprimento do sistema radicular. Os dados foram analisados num fatorial de $2 \times 6$, com ou sem carvão ativado e seis combinações de BAPxIAA, através da análise da variância e teste Tukey para comparação de médias. Os dados sobre a percentagem de gemas com diferenciação de raízes foram transformados por $\sqrt{x+0,5}$ para análise da variância e teste de comparação de média.

Visando padronizar a fase de enraizamento, sem passagem pela fase de alongamento, gemas axilares e apicais foram cultivadas em meio básico de cultura MS com completa ou metade da concentração dos sais, suplementado com diferentes auxinas exógenas para enraizamento (NAA ou IBA) nas concentrações de $0 ; 0,1 ; 0,5$; 1,0; 2,5; e 5,0 $\mu \mathrm{M}$ (Tabela 3). Neste caso, o delineamento inteiramente casualizado foi empregado, num total de 12 tratamentos, com 10 repetições por tratamento, sendo cada parcela representada por um frasco com cinco gemas. Os dados obtidos foram quanto a percentagem de explantes com diferenciação de raízes, número e comprimento das raízes por explante, e comprimento do sistema caulinar, além de observações quanto a espessura das raízes. Análises de variância e testes de comparação de médias foram realizados num fatorial $2 \times 2 \times 6$, metade e completa concentração de sais de MS, adição ou não de carvão ativado e seis concentrações do regulador de crescimento (NAA ou IBA), havendo transformação dos dados de percentagens por $\sqrt{x+0,5}$. 
Tabela 3. Tratamentos utilizados para enraizamento de gemas em meio básico MS com metade ou concentração completa dos sais, suplementado com NAA ou IBA nas concentrações de 0,0 a $5,0 \mu \mathrm{M}$.

\begin{tabular}{lcc}
\hline Meio básico & \multicolumn{2}{c}{ Regulador de crescimento } \\
\cline { 2 - 3 } & IBA $(\mu \mathrm{M})$ & NAA $(\mu \mathrm{M})$ \\
\hline 1/aMS & 0,0 & 0,0 \\
& 0,1 & 0,1 \\
& 0,5 & 0,5 \\
& 1,0 & 1,0 \\
2,5 & 2,5 \\
& 5,0 & 5,0 \\
& 0,0 & 0,0 \\
MS & 0,1 & 0,1 \\
& 0,5 & 0,5 \\
& 1,0 & 1,0 \\
& 2,5 & 2,5 \\
& 5,0 & 5,0 \\
\hline
\end{tabular}

\subsubsection{Aclimatação dos brotos enraizados e formação de mudas}

Os brotos enraizados ("plantlets") foram retirados dos frascos, lavados em água destilada para retirada de resíduo de meio de cultura, imersos em solução de benlate $0,2 \%$ por 20 minutos e transferidos para bandeja com substrato. Dois tipos de substratos foram testados: vermiculita e vermiculita + substrato comercial Plantmax na proporção de 1:1 (v/v). As bandejas contendo os "plantlets" foram mantidas sob câmara úmida durante 2 a 3 semanas, com umidade relativa do ar saturada, proporcionada por um umidificador elétrico. Após este período, os "plantlets" permaneceram em casa-de-vegetação em condições ambientais para posteriormente, 6 a 8 semanas, serem transferidos para sacos de polietileno preto $(16 \times 12 \mathrm{~cm}) \mathrm{com}$ substrato Plantmax e vermiculita na proporção 2:1 (v/v). Após a transferência, os "plantlets" sobreviventes foram mantidos em casa-de-vegetação ou telado para crescimento e formação de mudas, com nutrição mensal através da utilização de solução com metade da concentração de sais de MS. Nesta fase, os "plantlets" produzidos a partir de gemas nos dois últimos experimentos de enraizamento (Tabelas 2 e 3), sob condições de aclimatação, foram avaliados quanto a sobrevivência a partir de 21 dias nos diferentes tipos de substrato. Registrou-se o número de sobreviventes em relação ao total transferido e converteu-se em percentagem. $O$ teste qui-quadrado 
foi utilizado para avaliar a diferença entre os tipos de substrato e origem dos "planlets" quanto a aclimatação. Os "plantlets" aclimatados foram conduzidos à formação de mudas na casa-de-vegetação e nos telados.

\subsubsection{Assepsia de explantes provenientes de plantas propagadas via estacas}

A utilização de gemas e ápices caulinares a partir de plantas de pimenta-doreino crescidas no campo, até então, tem se mostrado ineficaz para o estabelecimento do processo de micropropagação desta cultura. Isto se deve principalmente à ocorrência de fungos e bactérias endógenas que inviabilizam o desenvolvimento das etapas de micropropagação. Após o estabelecimento das condições de micropropagação a partir de explantes provenientes de plântula in vitro, teve início o processo a partir de mudas propagadas vegetativamente, na casa-de-vegetação, como fonte doadora de explantes.

Material vegetativo contendo gemas axilares e apicais foi lavado em água corrente e detergente líquido neutro comercial, imersos em solução de benlate $(0,2 \%$ $\mathrm{p} / \mathrm{v}$ ) durante 20 minutos, lavado novamente e, na câmara de fluxo laminar asséptica, foi tratado com álcool 70\% (v/v) por 1 minuto, imersão em solução de hipoclorito de sódio ( $\mathrm{NaClO}$ ) $1 \%$ por 15 minutos, sendo enxaguado por no mínimo 4 vezes com água destilada esterilizada. Com o auxílio de lupa binocular, as gemas tratadas foram isoladas e introduzidas in vitro em meio básico de cultura MS, com adição de BAP a $0,1 \mathrm{mg} \cdot \mathrm{L}^{-1}$ e IAA a $0,2 \mathrm{mg} \cdot \mathrm{L}^{-1}$, e solução de antibióticos, num total de 4 tratamentos, como segue:

1. $\mathrm{MS}+\mathrm{BAP}$ a $0,1 \mathrm{mg} \cdot \mathrm{L}^{-1}+\mathrm{IAA}$ a $0,2 \mathrm{mg} \cdot \mathrm{L}^{-1}$ (Controle);

2. $\mathrm{MS}+\mathrm{BAP}$ a $0,1 \mathrm{mg} \cdot \mathrm{L}^{-1}+\mathrm{IAA}$ a $0,2 \mathrm{mg} \cdot \mathrm{L}^{-1}+$ Gentamicina a $250 \mathrm{mg} \cdot \mathrm{L}^{-1}$;

3. $\mathrm{MS}+\mathrm{BAP}$ a $0,1 \mathrm{mg} \cdot \mathrm{L}^{-1}+\mathrm{IAA}$ a $0,2 \mathrm{mg} \cdot \mathrm{L}^{-1}+$ Cefalexina a $250 \mathrm{mg} \cdot \mathrm{L}^{-1}$;

4. $\mathrm{MS}+\mathrm{BAP}$ a $0,1 \mathrm{mg} \cdot \mathrm{L}^{-1}+\mathrm{IAA}$ a $0,2 \mathrm{mg} \cdot \mathrm{L}^{-1}+$ Ampicilina a $160 \mathrm{mg} \cdot \mathrm{L}^{-1}$.

As soluções de antibióticos foram esterilizadas através de filtro estéril de $0,22 \mu \mathrm{m}$ com auxílio de bomba de vácuo e adicionadas aos meios de cultura autoclavados à $121^{\circ} \mathrm{C}$ durante 20 minutos. Após uma semana de cultivo, os explantes foram transferidos para meio de cultura suplementado com BAP $\left(0,5 \mathrm{mg} \cdot \mathrm{L}^{-1}\right)$ e IAA $(0,2$ mg. $\left.\mathrm{L}^{-1}\right)$ com carvão ativado $(0,2 \% \mathrm{p} / \mathrm{v})$ por 4 a 6 semanas antes de serem transferidos para mesmo meio de cultura sem carvão ativado. As avaliações quanto ao efeito dos tratamentos assépticos foram quanto a contaminação e oxidação dos explantes, e a 
análise dos dados foi feita através de um teste qui-quadrado, considerando sobrevivência e mortalidade.

\subsubsection{Multiplicação de plantas $\mathrm{V}_{5}$}

Sementes foram germinadas in vitro e, das plântulas obtidas, gemas foram retiradas e utilizadas para multiplicação. Neste caso, gemas de 12 linhagens de plantas $V_{5}$ foram multiplicadas, quais sejam: C26; N27; C45; C70; N121; C123; C132; N135; C137; C166; C170; e CT (cultivar Cingapura de estacas de plantas não irradiadas). Conforme condições de multiplicação de gemas preestabelecidas, gemas das linhagens foram introduzidas em meio básico de cultura MS suplementado com BAP $\left(0,5 \mathrm{mg} \cdot \mathrm{L}^{-1}\right)$ e IAA $\left(0,2 \mathrm{mg} \cdot \mathrm{L}^{-1}\right)$ e cultivados por 6 a 8 semanas em sala de luz. A avaliação foi quanto ao número de novas gemas por explante e os dados foram analisados em delineamento inteiramente casualizado, considerando 12 tratamentos (12 linhagens) e três repetições, sendo cada repetição representada pela média de diferenciação de novas gemas por explante em cada frasco contendo cinco gemas. Os dados foram submetidos às análises de variância e teste Duncan para comparação de médias.

\subsubsection{Indução de calos}

Para indução de calos, a partir de brotos in vitro, foram utilizados como explantes segmentos de entrenós e de folhas com pecíolo, e embriões zigóticos, em meio básico de cultura MS (Murashige \& Skoog, 1962) ou SH (Schenk \& Hildebrandt, 1972) suplementados com diferentes concentrações e combinações de dicamba, BAP,

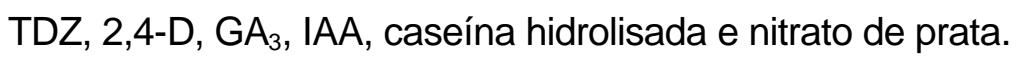

No primeiro experimento, segmentos de entrenós a partir de brotações desenvolvidas in vitro foram cultivados em meio SH suplementados com diferentes combinações de reguladores de crescimento (Tabela 4) e mantidos sob condições de B.O.D. ("Biological Oxygen Demand") com temperatura ajustada para $27^{\circ} \mathrm{C}$ e escuro, ou sala de crescimento com temperatura média de $25 \pm 3^{\circ} \mathrm{C}$ e fotoperíodo de 16h.luz.dia ${ }^{-1}$, de cerca de 3.000 lux proporcionada por três lâmpadas fluorescentes brancas de 20 watts (luz). Delineamento inteiramente casualizado, com cinco repetições, sendo cada uma representada por uma placa com cinco explantes. 
Tabela 4. Tratamentos para indução de calos a partir de segmentos de entrenós e de folha em meio de cultura básico SH suplementado com TDZ ou Dicamba combinado com BAP.

\begin{tabular}{|c|c|c|c|c|c|}
\hline \multirow{2}{*}{$\begin{array}{l}\text { TDZ } \\
(\mu \mathrm{M})\end{array}$} & \multicolumn{2}{|c|}{$\mathrm{BAP}(\mu \mathrm{M})$} & \multicolumn{2}{|c|}{$\mathrm{BAP}(\mu \mathrm{M})$} & \multirow{2}{*}{$\begin{array}{r}\text { Dicamba } \\
\qquad(\mu \mathrm{M})\end{array}$} \\
\hline & 0,0 & 1,0 & 0,0 & 1,0 & \\
\hline 0,1 & $x$ & $X$ & $x$ & $x$ & 5,0 \\
\hline 1,0 & $x$ & $X$ & $x$ & $x$ & 10,0 \\
\hline 5,0 & $x$ & $X$ & $x$ & $x$ & 20,0 \\
\hline
\end{tabular}

As avaliações foram realizadas aos 30 dias de cultivo através de explantes com indução de calos, sob as seguintes notações: 0 - sem calos; 1 - rara formação de calos; 2 baixa; 3 - moderada; e 4 - abundante, ou seja, explantes sem nenhuma desdiferenciação; com alguns pontos de desdiferenciação; desdiferenciação nas extremidades dos explantes; desdiferenciação ao longo de todo o explantes; e abundância de calos em todo o explante. A média para cada repetição foi calculada considerando a resposta de cada explante através da fórmula: $X=E_{1}+E_{2}+\ldots .+E_{n} / N$, e número de explantes com calo por total, convertido em percentagem. As médias foram submetidas æ̀̀ análises de variâncias em fatorial $2 \times 3 \times 2$, separadamente para as três concentrações de dicamba e as três concentrações de TDZ, e ao teste Tukey para comparação de médias.

No segundo experimento, testou-se somente em condições de escuro, segmentos de entrenós em meio básico SH suplementado com dicamba a 2,5 mg. $\mathrm{L}^{-1}$

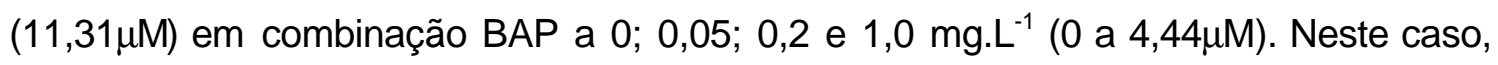
avaliou-se a indução de calos e o índice de oxidação, com a mesma notação empregada para a incidência de calos supracitada, cujas médias foram analisadas estatisticamente.

No terceiro experimento, testou-se o meio básico MS suplementado com dicamba a $2,0 \mathrm{mg} \cdot \mathrm{L}^{-1}(9,05 \mu \mathrm{M})$ e BAP a $0,2 \mathrm{mg} \cdot \mathrm{L}^{-1}(0,89 \mu \mathrm{M})$ e em combinação com ácido giberélico $\left(\mathrm{GA}_{3}\right)$ a $0,0,1,0,5,1,0$ e 5,0 mg. $\mathrm{L}^{-1}$ ou com nitrato de prata a 100, 200 e $400 \mathrm{mg} \cdot \mathrm{L}^{-1}$ tanto para entrenós quanto para segmentos de folha, em três repetições por tratamento, sendo cada repetição representada por uma placa com três a cinco explantes. As respostas quanto a indução de calos e oxidação foram avaliadas e as 
médias, para cada um desses parâmetros avaliados, foram submetidas æ̀̀ análises de variância e teste de comparação de médias.

No quarto experimento, avaliaram-se as respostas de segmentos de entrenós em meio básico SH suplementado com $20 \mu \mathrm{M}$ de dicamba em combinação com BAP (0 e $1,0 \mu \mathrm{M})$ e caseína hidrolisada a $500 \mathrm{mg} \cdot \mathrm{L}^{-1}$, num total de quatro tratamentos, que foram avaliados quanto a indução de calos e oxidação e no quinto experimento no mesmo meio de cultura mas com TDZ $(0,2,1,0,5,0$ e 10 $\mu \mathrm{M})$ em combinação com IAA $(0,1$ e $5 \mu \mathrm{M})$ e avaliados sob os mesmos parâmetros. Além desses, testou-se dicamba

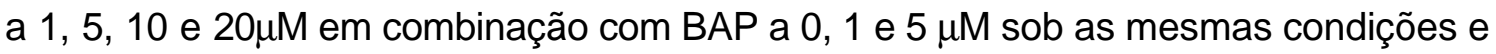
avaliações.

Ademais, testou-se embriões zigóticos como explante para indução de calos em meio básico de cultura SH semi-sólido, em placas de Petri (diâmetro 8,5 cm) com cerca de 35ml, suplementado com dicamba $(0 ; 1 ; 5$; e $10 \mu \mathrm{M})$ ou 2,4-D $(0 ; 1 ; 5$; e 10 $\mu \mathrm{M})$ em combinação com BAP $(0 ; 1$ e $5 \mu \mathrm{M})$. As avaliações foram quanto a indução de calos nos embriões, embriões sem resposta, diferenciados e necrosados. O teste quiquadrado foi usado para comparar as respostas quanto a indução de calos e não indução de calos dos efeitos das diferentes concentrações de dicamba e BAP.

Os calos formados foram transferidos para meio básico de cultura SH líquido suplementado com dicamba $(0 ; 1,13 ; 4,52$ e 11,31 $\mu \mathrm{M})$ e BAP $(1,0 \mu \mathrm{M})$ e cultivados sob agitação de cerca de 100 rpm ou meio básico MS semi-sólido (0,2\% phytagel) suplementado com TDZ (0; 0,1; 0,5; e 1,0 mg. $\left.\mathrm{L}^{-1}\right)$ combinado com BAP $\left(0\right.$ e 0,2 mg. $\left.\mathrm{L}^{-1}\right)$. No último caso, os calos foram cultivados em condições de fotoperíodo de 16.h.luz.dia ${ }^{1}$, com intensidade de luz de 3.000 lux e temperatura média de $25 \pm 3^{\circ} \mathrm{C}$.

As células em suspensão conseguidas foram mantidas em frascos erlenmeyers (capacidade $250 \mathrm{ml}$ ) com cerca de $50 \mathrm{ml}$ de meio líquido $\mathrm{SH}$ com 2,0 $\mathrm{mg} \cdot \mathrm{L}^{-1}$ de dicamba e BAP a $0,2 \mathrm{mg} \cdot \mathrm{L}^{-1}$ e refrescadas a cada trinta dias de cultura, sob agitação de 100 rpm e condições de escuro em temperatura média de $25 \pm 3^{\circ} \mathrm{C}$.

Outro teste foi realizado através da transferência de células mantidas em suspensão para meio básico SH semi-sólido (0,2\% phytagel) suplementado com BAP $(1 \mu \mathrm{M})$ e sacarose nas concentrações de 1,0, 1,5 e 3,0\% sob condições de cultivo supracitadas, visando a diferenciação de embriões somáticos. 


\subsection{Mutagênese e seleção de variantes contra a doença fusariose}

Nesta etapa foram realizados testes de radiossensitividade de gemas in vitro a radiação gama a diferentes doses; cultivo do fungo Fusarium solani $f$. sp. piperis e testes de diferentes concentrações e forma de esterilização do filtrado da cultura como agente seletivo em cultivo in vitro de gemas de plantas susceptíveis em meio de multiplicação; seleção in vitro de variantes, sobreviventes ao agente seletivo, provenientes do tratamento de gemas com radiação gama; e testes de concentrações e modos de aplicação de suspensão de esporos do fungo para causar $100 \%$ de mortalidade de gemas in vitro das plantas susceptíveis àdoença fusariose.

\subsubsection{Radiossensitividade de gemas in vitro à radiação gama}

Inicialmente foram realizadas irradiações em gemas, de plantas micropropagadas, em placas de Petri plásticas estéreis (diâm. 8,5cm) com pelo menos 20 gemas por placa, nas doses de 0 a 80 Gy a partir da fonte de ${ }^{60} \mathrm{Co}$ de "Gammacell", CENA/USP com taxas de dose que variaram de 1,648 a 1,387 kGy. $\mathrm{h}^{-1}$, cujos tempos de irradiação e número de gemas irradiadas em cada dose e taxa de dose estão apresentadas na Tabela 5. Após a irradiação das gemas em meio básico de cultura MS semi-sólido (0,7\% phytagel) sem reguladores de crescimento, estas foram transferidas para frasco com meio básico de cultura MS suplementado com 1,5 ou 0,5 mg. $\mathrm{L}^{-1}$ de BAP, antes da determinação das condições mais adequadas de micropropagação. Os explantes sobreviventes continuaram a ser multiplicados a cada 6 a 8 semanas de subcultivo, durante pelo menos três subcultivos, até serem transferidos para seleção in vitro em meio seletivo ou para enraizamento, aclimatação e formação mudas. 
Tabela 5. Tempo de irradiação de gemas, nas diferentes doses de radiação gama de acordo com a taxa de dose da fonte de ${ }^{60} \mathrm{Co}$ de "Gammacell", CENA/USP.

\begin{tabular}{|c|c|c|c|c|c|c|c|c|c|c|c|c|c|}
\hline \multirow{3}{*}{$\begin{array}{l}\text { Dose } \\
\text { (Gy) }\end{array}$} & \multicolumn{12}{|c|}{ Taxa de dose (kGy. $\left.h^{-1}\right)$} & \multirow{3}{*}{ Total } \\
\hline & \multicolumn{2}{|c|}{1,648} & \multicolumn{2}{|c|}{1,579} & \multicolumn{2}{|c|}{1,545} & \multicolumn{2}{|c|}{1,527} & \multicolumn{2}{|c|}{1,405} & \multicolumn{2}{|c|}{1,387} & \\
\hline & Gema & min:s & gema & min:s & gema & min:s & gema & min:s & gema & min:s & gema & min:s & \\
\hline 0 & - & - & 54 & - & 7 & - & 100 & - & - & - & - & - & 161 \\
\hline 10 & 10 & $0: 21$ & 54 & $0: 22$ & 14 & $0: 23$ & 100 & $0: 23$ & - & - & - & - & 178 \\
\hline 20 & 10 & $0: 43$ & 54 & $0: 45$ & 9 & $0: 46$ & 100 & $0: 47$ & 50 & $0: 51$ & 40 & $0: 51$ & 263 \\
\hline 30 & 10 & $1: 05$ & 54 & $1: 08$ & 14 & $1: 09$ & 100 & $1: 10$ & 50 & $1: 16$ & 40 & $1: 17$ & 268 \\
\hline 40 & 10 & $1: 27$ & 54 & $1: 31$ & 6 & $1: 33$ & 100 & $1: 34$ & 50 & $1: 42$ & 40 & $1: 43$ & 260 \\
\hline 60 & - & - & - & - & - & - & 100 & $2: 21$ & 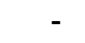 & - & 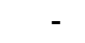 & - & 100 \\
\hline 80 & 10 & $2: 54$ & - & - & - & - & - & & - & - & - & - & 10 \\
\hline Total & 50 & & 270 & & 50 & & 600 & & 150 & & 120 & & 1079 \\
\hline
\end{tabular}

Considerando as observações anteriores dos efeitos da radiação e tendo estabelecido condições adequadas de multiplicação das gemas, foi instalado um experimento em delineamento inteiramente casualizado com cinco tratamentos (doses 0, 20, 30, 40 e 50 Gy) e sete repetições, sendo constituída cada repetição de 20 gemas por placa, num total de 700 gemas. Cada placa contendo agar-água $(0,7 \% \mathrm{p} / \mathrm{v}) \mathrm{com}$ as vinte gemas foi irradiada individualmente, conforme a taxa de dose de 1,297KGy. $\mathrm{h}^{-1}$. Após a irradiação das gemas (Figura 4), dez gemas de cada repetição foram transferidas para dois frascos cilíndricos com capacidade de $300 \mathrm{ml}$ e com $50 \mathrm{ml}$ de meio básico de cultura MS semi-sólido suplementado com BAP $\left(0,5 \mathrm{mg} \cdot \mathrm{L}^{-1}\right)$ e IAA $(0,2$ mg. $\left.\mathrm{L}^{-1}\right)$. Após 45 dias de cultivo sob condições de fotoperíodo 16h.luz.dia ${ }^{-1}$, temperatura de $25 \pm 3^{\circ} \mathrm{C}$ e intensidade de iluminação de cerca de 3.000 lux, avaliou-se a taxa de sobrevivência, número de gemas por explante e peso do explante (g). As médias foram submetidas æ̀s análises de regressão linear para a determinação da dose de radiação gama necessária para redução a 70 e 50\% da taxa de sobrevivência, número de gemas e peso dos explantes através do programa Excel. 


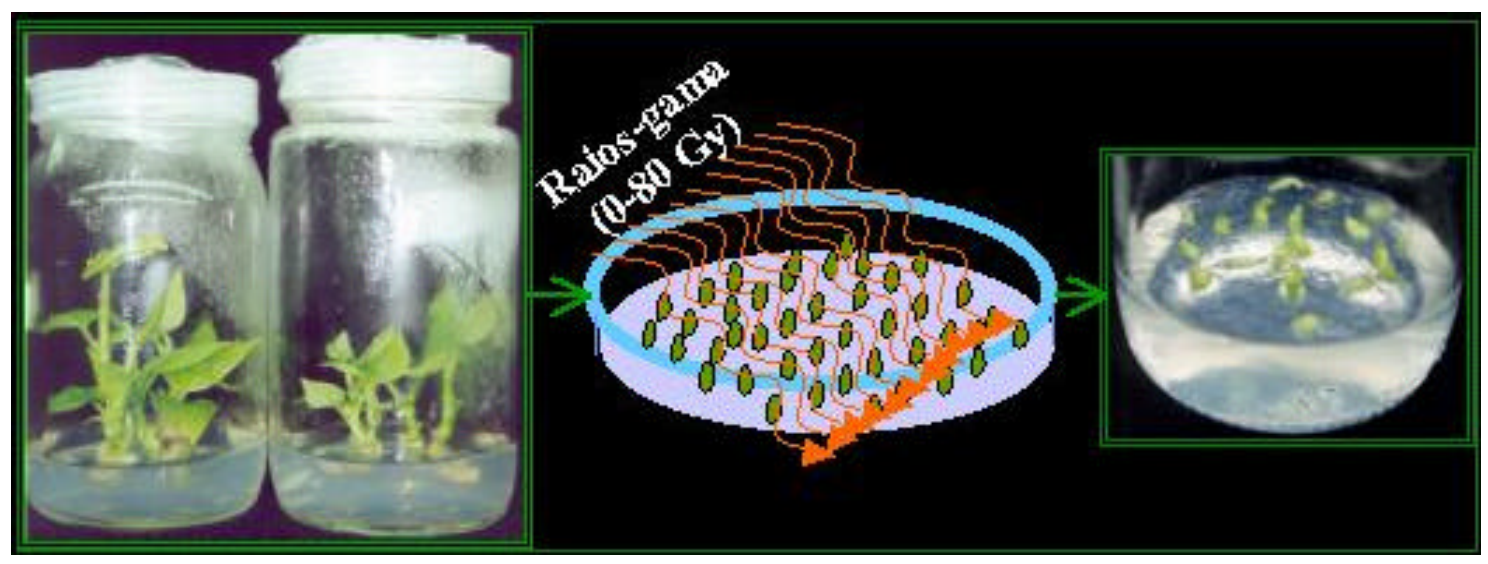

Figura 4 - Teste de radiosensitividade de gemas in vitro com doses de radiação gama de 0 a 80 Gy e cultivo em meio de multiplicação de gemas.

Uma vez definida a dose de 20 Gy de irradiação gama como a mais apropriada, segundo os efeitos fisiológicos e padrões preestabelecidos, 1.024 gemas de plantas susceptíveis àdoença fusariose cultivadas in vitro foram submetidas a esta dose de irradiação, e após cerca de 7 semanas de cultivo, sob as mesmas condições preestabelecidas para multiplicação de gemas, foram avaliadas quanto a sobrevivência e o número de diferenciação de novas gemas por explante irradiado.

\subsubsection{Fitotoxicidade in vitro do filtrado de cultura do fungo Fusarium solani . sp. piperis a gemas}

Para determinar a influência dos compostos de Czapek Dox em meio de cultura de multiplicação - meio básico de cultura MS suplementado com BAP $\left(0,5 \mathrm{mg} \cdot \mathrm{L}^{-}\right.$ $\left.{ }^{1}\right)$ e IAA $\left(0,2 \mathrm{mg} \cdot \mathrm{L}^{-1}\right)$ - sobre a performance das gemas in vitro, foi realizado um teste com diferentes concentrações de Czapek Dox (0, 20, 30, 40 e 50\% v/v) no meio de multiplicação de gemas. O teste foi instalado em delineamento inteiramente casualizado, três repetições, sendo cada repetição representado por um frasco com cinco gemas. Dados foram registrados quanto a sobrevivência dos explantes e ao número de gemas por explante após 45 dias de cultivo, os quais foram submetidos æ̀s análises de variância e teste Tukey para comparação de médias.

Por outro lado, isolados do fungo Fusarium solani $f$. sp. piperis obtidos de plantas de pimenta-do-reino atacadas em áreas de cultivo do Município de Tomé-Açu, Estado do Pará, cedidos pelo Laboratório de Fitopatologia da Embrapa Amazônia 
Oriental, Belém, Estado do Pará, foram cultivados em meio de cultura BSA (Batatasacarose-agar) (Anexo G). Após duas semanas, discos de $1 \mathrm{~cm}$ com micélio do fungo foram transferidos para meio de cultura de Czapek-Dox, sendo um disco para cada 200 $\mathrm{ml}$ de meio. Primeiramente, três frascos com $200 \mathrm{ml}$ de meio de Czapek-Dox e um disco por frasco foram cultivados durante 35 dias e as observações quanto ao número de macro e micro conídios por $\mathrm{ml}$ foram realizadas aos 8, 11, 14, 17, 23, 29 e 35 dias de cultivo, e no final do período, as hifas obtidas foram secas em estufa a $40^{\circ} \mathrm{C}$ durante $48 \mathrm{~h}$ e pesadas. Uma curva de crescimento foi obtida com os dados através do programa Excel.

Considerando os resultados obtidos acima, novas culturas foram realizadas e, a partir de 23 a 28 dias, filtrados foram obtidos através da filtragem e esterilização da cultura. Para testar a fitotoxicidade do filtrado, um experimento com filtrado proveniente de 28 dias de cultivo do fungo a diferentes concentrações $(0,20,30,40$ e $50 \% \mathrm{v} / \mathrm{v})$ em meio de cultura básico MS suplementado com BAP $\left(0,5 \mathrm{mg}^{\mathrm{L} \mathrm{L}^{-1}}\right)$ e IAA $\left(0,2 \mathrm{mg} \cdot \mathrm{L}^{-1}\right)$ meio de multiplicação de gemas- e duas formas de esterilização do filtrado, foram testadas. A primeira forma de esterilização foi através de filtro estéril de 0,22 $\mu \mathrm{m}$ em câmara de fluxo laminar asséptica com auxílio de bomba de vácuo e adição ao meio de multiplicação de gemas autoclavado, em câmara de fluxo laminar asséptica (FE); e a segunda, o filtrado da cultura do fungo foi autoclavado por 20 minutos, adicionado na concentração desejada ao meio de multiplicação de gemas para novamente sofrer autoclavagem (All). Para cada tratamento, foram utilizadas duas repetições, sendo cada repetição representada por cinco gemas. A avaliação foi realizada quanto a percentagem de mortalidade das gemas. Os dados foram submetidos à análises de variância, teste Tukey para comparação de médias e análise de regressão linear.

\subsubsection{Seleção in vitro de variantes sobreviventes ao filtrado da cultura do fungo}

As gemas que foram submetidas à irradiação gama e sobreviveram, passaram por vários ciclos de multiplicação através do cultivo em meio de multiplicação, visando a eliminação de quimerismo e obtenção de variantes com tecidos homogêneos. Por conseguinte, poderão ser gerados mutantes do tipo periclinal e/ou do tipo sólido, antes de serem submetidos à seleção in vitro em meio de cultura com agente seletivo, filtrado da cultura do fungo à concentração de $50 \%$, e $55 \%$ do 
filtrado All obtido aos 28 dias de cultivo do fungo em meio Czapek-Dox sob cultivo normal ou co-cultivo (Figura 5).

O fungo sob cultivo normal caracterizou-se pela transferência de um disco de micélio do fungo crescido em BSA durante duas semanas para cada $200 \mathrm{ml}$ de Czapek Dox, enquanto sob co-cultivo, o fungo foi crescido sob as mesmas condições anteriores, mas junto com plantas in vitro de pimenta-do-reino, sendo uma planta para cada $100 \mathrm{ml}$. Um total de 4.117 gemas foi submetido à seleção in vitro, sendo as gemas provenientes da irradiação à dose de 10,20, 30 e 40Gy, respectivamente 2.332, 532, 160 e 1.093 gemas. As avaliações foram quanto ao número de gemas sobreviventes e mortas de cada dose aos tratamentos relativos ao filtrado. Os dados foram convertidos em percentagens de seleção e comparações através de testes de qui-quadrado quanto ao índice de seleção para cada condições do agente seletivo empregado ao meio de seleção.

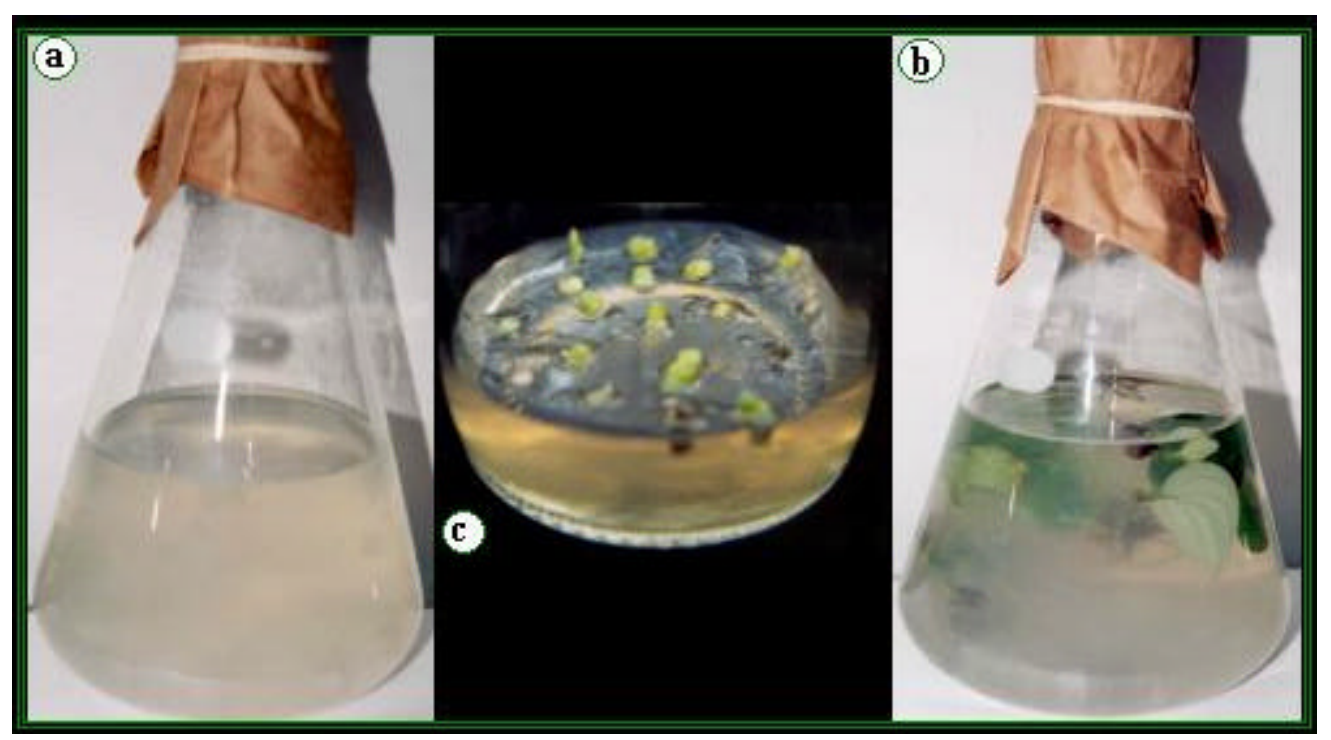

Figura 5 - Obtenção de filtrado e gemas em meio seletivo.

a) Fungo sob cultivo normal

b) Fungo em co-cultivo com plantas de pimenta-do-reino

c) Gemas em seleção in vitro com agente seletivo filtrado de cultura do fungo

\subsubsection{Determinação da concentração de esporos e modo de inoculação}

Plantas susceptíveis de pimenta-do-reino em sacos de polietileno preto em casa-de-vegetação foram inoculadas a diferentes concentrações do fungo $\left(0 ; 2 \times 10^{2}\right.$; $2 \times 10^{4}$ e $2 \times 10^{6}$ esporos $/ \mathrm{ml}$ ) no solo ou na parte aérea (Figura 6). Para cada 
concentração, foram utilizados $5 \mathrm{ml}$ do inóculo, sendo cinco plantas por tratamento. $\mathrm{O}$ fungo foi cultivado em meio de cultura BSA (batata-sacarose-agar) durante duas semanas, sendo os esporos coletados com água estéril através da passagem por gazes e contados em câmara de Neubauer, cujas concentrações desejadas foram ajustadas. As mudas utilizadas foram provenientes de cultura de tecidos com cerca de seis meses após a aclimatação e a inoculação foi realizada através de um spray inoculação na parte aérea - e adição na base da planta - inoculação no solo. As avaliações foram visuais quanto a mortalidade das mudas a partir de dois meses após a inoculação e re-isolamento do patógeno para confirmação dos sintomas causados pela ação do patógeno através da realização do postulado de Koch.

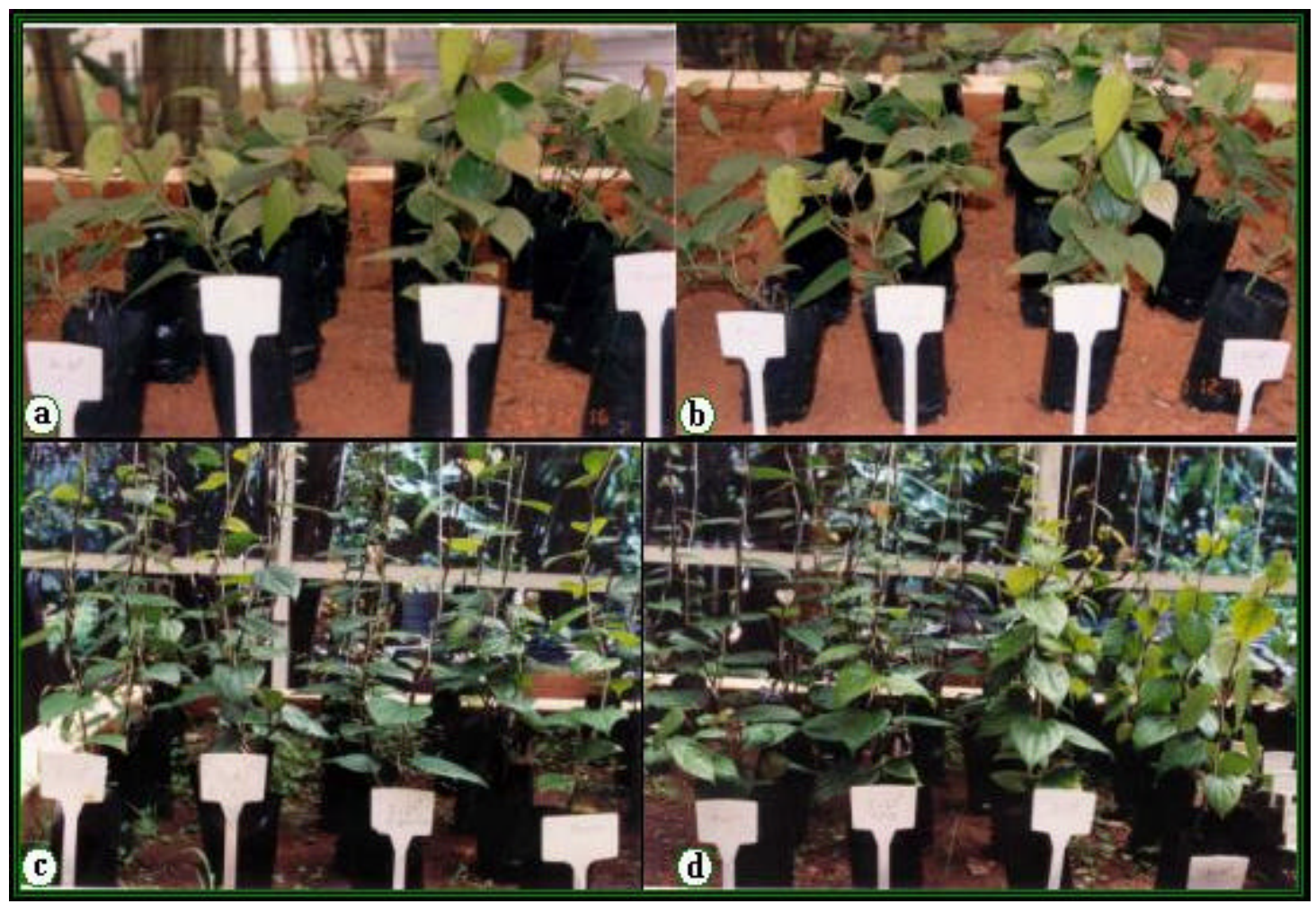

Figura 6 - Experimento para a determinação do modo de aplicação e concentração da suspensão de esporos.

a) Plantas antes da inoculação com spray na parte aérea

b) Plantas antes da inoculação no solo

c) Plantas com dois meses após a inoculação com spray na parte aérea

d) Plantas com dois meses a inoculação no solo 


\subsection{Avaliação agronômica de plantas oriundas de estacas tratadas com irradiação gama}

As linhagens selecionadas foram obtidas de um experimento iniciado em 1978 (Ando et al., 1984). Provenientes da cultivar Cingapura 428 estacas foram submetidas à irradiação gama nas doses de 20 e 25 Gy na fonte de raios-gama ${ }^{60} \mathrm{Co}$, do CENA/USP, Piracicaba, São Paulo, e plantadas em campo de experimento em área recém desmatada do Instituto de Experimento Agrícola Tropical da Amazônia (INATAM), JICA ("Japan International Cooperation Agency”), no Município de Tomé Açu, Estado do Pará, plantas sobreviventes se desenvolveram para produção de mudas $V_{1}$. Nas plantas $V_{1}$, com desenvolvimento normal no campo, foram realizadas podas e as estacas, no total de 500 com dois e três nós, originaram plantas da geração $\mathrm{V}_{2}$, que foram conduzidas individualmente em baldes plásticos de $5 \mathrm{~L}$ com substrato composto de solo e, aos três meses após o plantio, houve inoculação com isolados do fungo Fusarium solani f. sp. piperis, crescidos em BSA por 15 a 20 dias, na concentração de $5 \times 10^{4}$ esporos por $\mathrm{ml}$, no solo, na proporção de $10 \mathrm{ml}$ por balde. As

plantas sobreviventes $V_{2}$ (43 plantas) foram transplantadas para área de alta incidência da doença visando a seleção natural. Três plantas sobreviveram nessas condições após três anos de cultivo, a partir das quais plantas $V_{3}$ foram produzidas e ensaios preliminares de caracterização dos materiais foram iniciados. Das plantas $V_{3}$ aos quatro anos de cultivo com melhores desempenhos quanto a incidência da doença, vigor de crescimento, formato e produtividade de sementes, foram produzidas plantas $\mathrm{V}_{4}$, das quais, com melhores performances em campo, avaliadas por produtores $\mathrm{e}$ técnicos após cinco anos de cultivo, foram produzidas linhagens de plantas $V_{5} \mathrm{e}$ posteriormente, plantas $V_{6}$ que foram plantadas em área do mesmo Município da Associação Fomento agrícola de ToméAçu (ASFATA), (Figura 7). 
$\underline{\text { ANO }}$

$\underline{\text { LOCAL }}$

GERAÇÃO

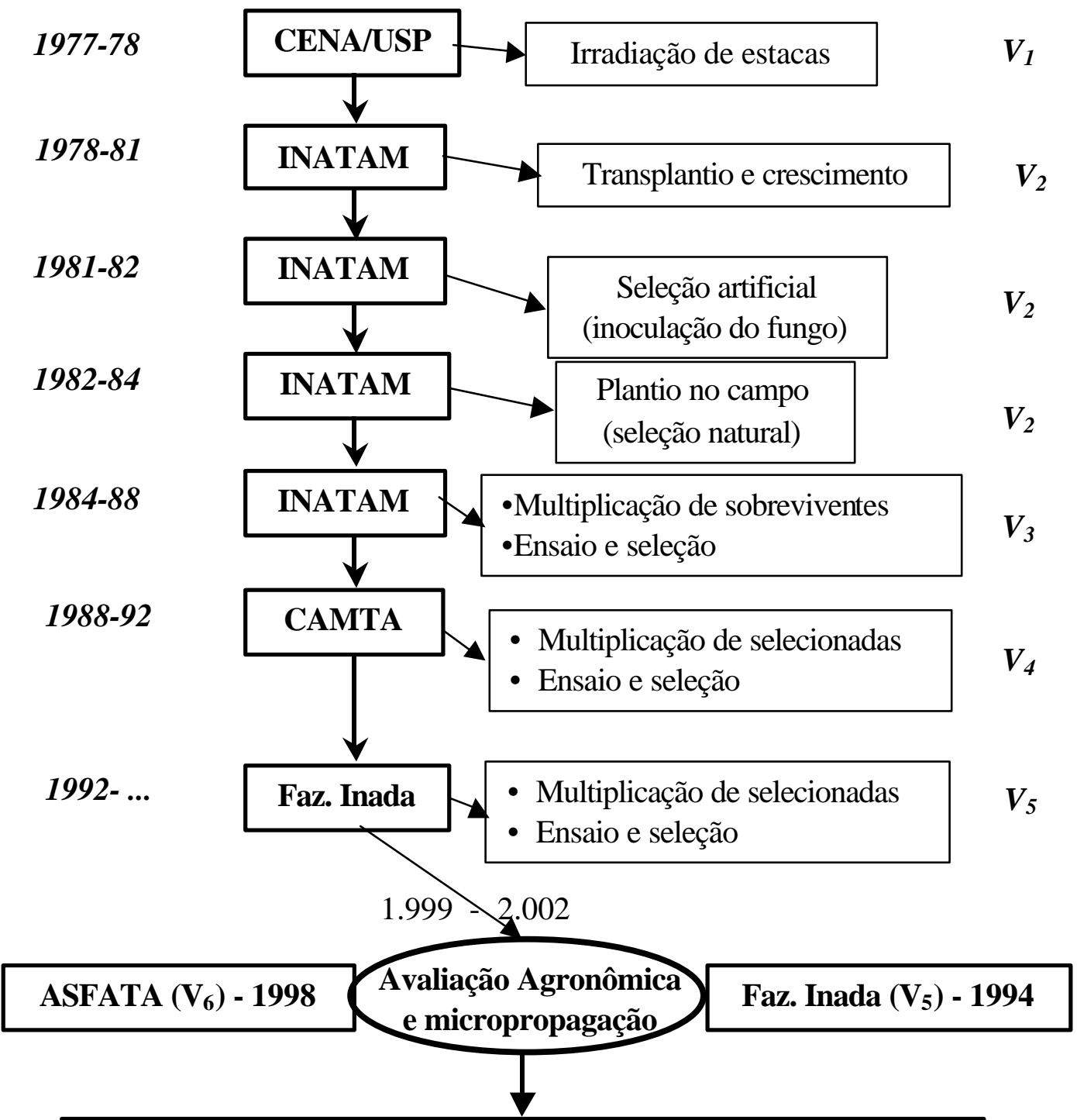

Clonagem e seleção in vitro e in vivo das progênies contra o fungo

Figura 7 - Metodologia adotada para seleção de linhagens tolerantes à doença fusariose a partir da irradiação gama em estacas de pimenta-do-reino, avaliação agronômica, micropropagação e seleção de progênies contra o fungo. 


\subsubsection{Avaliação agronômica em plantas $\mathbf{V}_{5}$}

$O$ experimento para avaliação de plantas $V_{5}$ quanto aos caracteres agronômicos foi instalado em março de 1994, em área de um produtor de pimenta-doreino (Sr. Inada) com ocorrência natural da doença fusariose, no Município de ToméAçu, Estado do Pará. As 16 linhagens $V_{5}$ selecionadas, oriundas da irradiação gama em estacas, e uma linhagem de estacas não irradiadas, cultivar Cingapura, foram conduzidas no campo, constituindo-se de 8 plantas cada repetição, cujo número de repetições por linhagem variou de 1 a 7 (Figura 8).

Todas as linhagens $V_{5}$ foram avaliadas quanto a incidência da doença fusariose e sobrevivência, comprimento e peso da espiga, número de sementes por espiga, peso úmido e seco de 100 frutos, e produção por planta. Além disso, foi observado o período de floração das plantas, número de ramos ortotrópicos e plagiotrópicos.

De cada planta $V_{5}$, foram coletadas 10 espigas, das quais foram registrados os comprimentos, números de frutos por espiga, pesos da espiga, e pesos de 100 frutos úmidos e secos. A coleta das espigas foi feita de forma aleatória, mas de modo a tomar espigas de todos os lados da planta. A secagem dos 100 frutos foi realizada em estufa a $40^{\circ} \mathrm{C}$ durante $48 \mathrm{~h}$. Os ramos ortotrópicos e plagiotrópicos foram contados das plantas sobreviventes na última avaliação.

Médias e variação das variáveis foram obtidas, Teste Tukey de comparação de médias foi realizado considerando três anos de avaliação quanto aos caracteres de produção, e análises de divergência genética através de componentes principais e variáveis canônicas foram realizadas. 


\begin{tabular}{|c|c|c|c|c|c|c|c|c|c|c|c|}
\hline $\bar{X}$ & $\mathbf{X}$ & $\mathbf{X}$ & $\mathbf{X}$ & $\mathbf{X}$ & $\mathbf{X}$ & $\mathbf{X}$ & $\mathbf{X}$ & $\mathbf{X}$ & $\mathbf{X}$ & $\mathbf{X}$ & $\mathbf{X}$ \\
\hline $\mathbf{X}$ & $\mathbf{X}$ & $\mathbf{X}$ & $\mathbf{X}$ & $\mathbf{X}$ & $\mathbf{X}$ & $\mathbf{X}$ & $\mathbf{X}$ & $\mathbf{X}$ & $\mathbf{X}$ & $\mathbf{X}$ & $\mathbf{X}$ \\
\hline $\mathbf{X}$ & $\mathbf{X}$ & $\mathbf{X}$ & $\mathbf{X}$ & $\mathbf{X}$ & $\mathbf{X}$ & $\mathbf{X}$ & $\mathbf{X}$ & $\mathbf{X}$ & $\mathbf{X}$ & $\mathbf{X}$ & $\mathbf{X}$ \\
\hline$\overline{\mathrm{O}}$ & $\bar{O}$ & $\mathrm{O}$ & $\mathrm{O}$ & $\mathrm{O}$ & $\mathrm{O}$ & $\bar{O}$ & $\mathrm{O}$ & $\mathrm{O}$ & $\bar{O}$ & $\mathrm{O}$ & $\mathrm{O}$ \\
\hline $\mathrm{O}$ & $\mathrm{O}$ & $\mathrm{O}$ & $\mathrm{O}$ & $\mathrm{O}$ & $\mathrm{O}$ & $\mathrm{O}$ & $\mathrm{O}$ & $\mathrm{O}$ & $\mathrm{O}$ & $\mathrm{O}$ & $\mathrm{O}$ \\
\hline $\mathrm{O}$ & $\mathrm{O}$ & $\mathrm{O}$ & $\mathrm{O}$ & $\mathrm{O}$ & $\mathrm{O}$ & $\mathrm{O}$ & $\mathrm{O}$ & $\mathrm{O}$ & $\mathrm{O}$ & $\mathrm{O}$ & $\mathrm{O}$ \\
\hline $\mathrm{O}$ & $\mathrm{O}$ & $\mathrm{O}$ & $\mathrm{O}$ & $\mathrm{O}$ & $\mathrm{O}$ & $\mathrm{O}$ & $\mathrm{O}$ & $\mathrm{O}$ & $\mathrm{O}$ & $\mathrm{O}$ & $\mathrm{O}$ \\
\hline $\mathrm{O}$ & $\mathrm{O}$ & $\mathrm{O}$ & $\mathrm{O}$ & $\mathrm{O}$ & $\mathrm{O}$ & $\mathrm{O}$ & $\mathrm{O}$ & $\mathrm{O}$ & $\mathrm{O}$ & $\mathrm{O}$ & $\mathrm{O}$ \\
\hline $\mathrm{O}$ & $\mathrm{O}$ & $\mathrm{O}$ & $\mathrm{O}$ & $\mathrm{O}$ & $\mathrm{O}$ & $\mathrm{O}$ & $\mathrm{O}$ & $\mathrm{O}$ & $\mathrm{O}$ & $\mathrm{O}$ & $\mathrm{O}$ \\
\hline O C-3 & O C-1 & O C-3 & O C-3 & O C-3 & O C-1 & O C-3 & O N-1 & O C-3 & O N-3 & O C-1 & O C-1 \\
\hline O 70 & O 45 & O 170 & O 123 & O 132 & O 163 & OT & OA & O 166 & O 148 & O 137 & O 25 \\
\hline $\bar{X}$ & $\mathbf{X}$ & $\mathbf{X}$ & $\bar{X}$ & $\bar{X}$ & $\mathbf{X}$ & $\mathbf{X}$ & $\mathbf{X}$ & $\mathbf{X}$ & $\mathbf{X}$ & $\bar{X}$ & $\mathbf{X}$ \\
\hline $\mathrm{O}$ & $\mathrm{O}$ & $\mathrm{O}$ & $\bar{O}$ & $\mathrm{O}$ & $\mathrm{O}$ & $\bar{O}$ & $\mathrm{O}$ & $\mathrm{O}$ & $\bar{O}$ & $\mathrm{O}$ & $\bar{O}$ \\
\hline $\mathrm{O}$ & $\mathrm{O}$ & $\mathrm{O}$ & $\mathrm{O}$ & $\mathrm{O}$ & $\mathrm{O}$ & $\mathrm{O}$ & $\mathrm{O}$ & $\mathrm{O}$ & $\mathrm{O}$ & $\mathrm{O}$ & $\mathrm{O}$ \\
\hline $\mathrm{O}$ & $\mathrm{O}$ & $\mathrm{O}$ & $\mathrm{O}$ & $\mathrm{O}$ & $\mathrm{O}$ & $\mathrm{O}$ & $\mathrm{O}$ & $\mathrm{O}$ & $\mathrm{O}$ & $\mathrm{O}$ & $\mathrm{O}$ \\
\hline $\mathrm{O}$ & $\mathrm{O}$ & $\mathrm{O}$ & $\mathrm{O}$ & $\mathrm{O}$ & $\mathrm{O}$ & $\mathrm{O}$ & $\mathrm{O}$ & $\mathrm{O}$ & $\mathrm{O}$ & $\mathrm{O}$ & $\mathrm{O}$ \\
\hline $\mathrm{O}$ & $\mathrm{O}$ & $\mathrm{O}$ & $\mathrm{O}$ & $\mathrm{O}$ & $\mathrm{O}$ & $\mathrm{O}$ & $\mathrm{O}$ & $\mathrm{O}$ & $\mathrm{O}$ & $\mathrm{O}$ & $\mathrm{O}$ \\
\hline $\mathrm{O}$ & $\mathrm{O}$ & $\mathrm{O}$ & $\mathrm{O}$ & $\mathrm{O}$ & $\mathrm{O}$ & $\mathrm{O}$ & $\mathrm{O}$ & $\mathrm{O}$ & $\mathrm{O}$ & $\mathrm{O}$ & $\mathrm{O}$ \\
\hline O C-3 & O C-1 & O C-1 & O C-3 & O C-1 & O C-1 & O C-3 & O N-2 & O N-2 & O C-1 & O C-1 & O N-1 \\
\hline O 123 & O 166 & O 26 & O 163 & O 26 & O 123 & O 26 & O 108 & O 27 & O T & O 132 & OA \\
\hline $\bar{X}$ & $\mathbf{X}$ & $\bar{X}$ & $\mathbf{X}$ & $\mathbf{X}$ & $\mathbf{X}$ & $\mathbf{X}$ & $\mathbf{X}$ & $\mathbf{X}$ & $\mathbf{X}$ & $\bar{X}$ & $\mathbf{X}$ \\
\hline$\overline{\mathrm{O}}$ & $\bar{O}$ & $\mathrm{O}$ & $\overline{\mathrm{O}}$ & $\mathrm{O}$ & $\mathrm{O}$ & $\bar{O}$ & $\mathrm{O}$ & $\mathrm{O}$ & $\overline{\mathrm{O}}$ & $\mathrm{O}$ & $\mathrm{O}$ \\
\hline $\mathrm{O}$ & $\mathrm{O}$ & $\mathrm{O}$ & $\mathrm{O}$ & $\mathrm{O}$ & $\mathrm{O}$ & $\mathrm{O}$ & $\mathrm{O}$ & $\mathrm{O}$ & $\mathrm{O}$ & $\mathrm{O}$ & $\mathrm{O}$ \\
\hline $\mathrm{O}$ & $\mathrm{O}$ & $\mathrm{O}$ & $\mathrm{O}$ & $\mathrm{O}$ & $\mathrm{O}$ & $\mathrm{O}$ & $\mathrm{O}$ & $\mathrm{O}$ & $\mathrm{O}$ & $\mathrm{O}$ & $\mathrm{O}$ \\
\hline $\mathrm{O}$ & $\mathrm{O}$ & $\mathrm{O}$ & $\mathrm{O}$ & $\mathrm{O}$ & $\mathrm{O}$ & $\mathrm{O}$ & $\mathrm{O}$ & $\mathrm{O}$ & $\mathrm{O}$ & $\mathrm{O}$ & $\mathrm{O}$ \\
\hline $\mathrm{O}$ & $\mathrm{O}$ & $\mathrm{O}$ & $\mathrm{O}$ & $\mathrm{O}$ & $\mathrm{O}$ & $\mathrm{O}$ & $\mathrm{O}$ & $\mathrm{O}$ & $\mathrm{O}$ & $\mathrm{O}$ & $\mathrm{O}$ \\
\hline $\mathrm{O}$ & $\mathrm{O}$ & $\mathrm{O}$ & $\mathrm{O}$ & $\mathrm{O}$ & $\mathrm{O}$ & $\mathrm{O}$ & $\mathrm{O}$ & $\mathrm{O}$ & $\mathrm{O}$ & $\mathrm{O}$ & $\mathrm{O}$ \\
\hline O C-3 & O C-1 & O C-3 & O C-3 & O C-1 & O C-2 & O C-3 & O C-3 & O N-1 & O N-2 & O C-1 & O C-1 \\
\hline O 163 & O 170 & O T & O 166 & O 70 & O 163 & O 137 & O 170 & O 135 & O 121 & O 70 & O 166 \\
\hline $\bar{X}$ & $\mathbf{X}$ & $\bar{X}$ & $\bar{X}$ & $\mathbf{X}$ & $\bar{X}$ & $\mathbf{X}$ & $\mathbf{X}$ & $\mathbf{X}$ & $\mathbf{X}$ & $\bar{X}$ & $\mathbf{X}$ \\
\hline $\mathrm{O}$ & $\mathrm{O}$ & $\overline{\mathrm{O}}$ & $\overline{\mathrm{O}}$ & $\mathrm{O}$ & $\mathrm{O}$ & $\bar{O}$ & $\bar{O}$ & $\mathrm{O}$ & $\bar{O}$ & $\mathrm{O}$ & $\mathrm{O}$ \\
\hline $\mathrm{O}$ & $\mathrm{O}$ & $\mathrm{O}$ & $\mathrm{O}$ & $\mathrm{O}$ & $\mathrm{O}$ & $\mathrm{O}$ & $\mathrm{O}$ & $\mathrm{O}$ & $\mathrm{O}$ & $\mathrm{O}$ & $\mathrm{O}$ \\
\hline $\mathrm{O}$ & $\mathrm{O}$ & $\mathrm{O}$ & $\mathrm{O}$ & $\mathrm{O}$ & $\mathrm{O}$ & $\mathrm{O}$ & $\mathrm{O}$ & $\mathrm{O}$ & $\mathrm{O}$ & $\mathrm{O}$ & $\mathrm{O}$ \\
\hline $\mathrm{O}$ & $\mathrm{O}$ & $\mathrm{O}$ & $\mathrm{O}$ & $\mathrm{O}$ & $\mathrm{O}$ & $\mathrm{O}$ & $\mathrm{O}$ & $\mathrm{O}$ & $\mathrm{O}$ & $\mathrm{O}$ & $\mathrm{O}$ \\
\hline $\mathrm{O}$ & $\mathrm{O}$ & $\mathrm{O}$ & $\mathrm{O}$ & $\mathrm{O}$ & $\mathrm{O}$ & $\mathrm{O}$ & $\mathrm{O}$ & $\mathrm{O}$ & $\mathrm{O}$ & $\mathrm{O}$ & $\mathrm{O}$ \\
\hline $\mathrm{O}$ & $\mathrm{O}$ & $\mathrm{O}$ & $\mathrm{O}$ & $\mathrm{O}$ & $\mathrm{O}$ & $\mathrm{O}$ & $\mathrm{O}$ & $\mathrm{O}$ & $\mathrm{O}$ & $\mathrm{O}$ & $\mathrm{O}$ \\
\hline O C-3 & O C-3 & O C-1 & O C-3 & O C-3 & O C-1 & O C-3 & O C-3 & O N-2 & O C-3 & O C-1 & O C-1 \\
\hline O 70 & O 132 & O 25 & O 70 & O 137 & O 26 & O 166 & O 70 & О 108 & O 166 & O 45 & O 163 \\
\hline $\bar{X}$ & $\mathbf{X}$ & $\mathbf{X}$ & $\mathbf{X}$ & $\mathbf{X}$ & $\mathbf{X}$ & $\mathbf{X}$ & $\mathbf{X}$ & $\mathbf{X}$ & $\mathbf{X}$ & $\mathbf{X}$ & $\mathbf{X}$ \\
\hline $\mathrm{O}$ & $\mathrm{O}$ & $\mathrm{O}$ & $\mathrm{O}$ & $\mathrm{O}$ & $\mathrm{O}$ & $\mathrm{O}$ & $\mathrm{O}$ & $\mathrm{O}$ & $\mathrm{O}$ & $\mathrm{O}$ & $\mathrm{O}$ \\
\hline $\mathrm{O}$ & $\mathrm{O}$ & $\mathrm{O}$ & $\mathrm{O}$ & $\mathrm{O}$ & $\mathrm{O}$ & $\mathrm{O}$ & $\mathrm{O}$ & $\mathrm{O}$ & $\mathrm{O}$ & $\mathrm{O}$ & $\mathrm{O}$ \\
\hline $\mathrm{O}$ & $\mathrm{O}$ & $\mathrm{O}$ & $\mathrm{O}$ & $\mathrm{O}$ & $\mathrm{O}$ & $\mathrm{O}$ & $\mathrm{O}$ & $\mathrm{O}$ & $\mathrm{O}$ & $\mathrm{O}$ & $\mathrm{O}$ \\
\hline $\mathrm{O}$ & $\mathrm{O}$ & $\mathrm{O}$ & $\mathrm{O}$ & $\mathrm{O}$ & $\mathrm{O}$ & $\mathrm{O}$ & $\mathrm{O}$ & $\mathrm{O}$ & $\mathrm{O}$ & $\mathrm{O}$ & $\mathrm{O}$ \\
\hline $\mathrm{O}$ & $\mathrm{O}$ & $\mathrm{O}$ & $\mathrm{O}$ & $\mathrm{O}$ & $\mathrm{O}$ & $\mathrm{O}$ & $\mathrm{O}$ & $\mathrm{O}$ & $\mathrm{O}$ & $\mathrm{O}$ & $\mathrm{O}$ \\
\hline $\mathrm{O}$ & $\mathrm{O}$ & $\mathrm{O}$ & $\mathrm{O}$ & $\mathrm{O}$ & $\mathrm{O}$ & $\mathrm{O}$ & $\mathrm{O}$ & $\mathrm{O}$ & $\mathrm{O}$ & $\mathrm{O}$ & $\mathrm{O}$ \\
\hline $\mathrm{O} \mathbf{C}-3$ & O C-2 & O C-3 & O C-1 & O C-3 & O $\mathbf{C - 3}$ & O C-3 & O C-3 & O C-3 & O C-1 & O C-3 & O C-1 \\
\hline O 163 & $\mathrm{O} 45$ & O 163 & O 170 & O 25 & O 170 & O 123 & O 26 & O 70 & O 170 & O 166 & O 123 \\
\hline
\end{tabular}

Figura 8 - Instalação do experimento para avaliação de plantas $V_{5}$ quanto a incidência da doença fusariose e aos caracteres de produção das linhagens selecionadas. Plantio em março de 1994: $\mathbf{x}$ - bordadura e $\mathrm{O}$ - plantas $\mathrm{V}_{5}$. 


\subsubsection{Avaliação Agronômica em plantas $\mathrm{V}_{6}$}

Uma outra área foi instalada com mudas $V_{6}$ provenientes das plantas $V_{5}$ mais vigorosas das linhagens selecionadas, mas sem identificação, cujas plantas também foram avaliadas quanto aos mesmos caracteres de produção (Figura 9).

O plantio foi realizado em 1998 em área da Associação Fomento agrícola de Tomé-Açu (ASFATA), ToméAçu, Pará, num total de 220 plantas. Das plantas $V_{6}$, cultivadas na ASFATA, foram coletadas de 5 a 10 espigas e registrados os mesmos caracteres relativos às espigas, produção das plantas individuais e peso úmido e seco de 100 frutos, além da produção total de pimenta verde e de pimenta preta visando determinar a percentagem de rendimento após a secagem (pimenta preta).

\begin{tabular}{|c|c|c|c|c|c|c|c|c|}
\hline & $\mathrm{X}$ & $\mathrm{X}$ & $\bar{X}$ & $\mathrm{X}$ & $\mathrm{X}$ & $\mathrm{X}$ & $\mathrm{X}$ & $X$ \\
\hline 29 & $\mathrm{O}$ & $\bar{O}$ & $\mathrm{O}$ & $\mathrm{O}$ & $\mathrm{O}$ & $\mathrm{O}$ & $\mathrm{O}$ & $\bar{X}$ \\
\hline 28 & $\mathrm{O}$ & $\mathrm{O}$ & $\mathrm{O}$ & $\mathrm{O}$ & $\mathrm{O}$ & $\mathrm{O}$ & $\mathrm{O}$ & $X$ \\
\hline 27 & $\mathrm{O}$ & $\mathrm{O}$ & $\mathrm{O}$ & $\mathrm{O}$ & $\mathrm{O}$ & $\mathrm{O}$ & $\mathrm{O}$ & $X$ \\
\hline 26 & $\mathrm{O}$ & $\mathrm{O}$ & $\mathrm{O}$ & $\mathrm{O}$ & $\mathrm{O}$ & $\mathrm{O}$ & $\mathrm{O}$ & $X$ \\
\hline 25 & $\mathrm{O}$ & $\mathrm{O}$ & $\mathrm{O}$ & $\mathrm{O}$ & $\mathrm{O}$ & $\mathrm{O}$ & $\mathrm{O}$ & X \\
\hline 24 & $\mathrm{O}$ & $\mathrm{O}$ & $\mathrm{O}$ & $\mathrm{O}$ & $\mathrm{O}$ & $\mathrm{O}$ & $\mathrm{O}$ & $X$ \\
\hline 23 & $\mathrm{O}$ & $\mathrm{O}$ & $\mathrm{O}$ & $\mathrm{O}$ & $\mathrm{O}$ & $\mathrm{O}$ & $\mathrm{O}$ & $X$ \\
\hline 22 & $\mathrm{O}$ & $\mathrm{O}$ & $\mathrm{O}$ & $\mathrm{O}$ & $\mathrm{O}$ & $\mathrm{O}$ & $\mathrm{O}$ & $X$ \\
\hline 21 & $\mathrm{O}$ & $\mathrm{O}$ & $\mathrm{O}$ & $\mathrm{O}$ & $\mathrm{O}$ & $\mathrm{O}$ & $\mathrm{O}$ & $X$ \\
\hline 20 & $\mathrm{O}$ & $\mathrm{O}$ & $\mathrm{O}$ & $\mathrm{O}$ & $\mathrm{O}$ & $\mathrm{O}$ & $\mathrm{O}$ & $X$ \\
\hline 19 & $\mathrm{O}$ & $\mathrm{O}$ & $\mathrm{O}$ & $\mathrm{O}$ & $\mathrm{O}$ & $\mathrm{O}$ & $\mathrm{O}$ & X \\
\hline 18 & $\mathrm{O}$ & $\mathrm{O}$ & $\mathrm{O}$ & $\mathrm{O}$ & $\mathrm{O}$ & $\mathrm{O}$ & $\mathrm{O}$ & $X$ \\
\hline 17 & $\mathrm{O}$ & $\mathrm{O}$ & $\mathrm{O}$ & $\mathrm{O}$ & $\mathrm{O}$ & $\mathrm{O}$ & $\mathrm{O}$ & $X$ \\
\hline 16 & $\mathrm{O}$ & $\mathrm{O}$ & $\mathrm{O}$ & $\mathrm{O}$ & $\mathrm{O}$ & $\mathrm{O}$ & $\mathrm{O}$ & $X$ \\
\hline 15 & $\mathrm{O}$ & $\mathrm{O}$ & $\mathrm{O}$ & $\mathrm{O}$ & $\mathrm{O}$ & $\mathrm{O}$ & $\mathrm{O}$ & $X$ \\
\hline 14 & $\mathrm{O}$ & $\mathrm{O}$ & $\mathrm{O}$ & $\mathrm{O}$ & $\mathrm{O}$ & $\mathrm{O}$ & $\mathrm{O}$ & $X$ \\
\hline 13 & $\mathrm{O}$ & $\mathrm{O}$ & $\mathrm{O}$ & $\mathrm{O}$ & $\mathrm{O}$ & $\mathrm{O}$ & $\mathrm{O}$ & $X$ \\
\hline 12 & $\mathrm{O}$ & $\mathrm{O}$ & $\mathrm{O}$ & $\mathrm{O}$ & $\mathrm{O}$ & $\mathrm{O}$ & $X$ & $X$ \\
\hline 11 & $\mathrm{O}$ & $\mathrm{O}$ & $\mathrm{O}$ & $\mathrm{O}$ & $\mathrm{O}$ & $\mathrm{O}$ & $X$ & $X$ \\
\hline 10 & $\mathrm{O}$ & $\mathrm{O}$ & $\mathrm{O}$ & $\mathrm{O}$ & $\mathrm{O}$ & $\mathrm{O}$ & $X$ & $X$ \\
\hline 9 & $\mathrm{O}$ & $\mathrm{O}$ & $\mathrm{O}$ & $\mathrm{O}$ & $\mathrm{O}$ & $\mathrm{O}$ & X & $X$ \\
\hline 8 & $\mathrm{O}$ & $\mathrm{O}$ & $\mathrm{O}$ & $\mathrm{O}$ & $\mathrm{O}$ & $\mathrm{O}$ & $X$ & $X$ \\
\hline 7 & $\mathrm{O}$ & $\mathrm{O}$ & $\mathrm{O}$ & $\mathrm{O}$ & $\mathrm{O}$ & $\mathrm{O}$ & $X$ & $X$ \\
\hline 6 & $\mathrm{O}$ & $\mathrm{O}$ & $\mathrm{O}$ & $\mathrm{O}$ & $\mathrm{O}$ & $\mathrm{O}$ & $X$ & $X$ \\
\hline 5 & $\mathrm{O}$ & $\mathrm{O}$ & $\mathrm{O}$ & $\mathrm{O}$ & $\mathrm{O}$ & $\mathrm{O}$ & $X$ & $X$ \\
\hline 4 & $\mathrm{O}$ & $\mathrm{O}$ & $\mathrm{O}$ & $\mathrm{O}$ & $\mathrm{O}$ & $\mathrm{O}$ & $X$ & $X$ \\
\hline 3 & $\mathrm{O}$ & $\mathrm{O}$ & $\mathrm{O}$ & $\mathrm{O}$ & $\mathrm{O}$ & $\mathrm{O}$ & $X$ & $X$ \\
\hline 2 & $\mathrm{O}$ & $\mathrm{O}$ & $\mathrm{O}$ & $\mathrm{O}$ & $\mathrm{O}$ & $\mathrm{O}$ & $X$ & $X$ \\
\hline 1 & $\mathrm{O}$ & $\mathrm{O}$ & $\mathrm{O}$ & $\mathrm{O}$ & $\mathrm{O}$ & $\mathrm{O}$ & $X$ & $X$ \\
\hline
\end{tabular}

Figura 9 - Área com plantas $\mathrm{V}_{6}$, plantio em 1998: $\mathrm{O}$ - plantas $\mathrm{V}_{6}$; $\mathrm{X}$ - bordadura. 


\section{RESULTADOS E DISCUSSÃO}

O trabalho permitiu o desenvolvimento de tecnologias in vitro de micropropagação, indução de calos, mutagênese e seleção in vitro, além do estabelecimento de concentração adequada de esporos do fungo Fusarium solani $f$. sp. piperis para seleção artificial, e a avaliação agronômica de plantas selecionadas para tolerância e/ou resistência à doença fusariose, originadas a partir de estacas submetidas àirradiação gama visando o melhoramento genético da cultura.

\subsection{Aplicação das técnicas in vitro}

Nesta etapa, desenvolveu-se todo o processo de micropropagação, desde a obtenção de fontes doadoras de explantes, assepsia, proliferação de novas gemas, enraizamento, aclimatação e formação de mudas. Ademais, indução de calos foi obtida a partir de diferentes explantes.

\subsubsection{Produção de plantas doadoras de explantes}

A obtenção de fontes doadoras de explantes foi fundamental para iniciar o processo de aplicação das técnicas in vitro. Tais fontes se constituíram de plantas a partir de estacas, sementes e embriões zigóticos.

\subsubsection{A partir de estacas}

A formação de mudas a partir das estacas da cultivar Cingapura foi prejudicada, principalmente pelas condições climáticas da região de Piracicaba, São Paulo. As estacas enraizaram e emitiram brotações como demonstrado por Albuquerque \& Condurú (1971) para formação de mudas, sendo que algumas mudas desenvolveram-se normalmente, as quais serviram como fontes de gemas apicais e 
axilares para estabelecer o processo de assepsia e micropropagação visando a clonagem de plantas. Ressalte-se que plantas floresceram e produziram sementes em casa-de-vegetação (Figura 10a e 10b).

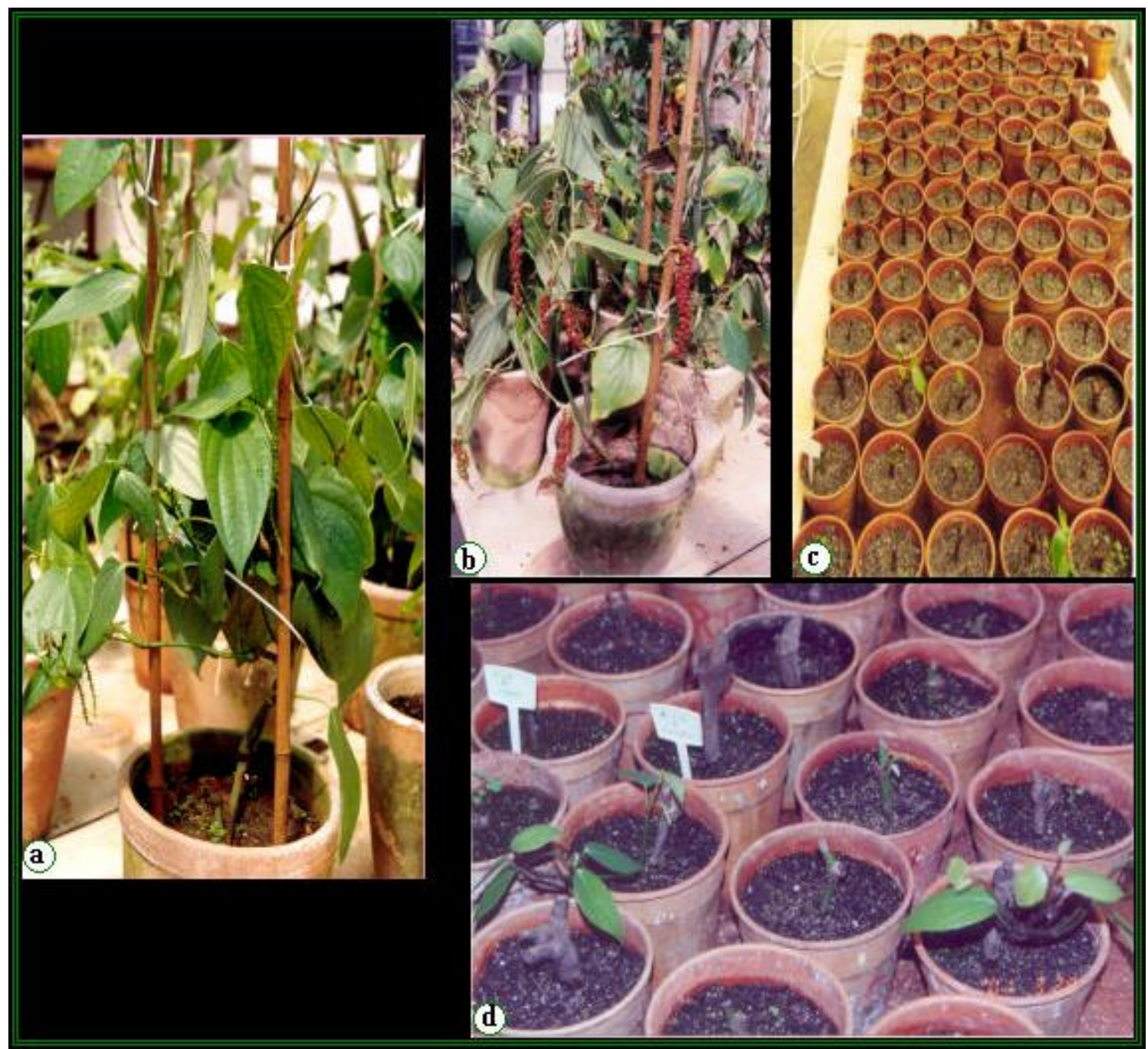

Figura 10 - Desenvolvimento de plantas de pimenta-do-reino doadoras de explantes. a-b) A partir de estacas de plantas originadas de estacas não irradiadas c-d) A partir de estacas de plantas originadas de estacas irradiadas (plantas $V_{5}$ )

As estacas de dois a três nós, obtidas de plantas $V_{5}$ com oito anos de idade, enraizaram em todas as concentrações utilizadas de NAA (0 a $100 \mathrm{mg} \cdot \mathrm{L}^{-1}$ ), e algumas emitiram brotações, mas não continuaram a desenvolver (Figura 10c e 10d). Isto se deveu ao fato de que as estacas eram lenhosas, portanto com pouca reserva nutritiva, e as condições climáticas por ocasião da emissão das brotações terem sido adversas para o desenvolvimento, ou seja, temperatura baixa (menor que $23^{\circ} \mathrm{C}$ ) e umidade baixa 
(menor que 80\%), contrastante com as condições favoráveis de cultivo: temperatura entre 23 a $28^{\circ} \mathrm{C}$ e umidade relativa do ar acima de $80 \%$, e as estacas provenientes de plantas com dois a três anos (Albuquerque et al., 1989).

\subsubsection{A partir de sementes da cultivar Cingapura}

Para a produção de plântulas in vitro, as sementes apresentaram melhores respostas quanto a conversão em plântulas em meio de cultura com a metade da concentração de sais de $\mathrm{MS}$ e $0,17 \mathrm{~g} \cdot \mathrm{L}^{-1}$ de $\mathrm{NaH}_{2} \mathrm{PO}_{4}$, ou, com concentração completa dos sais, $0,17 \mathrm{~g} \cdot \mathrm{L}^{-1}$ de $\mathrm{NaH}_{2} \mathrm{PO}_{4}$, adição de carvão ativado $(0,2 \%)$ e suplementação com NAA e BAP à concentração de $0,5 \mathrm{mg} \cdot \mathrm{L}^{-1}$, de cada (Figura 12a). Em contraste, quando não se adicionou carvão ativado no meio de cultura que continha $\mathrm{NaH}_{2} \mathrm{PO}_{4} \mathrm{e}$ os reguladores de crescimento (NAA e BAP), a indução de calos foi a principal resposta; $100 \%$ e 93,94\% nos tratamentos com completa e metade da concentração dos sais de MS, respectivamente. Este fato poderá estar relacionado à ação dos reguladores de crescimento em balanço semelhante de auxina e citocinina que são favoráveis à indução de calos, enquanto em associação com carvão ativado há uma ação mais favorável ao desenvolvimento de plântulas normais, principalmente com concentração total dos sais de MS, $71,43 \%$ de plântulas (Tabela 6 e Figura 11).

Tabela 6. Respostas in vitro de sementes de pimenta-do-reino a diferentes composições de meio de cultura (69 dias após a inoculação).

\begin{tabular}{|c|c|c|c|c|c|c|c|c|}
\hline \multirow[t]{2}{*}{ Resposta } & \multicolumn{8}{|c|}{ Tratamentos $^{1}$} \\
\hline & 1 & 2 & 3 & 4 & 5 & 6 & 7 & 8 \\
\hline $\mathrm{PN}^{2}$ & 16 & 19 & 25 & 0 & 21 & 0 & 20 & 24 \\
\hline$(\%)$ & $(45,71)$ & $(55,88)$ & $(71,43)$ & $(0,0)$ & $(65,63)$ & $(0,0)$ & $(57,14)$ & $(72,73)$ \\
\hline $\mathrm{PA}^{3}$ & & & & & & & & \\
\hline & $(54,29)$ & $(44,12)$ & $(28,57)$ & $(0,0)$ & $(34,37)$ & $(6,06)$ & $(42,86)$ & $(27,27)$ \\
\hline $\begin{array}{c}\text { Calos }^{4} \\
(\%)\end{array}$ & $\begin{array}{c}0 \\
(0,0)\end{array}$ & $\begin{array}{c}0 \\
(0,0)\end{array}$ & $\begin{array}{c}0 \\
(0,0)\end{array}$ & $\begin{array}{c}28 \\
(100,0)\end{array}$ & $\begin{array}{c}0 \\
(0,0)\end{array}$ & $\begin{array}{c}31 \\
(93,94)\end{array}$ & $\begin{array}{c}0 \\
(0,0)\end{array}$ & $\begin{array}{c}0 \\
(0,0)\end{array}$ \\
\hline \multicolumn{9}{|c|}{ 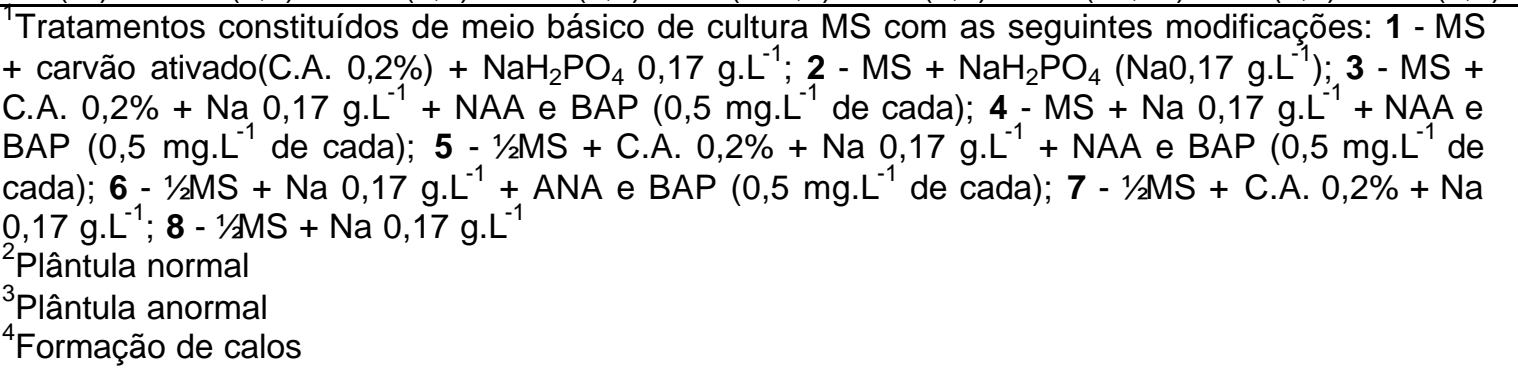 } \\
\hline
\end{tabular}




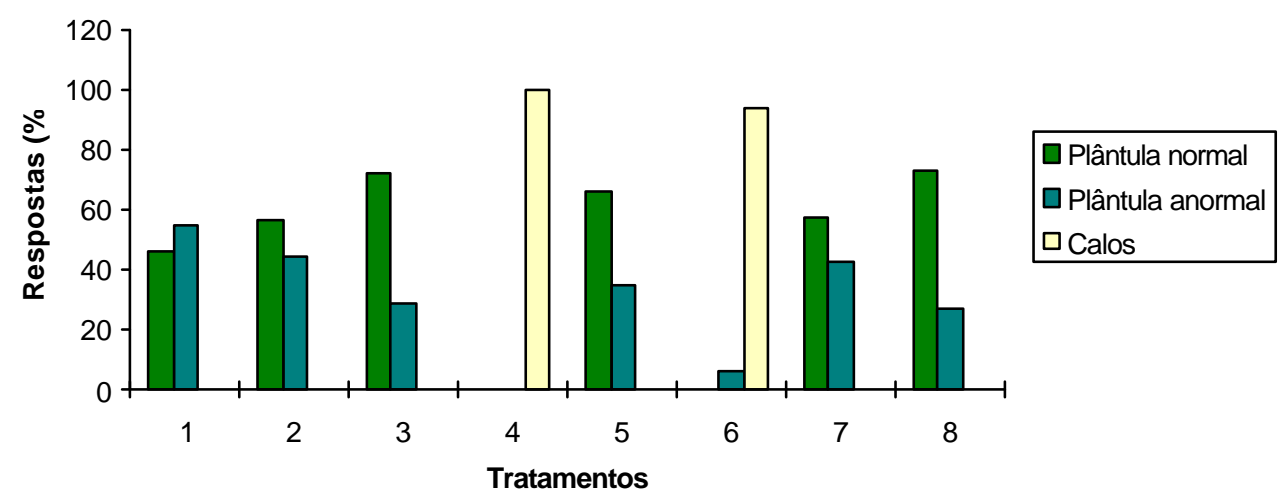

Figura 11 - Respostas in vitro de sementes a diferentes modificações do meio de cultura MS (69 dias após a inoculação).

Considerando todos os tratamentos que permitiram o desenvolvimento de plântula, o teste qui-quadrado revelou não significância para as diferenças entre o número de plântulas formadas entre si (Tabela 7). Entretanto, ao comparar a adição ou não $\mathrm{NaH}_{2} \mathrm{PO}_{4}$ nos meios de cultura, ficou evidente que este teve um papel fundamental na germinação e conversão do embrião em plântula normal, pois a diferença foi significativa acima do nível de $0,1 \%$ de probabilidade (Tabela 8). Por outro lado, a adição ou não de carvão ativado nos diferentes meios de cultura não teve influência significativa na formação de plântulas (Tabela 9), e a comparação entre a adição de carvão ativado ou adição de $\mathrm{NaH}_{2} \mathrm{PO}_{4}$ confirmou-se a importância de $\mathrm{NaH}_{2} \mathrm{PO}_{4}$, tendo diferença significativa acima do nível de $1,0 \%$ de probabilidade (Tabela 10). 
Tabela 7. Teste qui-quadrado para comparação dos principais tratamentos no desenvolvimento de plântula a partir de sementes da cultivar Cingapura.

\begin{tabular}{llccc}
\hline Tratamento & Plântula normal & Plântula anormal & Total \\
\hline 1 & $\mathrm{MS}+\mathrm{C} . \mathrm{A} .+\mathrm{Na} \mathrm{H}_{2} \mathrm{PO}_{4}$ & 16 & 19 & 35 \\
2 & $\mathrm{MS}+\mathrm{Na} \mathrm{H} \mathrm{HO}_{4}$ & 19 & 15 & 34 \\
3 & $\mathrm{MS}+\mathrm{C} . \mathrm{A} .+\mathrm{Na} \mathrm{H}_{2} \mathrm{PO}_{4}+(\mathrm{BAP}+\mathrm{NAA})$ & 25 & 10 & 35 \\
5 & $1 / \mathrm{MS}+\mathrm{C} . \mathrm{A}+\mathrm{NaH}_{2} \mathrm{PO}_{4}+(\mathrm{BAP}+\mathrm{NAA})$ & 21 & 12 & 33 \\
7 & $1 / \mathrm{MS}+\mathrm{C} . \mathrm{A} .+\mathrm{Na} \mathrm{H}_{2} \mathrm{PO}_{4}$ & 20 & 15 & 35 \\
8 & $1 / \mathrm{MS}+\mathrm{Na} \mathrm{H} \mathrm{PO}_{4}$ & 24 & 9 & 33 \\
\multirow{2}{*}{ Total } & 125 & \multicolumn{2}{c}{80} \\
\end{tabular}

Tratamentos constituídos de meio básico de cultura MS. MS - sais completo de MS; $1 / 2 \mathrm{MS}-$ metade da concentração de sais $\mathrm{MS} ; \mathrm{Na}-\mathrm{NaH}_{2} \mathrm{PO}_{4}$ a $0,17 \mathrm{~g} \cdot \mathrm{L}^{-1}$; C. A. - carvão ativado a $0,2 \%$; e BAP e NAA a $0,5 \mathrm{mg} \cdot \mathrm{L}^{-1}$ de cada

${ }^{\mathrm{NS}}$ Não significativo

Tabela 8. Teste qui-quadrado para comparação dos efeitos de meios de cultura com $\mathrm{NaH}_{2} \mathrm{PO}_{4}$ e sem $\mathrm{NaH}_{2} \mathrm{PO}_{4}$ no desenvolvimento de plântula a partir de sementes da cultivar Cingapura.

\begin{tabular}{lccc}
\hline Tratamento & Plântula normal & Plântula anormal & Total \\
\hline Com $\mathrm{NaH}_{2} \mathrm{PO}_{4}$ & 83 & 79 & 162 \\
Sem $\mathrm{NaH}_{2} \mathrm{PO}_{4}$ & 31 & 131 & 162 \\
Total & 114 & 210 & 324 \\
\hline
\end{tabular}

Significativo ao nível de $0,1 \%$ de probabilidade

Tabela 9. Teste qui-quadrado para comparação dos efeitos de meios de cultura com carvão ativado e sem carvão ativado no desenvolvimento de plântula a partir de sementes da cultivar Cingapura.

\begin{tabular}{lccc}
\hline Tratamento & Plântula normal & Plântula anormal & Total \\
\hline Com carvão & 65 & 97 & 162 \\
Sem carvão & 49 & 113 & 162 \\
Total & 114 & 210 & 324 \\
\hline
\end{tabular}

${ }^{\text {TNNão significativo }}$ 
Tabela 10. Teste qui-quadrado para comparação dos efeitos de meios de cultura com $\mathrm{NaH}_{2} \mathrm{PO}_{4}$ e com carvão ativado no desenvolvimento de plântula a partir de sementes da cultivar Cingapura.

\begin{tabular}{lccc}
\hline Tratamento & Plântula normal & Plântula anormal & Total \\
\hline Com $\mathrm{NaH}_{2} \mathrm{PO}_{4}$ & 41 & 40 & 81 \\
Com carvão & 23 & 58 & 81 \\
Total & 64 & 98 & 162 \\
\hline
\end{tabular}

${ }^{* *}$ Significativo ao nível de $1 \%$ de probabilidade

\subsubsection{A partir de sementes de plantas $\mathrm{V}_{5}$}

Para a produção de plântulas a partir das sementes das plantas $V_{5}$, originadas de estacas submetidas à irradiação gama, as análises estatísticas confirmaram que a adição de $0,17 \mathrm{~g} \cdot \mathrm{L}^{-1}$ de $\mathrm{NaH}_{2} \mathrm{PO}_{4}$ ao meio básico de cultura MS é fundamental para a formação de plântulas (Tabela 11). O teste Tukey Para comparação de médias indicou que a adição de carvão ativado a 0,2\% ao meio de cultura contendo $\mathrm{NaH}_{2} \mathrm{PO}_{4}$ não teve influência significativa no desenvolvimento de plântulas, mas que adicionado ao meio básico MS como único suplemento foi favorável.

Tabela 11. Análise em fatorial $2 \times 2$ e comparação de média de percentagem de plântulas in vitro provenientes de plantas $V_{5}$ obtidas em meio básico de cultura MS, com ou sem adição de $0,2 \%$ de carvão ativado (C. A.) combinado ou não com $0,17 \mathrm{~g} \cdot \mathrm{L}^{-1}$ de $\mathrm{NaH}_{2} \mathrm{PO} 4$.

\begin{tabular}{|c|c|c|c|c|c|c|}
\hline \multirow[t]{2}{*}{ F. V. } & \multirow[t]{2}{*}{ G. L. } & \multirow[t]{2}{*}{ Q. M. } & \multirow[t]{2}{*}{$\mathrm{F}$} & \multirow[t]{2}{*}{ Fator } & \multicolumn{2}{|c|}{ Média $^{1} \pm$ Desvio Padrão (\%) } \\
\hline & & & & & $\mathrm{C} / \mathrm{NaH}_{2} \mathrm{PO}_{4}$ & $\mathrm{~S} / \mathrm{em} \mathrm{NaH}{ }_{2} \mathrm{PO}_{4}$ \\
\hline C. A. & 1 & 8,82 & $3,83^{\mathrm{NS}}$ & & & \\
\hline $\begin{array}{l}\mathrm{NaH}_{2} \mathrm{PO}_{4} \\
\text { C. A.X Na }\end{array}$ & $\begin{array}{l}1 \\
1\end{array}$ & $\begin{array}{c}81,77 \\
5,12\end{array}$ & $\begin{array}{c}35,55^{\star *} \\
2,23^{\text {NS }}\end{array}$ & C/ C. A. & $37,76 \pm 1,96 \mathbf{a}$ & $14,91 \pm 16,87 \mathbf{b}$ \\
\hline Tratamento $^{1}$ & 3 & 31,91 & $13,87^{* *}$ & & & \\
\hline Resíduo & 32 & 2,30 & & S/C.A. & $34,90 \pm 1,06 \mathbf{a}$ & $4,25 \pm 4,41 \mathbf{b}$ \\
\hline
\end{tabular}

De todas as plântulas formadas, 70,58\% desenvolveram-se em meio básico de cultura com adição de $\mathrm{NaH}_{2} \mathrm{PO}_{4}$, combinado ou não com carvão ativado. Ademais, 
a linhagem que mais desenvolveu plântula em ralação ao total de plântulas obtidas foi C45 (17,65\%) e as de menores performances foram as N135 e a cultivar Cingapura $(4,90 \%)$ (Tabela 12). As plântulas formadas serviram de doadoras de explantes para a clonagem das progênies de cada linhagem (Figura 12b e 12c).

Tabela 12. Desenvolvimento de plântulas in vitro de linhagens de pantas $V_{5}$ e da cultivar Cingapura em meio básico de cultura MS com ou sem adição de carvão ativado a $0,2 \%$ combinado ou não com $0,17 \mathrm{~g} \cdot \mathrm{L}^{-1}$ de $\mathrm{NaH}_{2} \mathrm{PO}_{4}$.

\begin{tabular}{|c|c|c|c|c|c|c|c|}
\hline \multirow[t]{2}{*}{ Linhagem } & \multicolumn{2}{|c|}{$\mathrm{NaH}_{2} \mathrm{PO}_{4}(\%)^{1}$} & \multirow{2}{*}{$\begin{array}{c}\text { Subtotal } \\
(\%)\end{array}$} & \multicolumn{2}{|c|}{$\mathrm{S} / \mathrm{NaH}_{2} \mathrm{PO}_{4}(\%)^{1}$} & \multirow{2}{*}{$\begin{array}{c}\text { Subtotal } \\
(\%)\end{array}$} & \multirow{2}{*}{$\begin{array}{c}\text { Total }^{2} \\
(\%)\end{array}$} \\
\hline & C/ C.A. & S/C.A & & C/ C.A. & S/C.A & & \\
\hline C137 & $\begin{array}{c}25,0 \\
(3)\end{array}$ & $\begin{array}{c}41,66 \\
(5)\end{array}$ & $\begin{array}{c}66,67 \\
(8)\end{array}$ & $\begin{array}{c}16,67 \\
(2)\end{array}$ & $\begin{array}{c}16,67 \\
(2)\end{array}$ & $\begin{array}{c}33,33 \\
(4)\end{array}$ & $\begin{array}{c}11,76 \\
(12)\end{array}$ \\
\hline C166 & $\begin{array}{c}25,0 \\
(3)\end{array}$ & $\begin{array}{c}41,67 \\
(5)\end{array}$ & $\begin{array}{c}66,67 \\
(8)\end{array}$ & $\begin{array}{c}25,00 \\
(3)\end{array}$ & $\begin{array}{c}8,33 \\
(1)\end{array}$ & $\begin{array}{c}33,33 \\
(4)\end{array}$ & $\begin{array}{c}11,76 \\
(12)\end{array}$ \\
\hline C132 & $\begin{array}{c}41,67 \\
(5)\end{array}$ & $\begin{array}{c}50,00 \\
(6)\end{array}$ & $\begin{array}{c}91,67 \\
(11)\end{array}$ & $\begin{array}{c}8,33 \\
(1)\end{array}$ & $\begin{array}{c}0,00 \\
(0)\end{array}$ & $\begin{array}{c}8,33 \\
(1)\end{array}$ & $\begin{array}{c}11,76 \\
(12)\end{array}$ \\
\hline N27 & $\begin{array}{c}38,46 \\
(5)\end{array}$ & $\begin{array}{c}30,77 \\
(4)\end{array}$ & $\begin{array}{c}69,23 \\
(9)\end{array}$ & $\begin{array}{c}23,08 \\
(3)\end{array}$ & $\begin{array}{c}7,69 \\
(1)\end{array}$ & $\begin{array}{c}30,77 \\
(4)\end{array}$ & $\begin{array}{c}12,75 \\
(13)\end{array}$ \\
\hline N121 & $\begin{array}{c}40,00 \\
(6)\end{array}$ & $\begin{array}{c}26,67 \\
(4)\end{array}$ & $\begin{array}{c}66,67 \\
(10)\end{array}$ & $\begin{array}{c}26,67 \\
(4)\end{array}$ & $\begin{array}{c}6,66 \\
(1)\end{array}$ & $\begin{array}{c}33,33 \\
(5)\end{array}$ & $\begin{array}{c}14,71 \\
(15)\end{array}$ \\
\hline $\mathrm{C} 70$ & $\begin{array}{c}40,00 \\
(4)\end{array}$ & $\begin{array}{c}20,00 \\
(2)\end{array}$ & $\begin{array}{c}60,00 \\
(6)\end{array}$ & $\begin{array}{c}40,00 \\
(4)\end{array}$ & $\begin{array}{c}0,00 \\
(0)\end{array}$ & $\begin{array}{c}40,00 \\
(4)\end{array}$ & $\begin{array}{l}9,81 \\
(10)\end{array}$ \\
\hline CING. & $\begin{array}{c}80,00 \\
(4)\end{array}$ & $\begin{array}{c}20,00 \\
(1)\end{array}$ & $\begin{array}{c}100,0 \\
\text { (5) }\end{array}$ & $\begin{array}{c}0,00 \\
(0)\end{array}$ & $\begin{array}{c}0,00 \\
(0)\end{array}$ & $\begin{array}{c}0,00 \\
(0)\end{array}$ & $\begin{array}{c}4,90 \\
(5)\end{array}$ \\
\hline C45 & $\begin{array}{c}22,22 \\
(4)\end{array}$ & $\begin{array}{c}33,33 \\
(6)\end{array}$ & $\begin{array}{c}55,55 \\
(10)\end{array}$ & $\begin{array}{c}27,78 \\
(5)\end{array}$ & $\begin{array}{c}16,67 \\
(3)\end{array}$ & $\begin{array}{c}44,45 \\
(8)\end{array}$ & $\begin{array}{c}17,65 \\
(18)\end{array}$ \\
\hline N135 & $\begin{array}{c}40,00 \\
2\end{array}$ & $\begin{array}{c}60,00 \\
3\end{array}$ & $\begin{array}{c}100,0 \\
5\end{array}$ & $\begin{array}{c}0,00 \\
0\end{array}$ & $\begin{array}{c}0,00 \\
0\end{array}$ & $\begin{array}{c}0,00 \\
0\end{array}$ & $\begin{array}{c}4,90 \\
(5)\end{array}$ \\
\hline Total $(\%)^{2}$ & $\begin{array}{c}35,29 \\
(36)\end{array}$ & $\begin{array}{c}35,29 \\
(36)\end{array}$ & $\begin{array}{c}70,58 \\
(72)\end{array}$ & $\begin{array}{c}21,57 \\
(22)\end{array}$ & $\begin{array}{c}7,85 \\
(8)\end{array}$ & $\begin{array}{c}29,42 \\
(30)\end{array}$ & $\begin{array}{c}100,00 \\
(102)\end{array}$ \\
\hline
\end{tabular}

${ }^{\mathrm{T}}$ Percentagem relativa de plântula formada em cada tratamento ao total da linhagem a que pertence;

${ }^{2}$ Percentagem relativa de plântula formada por linhagem e por meio de cultura em relação ao total geral de plântula formada (100\%)

As sementes das plantas $V_{5}$ das diferentes linhagens apresentaram diferenças quanto a capacidade de germinação e formação de plântulas, e essas diferenças entre as linhagens foram significativas quando analisadas pelo teste quiquadrado ao nível de 5,0\% de probabilidade. As sementes das linhagens C45 e N121 foram mais viáveis para a formação de plântulas normais in vitro (Tabela 13). Há indícios da radiação gama ter afetado o DNA genômico com reflexos na divisão meiótica, o que poderia ser confirmado através de análises citogenéticas do material. 
Entretanto, a baixa viabilidade das sementes parece ser um caráter intrínseco desta cultivar Cingapura.

Ressalte-se que sementes obtidas a partir de plantas originadas de estacas crescidas em casa-de-vegetação germinaram e desenvolveram plântulas normais (Figura 12d) em meio básico de cultura MS, com adição de $\mathrm{NaH}_{2} \mathrm{PO}_{4}\left(0,17 \mathrm{~g} \cdot \mathrm{LL}^{-1}\right) \mathrm{e}$ carvão ativado $(0,2 \%)$, confirmando a eficiência do meio de cultura estabelecido para a produção de fontes doadoras de explantes. Esta tecnologia in vitro poderá ser estendida para a produção de progênies a partir de cruzamentos de cultivares da espécie Piper nigrum $L$ dentro de um programa de melhoramento genético.

Tabela 13. Teste qui-quadrado para comparação do desenvolvimento de plântula a partir de sementes das diferentes linhagens $V_{5}$ em condições in vitro.

\begin{tabular}{|c|c|c|c|c|c|}
\hline Linhagem $V_{5}$ & Plântula normal & $(\%)$ & Plântula anormal & $(\%)$ & Total \\
\hline C137 & 12 & 33,33 & 24 & 66,67 & 36 \\
\hline C166 & 12 & 33,33 & 24 & 66,67 & 36 \\
\hline C132 & 12 & 33,33 & 24 & 66,67 & 36 \\
\hline N27 & 13 & 36,11 & 23 & 63,89 & 36 \\
\hline N121 & 15 & 41,67 & 21 & 58,33 & 36 \\
\hline C70 & 10 & 27,78 & 26 & 72,22 & 36 \\
\hline CING. & 5 & 13,89 & 31 & 86,11 & 36 \\
\hline C45 & 18 & 50,00 & 18 & 50,00 & 36 \\
\hline N135 & 5 & 13,89 & 31 & 86,11 & 36 \\
\hline Total & 102 & & $\begin{array}{r}222 \\
8,30^{*} ; \text { g.I }=8\end{array}$ & & 324 \\
\hline
\end{tabular}

*Significativo ao nível de 5\% de probabilidade 


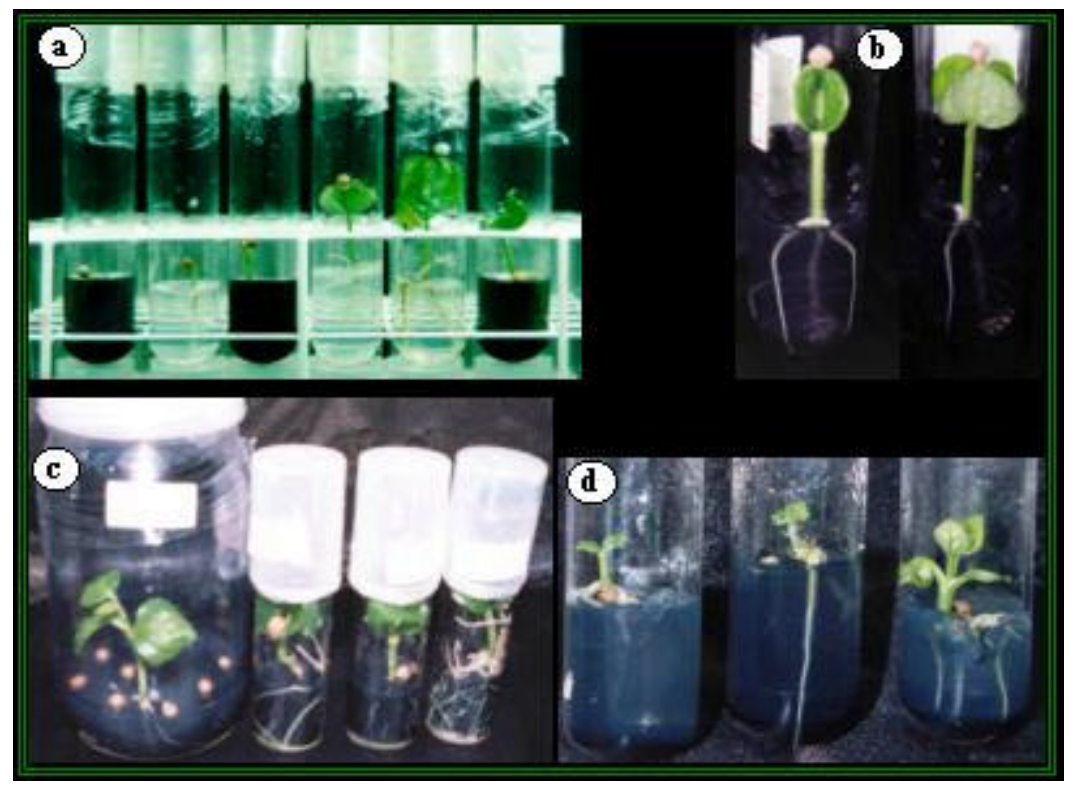

Figura 12 - Produção de plântulas doadoras de explantes a partir de sementes.

a) Da Cultivar Cingapura (I experimento)

b) De plantas $\mathrm{V}_{5}$ em meio de cultura MS com carvão ativado, $\mathrm{NaH}_{2} \mathrm{PO} 4$ e BAP e NAA

c) De plantas $\mathrm{V}_{5}$ em meio de cultura MS com carvão ativado e $\mathrm{NaH}_{2} \mathrm{PO} 4$

d) De sementes de plantas originadas de estacas em casa-de-vegetação

\subsubsection{A partir de embriões zigóticos}

Neste experimento, foi observado o desenvolvimento de plântulas a partir de 15 dias após o cultivo dos embriões in vitro. A conversão dos embriões zigóticos em plântulas foi mais favorável em meio de cultura com a metade da concentração dos sais de MS (tratamentos 1, 3, 5 e 7), quando comparado com a concentração completa de sais $(2,4,6$ e 8) (Tabela 14). Outrossim, a utilização de carvão ativado $(0,2 \%)$ melhora a eficiência de conversão a plântulas, tanto na metade quanto na completa concentração de sais de MS na presença $\mathrm{NaH}_{2} \mathrm{PO}_{4}$, mas não na presença de BAP e NAA. No meio de cultura com a concentração completa de sais, a presença BAP e NAA tem ação inibidora e corrobora com o fato de que os embriões uma vez no estádio cotiledonar sintetizam os hormônios necessários para seu desenvolvimento, pois a adição de BAP e NAA $\left(0,5 \mathrm{mg} \cdot \mathrm{L}^{-1}\right)$ não teve influência na formação de plântulas, mas reduziu a ocorrência de plântulas anormais.

Em todos os tratamentos, houve conversão de embriões em plântulas (Figura 13), com destaque em meios de cultura com metade da concentração de MS 
(tratamentos 5 e 7), na tabela 9, nos quais havia a adição de carvão ativado. O carvão ativado teve um papel importante, devido à ação de agregar compostos tóxicos, tais como compostos fenólicos, e reduzir a disponibilidade æ̀ células dos constituintes do meio de cultura. A redução da concentração de sais foi observada como favorável à conversão de embriões somáticos em plântulas em pimenta-do-reino por Joseph et al. (1996), ao utilizarem a metade das concentrações de sais do meio básico de cultura $\mathrm{SH}$ e redução de 3,0 para $1,5 \%$ a concentração de sacarose.

Tabela 14. Percentagem de plântulas de pimenta-do-reino desenvolvidas in vitro a partir de embriões zigóticos da cultivar Cingapura em meio básico de cultura MS com metade ou completa concentração dos sais e adição de diferentes suplementos.

\begin{tabular}{|c|c|c|c|c|}
\hline \multirow[t]{2}{*}{ Tratamento $^{1}$} & \multicolumn{3}{|c|}{ Resposta (\%) } & \multirow[t]{2}{*}{ Total } \\
\hline & Plânt. normal & Plânt. anormal & S/ diferenciação & \\
\hline $11 / 1 / 1 S$ & $7(36,84)$ & $3(15,79)$ & $9(47,37)$ & 19 \\
\hline 2 MS & $7(26,74)$ & $4(21,05)$ & $8(52,21)$ & 19 \\
\hline $3 \quad 1 / \mathrm{NS}+\mathrm{NaH}_{2} \mathrm{PO}_{4}$ & $5(33,33)$ & $3(20,00)$ & $7(46,67)$ & 15 \\
\hline $4 \quad \mathrm{MS}+\mathrm{Na} \mathrm{H} \mathrm{PO}_{4}$ & $2(11,11)$ & $2(11,11)$ & $14(77,78)$ & 18 \\
\hline $5 \quad 1 \mathrm{MS}+\mathrm{NaH}_{2} \mathrm{PO}_{4}+\mathrm{C} . \mathrm{A}$. & $14(82,35)$ & $1(5,88)$ & $2(11,77)$ & 17 \\
\hline $6 \mathrm{MS}+\mathrm{NaH}_{2} \mathrm{PO}_{4}+\mathrm{C} . \mathrm{A}$. & $11(64,70)$ & $3(17,65)$ & $3(17,65)$ & 17 \\
\hline $7 \quad 1 / \mathrm{AS}+\mathrm{NaH}_{2} \mathrm{PO}_{4}+\mathrm{C} \cdot \mathrm{A} .+(\mathrm{BAP}+\mathrm{NAA})$ & $15(78,95)$ & $1(5,26)$ & $3(15,79)$ & 19 \\
\hline $8 \quad \mathrm{MS}+\mathrm{NaH}_{2} \mathrm{PO}_{4}+\mathrm{C} \cdot \mathrm{A} \cdot+(\mathrm{BAP}+\mathrm{NAA})$ & $7(38,89)$ & $2(11,11)$ & $9(50,00)$ & 18 \\
\hline Total & $68(47,89 \%)$ & $19(13,38 \%)$ & $55(38,73 \%)$ & 142 \\
\hline \multicolumn{5}{|c|}{$\begin{array}{l}\text { Tratamentos constituídos de meio básico de cultura MS e adição de diferentes suplementos: } 1 / 22 \\
\text { MS - metade da concentração dos sais de } \mathrm{MS} \text {; MS - concentração completa dos sais de } \mathrm{MS} \text {; } \\
\mathrm{NaH}_{2} \mathrm{PO}_{4}-0,17 \mathrm{~g} \cdot \mathrm{L}^{-1} ; \text { C.A. - carvão ativado a } 0,2 \% \text {; (BAP+NAA) - 0,5 mg. } \mathrm{L}^{-1} \text { de cada }\end{array}$} \\
\hline \multicolumn{5}{|c|}{$\begin{array}{l}\text { O teste qui-quadrado mostrou as diferenças significativas de conversão a } \\
\text { plântulas dos embriões entre os tratamentos ao nível de } 0,1 \% \text { de probabilidade, } \\
\text { principalmente devido aos tratamentos que continham } \mathrm{NaH}_{2} \mathrm{PO}_{4} \text { e carvão ativado ou } \\
\text { ainda estes, em metade da concentração de sais de } \mathrm{MS} \text { combinados com BAP e NAA } \\
\text { àconcentração de } 0,5 \mathrm{mg} \cdot \mathrm{L}^{-1} \text { de cada (Tabela } 15 \text { ). }\end{array}$} \\
\hline
\end{tabular}


Tabela 15. Teste qui-quadrado para comparação dos principais tratamentos na diferenciação dos embriões cultivados em diferentes meios de cultura.

\begin{tabular}{|c|c|c|c|}
\hline \multirow[t]{2}{*}{ Tratamento } & \multicolumn{2}{|c|}{ Embriões } & \multirow[t]{2}{*}{ Total } \\
\hline & Com diferenciação & Sem diferenciação & \\
\hline $11 /$ MS & 10 & 9 & 19 \\
\hline $2 \mathrm{MS}$ & 11 & 8 & 19 \\
\hline 3 1/ $/ \mathrm{NS}+\mathrm{Na}$ & 8 & 7 & 15 \\
\hline $4 \mathrm{MS}+\mathrm{Na}$ & 4 & 14 & 18 \\
\hline 5 S $+\mathrm{Na}+\mathrm{C} . \mathrm{A}$. & 15 & 2 & 17 \\
\hline $6 \mathrm{MS}+\mathrm{Na}+\mathrm{C} . \mathrm{A}$. & 14 & 3 & 17 \\
\hline $7 \mathrm{MS}+\mathrm{Na}+\mathrm{C} \cdot \mathrm{A}+(\mathrm{B}+\mathrm{NAA})$ & 16 & 3 & 19 \\
\hline $8 \mathrm{MS}+\mathrm{Na}+\mathrm{C} \cdot \mathrm{A} \cdot+(\mathrm{B}+\mathrm{NAA})^{\prime}$ & 9 & 9 & 18 \\
\hline Total & $\begin{array}{c}87 \\
\chi^{2}=2622^{* *} \cdot g l=7\end{array}$ & 55 & 142 \\
\hline
\end{tabular}

Significativo ao nível de $1 \%$ de probabilidade

Outrossim, o teste qui-quadrado confirmou que os meios de cultura com metade da concentração de sais de MS foram mais favoráveis na conversão dos embriões zigóticos em plântulas em nível de $5,0 \%$ de probabilidade (Tabela 16).

Tabela 16. Teste qui-quadrado para comparação dos efeitos de meios de cultura com completa (MS) ou metade (1/1/MS) da concentração de sais de MS na diferenciação de embriões zigóticos.

\begin{tabular}{lccc}
\hline Tratamento & & \multirow{2}{*}{ Total } \\
\cline { 2 - 3 } & Com diferenciação & Sem diferenciação & \\
\hline 1/aMS & 49 & 21 & 70 \\
MS & 38 & 34 & 72 \\
Total & 87 & 55 & 142 \\
& & $\chi^{2}=4,43^{*} ;$ g.l. $=1$ & \\
\hline
\end{tabular}

*Significativo ao nível de 5\% de probabilidade 


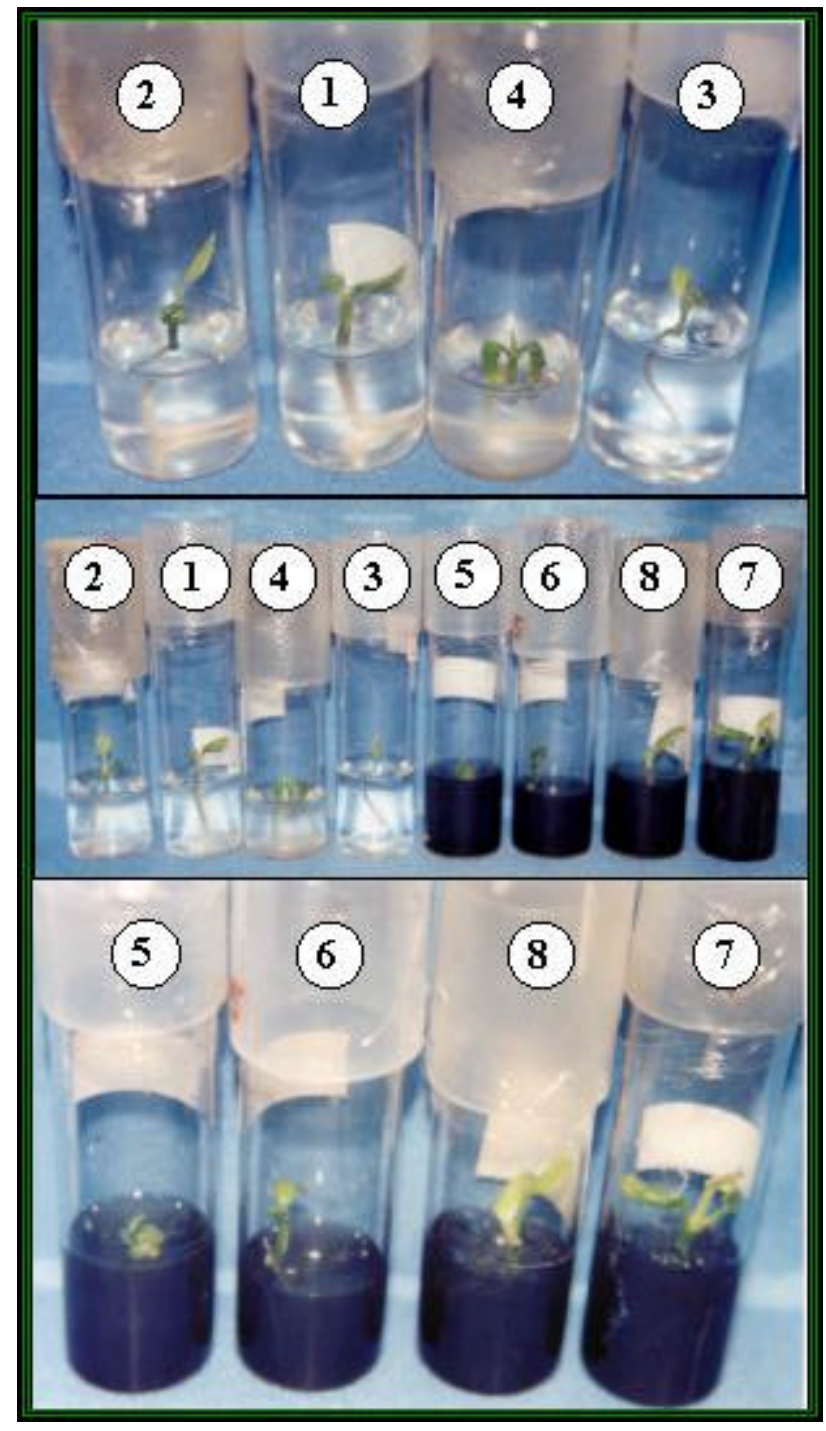

Figura 13 - Conversão de embriões zigóticos em plântulas em diferentes meios de cultura (tratamentos 1 a 8, Tabela 9).

A tecnologia de produção de plântulas in vitro será uma ferramenta muito útil dentro de um programa de melhoramento genético pois permitirá a geração de progênies de cruzamentos incompatíveis e ainda, auxiliará na definição de condições adequadas para resgate de embriões de cruzamentos interespecíficos, além de ser uma fonte doadora de explante para o processo de micropropagação. 


\subsubsection{Micropropagação}

O processo de micropropagação foi estabelecido através da utilização de explantes assépticos (gemas axilares e apicais) a partir de plântulas obtidas in vitro, em diversos experimentos para multiplicação de gemas, enraizamento, aclimatação e formação de mudas em casa-de-vegetação. Além disso, gemas provenientes de plantas propagadas via estacas foram submetidas a tratamentos de assepsia e aquelas sobreviventes passaram pelo processo de micropropagação através das condições preestabelecidas e obteve-se também, indução de calos em vários tipos de explantes.

\subsubsection{Estabelecimento e multiplicação de gemas}

As gemas fornecidas pelas plântulas in vitro após duas semanas de cultivo, em meio básico de cultura MS suplementado com 0,5 mg. $\mathrm{L}^{-1}$ de BAP e 0,2 mg. $\mathrm{L}^{-1}$ de IAA, com aspecto verde mas não diferenciadas, foram estabelecidas em cultura (Figura 14a). A proliferação de brotos ocorreu após oito semanas (Figura 14c), nos diferentes tratamentos a que foram submetidas após estabelecimento em cultura, sendo que as análises estatísticas não revelaram diferença significativa no primeiro subcultivo quanto a média de novas gemas produzidas em cada tratamento (média de 3,4 a 5,2 gemas/tratamento), quer seja com BAP a diferentes concentrações $\left(0,1\right.$ a 2,0 mg. $\left.\mathrm{L}^{-1}\right)$ combinado ou não com $0,2 \mathrm{mg} \cdot \mathrm{L}^{-1}$ de IAA.

Esse fato deveu-se ao período no qual os explantes permaneceram em fase de estabelecimento, pois mesmo tendo sido transferidos para condições de meios de cultura com balanço de fitorregulador exógeno diferente da fase inicial, o estímulo à diferenciação já tinha sido iniciado e as respostas aos novos tratamentos não influenciaram diferentemente na taxa de proliferação de novas gemas. Entretanto, no segundo subcultivo, houve diferença significativa entre as concentrações de BAP testadas, porém sem interação significativa com IAA. Neste caso, a melhor performance foi observada com a concentração de $0,5 \mathrm{mg} \cdot \mathrm{L}^{-1}$ de BAP, sendo a média de 5,6 novas gemas por explante (Tabelas 17 e 18). 
Tabela 17. Análises da variância do delineamento inteiramente casualizado em fatorial 2X4 (BAP X IAA) quanto a proliferação de gemas em dois subcultivos consecutivos, a cada oito semanas.

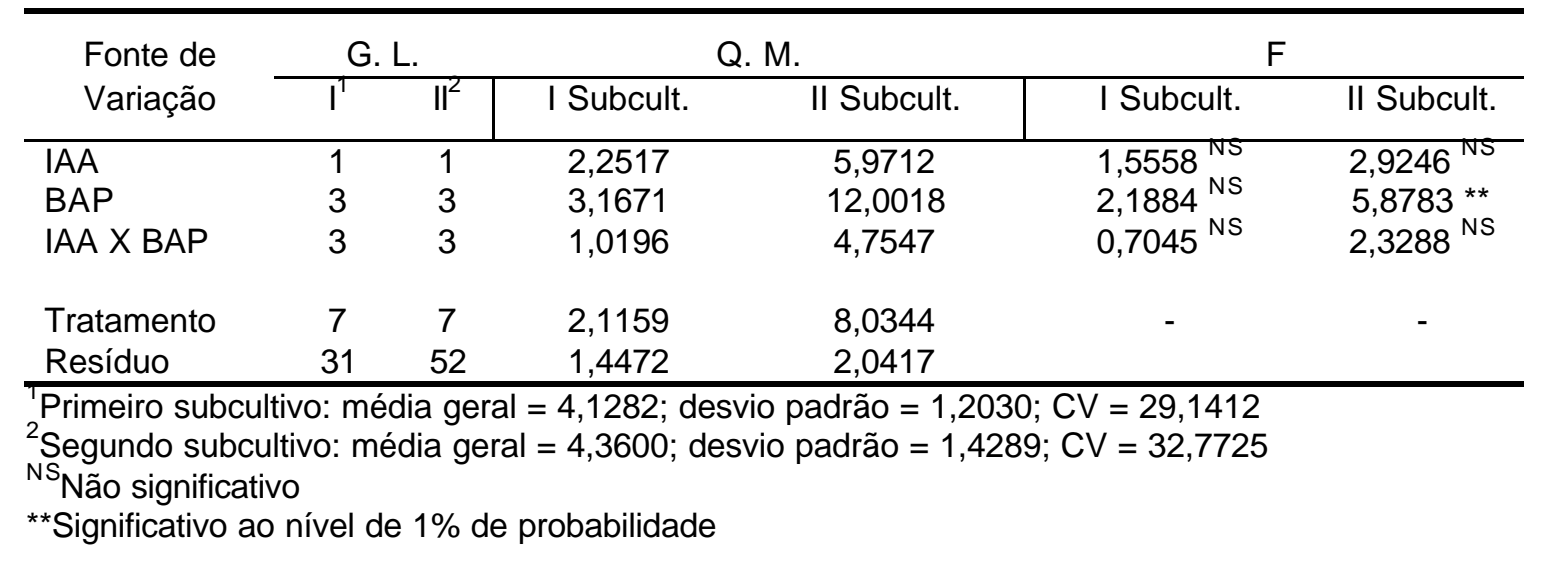

Os meios de cultura contendo BAP à concentração de 0,1 e 0,5 mg. $\mathrm{L}^{-1}$ permitiram maior quantidade de diferenciação de novas gemas, independentemente da combinação ou não com IAA, cuja comparação de médias dos tratamentos mostrou diferença significativa no segundo subcultivo (Tabela 18).

Tabela 18. Proliferação in vitro de brotos a partir de segmentos nodais e ápices caulinares de pimenta-do-reino em meio básico de cultura MS suplementado com diferentes combinações de concentrações de IAA $X$ BAP, subcultivados a cada oito semanas em dois subcultivos.

\begin{tabular}{|c|c|c|c|c|c|c|}
\hline \multirow{3}{*}{$\begin{array}{c}\text { BAP } \\
\left(\mathrm{mg} \cdot \mathrm{L}^{-1}\right)\end{array}$} & \multicolumn{3}{|c|}{ I Subcultivo } & \multicolumn{3}{|c|}{ II Subcultivo } \\
\hline & \multicolumn{2}{|c|}{ IAA $\left(m g \cdot L^{-1}\right)$} & \multirow[t]{2}{*}{ Média' } & \multicolumn{2}{|c|}{ IAA (mg..$\left.^{-1}\right)$} & \multirow[t]{2}{*}{ Média' } \\
\hline & 0,2 & 0,0 & & 0,2 & 0,0 & \\
\hline 0,1 & 5,1980 & 3,9680 & $4,5830 \mathbf{a}$ & 4,0938 & 4,3100 & $4,2019 \mathbf{a b}$ \\
\hline 0,5 & 4,8680 & 4,4000 & $4,6340 \mathbf{a}$ & 6,7700 & 4,4150 & $5,5925 \mathbf{a}$ \\
\hline 1,0 & 4,1900 & 3,3900 & $3,7900 \mathbf{a}$ & 4,0956 & 3,3333 & $3,7144 \quad$ b \\
\hline 2,0 & 3,1657 & 3,5850 & $3,3754 \mathbf{a}$ & 3,3333 & 3,5267 & $3,4300 \quad \mathbf{b}$ \\
\hline Média $^{1}$ & $4,3554 \mathrm{~A}$ & $3,8358 \mathrm{~A}$ & 4,0956 & $4,5732 \mathrm{~A}$ & $3,8963 \mathrm{~A}$ & 4,2347 \\
\hline
\end{tabular}

As respostas quanto ao efeito das concentrações de BAP, 1,5 e 3,0 mg. $\mathrm{L}^{-1}$, foram diferentes significativamente tanto pelas variâncias (Tabela 19) quanto pelas médias de novas gemas por explante no primeiro subcultivo. Média de 5,55 gemas à 
concentração de BAP 1,5 mg. $\mathrm{L}^{-1}$, comparada com média de 3,07 gemas/explante produzidas à concentração de $3,0 \mathrm{mg} \cdot \mathrm{L}^{-1}$, enquanto no segundo subcultivo, essa diferença não foi significativa, mas com melhor performance, ainda, àconcentração de BAP 1,5 mg. $\mathrm{L}^{-1}$, média de 4,28 em relação a 3,77 a $3,0 \mathrm{mg} \cdot \mathrm{L}^{-1}$ de BAP (Tabela 20). Ressalte-se que os explantes, em todos os tratamentos testados, apresentaram formação de calos na base, aspecto observado por Mathews \& Rao (1984) ao utilizarem IAA e principalmente NAA.

Tabela 19. Análise da variância de efeito de duas concentrações de BAP na proliferação de brotos de pimenta-do-reino após 8 e 4 semanas em dois subcultivos, respectivamente.

\begin{tabular}{lccccc}
\hline \multirow{2}{*}{$\begin{array}{l}\text { Fonte de } \\
\text { Variação }\end{array}$} & G. L. & \multicolumn{2}{c}{ Q. M. } & \multicolumn{2}{c}{ F } \\
\cline { 3 - 6 } Tratamento & 1 & 26,4749 & 1,1603 & $19,09^{* *}$ & $0.63^{\text {NS }}$ \\
Resíduo & 16 & 1,3865 & 1,8368 & & \\
\end{tabular}

Primeiro subcultivo por 8 semanas: média geral $=4,2872$; desvio padrão $=1,1775$; $\mathrm{CV}=27,47$

${ }^{2}$ Segundo subcultivo por 4 semanas: média geral $=4,0250$; desvio padrão $=1,3553 ; \mathrm{CV}=33,67$

NS - não significativo

** - significativo ao nível de $1 \%$ de probabilidade

Tabela 20. Média de proliferação in vitro de brotos por explantes em meio básico de cultura MS suplementado com BAP por 8 e 4 semanas em dois subcultivos, respectivamente.

\begin{tabular}{lcc}
\hline \multirow{2}{*}{$\begin{array}{l}\text { BAP } \\
\left.\text { (mg. } \text { - }^{-1}\right)\end{array}$} & \multicolumn{2}{c}{ Brotos/explante $^{1}$} \\
\cline { 2 - 3 } & I Subcultivo & "l Subcultivo \\
\hline 1,5 & $5,5000 \mathbf{a}$ & $4,2789 \mathbf{a}$ \\
3,0 & $3,0744 \mathbf{b}$ & $3,7711 \mathbf{a}$ \\
& & 4,025 \\
Média & 4.2872 & \\
Médias seguidas pela mesma letra não diferem entre si estatisticamente ao nível de $5 \%$ de \\
probabilidade
\end{tabular}

No experimento no qual se testou várias concentrações de $\operatorname{BAP}(0,5 ; 1,0 ; 2,0$; e 4,0 mg. $\left.\mathrm{L}^{-1}\right)$ em combinação com IAA $(0,0 ; 0,1 ; 0,2 ; 0,3$; e 0,5$)$ em três subcultivos consecutivos, houve diferença significativa entre os tratamentos testados (Tabela $21 \mathrm{e}$ Figura 14d). 
Tabela 21. Análise da variância quanto ao efeito da combinação de BAP $x$ IAA na proliferação de gemas de pimenta-do-reino em três subcultivos consecutivos, após 8, 6 e 6 semanas, respectivamente.

\begin{tabular}{|c|c|c|c|c|c|c|c|c|c|}
\hline \multirow[t]{2}{*}{ F. V. } & \multicolumn{3}{|c|}{ G. L. } & \multicolumn{3}{|c|}{ Q. M. } & \multicolumn{3}{|c|}{$F$} \\
\hline & 1 & $\|^{2}$ & $\mathrm{III}^{3}$ & 1 & $\|^{2}$ & $\mathrm{III}^{3}$ & $I^{1}$ & $\|^{2}$ & $\mid \mathrm{III}^{3}$ \\
\hline Trat. & 12 & 12 & 12 & 13,98 & 8,41 & 3,75 & $16,38^{\star \star}$ & $7,80^{\star *}$ & $2,69^{\star *}$ \\
\hline Res. & 65 & 117 & 104 & 0,85 & 2,41 & 1,40 & 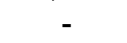 & - & - \\
\hline $\begin{array}{l}\text { Primeirc } \\
{ }^{2} \text { Segund } \\
{ }^{3} \text { Terceirc } \\
\text { NS Não } \\
{ }^{* *} \text { Nánific }\end{array}$ & $\begin{array}{l}\text { ubct } \\
\text { subc } \\
\text { ubct } \\
\text { ifica } \\
\text { vo a }\end{array}$ & $\begin{array}{l}\text { ivo po } \\
\text { tivo p } \\
\text { ivo po } \\
\text { o } \\
\text { nível }\end{array}$ & $\begin{array}{l}60 \mathrm{~d} \\
45 \mathrm{~d} \\
45 \mathrm{di}\end{array}$ & $\begin{array}{l}\text { desvio } \\
\text { desvio } \\
\text { desvio }\end{array}$ & $\begin{array}{l}\text { rão = } \\
\text { rão = } \\
\text { rão }=\end{array}$ & $\begin{array}{l}; C V \\
8 ; C V \\
; C V\end{array}$ & $\begin{array}{l}3 \% \\
11 \% \\
3 \% \\
3 \%\end{array}$ & & \\
\hline
\end{tabular}

Os destaques quanto a diferenciação de novas gemas por explante ficaram para os meios de cultura com BAPxIAA, cujas médias variaram de 4,50 a 6,0;3,40 a 4,70; e 3,83 a 5,10 gemas nos primeiro, segundo e terceiro subcultivo, respectivamente (Tabela 22 e Figura 14d).

Tabela 22. Média de proliferação in vitro de gemas por explante em meio básico de cultura MS suplementado com diferentes combinações de BAPXIAA em três subcultivos consecutivos, após 8, 6 e 6 semanas, respectivamente.

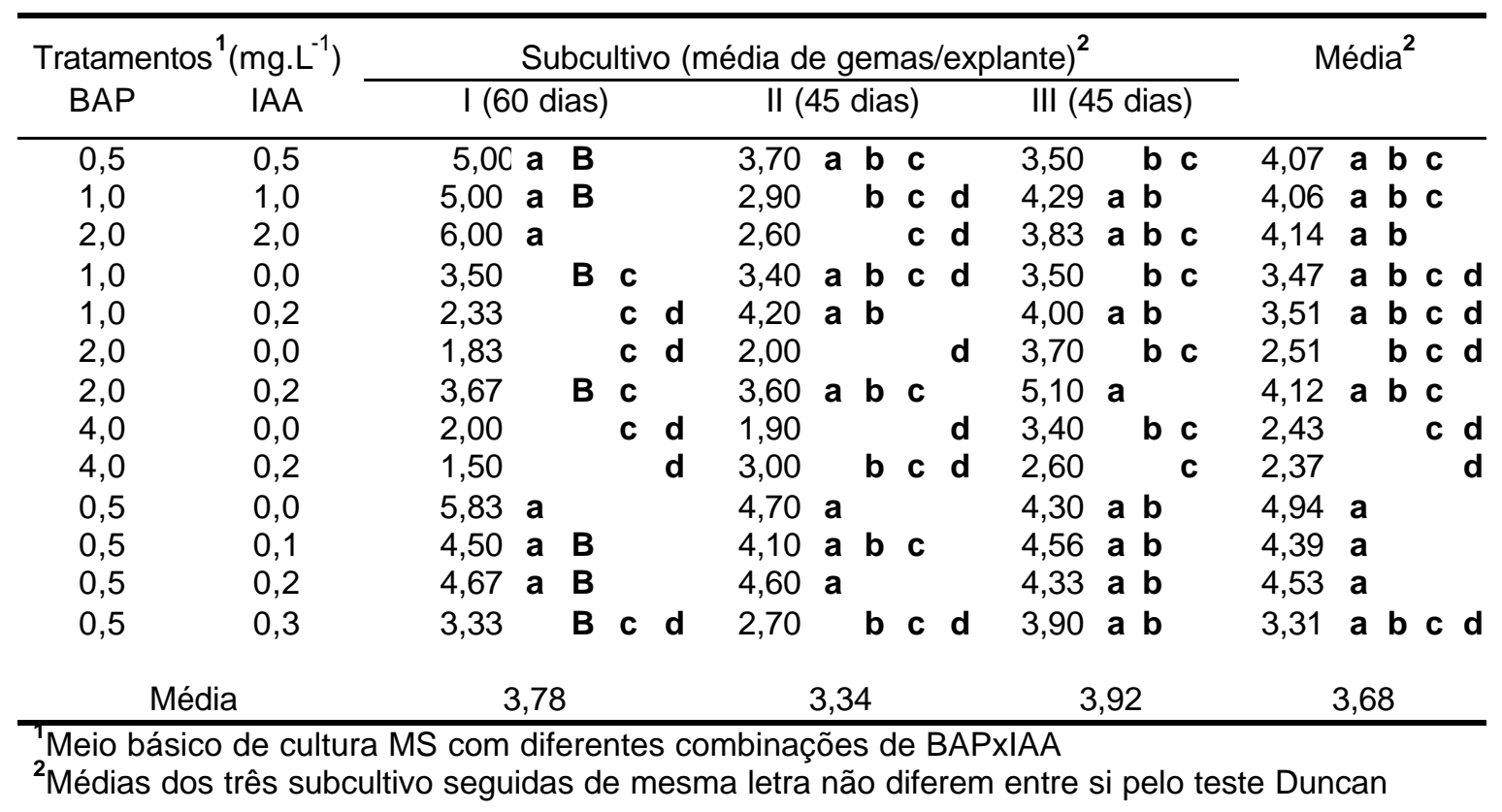


Ressalte-se que a análise conjunta dos três subcultivos confirmou diferença significativa entre os tratamentos (Tabela 23), evidenciando que a concentração de 0,5 $m g . L^{-1}$ foi a mais eficiente para a diferenciação de gemas (maior que 4,0 gemas/explante), quer seja sozinho, quer seja combinado com IAA à concentração de 0,1 e $0,2 \mathrm{mg} \cdot \mathrm{L}^{-1}$. Estes resultados foram contrastantes com aqueles obtidos por Philip et al. (1992), que observaram melhores resultados com BAP à concentração de BAP 1,5 e $3,0 \mathrm{mg} \cdot \mathrm{L}^{-1}$.

Tabela 23. Análise da variância conjunta dos três subcultivos quanto ao efeito da combinação de BAP x IAA na proliferação de gemas de pimenta-do-reino.

\begin{tabular}{|c|c|c|c|}
\hline Fonte de Variação & G. L. & Q. M. & $\mathrm{F}$ \\
\hline $\begin{array}{l}\text { Tratamentos } \\
\text { Resíduo }\end{array}$ & $\begin{array}{l}12 \\
26\end{array}$ & $\begin{array}{c}2,098 \\
0,70\end{array}$ & $2,73^{*}$ \\
\hline
\end{tabular}

No quarto experimento, no qual se avaliou o efeito de BAP $\left(0,1\right.$ e 0,5 mg. $\left.\mathrm{L}^{1}\right)$ em combinação com IAA $\left(0,0 ; 0,1 \quad 0,2\right.$ e 0,5 mg. $\left.\mathrm{L}^{-1}\right)$ com adição ou não de carvão ativado a $0,2 \%$, em dois subcultivos consecutivos, a média de gemas por explante no primeiro subcultivo variou de 1,79 a 3,48 , enquanto no segundo subcultivo houve uma maior estabilidade com variação de 2,21 a 3,49 gemas por explante (Tabela 24 e Figura 14e).

No primeiro subcultivo, a maior média (3,48 gemas por explante) foi observada em meio de cultura contendo BAP $0,1 \mathrm{mg} \cdot \mathrm{L}^{-1}$ na ausência de carvão ativado, com resposta semelhante no segundo subcultivo, mas na presença de carvão ativado (3,45 gemas por explante). No segundo subcultivo em meio de cultura contendo BAP a $0,5 \mathrm{mg} \cdot \mathrm{L}^{-1}$ e IAA $0,1 \mathrm{mg} \cdot \mathrm{L}^{-1}$, também, na presença de carvão ativado, ocorreu a maior média (3,49 gemas por explante), porém na ausência de carvão ativado foi observada a menor média (2,21 gemas por explante).

A oxidação na base dos explantes foi um fator prejudicial à proliferação de gemas, sendo um aspecto observado também por Philip et al. (1992), mas em baixa intensidade não interferiu na ação dos reguladores de crescimento. Entretanto, à medida que aumentou esta oxidação, como observado no segundo subcultivo, o uso 
de carvão ativado favoreceu a diferenciação de novas gemas, principalmente na concentração mais elevada de $\operatorname{BAP}\left(0,5 \mathrm{mg} \cdot \mathrm{L}^{-1}\right)$ em comparação com a de $0,1 \mathrm{mg} \cdot \mathrm{L}^{-1}$.

Tabela 24. Média de gemas por explante em dois subcultivos consecutivos em meio básico MS com adição ou não de carvão ativado a 0,2\%, suplementado com diferentes combinações de BAPxIAA, aos 45 dias e 60 dias.

\begin{tabular}{lccccc}
\hline & \multirow{2}{*}{ BAg. - $\left.^{-1}\right)$} & \multicolumn{2}{c}{ I subcultivo } & \multicolumn{2}{c}{ |l subcultivo } \\
\cline { 3 - 6 } & IAA & Sem carvão & Com carvão & Sem carvão & Com carvão \\
\hline 0,1 & 0,0 & 3,48 & 2,48 & 2,48 & 3,45 \\
0,1 & 0,2 & 2,68 & 2,46 & 3,11 & 3,12 \\
0,5 & 0,0 & 3,40 & 1,79 & 2,82 & 2,51 \\
0,5 & 0,1 & 2,55 & 2,54 & 2,21 & 3,49 \\
0,5 & 0,2 & 2,72 & 2,68 & 3,41 & 2,45 \\
0,5 & 0,5 & 2,68 & 2,53 & 2,85 & 2,56 \\
\hline
\end{tabular}

A análise fatorial 2×2x6 mostrou que as diferentes combinações de BAPxIAA na composição dos meios de cultura apresentaram efeitos semelhantes, enquanto subcultivo foi um fator significativo na diferenciação de novas gemas por explante, assim como a adição ou não de carvão ativado no meio básico de cultura MS. Ocorreu interação entre subcultivo e adição de carvão ativado, carvão ativado e BAPxIAA, e entre os três fatores, mas não entre subcultivo e BAPxIAA (Tabela 25).

Tabela 25. Análise da variância de proliferação de gemas por explante em dois subcultivos em meio básico de cultura MS com adição ou não de carvão ativado, suplementado com diferentes combinações de BAPxIAA.

\begin{tabular}{|c|c|c|c|}
\hline Fonte de variação & G. L. & Q. M & $\mathrm{F}$ \\
\hline Subcultivo $(A)$ & 1 & 1,4782 & $5,3148^{\star}$ \\
\hline Carvão ativado (B) & 1 & 1,3142 & $4,7249^{*}$ \\
\hline BAPxIAA (C) & 5 & 0,4001 & $1,4387^{\mathrm{NS}}$ \\
\hline Fator $A \times B$ & 1 & 3,4046 & $12,2406^{\star \star}$ \\
\hline Fator $\mathrm{A} \times \mathrm{C}$ & 5 & 0,2334 & $0,8390^{N S}$ \\
\hline Fator $\mathrm{B} \times \mathrm{C}$ & 5 & 1,6647 & $5,9853^{\star *}$ \\
\hline Fator $\mathrm{A} \times \mathrm{B} \times \mathrm{C}$ & 5 & 1,7089 & $6,1439^{\star *}$ \\
\hline Tratamentos $^{1}$ & 23 & 1,1405 & - \\
\hline Resíduo & 134 & 0,2781 & - \\
\hline
\end{tabular}


A presença de carvão ativado foi favorável à diferenciação de um maior número de gemas no segundo subcultivo, com destaques para meios de cultura que continham BAP $0,1 \mathrm{mg} \cdot \mathrm{L}^{-1}$, e BAP $0,1 \times \mathrm{xIAA} 0,2 \mathrm{mg} \cdot \mathrm{L}^{-1}$, enquanto no primeiro subcultivo as melhores performances ocorreram na ausência de carvão ativado, principalmente com BAP 0,5 mg. $\mathrm{L}^{-1}$, e BAP 0,5xIAA 0,2 mg. $\mathrm{L}^{-1}$ (Tabela 26). Observou-se que, na presença de carvão ativado, raramente ocorreu a formação de calos na base, mas houve indução de raízes (Figura 14f).

Tabela 26. Teste Tukey de comparação de médias ${ }^{1}$ sobre a proliferação de gemas por explante em dois subcultivos em meio básico de cultura MS com adição ou não de carvão ativado, suplementado com diferentes combinações de BAPXIAA.

\begin{tabular}{|c|c|c|c|c|c|c|c|}
\hline \multirow{2}{*}{ 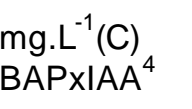 } & \multicolumn{2}{|c|}{ Subcultivo $^{2}(A)$} & \multicolumn{4}{|c|}{ Carvão $0,2 \%^{3}(B)$} & \multirow[t]{2}{*}{ Média } \\
\hline & $\mathrm{I}\left(\mathrm{A}_{1}\right)$ & II $\left(A_{2}\right)$ & Sem $\left(B_{1}\right)$ & & $\mathrm{CxB}_{2}^{5}$ & $\operatorname{Com}\left(\mathrm{B}_{2}\right)$ & \\
\hline $0,1 \times 0,0\left(C_{1}\right)$ & 2,978 & 2,963 & $2,976 \mathbf{a b}$ & $A$ & $A$ & $2,965 \mathbf{a}$ & $2,971 \mathrm{a}$ \\
\hline $0,1 \times 0,2\left(\mathrm{C}_{2}\right)$ & 2,569 & 3,110 & $2,890 \mathbf{a b}$ & A & A & $2,789 \mathbf{a}$ & $2,840 \mathrm{a}$ \\
\hline $0,5 \times 0,0\left(\mathrm{C}_{3}\right)$ & 2,594 & 2,666 & $3,112 \mathbf{a}$ & A & B & $2,148 \quad$ b & $2,630 \mathrm{a}$ \\
\hline $0,5 \times 0,1\left(\mathrm{C}_{4}\right)$ & 2,547 & 2,846 & $2,378 \quad \mathbf{b}$ & $\mathrm{B}$ & $A$ & $3,015 \mathbf{a}$ & $2,696 \mathrm{a}$ \\
\hline $0,5 \times 0,2\left(C_{5}\right)$ & 2,701 & 2,927 & $3,063 \mathbf{a}$ & $A$ & $B$ & $2,565 a b$ & $2,814 \mathrm{a}$ \\
\hline $0,5 \times 0,5\left(\mathrm{C}_{6}\right)$ & 2,603 & 2,707 & $2,766 \mathrm{ab}$ & $A$ & $A$ & $2,545 \mathbf{a b}$ & $2,655 a$ \\
\hline Média $^{1}$ & $2,665 \mathrm{~B}$ & $2,870 \mathrm{~A}$ & $2,864 \mathrm{~A}$ & & & $2,671 \mathrm{~B}$ & \\
\hline Sem carvão & $2,917 \mathrm{~A}$ & $2,811 \mathrm{~A}$ & $2,917 \mathrm{~A}$ & & & $2,413 \mathrm{~B}$ & I subcultivo \\
\hline Com carvão & $2,413 \mathrm{~B}$ & $2,929 \mathrm{~A}$ & $2,811 \mathrm{~A}$ & & & $2,929 \mathrm{~A}$ & II subcultivo \\
\hline
\end{tabular}

'Médias seguidas pela mesma letra não diferem estatisticamente entre si: letras minúsculas comparação de médias na vertical e letras maiúsculas comparação de médias na horizontal

${ }^{2}$ Fator A com dois níveis: I subcultivo e II subcultivo

${ }^{3}$ Fator B com dois níveis: sem carvão (1) e com carvão (2)

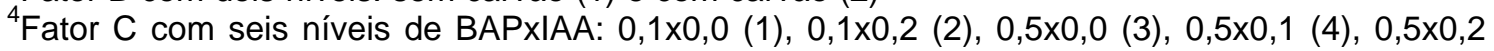
(5) e $0,5 \times 0,5(6)$

${ }^{5}$ comparação entre os mesmos níveis de C (BAPxIAA) sem carvão (nível 1 de B) versus com carvão (nível 2 de B)

Pelo exposto, é recomendado para o estabelecimento de cultura o meio básico MS suplementado com BAP a 0,1 e IAA a 0,2 mg. $\mathrm{L}^{-1}$ e adição de carvão ativado a $0,2 \%(p / v)$, e para a multiplicação de brotos, BAP a $0,5 \mathrm{mg} \cdot \mathrm{L}^{-1}$ combinado ou não com IAA 0,2 mg. $\mathrm{L}^{-1}$, pois esses dois tratamentos apresentaram maior estabilidade quanto a diferenciação de gemas, enquanto com BAP à concentração acima de 0,5 mg. $\mathrm{L}^{-1}$, ocorreu instabilidade das respostas nos subcultivos subseqüentes. 


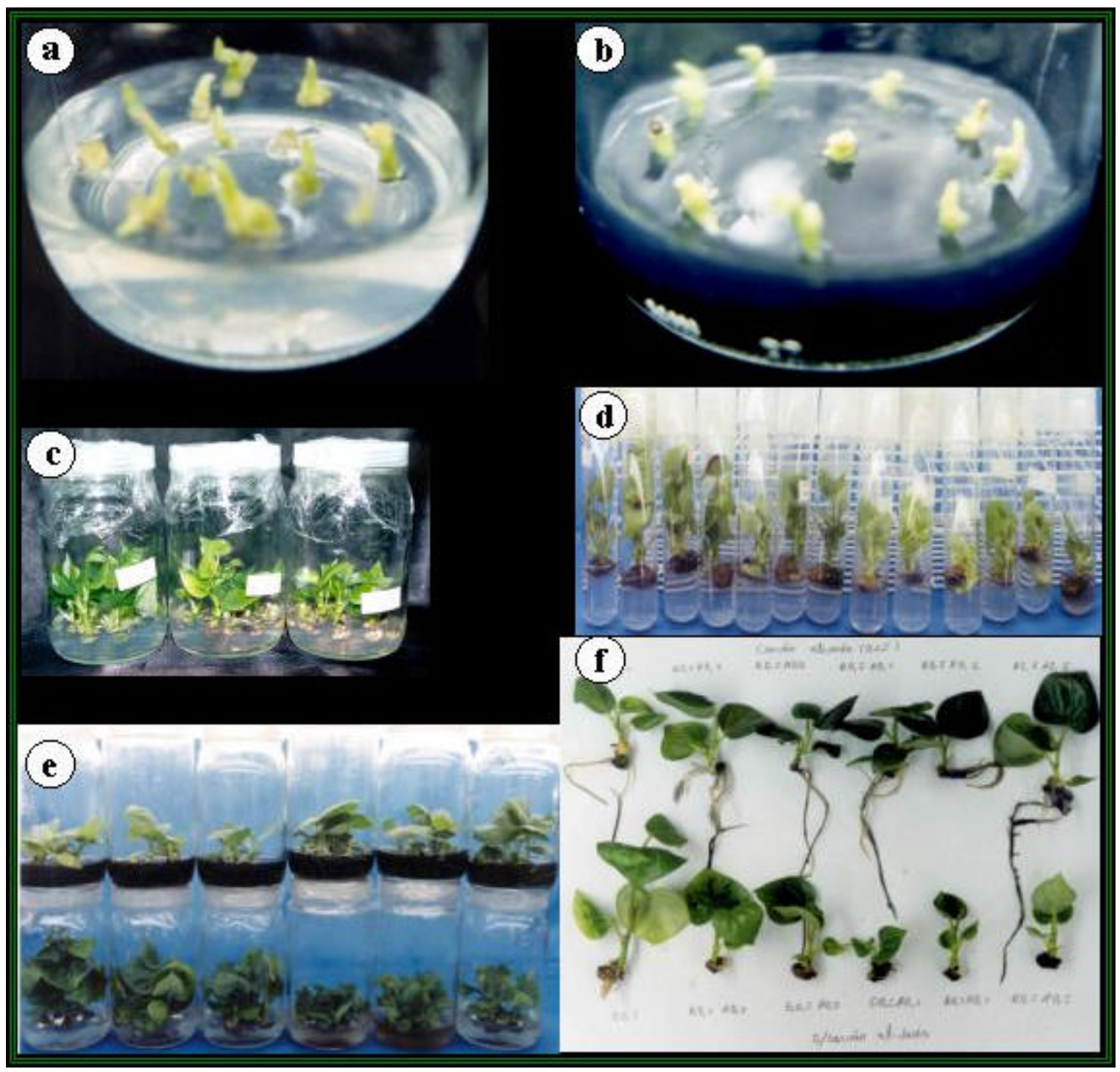

Figura 14 - Multiplicação de gemas em meio básico MS.

a) Fase de estabelecimento em BAP $0,5 \mathrm{mg} \cdot \mathrm{L}^{-1}$ e IAA 0,2 mg. $\mathrm{L}^{-1}$

b) Em BAP 0,5 mg. $\mathrm{L}^{-1}$ e IAA $0,2 \mathrm{mg} \cdot \mathrm{L}^{-1}$ e carvão ativado $0,2 \%$

c) Em BAP 0,5 e IAA0,2 mg. $\mathrm{L}^{-1}$

d) BAPxIAA (esquerda para direita: $0,5 \times 0,0 ; 0,5 \times 0,1 ; 0,5 \times 0,2 ; 0,5 \times 0,3 ; 0,5 \times 0,5 ; 1,0 \times 1,0$; $2,0 \times 2,0 ; 1,0 \times 0,0 ; 1,0 \times 0,2 ; 2,0 \times 0,0 ; 2,0 \times 0,2 ; 4,0 \times 0,0 ;$ e 4,0x0,2 mg. $\left.\mathrm{L}^{-1}\right)$

e) No primeiro subcultivo, com carvão $0,2 \%$ (acima) e sem carvão (abaixo) e BAPxIAA (esquerda para direita) $0,1 \times 0,0 ; 0,1 \times 0,2 ; 0,5 \times 0,0 ; 0,5 \times 0,1 ; 0,5 \times 0,2 ;$ e $0,5 \times 0,5$

f) Idem e no segundo subcultivo 


\subsubsection{Alongamento e enraizamento de brotos}

Inicialmente, o enraizamento foi realizado a partir de brotos inferiores ou superiores a 2,0 cm em meio básico MS suplementado com NAA 0,5 mg. $\mathrm{L}^{-1}$ associado com $\mathrm{GA}_{3}\left(0,0,5\right.$ e $\left.1,0 \mathrm{mg} \cdot \mathrm{L}^{-1}\right)$. Os melhores resultados em número de raízes/broto ocorreram nos tratamentos que continham $\mathrm{GA}_{3}$ a 0,5 ou $1,0 \mathrm{mg} \cdot \mathrm{L}^{-1}$. O enraizamento de brotos, em todos os tratamentos, foi superior a $90,0 \%$, com destaque para o tratamento que continha $\mathrm{GA}_{3}$ a $1,0 \mathrm{mg} \cdot \mathrm{L}^{-1}$, o qual ocorreu a diferenciação de raízes em $97,86 \%$ dos brotos em cultura (Tabela 27). Os brotos cresceram e visualmente não apresentaram diferença significativa entre os tratamentos, os quais foram transferidos para a fase de aclimatação e formação de mudas.

Tabela 27. Análise da variância, média de raiz por broto e percentagem de brotos enraizados em meio básico de cultura MS suplementado com NAA $(0,5$ $\left.\mathrm{mg} \cdot \mathrm{L}^{-1}\right)$ e $\mathrm{GA}_{3}\left(0,0 ; 0,5 ;\right.$ ou $\left.1,0 \mathrm{mg} \cdot \mathrm{L}^{-1}\right)$ após 4 semanas de cultivo.

\begin{tabular}{lcccccc}
\hline \multirow{2}{*}{$\begin{array}{l}\text { Fonte de } \\
\text { Variação }\end{array}$} & G. L. & Q.M & F & \multicolumn{3}{c}{${ }^{2}$ Média de raiz/broto (\% de brotos com raiz) } \\
\cline { 3 - 6 } & & & Trat. $1^{3}$ & Trat.2 & Trat. $3^{5}$ \\
\hline Tratamento & 2 & 34,9996 & $4,49^{*}$ & 5,7129 a & 6,3850 ab & 9,5186 b \\
Resíduo & 28 & 7,7917 & - & $(91,72)$ & $(90,53)$ & $(97,86)$ \\
\hline
\end{tabular}

Nos brotos com tamanho igual ou superior a 2,0 cm ocorreu diferenciação de raízes, todos em meio contendo 0,5 e 1,0 mg. $\mathrm{L}^{-1}$ de NAA, com médias de 11,21 e 8,30 raízes/broto, respectivamente, sendo que em meio sem NAA somente $79,31 \%$ dos brotos enraizaram, apresentando a menor média de raiz/broto de 1,89 raízes (Tabela 28). Observou-se, nos meios de cultura contendo NAA, raízes mais espessas em relação àquelas diferenciadas em meio de cultura sem regulador de crescimento, sendo a concentração de NAA $0,1 \mathrm{mg} \cdot \mathrm{L}^{-1}$ mais apropriada para o enraizamento, pois as raízes eram de espessura mais fina e com raízes secundárias (Figura 15a), semelhantes aos resultados obtidos por Khoon \& Talib (1985). Uma das causas de ocorrência de maior diâmetro de raiz está no fato de que àmedida que se aumentou a concentração, apresentou maior indução de primórdios radiculares, mas ao mesmo 
tempo houve inibição do crescimento, encurtando raízes, conseqüentemente, mais espessas.

Tabela 28. Análise da variância, média de raiz por broto e percentagem de brotos enraizados em meio básico de cultura MS suplementado com NAA $(0,0$; 0,$1 ; 0,5$ e 1,0 mg. $\mathrm{L}^{-1}$ ) após 4 semanas de cultivo.

\begin{tabular}{|c|c|c|c|c|c|c|c|}
\hline \multirow[t]{2}{*}{ F. V. } & \multirow[t]{2}{*}{ G. L } & \multirow[t]{2}{*}{ Q.M } & \multirow[t]{2}{*}{$\mathrm{F}$} & \multicolumn{4}{|c|}{${ }^{2}$ Média de raiz/broto (\% de brotos com raiz) } \\
\hline & & & & Trat. $1^{3}$ & Trat. $^{3}$ & Trat. $3^{3}$ & Trat. $4^{3}$ \\
\hline $\begin{array}{l}\text { Tratamento } \\
\text { Resíduo }\end{array}$ & $\begin{array}{c}3 \\
23\end{array}$ & $\begin{array}{l}129,136 \\
2,082\end{array}$ & $62,02^{* *}$ & $\begin{array}{c}1,89 \mathbf{a} \\
(79,31)\end{array}$ & $\begin{array}{l}7,32 \mathbf{b} \\
(95,83)\end{array}$ & $\begin{array}{l}11,21 \mathbf{c} \\
(100,0)\end{array}$ & $\begin{array}{l}8,30 \mathbf{b} \\
(100,0)\end{array}$ \\
\hline
\end{tabular}

A etapa de enraizamento, que estava sendo conduzida a partir de brotos, foi modificada para a partir de gemas. As gemas cultivadas em meio básico de cultura MS, na presença ou ausência de carvão ativado (0,2\%), por um período de 60 dias, diferenciaram raízes além do desenvolvimento caulinar (Figura 15c). As raízes se apresentaram normais, com crescimento variando de 1,73 a 3,72 cm na ausência e 4,49 a 6,65 cm na presença de carvão ativado. Outrossim, a percentagem de brotos com raízes foi maior em todos os tratamentos na presença de carvão ativado $(81,90$ a $97,49 \%)$ do que na ausência (53,89 a 90,0\%), assim como apresentou maior número de raízes.

O desenvolvimento caulinar variou, nos tratamentos, de 2,04 a 5,81 cm em meio de cultura sem carvão e 4,16 a 5,46 cm com carvão, neste último havendo maior homogeneidade entre as diferentes combinações de BAPxIAA (Tabela 29). Portanto, a presença de carvão ativado foi benéfica à indução de raízes como relatado por Grattapaglia \& Machado (1998), porque simula a condição de escuro, retém parte dos compostos que compõem o meio de cultura, fixa citocinina residual e absorve compostos tóxicos inibidores do enraizamento, além de favorecer o alongamento das raízes por fixar também a auxina. 
Tabela 29. Resposta à diferenciação de raízes e desenvolvimento caulinar de gemas em meio básico MS com adição ou não de carvão ativado a $0,2 \%$, suplementado com diferentes combinações de BAPXIAA, após 60 dias de cultivo.

\begin{tabular}{|c|c|c|c|c|c|c|c|c|}
\hline \multirow{2}{*}{$\begin{array}{c}\text { BAPxIAA } \\
\left(\mathrm{mg}^{-1} \mathrm{~L}^{-1}\right)\end{array}$} & \multicolumn{4}{|c|}{ Sem carvão } & \multicolumn{4}{|c|}{ Com carvão $(0,2 \%)$} \\
\hline & ${\operatorname{Raiz}(\%)^{2}}^{2}$ & Raiz(n) & Raiz $(\mathrm{cm})^{4}$ & Caule $(\mathrm{cm})$ & Raiz $(\%)^{2}$ & $\operatorname{Raiz}_{(\mathrm{n})^{3}}$ & Raiz $(\mathrm{cm})^{4}$ & Caule $(\mathrm{cm})^{5}$ \\
\hline $0,1 \times 0,0$ & 90,00 & 3,48 & 2,70 & 5,21 & 91,55 & 5,94 & 6,65 & 5,46 \\
\hline $0,1 \times 0,2$ & 86,94 & 4,31 & 2,58 & 5,20 & 97,49 & 3,91 & 4,49 & 4,91 \\
\hline $0,5 \times 0,0$ & 64,44 & 2,53 & 1,73 & 3,08 & 78,89 & 3,99 & 5,37 & 4,16 \\
\hline $0,5 \times 0,1$ & 53,89 & 2,35 & 3,72 & 2,04 & 93,92 & 5,14 & 5,37 & 5,33 \\
\hline $0,5 \times 0,2$ & 82,22 & 2,55 & 3,22 & 5,20 & 84,00 & 3,52 & 4,83 & 4,41 \\
\hline $0,5 \times 0,5$ & 85,00 & 2,66 & 2,26 & 5,81 & 81,90 & 4,02 & 5,01 & 4,85 \\
\hline Média $^{1}$ & $77,09 \mathrm{~B}$ & $2,98 \mathrm{~B}$ & $2,70 \mathrm{~B}$ & $4,42 \mathrm{~A}$ & $87,96 \mathrm{~A}$ & $4,22 \mathrm{~A}$ & $5,29 \mathrm{~A}$ & $4,85 \mathrm{~A}$ \\
\hline
\end{tabular}

As diferentes combinações de BAPxIAA em meio básico de cultura MS não tiveram efeitos significativos quanto a percentagem, número e comprimento de raiz a partir de gemas, mas, quanto ao desenvolvimento do caule, os meios de cultura que continham somente BAP $0,1 \mathrm{mg} \cdot \mathrm{L}^{-1}$ e aquele com BAP e IAA a 0,5 mg. $\mathrm{L}^{-1}$ de cada, apresentaram maior crescimento do caule, com 5,33 cada, o que favoreceu uma adaptação melhor por ocasião da aclimatação (Tabela 30).

Tabela 30. Teste de comparação de média quanto a diferenciação de raízes e desenvolvimento caulinar a partir de gemas em meio básico MS com adição au não de carvão ativado a 0,2\%, suplementado com diferentes combinações de BAPxIAA, após 60 dias de cultivo.

\begin{tabular}{cccccc}
\hline \multirow{2}{*}{ BAP } & $\left(\mathrm{mg}^{-1} \mathrm{~L}^{-1}\right)$ & \multicolumn{5}{c}{ Média $^{1}$} \\
\cline { 3 - 6 } & IAA & Raiz (\%) & Raiz(n) & Raiz(cm) & Caule $(\mathrm{cm})$ \\
\hline 0,1 & 0,0 & $90,78 \mathbf{a}$ & $4,71 \mathbf{a}$ & $4,68 \mathbf{a}$ & $5,33 \mathbf{a}$ \\
0,1 & 0,2 & $92,22 \mathbf{a}$ & $4,11 \mathbf{a}$ & $3,54 \mathbf{a}$ & $5,05 \mathbf{a b}$ \\
0,5 & 0,0 & $71,67 \mathbf{a}$ & $3,26 \mathbf{a}$ & $3,55 \mathbf{a}$ & $3,62 \mathbf{b}$ \\
0,5 & 0,1 & $73,91 \mathbf{a}$ & $3,75 \mathbf{a}$ & $4,55 \mathbf{a}$ & $3,69 \mathbf{b}$ \\
0,5 & 0,2 & $83,11 \mathbf{a}$ & $3,04 \mathbf{a}$ & $4,03 \mathbf{a}$ & $4,80 \mathbf{a b}$ \\
0,5 & 0,5 & $83,44 \mathbf{a}$ & $3,34 \mathbf{a}$ & $3,64 \mathbf{a}$ & $5,33 \mathbf{a}$ \\
\hline
\end{tabular}

TMédias seguidas pela mesma letra não diferem entre si 
A utilização IBA para a formação de brotos enraizados foi mais eficiente em comparação com NAA, pois, em todas as concentrações, houve $100 \%$ de indução de raízes, enquanto ao suplementar o meio de cultura com o NAA, as mesmas respostas ocorreram somente nas concentrações de 0,1 e 0,5 $\mu \mathrm{M}$, sendo reduzida a percentagem àmedida que a concentração foi elevada (acima de 1,0 $\mu \mathrm{M}$ ). Ressalte-se que as raízes tornaram-se menores e mais grossas com a elevação da concentração de NAA e, à concentração de 5,0 $\mu \mathrm{M}$, somente $27,51 \%$ das gemas diferenciaram raízes e houve formação de calos, como observado também por Mathews \& Rao (1984) ao usarem NAA a 1,0 mg. $\mathrm{L}^{-1}$, cerca de 5,4 $\mu \mathrm{M}$ (Figura 15b). Ademais, o crescimento do sistema caulinar foi reduzido. A ação de IBA permitiu melhor crescimento caulinar e radicular, apesar de relativamente menor número de raízes (Tabela 31 e Figura 15d).

Tabela 31. Diferenciação de brotos e raízes a partir de gemas cultivadas em meio básico de cultura MS suplementado com NAA ou IBA a diferentes concentrações, após 10 semanas de cultivo.

\begin{tabular}{lcccc|cccc}
\hline \multirow{2}{*}{$\begin{array}{l}N^{*} \\
(\mu \mathrm{M})\end{array}$} & \multicolumn{9}{c}{ 1/AMS } \\
\cline { 2 - 8 } & Raiz(\%) & Raiz(n) & Raiz(cm) & Caule(cm) & Raiz(\%) & Raiz(n) & Raiz(cm) & Caule(cm) \\
\hline 0,0 & 97,94 & 2,04 & 2,18 & 2,75 & 18,28 & 1,67 & 2,18 & 1,88 \\
0,1 & 100,0 & 2,04 & 2,32 & 2,64 & 85,54 & 1,69 & 2,41 & 1,63 \\
0,5 & 100,0 & 3,01 & 1,68 & 2,03 & 97,94 & 2,75 & 1,87 & 1,73 \\
1,0 & 95,88 & 3,12 & 1,61 & 1,82 & 89,67 & 3,13 & 1,78 & 1,35 \\
2,5 & 96,24 & 2,99 & 1,38 & 1,60 & 94,43 & 3,08 & 1,65 & 0,81 \\
5,0 & 27,51 & 2,68 & 1,28 & 1,46 & 96,10 & 3,22 & 1,66 & 0,81 \\
& & & & & & & & \\
$\mathrm{IBA}^{2}(\mu \mathrm{M})$ & & & & & & & & \\
0,0 & 97,94 & 2,04 & 2,18 & 2,75 & 18,28 & 1,67 & 2,18 & 1,88 \\
0,1 & 100,0 & 1,75 & 2,15 & 2,42 & 100,0 & 1,98 & 2,54 & 1,96 \\
0,5 & 100,0 & 1,95 & 2,16 & 2,58 & 100,0 & 1,72 & 2,28 & 1,90 \\
1,0 & 100,0 & 2,27 & 2,17 & 2,62 & 93,21 & 1,63 & 2,08 & 1,96 \\
2,5 & 100,0 & 2,55 & 2,1686 & 2,5561 & 100,0 & 1,84 & 2,35 & 2,08 \\
5,0 & 100,0 & 3,03 & 1,8745 & 2,2287 & 100,0 & 2,26 & 2,06 & 2,02 \\
\hline
\end{tabular}

Respostas das gemas referentes àadição de NAA (0 a 5,0 $\mu \mathrm{M})$ ao meio de cultura

${ }^{2}$ Respostas das gemas referentes àadição de IBA (0 a 5,0 $\left.\mu \mathrm{M}\right)$ ao meio de cultura

Os fatores dos meios de cultura como metade ou completa concentração dos sais de MS, NAA ou IBA a diferentes concentrações ( 0 a $5 \mu \mathrm{M}$ ) influenciaram efetivamente todos os parâmetros avaliados, quais sejam: percentagem de explantes 
que diferenciaram raízes, número e comprimento das raízes, e comprimento do sistema caulinar. Interagiram entre si significativamente, com exceção entre os fatores como concentração de sais de MS e níveis de regulador de crescimento quanto ao número e tamanho de raízes, assim como entre o tipo de regulador de crescimento e concentração de sais de MS para tamanho de raiz e caule (Tabela 32).

Tabela 32. Análise da variância quanto ao efeito de IBA ou NAA em seis níveis (0 a 5 $\mu \mathrm{M})$ em meio básico de cultura MS com metade ou completa concentração dos sais na diferenciação de raízes e desenvolvimento caulinar, após 10 semanas de cultivo.

\begin{tabular}{|c|c|c|c|c|c|c|c|c|c|c|}
\hline \multirow{3}{*}{$\begin{array}{l}\text { Fonte de } \\
\text { variação }\end{array}$} & & \multirow[t]{3}{*}{ G. L. } & \multicolumn{4}{|c|}{ Q. M. } & \multicolumn{4}{|c|}{$F$} \\
\hline & & & \multicolumn{3}{|c|}{ Raiz } & \multirow{2}{*}{$\begin{array}{r}\text { Caule } \\
(\mathrm{cm})\end{array}$} & \multicolumn{3}{|c|}{ Raiz } & \multirow{2}{*}{$\begin{array}{l}\text { Caule } \\
(\mathrm{cm})\end{array}$} \\
\hline & & & $(\%)$ & (n) & $(\mathrm{cm})$ & & $(\%)$ & (n) & (cm) & \\
\hline MS (A) & & 1 & 0,14 & 2,62 & 1,17 & 18,01 & $20,73^{\star \star}$ & $15,11^{\star *}$ & $18,21^{\star \star}$ & $230,88^{\star \star}$ \\
\hline R. C. (B) & & 1 & 0,10 & 14,72 & 5,73 & 13,52 & $15,27^{\star *}$ & $84,82^{* *}$ & $88,88^{\star \star}$ & $173,40^{\star *}$ \\
\hline Níveis (C) & & 5 & 0,23 & 4,90 & 1,61 & 2,04 & $36,14^{* *}$ & $28,24^{\text {** }}$ & $24,88^{\star *}$ & $26,16^{\star *}$ \\
\hline$A \times B$ & & 1 & 0,03 & 1,53 & 0,03 & 0,18 & $3,94^{*}$ & $8,81^{* *}$ & $0,44^{N S}$ & $2,32^{N S}$ \\
\hline$A \times C$ & & 5 & 0,32 & 0,12 & 0,10 & 0,20 & $48,90^{* *}$ & $0,69^{\mathrm{NS}}$ & 1,59 NS & $2,58^{\star}$ \\
\hline $\mathrm{B} \times \mathrm{C}$ & & 5 & 0,04 & 2,14 & 0,70 & 1,75 & $6,94^{\star *}$ & $12,34^{\star *}$ & $10,91^{* *}$ & $22,41^{* *}$ \\
\hline $\mathrm{A} \times \mathrm{B} \times \mathrm{C}$ & & 5 & 0,05 & 0,93 & 0,07 & 0,27 & $7,40^{\star *}$ & $5,34^{* *}$ & $1,11 \mathrm{~ns}$ & $3,47^{\star *}$ \\
\hline Trat. & 23 & 23 & 0,15 & 2,58 & 0,84 & 2,30 & - & - & - & - \\
\hline Res. & $207^{1}$ & $188^{2}$ & 0.007 & 0.174 & 0,065 & 0.078 & - & - & - & - \\
\hline
\end{tabular}

Significativo ao nível de $5 \%$ e $1 \%$ de probabilidade, respectivamente

${ }^{\mathrm{NS}}$ Não significativo

${ }^{1}$ Graus de liberdade do resíduo referentes àpercentagem de enraizamento

${ }^{2}$ Graus de liberdade do resíduo referentes ao número, comprimento de raízes e ao comprimento caulinar

Para a diferenciação de brotos com raiz a partir de gemas, a maior percentagem ocorreu em meio de cultura com metade da concentração de sais de MS e tendo como regulador de crescimento o IBA, enquanto para NAA foi indiferente. As concentrações de 0,1 a 2,5 $\mu \mathrm{M}$ foram mais favoráveis e a concentração de 5,0 $\mu \mathrm{M}$ inibiu a indução de raízes, principalmente de NAA em meio de cultura com a metade da concentração dos sais de MS em que foi observada a formação de calos (Tabela 33). 
Tabela 33. Teste de comparação de médias quanto a percentagem de explantes com raízes quando gemas foram cultivadas em meio básico de cultura MS, com metade ou completa concentração de sais, suplementado com NAA ou IBA àdiferentes concentrações, após 10 semanas de cultivo.

\begin{tabular}{|c|c|c|c|c|c|c|c|c|c|}
\hline \multirow[t]{2}{*}{$(\mu \mathrm{M})$} & \multicolumn{4}{|c|}{ Explantes com raiz (\%) } & \multicolumn{5}{|c|}{ Explantes com raiz (\%) } \\
\hline & $1 / 2 \mathrm{MS}$ & & & MS & $\overline{N A A}$ & & & IBA & Média \\
\hline 0,0 & $97,94 \mathrm{a}$ & $\mathrm{A}$ & $\mathrm{B}$ & $18,28 \mathrm{~b}$ & $54,30 \mathrm{~b}$ & $A$ & $A$ & $54,31 b$ & $54,31 \mathrm{c}$ \\
\hline 0,1 & 99,99 a & A & A & $92,68 \mathrm{a}$ & $92,68 \mathrm{a}$ & A & A & 99,99 a & $96,31 \mathrm{a}$ \\
\hline 0,5 & 99,99 a & A & A & $98,96 \mathrm{a}$ & 98,96 a & A & A & 99,99 a & 99,48 a \\
\hline 1,0 & $97,94 \mathrm{a}$ & A & A & 91,42 a & $92,75 \mathrm{a}$ & A & A & $96,58 \mathrm{a}$ & $96,31 \mathrm{a}$ \\
\hline 2,5 & $98,11 \mathrm{a}$ & A & A & $97,21 \mathrm{a}$ & $95,35 \mathrm{a}$ & A & A & 99,99 a & $97,65 \mathrm{a}$ \\
\hline 5,0 & $60,80 \mathrm{~b}$ & B & A & $98,04 \mathrm{a}$ & $59,10 \mathrm{~b}$ & B & A & 99,99 a & $78,73 \mathrm{~b}$ \\
\hline Média $^{1}$ & $92,06 \mathrm{~A}$ & & & 80,74 B & $81,54 \mathrm{~B}$ & & & $91,25 \mathrm{~A}$ & Média $^{1}$ \\
\hline NAA & $84,68 \mathrm{~A}$ & & & $78,41 \mathrm{~A}$ & 84,68 B & & & $99,65 \mathrm{~A}$ & $1 / 2 M S$ \\
\hline IBA & $99,65 \mathrm{~A}$ & & & $83,10 \mathrm{~B}$ & $78,41 \mathrm{~A}$ & & & $83,10 \mathrm{~A}$ & MS \\
\hline
\end{tabular}

Quanto ao número de raízes, não houve diferença significativa se os diferentes níveis de NAA e IBA estavam em combinação com 1/2MS ou MS completo, particularmente quando se tratava de NAA. No caso de IBA diferença significativa foi observada em prol do meio de cultura com metade da concentração dos sais. Observou-se maior número de raízes àmedida que se aumentou a concentração IBA (Tabela 34). 
Tabela 34. Teste de comparação de média quanto ao número de raízes por explante em meio básico de cultura MS, com metade ou completa concentração de sais, suplementado œm NAA ou IBA a diferentes concentrações, após 10 semanas de cultivo.

\begin{tabular}{|c|c|c|c|c|c|c|c|}
\hline \multirow[t]{2}{*}{$(\mu \mathrm{M})$} & \multicolumn{2}{|c|}{ Número de raízes } & \multicolumn{5}{|c|}{ Número de raízes } \\
\hline & $1 / 2 \mathrm{MS}$ & MS & NAA & & & IBA & Média \\
\hline 0,0 & 4.0772 & 3.3365 & $1.8534 \mathbf{b}$ & A & $A$ & $1.8534 \mathbf{b}$ & $1.8534 \mathrm{c}$ \\
\hline 0,1 & 3.7871 & 3.6671 & 1.8657 b & A & A & $1.8614 \mathbf{b}$ & $1.8636 \mathrm{c}$ \\
\hline 0,5 & 4.9565 & 4.4680 & $2.8769 a$ & A & B & 1.8354 b & $2.3561 \mathrm{~b}$ \\
\hline 1,0 & 5.3952 & 4.7540 & $3.1239 \mathbf{a}$ & A & B & $1.9507 \mathbf{b}$ & $2.5373 \mathrm{ab}$ \\
\hline 2,5 & 5.5383 & 4.9178 & $3.0334 \mathbf{a}$ & A & B & 2.1946 b & $2.6140 \mathrm{ab}$ \\
\hline 5,0 & 5.7044 & 5.4760 & $2.9483 \mathbf{a}$ & A & B & $2.6419 a$ & $2.7951 \mathrm{a}$ \\
\hline Média $^{1}$ & $2.4549 \mathrm{~A}$ & $2.2183 \mathrm{~B}$ & $2.6169 \mathrm{~A}$ & & & 2.0562 B & \\
\hline $\begin{array}{l}\text { NAA } \\
\text { IBA }\end{array}$ & $\begin{array}{l}2.6449 A \\
2.2649 A\end{array}$ & $\begin{array}{l}2.5890 \mathrm{~A} \\
1.8476 \mathrm{~B}\end{array}$ & $\begin{array}{l}2.6449 A \\
2.5890 A\end{array}$ & & & $\begin{array}{l}2.2649 \mathrm{~B} \\
1.8476 \mathrm{~B}\end{array}$ & $\begin{array}{c}1 / 2 \mathrm{MS} \\
\mathrm{MS}\end{array}$ \\
\hline i & & & & & & s minús & mpar \\
\hline
\end{tabular}

As raízes diferenciadas apresentaram maior crescimento em meio de cultura contendo concentração completa dos sais e em meios de cultura contendo IBA, com destaque à concentração de $0,1 \mu \mathrm{M}$ que permitiu maior crescimento tanto com NAA quanto com IBA (Tabela 35).

Tabela 35. Teste de comparação de média quanto ao comprimento de raízes por explante enraizado em meio básico de cultura MS, com metade ou completa concentração de sais, suplementado com NAA ou IBA a diferentes concentrações, após 10 semanas de cultivo.

\begin{tabular}{|c|c|c|c|c|c|c|c|c|c|c|}
\hline \multirow{2}{*}{$(\mu \mathrm{M})$} & \multicolumn{2}{|c|}{ Raiz $(\mathrm{cm})$} & \multicolumn{8}{|c|}{ Raiz $(\mathrm{cm})$} \\
\hline & $1 / \mathrm{MS}$ & MS & \multicolumn{3}{|c|}{ NAA } & \multicolumn{3}{|c|}{ IBA } & \multicolumn{2}{|c|}{ Média' } \\
\hline 0,0 & 2,18 & 2,18 & 2,18 & $\mathbf{A}$ & $A$ & A & 2,18 & $a b$ & 2,18 & $a b$ \\
\hline 0,1 & 2,23 & 2,48 & 2,37 & A & A & A & 2,34 & $\mathbf{a}$ & 2,36 & $\mathbf{a}$ \\
\hline 0,5 & 1,92 & 2,08 & 1,77 & b & B & A & 2,22 & $a b$ & 2,00 & bc \\
\hline 1,0 & 1,89 & 1,93 & 1,69 & bc & B & A & 2,13 & $a b$ & 1,91 & c \\
\hline 2,5 & 1,78 & 2,00 & 1,52 & bc & B & A & 2,26 & $\mathbf{a}$ & 1,89 & cd \\
\hline 5,0 & 1,58 & 1,86 & 1,47 & c & B & A & 1,97 & b & 1.72 & d \\
\hline Média & $1,93 \mathrm{~B}$ & $2,09 \mathrm{~A}$ & & 8330 & & & $8 \mathrm{~A}$ & & & \\
\hline
\end{tabular}

Médias seguidas pela mesma letra não diferem entre. Letras minúsculas: comparação vertical; letras maiúsculas: comparação horizontal 
O crescimento do sistema caulinar a partir de gemas, que também diferenciaram raízes, foi mais expressivo em meio de cultura com a metade da concentração dos sais de MS e com IBA. O destaque foi para as gemas que diferenciaram raízes em meio de cultura sem regulador de crescimento, que apresentaram maior crescimento do sistema caulinar. Este resultado era esperado uma vez que ainda contém resíduo de citocinina do subcultivo anterior. Houve uma maior uniformidade do crescimento com IBA, enquanto com NAA, foi reduzido à medida que as concentrações foram elevadas, atingindo a menor média $(1,84 \mathrm{~cm})$ à concentração de 5,0 $\mu \mathrm{M}$ (Tabela 36).

Tabela 36. Teste de comparação de média quanto ao comprimento caulinar dos explantes que enraizaram em meio básico de cultura MS, com metade ou completa concentração de sais, suplementado com NAA ou IBA a diferentes concentrações, após 10 semanas de cultivo.

\begin{tabular}{|c|c|c|c|c|c|c|c|c|c|c|c|c|}
\hline \multirow{3}{*}{$\begin{array}{c}\text { Nível } \\
(\mu \mathrm{M})\end{array}$} & \multicolumn{6}{|c|}{ Caule $(\mathrm{cm})$} & \multicolumn{6}{|c|}{ Caule $(\mathrm{cm})$} \\
\hline & \multicolumn{2}{|c|}{$1 / \mathrm{AMS} \%$} & & & \multicolumn{2}{|c|}{ MS \% } & \multicolumn{2}{|c|}{ NAA \% } & \multicolumn{3}{|r|}{ IBA } & Média' $^{\top}$ \\
\hline & 2,75 & & $A$ & & 1,88 & $\mathbf{a}$ & $2,32 a$ & & $A$ & $A$ & $2,32 \mathbf{a}$ & $2,32 \mathbf{a}$ \\
\hline 0,1 & 2,53 & & A & B & 1,80 & a & $2,14 a$ & & A & A & $2,19 \mathbf{a}$ & $2,16 \mathbf{a b}$ \\
\hline 0,5 & 2,30 & bc & A & B & 1,81 & a & 1,88 & b & B & A & $2,24 \mathbf{a}$ & 2,06 bc \\
\hline 1,0 & 2,22 & c & A & B & 1,66 & $a b$ & 1,59 & c & B & A & $2,29 \mathbf{a}$ & 1,94 \\
\hline 2,5 & 2,08 & cd & A & B & 1,45 & b & 1,21 & d & B & A & $2,32 \mathbf{a}$ & 1,76 \\
\hline 5,0 & 1,84 & d & A & B & 1,41 & b & 1,33 & d & B & A & $2,12 \mathbf{a}$ & 1,63 \\
\hline Média $^{1}$ & & $2,29 \mathrm{~A}$ & & & $1,67 \mathrm{~B}$ & & & 1,71 B & & & $2,25 \mathrm{~A}$ & \\
\hline
\end{tabular}

Neste experimento visando a diferenciação em "planlets" a partir de gemas, o meio básico de cultura MS com a metade da concentração de sais foi mais efetivo, principalmente quando suplementado com IBA $(0,1$ a 2,5 $\mu \mathrm{M})$, pois, além do enraizamento, permitiu um melhor crescimento do sistema caulinar (Figura 15d). Resultados para várias espécies indicaram que IBA é mais efetivo para o enraizamento in vitro (Grattapaglia \& Machado, 1998).

Ressalte-se que, para obtenção de "plantlets" a partir de brotos desenvolvidos, recomenda-se meio básico de cultura MS com NAA a 0,1 mg. $\mathrm{L}^{-1}$, e a partir de gemas, meio de cultura com BAP a 0,5 e IAA 0,2 mg. $\mathrm{L}^{-1}$ com adição de carvão 
ativado a $0,2 \%(\mathrm{p} / \mathrm{v})$ ou metade da concentração de $\mathrm{MS}$ com 1,0 $\mu \mathrm{M}\left(0,2 \mathrm{mg} \cdot \mathrm{L}^{-1}\right)$. Considere-se que o tempo de cultivo para produção de "plantlets" a partir de brotações deve ser a cerca de 4 semanas e a partir de gemas entre 6 a 8 semanas.

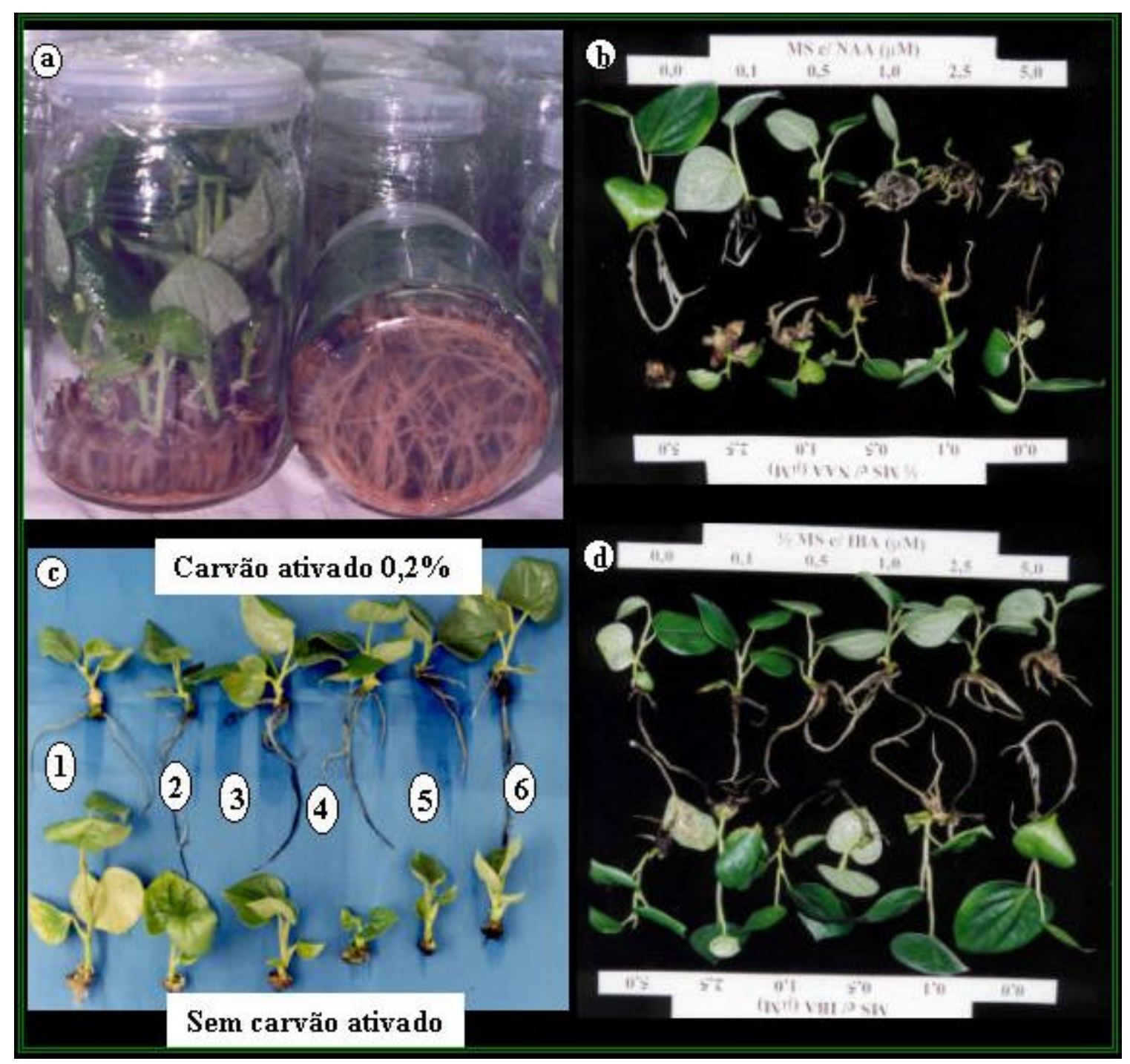

Figura 15 - Alongamento e enraizamento em meio básico de cultura MS.

a) A partir de brotos em NAA a $0,1 \mathrm{mg} \cdot \mathrm{L}^{-1}$

b) A partir de gemas em $1 / \mathrm{MS}$ ou MS e NAA $(0,0 ; 0,1 ; 0,5 ; 1,0 ; 2,5$; e $5,0 \mu \mathrm{M})$

c) A partir de gemas em MS, sem e com carvão ativado a 0,2\% e BAPxIAA $(0,1 \times 0,0$; $0,1 \times 0,2 ; 0,5 \times 0,0 ; 0,5 \times 0,1 ; 0,5 \times 0,2 ;$ e $\left.0,5 \times 0,5 \mathrm{mg}^{-L^{-1}}\right)$

d) A partir de gemas em $1 / 2 \mathrm{MS}$ ou MS e IBA $(0,0 ; 0,1 ; 0,5 ; 1,0 ; 2,5$; e $5,0 \mu \mathrm{M})$ 


\subsubsection{Aclimatação dos brotos enraizados e formação de mudas}

Os primeiros testes de aclimatação indicaram a necessidade de fazer um tratamento dos "plantlets" antes da aclimatação, pois havia muita incidência de fungos, principalmente em substrato do tipo Plantmax. A imersão dos "plantlets" em solução de benlate a $0,2 \%(\mathrm{p} / \mathrm{v})$ antes do processo de aclimatação resolveu este problema. A aclimatação foi muito influenciada pelo tipo de substrato, sendo mais eficaz em substrato do tipo vermiculita do que em substrato composto de vermiculita + Plantmax $(1: 1)$.

Ressalte-se que os "plantlets" originados em meios de cultura com BAP a 0,1 mg. $\mathrm{L}^{-1}$ e BAP a $0,5 \mathrm{mg} \cdot \mathrm{L}^{-1}$ junto com IAA a $0,2 \mathrm{mg} \cdot \mathrm{L}^{-1}$, ambos sem carvão ativado, em substrato do tipo vermiculita, apresentaram 95,0\% de sobrevivência, enquanto com carvão ativado, destacaram-se os meios que continham BAPxIAA $(0,1 \times 0,2$ e 0,5×0,5 mg. $\mathrm{L}^{-1}$ ), com 100,0 e 90,0\% de sucessos, respectivamente. Os "plantlets" originados em meios que continham carvão ativado apresentaram enraizamento mais consistente, pois mesmo em substrato do tipo vermiculita + Plantmax apresentaram boa performance, variando de 68,42 a $84,21 \%$ para as combinações de BAPxIAA: 0,1×0,2, $0,5 \times 0,0,0,5 \times 0,1$ e $0,5 \times 0,2 \mathrm{mg} \cdot \mathrm{L}^{-1}$ (Tabela 37 ).

Tabela 37. Aclimatação de brotos enraizados originados de diferentes meios de cultura em substrato de vermiculita ou vermiculita + Plantmax, 21 dias após transplantio.

\begin{tabular}{|c|c|c|c|c|c|c|c|c|c|}
\hline \multirow{2}{*}{\multicolumn{2}{|c|}{$\left(\mathrm{mg} \cdot \mathrm{L}^{-1}\right)$}} & \multicolumn{4}{|c|}{ Sem carvão } & \multicolumn{4}{|c|}{ Com carvão $(0,2 \%)$} \\
\hline & & \multicolumn{2}{|c|}{ Vermiculita } & \multicolumn{2}{|c|}{ Vermic.+Plantmax } & \multicolumn{2}{|c|}{ Vermiculita } & \multicolumn{2}{|c|}{ Vermic.+Plantmax } \\
\hline BAP & IAA & vivo/N $\mathrm{N}^{1}$ & $\%$ & Vivo/N' & $\%$ & vivo/N & $\%$ & Vivo/N' & $\%$ \\
\hline 0,1 & 0,0 & $19 / 20$ & 95,0 & $15 / 20$ & 75,0 & $11 / 21$ & 52,4 & $0 / 20$ & 0,00 \\
\hline 0,1 & 0,2 & $15 / 19$ & 78,9 & $3 / 20$ & 15,0 & $20 / 20$ & 100,0 & $13 / 19$ & 68,42 \\
\hline 0,5 & 0,0 & $19 / 24$ & 79,2 & 7/24 & 29,2 & $12 / 18$ & 66,7 & $15 / 18$ & 83,3 \\
\hline 0,5 & 0,1 & $11 / 19$ & 57,9 & $10 / 19$ & 52,6 & $12 / 15$ & 80,00 & $12 / 15$ & 80,0 \\
\hline 0,5 & 0,2 & 19/20 & 95,0 & $2 / 19$ & 10,5 & $14 / 20$ & 70,0 & $16 / 19$ & 84,21 \\
\hline 0,5 & 0,5 & $12 / 20$ & 60,0 & $7 / 20$ & 35,0 & $18 / 19$ & 90,0 & $8 / 20$ & 40,0 \\
\hline \multicolumn{2}{|c|}{ Média } & & 77,87 & & 36,07 & & 76,99 & & 57,66 \\
\hline
\end{tabular}

A utilização de carvão ativado favoreceu a adaptação dos "plantlets", sendo melhor em vermiculita com diferença significativa ao nível de 1,0\% de probabilidade, 
enquanto a diferença entre aqueles provenientes de meio de cultura sem carvão ativado foi, ainda, mais significativa, a $0,1 \%$ de probabilidade, também favorável ao substrato do tipo vermiculita (Tabela 38).

Tabela 38. Teste qui-quadrado para comparação entre a aclimatação de "plantlets" provenientes e meios de cultura com e sem carvão ativado suplementado com diferentes combinações de BAPxIAA, em substrato do tipo vermiculita e vermiculita + Plantmax.

\begin{tabular}{|c|c|c|c|c|c|c|}
\hline \multirow[b]{2}{*}{ Substrato } & \multicolumn{3}{|c|}{ Sem carvão } & \multicolumn{3}{|c|}{ Com carvão } \\
\hline & Vivo & Morto & Total & Vivo & Morto & Total \\
\hline Vermiculita & 95 & 27 & 122 & 87 & 26 & 113 \\
\hline Verm.+Plantmax & 44 & 78 & 122 & 64 & 47 & 111 \\
\hline \multirow[t]{2}{*}{ Total } & 139 & 105 & 244 & 151 & 73 & 224 \\
\hline & \multicolumn{3}{|c|}{$\chi^{2}=43,48^{\star \star *} ;$ g.I. $=1$} & \multicolumn{3}{|c|}{$9,53^{\star \star}, g . I .=1$} \\
\hline
\end{tabular}

Considerando apenas as diferentes combinações de BAPxIAA, a diferença de aclimatação dos "plantlets" não foi significativa, cuja percentagem variou de $55,56 \%$ a $66,18 \%$, para os tratamentos com $0,1 \times 0,0$ e $0,5 \times 0,1 \mathrm{mg} \cdot \mathrm{L}^{-1}$, respectivamente (Tabela 39).

Tabela 39. Teste qui-quadrado para comparação quanto a aclimatação dos "planlets" provenientes de meios de cultura com diferentes combinações de BAPXIAA.

\begin{tabular}{|c|c|c|c|c|c|}
\hline \multicolumn{2}{|c|}{$\left(\mathrm{mg} \cdot \mathrm{L}^{-1}\right)$} & \multicolumn{4}{|c|}{ "Plantlets" } \\
\hline BAP & IAA & Vivo & Morto & Total & Aclimatação (\%) \\
\hline 0,1 & 0,0 & 45 & 36 & 81 & 55,56 \\
\hline 0,1 & 0,2 & 51 & 27 & 78 & 65,38 \\
\hline 0,5 & 0,0 & 53 & 31 & 84 & 63,10 \\
\hline 0,5 & 0,1 & 45 & 23 & 68 & 66,18 \\
\hline 0,5 & 0,2 & 51 & 27 & 78 & 65,38 \\
\hline 0,5 & 0,5 & 45 & 34 & 79 & 56,96 \\
\hline Total & & 290 & 178 & 468 & 61,97 \\
\hline & & & ; g.I & & \\
\hline
\end{tabular}


Outrossim, os "plantlets" originados em meios de cultura com a metade ou completa concentração de sais, suplementados com NAA ou IBA, apresentaram, também, melhor adaptação em substrato do tipo vermiculita. Por outro lado, aclimataram-se bem em substrato vermiculita + Plantmax, aqueles oriundos de meio de cultura MS suplementado tanto com NAA quanto com IBA àconcentração de 0,1 e 0,5 $\mu \mathrm{M}$.

Entretanto, os "plantlets" originados em meio de cultura, com metade da concentração de sais suplementado com IBA, apresentaram melhor adaptação em substrato vermiculita em média de $89,90 \%$ contra média de $53,85 \%$ em substrato do tipo vermiculita e Plantmax, sendo semelhante para aqueles provenientes de completa concentração de sais de MS. Provenientes de NAA, as percentagens de adaptação foram muito semelhantes para os dois tipos de substratos, tanto originados em 1/2MS quanto em MS, porém melhores resultados foram obtidos com aqueles provenientes de meio de cultura com sais de MS completo em ambos os substratos (Tabela 40).

Tabela 40. Aclimatação de brotos enraizados originados de diferentes meios de cultura em substrato de vermiculita ou vermiculita + Plantmax, 40 dias após transplantio.

\begin{tabular}{|c|c|c|c|c|c|c|c|c|c|}
\hline \multirow[t]{3}{*}{ R. C. } & \multirow[t]{3}{*}{$\mu \mathrm{M}$} & \multicolumn{4}{|c|}{$1 / 2 \mathrm{MS}$} & \multicolumn{4}{|c|}{ MS } \\
\hline & & \multicolumn{2}{|c|}{ Vermiculita } & \multicolumn{2}{|c|}{ Verm.:Plantmax } & \multicolumn{2}{|c|}{ Vermiculita } & \multicolumn{2}{|c|}{$\begin{array}{c}\text { Verm.:Plantma } \\
\mathrm{x}\end{array}$} \\
\hline & & vivo/ $N^{\prime}$ & $\%$ & vivo/N' & $\%$ & vivo/N $N^{\top}$ & $\%$ & vivo/N' & $\%$ \\
\hline \multirow{6}{*}{ NAA } & 0,0 & $5 / 22$ & 23,0 & $10 / 22$ & 45,0 & - & - & - & - \\
\hline & 0,1 & $8 / 21$ & 38,0 & $7 / 21$ & 33,0 & $24 / 25$ & 96,0 & $25 / 25$ & 100,0 \\
\hline & 0,5 & $2 / 20$ & 10,0 & $0 / 20$ & 00,0 & $13 / 25$ & 52,0 & $18 / 25$ & 72,0 \\
\hline & 1,0 & $0 / 20$ & 00,0 & $1 / 20$ & 05,0 & $1 / 25$ & 4,0 & $3 / 25$ & 12,0 \\
\hline & 2,5 & $0 / 17$ & 00,0 & $0 / 17$ & 00,0 & $4 / 21$ & 19,0 & - & - \\
\hline & 5,0 & $0 / 5$ & 00,0 & $0 / 6$ & 00,0 & - & - & $0 / 21$ & 00,0 \\
\hline \multirow[t]{2}{*}{ Média } & & & 14,29 & & 16,98 & & 43,75 & & 47,92 \\
\hline & 0,1 & $19 / 19$ & 100,0 & $10 / 19$ & 53,0 & $16 / 22$ & 73,0 & $13 / 23$ & 56,0 \\
\hline \multirow[t]{4}{*}{ IBA } & 0,5 & $21 / 22$ & 95,0 & $14 / 23$ & 61,0 & $13 / 17$ & 76,0 & $10 / 18$ & 55,0 \\
\hline & 1,0 & $23 / 23$ & 100,0 & $14 / 27$ & 52,0 & $10 / 17$ & 59,0 & $6 / 18$ & 33,0 \\
\hline & 2,5 & $16 / 17$ & 94,0 & $5 / 17$ & 29,0 & $18 / 24$ & 75,0 & $8 / 24$ & 33,0 \\
\hline & 5,0 & $10 / 18$ & 55,0 & $13 / 18$ & 72,0 & $2 / 25$ & 8,0 & $0 / 25$ & 00,0 \\
\hline Média & & & 89,90 & & 53,85 & & 56,19 & & 34,26 \\
\hline
\end{tabular}


Os testes qui-quadrado confirmaram comportamento semelhante entre os "plantlets" provenientes de 1/2MS e MS, mas, em relação ao regulador de crescimento, o uso de IBA favoreceu significativamente a sobrevivência dos "plantlets", mesmo considerando somente os níveis mais eficientes, 0,1 a $2,5 \mu \mathrm{M}$, principalmente com $1 / 2$ MS em substrato do tipo vermiculita (Tabelas 41, 42 e 43).

Tabela 41. Teste qui-quadrado quanto a aclimatação de "plantlets" em dois tipos de substrato provenientes de meios de cultura com metade ou completa concentração de MS suplementado com NAA.

\begin{tabular}{lccc|ccc}
\hline Substrato & \multicolumn{3}{c}{ 1/AS } & \multicolumn{3}{c}{ MS } \\
\cline { 2 - 7 } & Vivo & morto & Total & Vivo & morto & Total \\
\hline Vermiculita & 15 & 90 & 105 & 42 & 54 & 96 \\
Verm.+Plantmax & 18 & 88 & 106 & 46 & 50 & 96 \\
Total & 33 & 178 & 211 & 88 & 104 & 192 \\
& & & & $0,34^{\text {NS. }} ;$ g.l. $=1$ & \\
& \multicolumn{2}{c}{$\chi^{2}=0,29^{\text {NS }} ;$ g.l. $=1$} & & &
\end{tabular}

${ }^{\mathrm{TS}}$ Não significativo

Tabela 42. Teste qui-quadrado quanto a aclimatação de "plantlets" em dois tipos de substrato provenientes de meios de cultura com metade ou completa concentração de MS suplementado com IBA.

\begin{tabular}{lccc|ccc}
\hline Substrato & \multicolumn{3}{c}{$1 /$ MS } & \multicolumn{3}{c}{ MS } \\
\cline { 2 - 7 } & Vivo & morto & Total & Vivo & morto & Total \\
\hline Vermiculita & 89 & 10 & 99 & 59 & 46 & 105 \\
Verm.+Plantmax & 56 & 48 & 104 & 37 & 71 & 108 \\
Total & 145 & 58 & 203 & 96 & 117 & 213 \\
& \multicolumn{2}{c}{$\chi^{2}=32,32^{* *} ;$ g.l. $=1$} & & $10,35^{* *} ;$ g.l. $=1$ \\
\hline
\end{tabular}

${ }^{\star \star \star},{ }^{\star \star}$ Significativo ao nível de $0,1 \%$ e $1 \%$ de probabilidade, respectivamente 
Tabela 43. Teste qui-quadrado quanto a aclimatação de "plantlets" sob a ação de meios de cultura com metade ou completa concentração de MS e de NAA e IBA às concentrações de 0,1 a 2,5 $\mu \mathrm{M}$.

\begin{tabular}{|c|c|c|c|c|c|c|c|}
\hline \multirow{2}{*}{ Trat. } & \multicolumn{3}{|c|}{ "Plantlets" } & \multirow{2}{*}{ Trat. } & \multicolumn{3}{|c|}{ "Plantlets" } \\
\hline & Vivo & Morto & Total & & Vivo & Morto & Total \\
\hline $1 / \mathrm{dMS}$ & 178 & 236 & 414 & NAA & 106 & 221 & 327 \\
\hline MS & 184 & 221 & 405 & IBA & 216 & 114 & 330 \\
\hline Total & 362 & 457 & 819 & & 322 & 335 & 657 \\
\hline \multicolumn{5}{|c|}{$\chi^{2}=0,433^{\text {NS }} ;$ g.I. $=1$} & \multicolumn{3}{|c|}{$71,74^{* * *} ;$ g.I. $=1$} \\
\hline
\end{tabular}

"NSÁO significativo

${ }^{* \star *}$ Significativo ao nível de $0,1 \%$

O nível mais apropriado para adaptação dos "plantlets" com NAA, foi de $0,1 \mu \mathrm{M}$, com média de $69,57 \%$ de sobrevivência, cuja diferença foi significativa entre todos os níveis à probabilidade de $0,1 \%$, enquanto para IBA não houve diferença significativa entre os níveis, pois se observaram médias entre 57,31 a $72,50 \%$, sendo as melhores performances às concentrações de 0,1 e 0,5 $\mu \mathrm{M}$, com médias de 69,88 e $72,50 \%$, respectivamente (Tabela 44).

Tabela 44. Teste qui-quadrado quanto a aclimatação de "plantlets" provenientes de meio básico de cultura MS com NAA ou IBA a diferentes concentrações.

\begin{tabular}{|c|c|c|c|c|c|c|c|c|}
\hline \multirow[b]{2}{*}{$(\mu \mathrm{M})$} & \multicolumn{4}{|c|}{ NAA } & \multicolumn{4}{|c|}{ IBA } \\
\hline & Vivo & Morto & Total & Aclim. (\%) & Vivo & Morto & Total & Aclim. (\%) \\
\hline 0,0 & 15 & 29 & 44 & 34,09 & - & - & - & - \\
\hline 0,1 & 64 & 28 & 92 & 69,57 & 58 & 25 & 83 & 69,88 \\
\hline 0,5 & 33 & 57 & 90 & 36,67 & 58 & 22 & 80 & 72,50 \\
\hline 1,0 & 5 & 85 & 90 & 5,56 & 53 & 32 & 85 & 62,35 \\
\hline 2,5 & 4 & 51 & 55 & 7,27 & 47 & 35 & 82 & 57,31 \\
\hline 5,0 & - & - & - & - & & - & - & \\
\hline \multirow[t]{2}{*}{ Total } & 121 & 250 & 371 & 32,61 & 216 & 114 & 330 & 65,45 \\
\hline & \multicolumn{4}{|c|}{$\chi^{2}=103,73^{* * *} ;$ g.l. $=4$} & \multicolumn{4}{|c|}{$\chi^{2}=5,24^{\mathrm{NS}} ;$ g.I. $=3$} \\
\hline
\end{tabular}

${ }^{* * *}$ Significativo ao nível de $0,1 \%$ de probabilidade

${ }^{\mathrm{NS}}$ Não significativo 
Os "plantlets" originados de gemas apresentaram maior sobrevivência quanto a aclimatação quando provenientes de IBA, principalmente com metade da concentração de sais de MS, mas se mostraram eficientes, os originados do mesmo meio de multiplicação de gemas com adição de carvão ativado a 0,2\%.

O substrato do tipo vermiculita foi mais eficiente ao processo de aclimatação dos "plantlets" (Figura 16a), pois apresentou grande capacidade de retenção de umidade sem acúmulo de água, enquanto o substrato do tipo vermiculita + "plantmax" apresentou acúmulo de água, prejudicial à adaptação inicial, uma vez que o mais importante nesta fase é a umidade relativa do ar e não o acúmulo de água nas raízes. Os sobreviventes após a fase de aclimatação foram transferidos para sacos pretos de polietileno com solo e mantidos em telado ou casa-de-vegetação para crescimento e formação de mudas (Figura 16b e 16c).

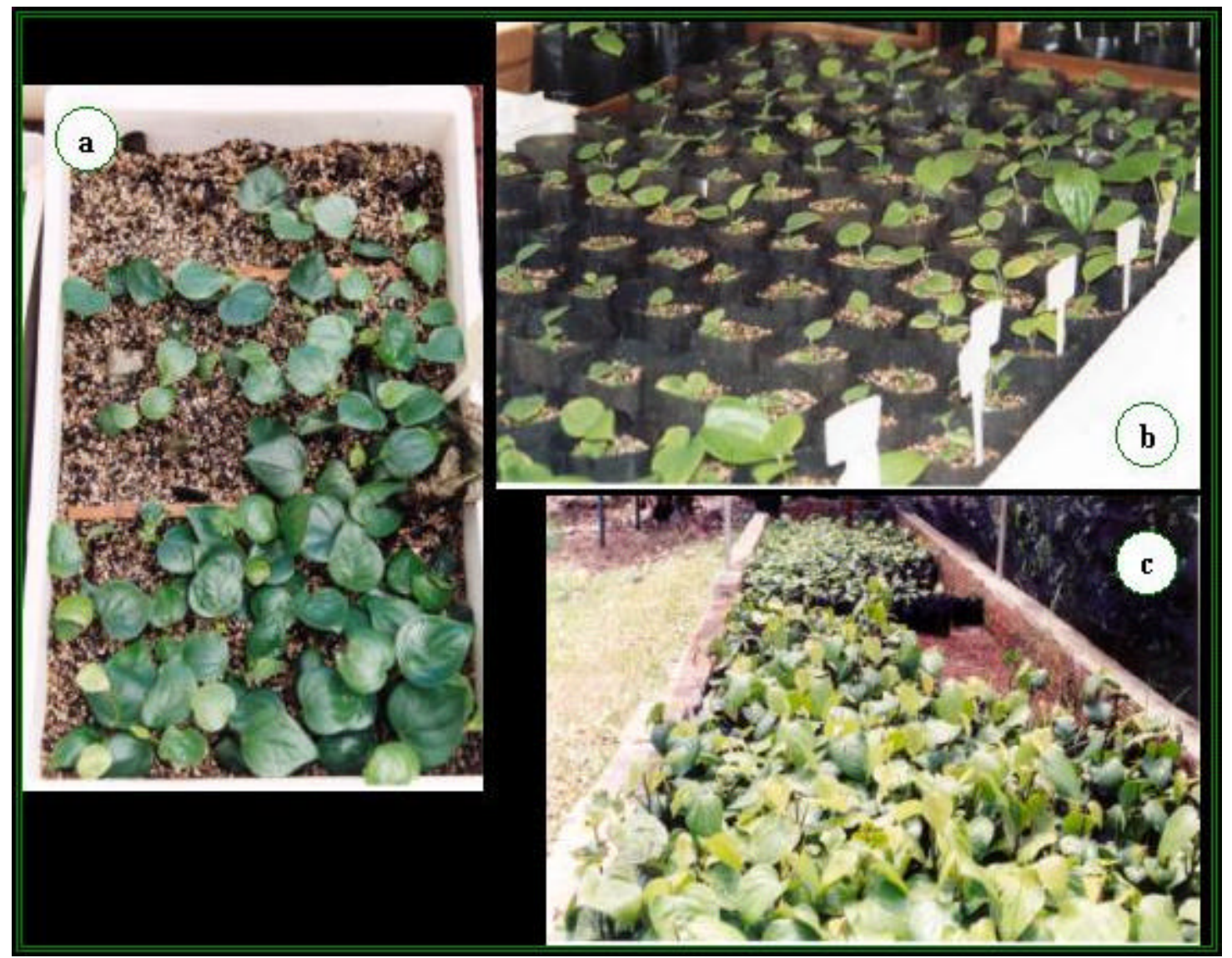

Figura 16 - Aclimatação e formação de mudas a partir de "plantlets".

a) Aclimatação em substrato do tipo vermiculita

b) Transferência para sacos de polietileno preto para desenvolvimento das plantas

c) formação de mudas 


\subsubsection{Assepsia de explantes provenientes de plantas propagadas via estacas}

Os testes exploratórios iniciais de assepsia de explantes a partir de mudas, propagadas via estacas em casa-de-vegetação, através de utilização apenas de álcool e hipoclorito de sódio, não apresentaram sucessos, pois ocorreram contaminações por fungos e bactérias, e oxidação dos explantes, o que tornou inviáveis os explantes.

No experimento com diferentes soluções de antibiótico no meio de cultura, os antibióticos do tipo gentamicina, ampicilina e cefalexina, nas concentrações utilizadas (250, 160 e $250 \mathrm{mg} \cdot \mathrm{L}^{-1}$, respectivamente), foram ineficientes no controle de bactérias, pois em todos os tratamentos os explantes apresentaram contaminações por bactérias, que variou, aos 21 dias, de 9,88\% (gentamicina) a 18,52\% (ampicilina). Além das contaminações, foi verificada a oxidação dos explantes em todos os tratamentos, cuja variação foi de 4,94\% (sem antibiótico) a 9,88\% (gentamicina). A sobrevivência nos principais tratamentos dos explantes alcançou 4,94\%, sendo que, do total de 81 explantes testados, 13 sobreviventes foram conseguidos, equivalentes a $16,05 \%$ de eficiência (Tabela 45).

Tabela 45. Efeito de tratamento de assepsia sobre contaminação, sobrevivência e oxidação de explantes provenientes de plantas propagadas via estacas, após 21 dias de cultivo.

\begin{tabular}{lcccc}
\hline Tratamento $^{1}$ & \multicolumn{4}{c}{ Efeito } \\
\cline { 2 - 5 } & Contaminação & Sobrevivência & Oxidação & Total \\
\hline 1 & $11(13,58 \%)$ & $4(4,94 \%)$ & $4(4,94 \%)$ & $19(23,45 \%)$ \\
2 & $8(9,88 \%)$ & $4(4,94 \%)$ & $8(9,88 \%)$ & $20(24,69 \%)$ \\
3 & $11(13,58 \%)$ & $4(4,94 \%)$ & $6(7,41 \%)$ & $21(25,93 \%)$ \\
4 & $15(18,52 \%)$ & $1(1,23 \%)$ & $5(6,17 \%)$ & $21(25,93 \%)$ \\
& & & & \\
Total & $45(55,56 \%)$ & $13(16,05 \%)$ & $23(28,40 \%)$ & $81(100,00 \%)$ \\
\hline
\end{tabular}

Tratamentos: 1 - sem antibiótico; 2 - com gentamicina (250 mg. $\left.\mathrm{L}^{-1}\right) ; 3$ - com cefalexina (250 $\left.\mathrm{mg} \cdot \mathrm{L}^{-1}\right)$; e 4 - com ampicilina $\left(160 \mathrm{mg} \cdot \mathrm{L}^{-1}\right)$

O teste qui-quadrado indicou que as diferenças entre os tratamentos foram significativas aos 7 dias, mas não aos 21 dias quanto ao número de gemas sobreviventes e não sobreviventes (Tabela 46). Considerando que o tratamento sem antibiótico no meio de cultura apresentou performance semelhante aos demais, acredita-se que o tratamento asséptico inicial, com detergente neutro, benlate $(0,2 \%)$, 
álcool $70 \%$ ( $\mathrm{v} / \mathrm{v})$ e hipoclorito de sódio $1 \%$ e água esterilizada, teve um papel importante no processo de assepsia dos explantes.

Tabela 46. Efeito de tratamentos de assepsia na sobrevivência de gemas originadas de plantas propagadas por estacas sob casa-de-vegetação.

\begin{tabular}{lcc|ccc}
\hline \multirow{2}{*}{ Tratamento } & \multicolumn{2}{c}{7 dias } & \multicolumn{2}{c}{21 dias } & \multirow{2}{*}{ Total } \\
\cline { 2 - 5 } & Sobrev. & Mortal. & Sobrev. & Mortal. & \\
\hline Normal & 8 & 11 & 4 & 15 & 19 \\
Gentamicina & 15 & 5 & 4 & 16 & 20 \\
Cefalexina & 15 & 6 & 4 & 17 & 21 \\
Ampicilina & 9 & 12 & 1 & 20 & 21 \\
Total & 47 & 34 & 13 & 68 & 13 \\
& & & & & \\
& $\chi^{2}=7,88^{*} ;$ g.l. $=3$ & $\chi^{2}=7,39^{\text {NS }} ;$ g.l. $=3$ & \\
\hline
\end{tabular}

*significativo ao nível de $5 \%$ de probabilidade

${ }^{\mathrm{NS}}$ Não significativo

Ademais, os explantes assépticos foram aptos à diferenciação de gemas, pois as gemas sobreviventes diferenciaram e apresentaram performances semelhantes æ̀ gemas obtidas a partir de plântulas in vitro (Figura 17a e 17b). Considerou-se que as condições preestabelecidas para o processo de micropropagação foram eficientes, também, a partir de gemas de plantas propagadas vegetativamente, haja vista diferenciação de novas gemas terem sido desencadeadas. Portanto, as condições in vitro para a clonagem de plantas de pimenta-do-reino foram estabelecidas.

Problemas semelhantes foram observados por Philip et al. (1992), cuja eficiência do melhor tratamento com cloreto de mercúrio $\left(0,1 \% \mathrm{HgCl}_{2}\right)$ e reesterilização semanal, foi de $20 \%$ porém, afetou a viabilidade das culturas. Então, há necessidade de um equilíbrio entre a eficiência da assepsia e a viabilidade dos explantes. O grande problema é a presença de bactérias endógenas, difíceis de serem desinfetadas, sendo o mais conveniente o emprego de bacteriostático, que permita 0 controle delas sem afetar as respostas dos explantes in vitro. 


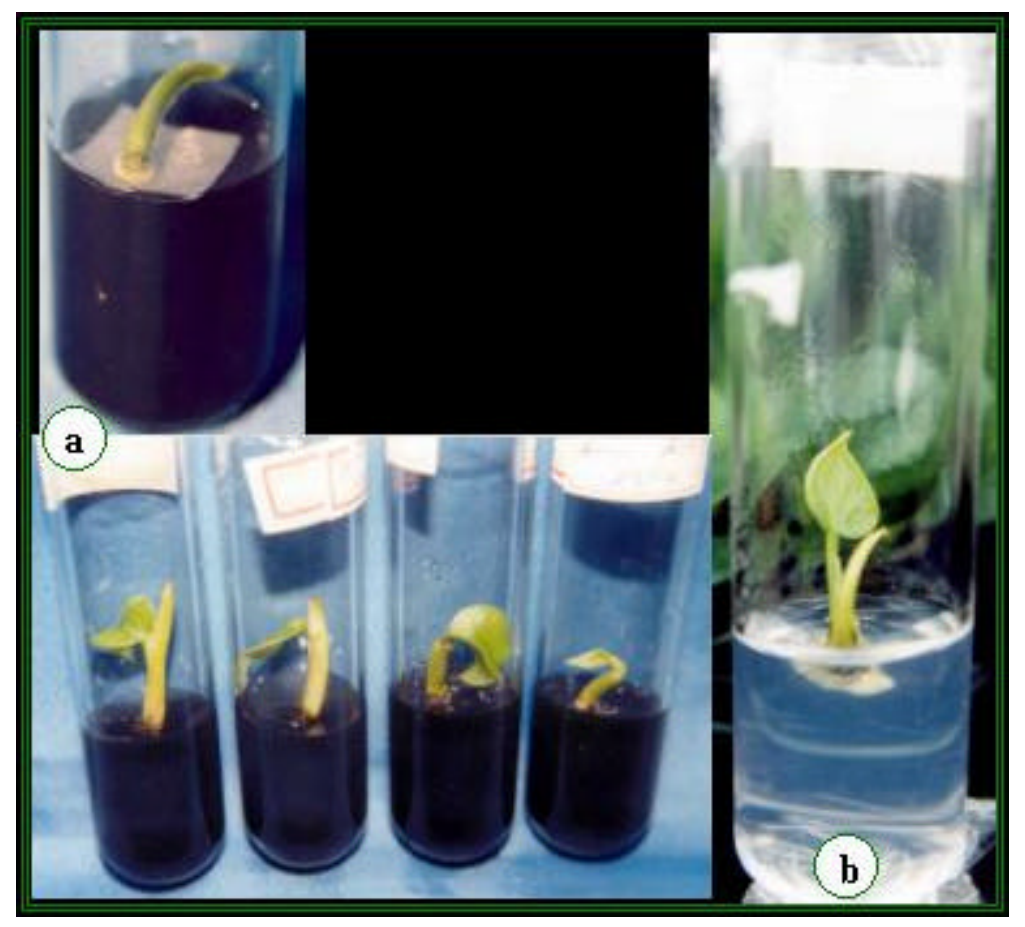

Figura 17 - Assepsia de explantes a partir de mudas propagadas via estacas.

a) Gemas assépticas em meio básico de cultura MS, BAP 0,1 mg. $\mathrm{L}^{-1}$ e IAA 0,2 mg. $\mathrm{L}^{-1}$ e com carvão ativado após 21 dias de cultivo

b) Em fase de diferenciação de gemas em meio de cultura MS com BAP $0,5 \mathrm{mg} \cdot \mathrm{L}^{-1} \mathrm{e}$ IAA 0,2 mg. $\mathrm{L}^{-1}$

\subsubsection{Multiplicação de plantas $\mathrm{V}_{5}$}

Obteve-se sucesso na multiplicação de gemas, com diferença significativa quanto a proliferação de gemas entre as linhagens em meio básico de cultura MS suplementado com BAP a 0,5 e IAA a 0,2 mg. $\mathrm{L}^{-1}$, após 6 semanas de cultivo, cuja média variou entre duas e três gemas por explante (Tabela 47).

Tabela 47. Análise da variância de proliferação de gemas a partir do cultivo in vitro de explantes das diferentes linhagens $V_{5}$ em meio básico de cultura MS suplementado com BAP a 0,5 e IAA a 0,2 mg. $\mathrm{L}^{-1}$, após 6 semanas de cultivo.

\begin{tabular}{lccc}
\hline C. de Variação & G.L. & Q.M. & F \\
\hline (Tratamentos) & 11 & 0,2610 & 2.24 * \\
Resíduos & 24 & 0,1168 & \\
\hline 'Média geral = 2,46; desvio padrão $=0,34 ;$ e CV $=13,90 \%$ & & \\
*Significativo ao nível de 1\% de probabilidade & &
\end{tabular}


As diferenças entre as médias foram significativas entre as linhagens $V_{5}$, menor que aquelas normalmente obtidas com a cultivar tradicional (acima de três gemas por explante), nas mesmas condições de cultivo. A linhagem de melhor performance foi $\mathrm{C} 123$ (3,02 gemas por explante) e a de pior (2,04 gemas por explante) foi a linhagem C45 (Tabela 48).

Tabela 48. Teste Duncan para comparação de médias de proliferação de gemas a partir de explantes de 12 linhagens $V_{5}$ em meio básico de cultura MS suplementado com BAP e IAA com 0,5 e 0,2 mg. $\mathrm{L}^{-1}$, respectivamente.

\begin{tabular}{ll}
\hline \multicolumn{1}{c}{ Linhagem } & \multicolumn{1}{c}{ Média $^{1}$} \\
\hline $\mathrm{C} 26$ & $2.34 \mathbf{b c}$ \\
$\mathrm{C} 27$ & $2.60 \mathbf{a b c}$ \\
$\mathrm{C} 45$ & $2.04 \mathbf{c}$ \\
$\mathrm{C} 70$ & $2.45 \mathbf{a b c}$ \\
$\mathrm{C} 121$ & $2.23 \mathbf{b c}$ \\
$\mathrm{C} 123$ & $3.02 \mathbf{a}$ \\
$\mathrm{C} 132$ & $2.37 \mathbf{a b c}$ \\
$\mathrm{N} 134$ & $2.07 \mathbf{c}$ \\
$\mathrm{C} 137$ & $2.58 \mathbf{a b c}$ \\
$\mathrm{C} 166$ & $2.59 \mathbf{a b c}$ \\
$\mathrm{C} 170$ & $2.34 \mathbf{b c}$ \\
$\mathrm{CT}$ & $2.88 \mathbf{a b}$ \\
$\mathrm{Cé}$ & 2,46 \\
\hline
\end{tabular}

Médias seguidas da mesma letra não diferem entre si

Parte dos brotos de todas as linhagens foi enraizada em meio básico de cultura MS suplementado com NAA $\left(0,1 \mathrm{mg}^{\mathrm{L}} \mathrm{L}^{-1}\right)$ e aclimatizados para formação de mudas (Figura 18a-e), enquanto outra parte está sendo mantida em processo de multiplicação para, posteriormente, ser submetida à seleção in vitro contra o fungo, através de filtrado da cultura do fungo como agente seletivo, clonagem subseqüente visando testes em casa-de-vegetação e campo, e incorporação em programa de melhoramento genético da cultura. 


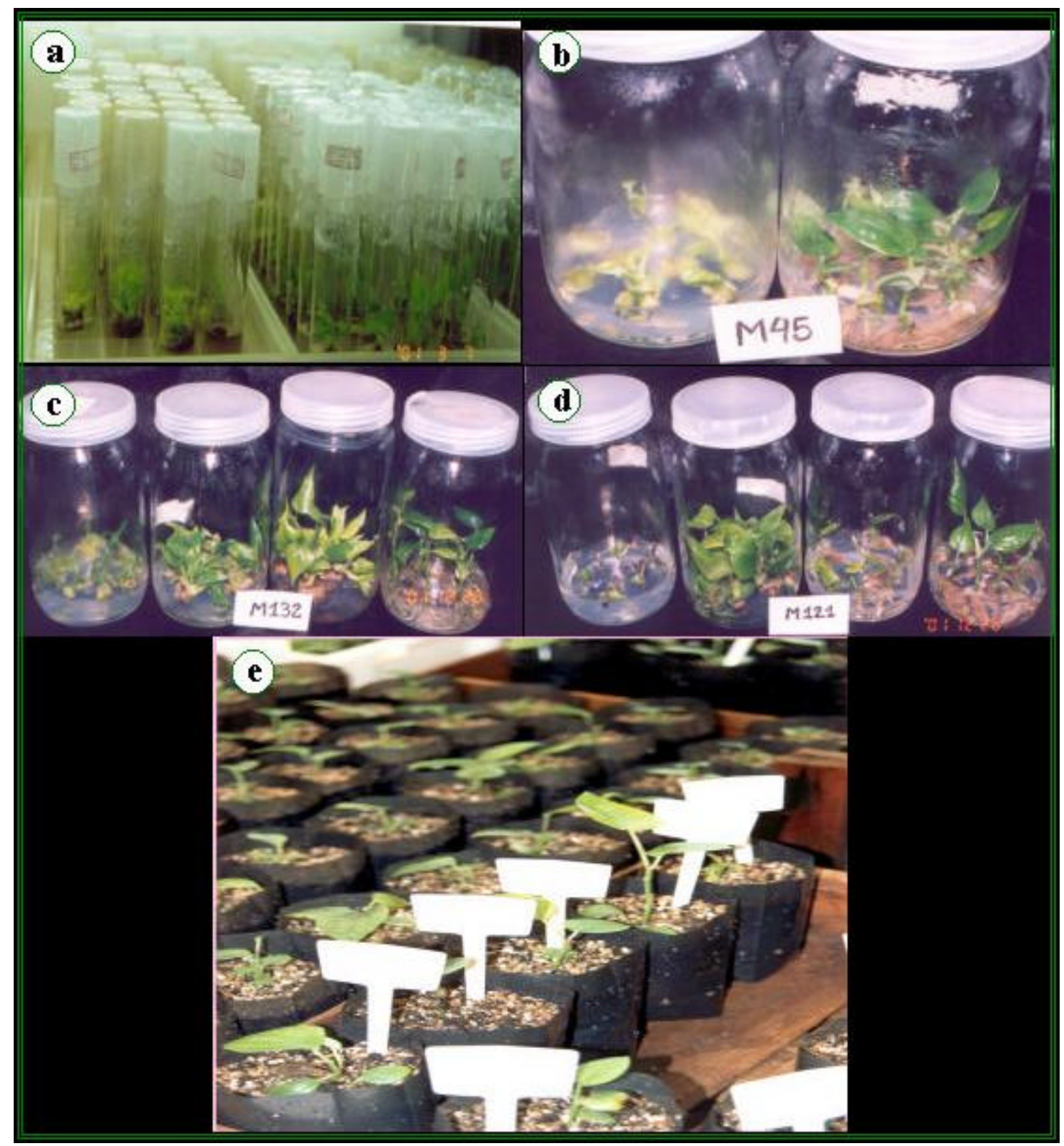

Figura 18 - Micropropagação de plantas $\mathrm{V}_{5}$.

a) Fase de estabelecimento e multiplicação de gemas

b) Proliferação de gemas e enraizamento de brotos da linhagem C45

c) Idem para a linhagem C132

d) Idem para a linhagem C121

e) Fase de formação de mudas 


\subsubsection{Indução de calos}

No primeiro experimento, observou-se diferenças significativas nos tratamentos para indução de calos nos explantes quanto as diferentes concentrações de dicamba e BAP, e nas inter-relações entre dicamba x BAP e entre os três fatores. Por outro lado, a ação de TDZ não apresentou diferença para indução de calos nas diferentes concentrações $(0,1$ a $1,0 \mu \mathrm{M})$, ao contrário do efeito de fotoperíodo (escuro ou luz) e BAP (0 e $1 \mu \mathrm{M})$ e dos três fatores que interagiram significativamente entre si (Tabela 49).

Tabela 49. Análise da variância em fatorial $2 \times 3 \times 2$ quanto a indução de calos em segmentos de entrenós cultivados em meio básico $\mathrm{SH}$ suplementado com dicamba $(5,10$ e $20 \mu \mathrm{M})$ ou TDZ $(0,1,0,5$ e 1,0 $\mu \mathrm{M})$ em combinação com BAP $(0$ e 1,0 $\mu \mathrm{M})$, após 30 dias de cultivo.

\begin{tabular}{|c|c|c|c|c|c|}
\hline \multirow[t]{2}{*}{ Fonte de variação } & \multirow[t]{2}{*}{ G. L. } & \multicolumn{2}{|c|}{ Q. M. } & \multicolumn{2}{|c|}{$\mathrm{F}$} \\
\hline & & Dicamba $^{1}$ & $\mathrm{TDZ}^{2}$ & Dicamba & TDZ \\
\hline Fotoperíodo $(\mathrm{A})$ & 1 & 0,718 & 0,206 & 16,16 & 5,05 \\
\hline Dicamba ou TDZ (B) & 2 & 3,587 & 0,051 & $80,74^{\star \star}$ & $1,24 \mathrm{~ns}$ \\
\hline $\mathrm{BAP}(\mathrm{C})$ & 1 & 0,462 & 0,439 & $10,39^{* *}$ & $10,77^{\star *}$ \\
\hline$A \times B$ & 2 & 0,062 & 0,427 & $1,39 \mathrm{~ns}$ & $10,47^{\star \star}$ \\
\hline$A \times C$ & 1 & 0,053 & 0,166 & $1,20 \mathrm{~ns}$ & $4,07^{\star}$ \\
\hline $\mathrm{BxC}$ & 2 & 0,302 & 0,223 & $6,79^{* *}$ & $5,46^{*}$ \\
\hline $\mathrm{A} \times \mathrm{B} \times \mathrm{C}$ & 2 & 0,325 & 0,443 & $7,31^{\star \star}$ & $10,86^{\star \star}$ \\
\hline Tratamentos & 11 & 9,784 & 0,281 & - & - \\
\hline Resíduos & $47^{3} / 40^{4}$ & 2,088 & 0,041 & - & - \\
\hline $\begin{array}{l}{ }^{2} \text { Média geral=1,4928; } \\
{ }^{2} \text { Média geral=1,1613; } \\
* \star \star * \\
* \text { Significativo ao nív } \\
{ }^{3} \text { Graus de liberdade } p \\
{ }^{4} \text { Graus de liberdade }\end{array}$ & $\begin{array}{l}\text { padrão= } \\
\text { padrão= } \\
\% \text { e } 5 \% \\
\text { xperime } \\
\text { experime }\end{array}$ & $\begin{array}{l}8 ; C V=14 \\
\text { 9; CV=17 } \\
\text { babilidade } \\
\text { m dicamb } \\
\text { om TDZ }\end{array}$ & ctiva & & \\
\hline
\end{tabular}

A indução de calos foi mais favorável em dicamba do que em TDZ e, enquanto a condição de escuro favoreceu a ação de formação de calos na presença de dicamba, o fotoperíodo de $16 \mathrm{~h}$ de luz favoreceu a ação de TDZ, e ambos foram mais eficientes na presença de BAP a 1,0 $\mu \mathrm{M}$ (Tabelas 50 e 51). Dentre os tratamentos, destacou-se a presença de dicamba a $10 \mu \mathrm{M}\left(2,21 \mathrm{mg} \cdot \mathrm{L}^{-1}\right)$, principalmente sob condição de escuro. Resultados eficientes foram conseguidos com bananeira na

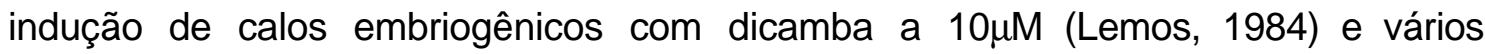


sucessos em diferentes plantas foram obtidos com TDZ (Xie \& Hong, 2001; Thomas et al., 2000; Murch et al., 2000).

Tabela 50. Indução de calos em meio básico SH suplementado com diferentes combinações de dicambaxBAP sob condições de luz e escuro, após 30 dias de cultivo.

\begin{tabular}{|c|c|c|c|c|c|c|c|c|c|c|c|}
\hline \multirow{3}{*}{$\begin{array}{c}\text { Dic. }^{1} \\
(\mathrm{~B}) \\
(\mu \mathrm{M})\end{array}$} & \multicolumn{3}{|c|}{$\overline{\text { Escuro }^{3}\left(A_{1}\right)}$} & \multicolumn{3}{|c|}{$\operatorname{Luz}^{3}\left(\mathrm{~A}_{2}\right)$} & \multirow{3}{*}{$\begin{array}{c}\text { Média }^{2} \\
\text { (B) }\end{array}$} & \multicolumn{4}{|c|}{ Fotoperíodo } \\
\hline & \multicolumn{3}{|c|}{$\operatorname{BAP}(\mu \mathrm{M})^{4}-(\mathrm{C})$} & \multicolumn{3}{|c|}{$\operatorname{BAP}(\mu \mathrm{M})^{4}-(\mathrm{C})$} & & \multicolumn{4}{|c|}{$\operatorname{BAP}(\mu \mathrm{M})$} \\
\hline & 0 & 1 & $\mathrm{BxA}_{1}{ }^{5}$ & 0 & 1 & $\mathrm{BxA}_{2}^{5}$ & & \multicolumn{2}{|c|}{0} & \multicolumn{2}{|r|}{1} \\
\hline 5 & 0,16 & 2,00 & $\mathrm{NS}^{6}$ & $\overline{0,16}$ & 0,28 & NS & $0,54 \mathbf{c}$ & $0,16 \mathrm{c}$ & $\mathrm{B}$ & $A$ & $1,02 \mathbf{b}$ \\
\hline 10 & 3,38 & 3,00 & NS & 2,76 & 2,60 & NS & $2,92 \mathbf{a}$ & $3,06 \mathbf{a}$ & & A & $2,79 \mathbf{a}$ \\
\hline 20 & 2,33 & 2,48 & NS & 1,37 & 2,38 & NS & $2,12 \mathbf{b}$ & $1,83 \mathbf{b}$ & $A$ & A & $2,43 a$ \\
\hline Média $^{2}$ & & 2,08 & & & 1,42 & & & $1,48 \mathrm{~B}$ & & & $2,01 \mathrm{~A}$ \\
\hline \multicolumn{12}{|c|}{$\begin{array}{l}{ }^{1} \text { Fator } B \text {, dicamba constituído de três níveis: } 1-5 \mu \mathrm{M}\left(\mathrm{B}_{1}\right) ; 2-10 \mu \mathrm{M}\left(\mathrm{B}_{2}\right) \text {; e } 3-20 \mu \mathrm{M}\left(\mathrm{B}_{3}\right. \\
{ }^{2} \text { Médias seguidas pela mesma letra não diferem entre si. Letras minúsculas: col } \\
\text { vertical; letras maiúsculas: comparação horizontal } \\
{ }^{3} \text { Fator } A \text {, fotoperíodo constituído de dois níveis: } 1 \text { - Escuro }\left(A_{1}\right) ; 2-\operatorname{Luz}\left(A_{2}\right) \\
{ }^{4} \text { Fator C, BAP }(\mu \mathrm{M}) \text { constituído de dois níveis: } 1-0 \mu \mathrm{M}\left(\mathrm{BAP}_{0}\right) ; 2-1,0 \mu \mathrm{M}\left(\mathrm{BAP}_{1}\right) \\
{ }^{5} \text { Interação entre diferentes níveis de dicamba em condições de escuro }\left(\mathrm{A}_{1}\right) \text { e de luz }\left(\mathrm{A}_{2}\right) \\
\text { NS - não significativo }\end{array}$} \\
\hline
\end{tabular}

Tabela 51. Indução de calos em meio básico SH suplementado com diferentes combinações de TDZxBAP sob condições de luz e escuro, após 30 dias de cultivo.

\begin{tabular}{|c|c|c|c|c|c|c|c|c|}
\hline \multirow{2}{*}{$\begin{array}{l}\text { TDZ } \\
(\mu \mathrm{M})\end{array}$} & \multicolumn{3}{|c|}{$\operatorname{BAP}^{1}(\mathrm{C})$} & \multicolumn{4}{|c|}{ Fotoperíodo $^{2}(\mathrm{~A})$} & \multirow{2}{*}{$\begin{array}{r}\text { Média } \\
\text { Geral }\end{array}$} \\
\hline & Escuro $\left(A_{1}\right)$ & & $\operatorname{Luz}\left(A_{2}\right)$ & $\mathrm{BAP}_{0}$ & & & $\mathrm{BAP}_{1}$ & \\
\hline 0,1 & $1,09 \mathbf{a}$ & $A \quad B$ & $0,56 \quad \mathbf{b}$ & $0,64 \mathbf{a b}$ & A & A & $1,00 \mathbf{a}$ & $0,81 \mathbf{a}$ \\
\hline 0,5 & $0,56 \mathbf{a b}$ & B A & $1,50 \mathbf{a}$ & $1,03 \mathbf{a}$ & A & A & $0,96 \mathbf{a}$ & $1,00 \mathbf{a}$ \\
\hline 1,0 & $0,50 \quad \mathbf{b}$ & B A & $1,02 \mathbf{a b}$ & $0,31 \quad \mathbf{b}$ & B & A & $1,27 \mathbf{a}$ & $0,75 \mathbf{a}$ \\
\hline Média $^{3}$ & $0,70 \mathrm{~B}$ & & $1,00 \mathrm{~A}$ & $0,64 \mathrm{~B}$ & & & $1,08 \mathrm{~A}$ & Média $^{3}$ \\
\hline BAP 0 & $0,40 \mathrm{~B}$ & & $0,92 \mathrm{~A}$ & $0,40 \mathrm{~B}$ & & & $1,06 \mathrm{~A}$ & Escuro \\
\hline BAP 1 & $1,06 \mathrm{~A}$ & & $1,09 \mathrm{~A}$ & $0,92 \mathrm{~A}$ & & & $1,09 \mathrm{~A}$ & Luz \\
\hline
\end{tabular}

${ }^{1}$ Fator $\mathrm{C}$ constituído de dois níveis: 1 - $0 \mu \mathrm{M}\left(\mathrm{BAP}_{0}\right) ; 2-1,0 \mu \mathrm{M}\left(\mathrm{BAP}_{1}\right)$

${ }^{2}$ Fator A constituído de dois níveis: 1 - Escuro; 2 - Luz

${ }^{3}$ Médias seguidas pela mesma letra não diferem entre si. Letras minúsculas: comparação vertical; letras maiúsculas: comparação horizontal

No segundo experimento, no qual testou-se dicamba a $2,5 \mathrm{mg}^{-\mathrm{L}^{-1}}(11,31 \mu \mathrm{M})$ em combinação com BAP (0 a 1,0 mg. $\left.\mathrm{L}^{-1}\right)$, observou-se respostas diferenciadas dos 
tratamentos quanto a indução de calos e ao índice de oxidação dos explantes (Tabela 52).

Tabela 52. Análise da variância de média de indução de calos e oxidação de explantes em meio básico de cultura SH suplementado com dicamba a 2,5 mg. $\mathrm{L}^{-1} \mathrm{em}$ combinação com diferentes concentrações de BAP, após 45 dias de cultivo.

\begin{tabular}{|c|c|c|c|c|c|}
\hline \multirow[t]{2}{*}{ Fonte de variação } & \multirow[t]{2}{*}{ G. L. } & \multicolumn{2}{|c|}{ Q. M. } & \multicolumn{2}{|c|}{$\mathrm{F}$} \\
\hline & & Calos & Oxidação $^{2}$ & Calos $^{1}$ & Oxidação $^{2}$ \\
\hline Tratamentos & 3 & 1,4219 & 0,8479 & $10,92^{\star \star}$ & $11,80^{\star *}$ \\
\hline Resíduos & 67 & 0,1302 & 0,0719 & & \\
\hline
\end{tabular}

Houve uma relação inversa entre indução de calos e oxidação, sendo 2,5 mg. $\mathrm{L}^{-1}$ de dicamba mais eficiente em combinação com BAP a 0,20 ou a $1,0 \mathrm{mg} \cdot \mathrm{L}^{-1}$ $(0,89$ e $4,44 \mu \mathrm{M}$, respectivamente), tanto na indução de calos $(82,67 \%$ e $77,42 \%$ dos explantes, respectivamente) quanto na oxidação dos explantes (notas 1,06 e 0,82, respectivamente) (Tabela 53). A utilização de BAP em combinação com outros reguladores de crescimento (TDZ, 2,4-D, NAA) tem sido eficiente na indução de calos e regeneração de plantas (Caboni et al., 2000; lantcheva et al., 1999; Oldach et al., 2001). Ressalte-se que quanto menor o índice de oxidação melhor a indução de calos, pois os compostos fenólicos inibem a divisão celular e causam a morte de células.

Tabela 53. Teste de comparação de média de indução de calos e đidação de explantes em meio básico de cultura SH suplementado com dicamba a 2,5 mg. $\mathrm{L}^{-1}$ em combinação com diferentes concentrações de BAP, após 45 dias de cultivo.

\begin{tabular}{lccc}
\hline BAP $\left(\mathrm{mg}^{-1}{ }^{-1}\right)$ & Calos $\left(\right.$ Média $\left.^{1}\right)$ & Calos/total $(\%)$ & Oxidação (Média ${ }^{1}$ ) \\
\hline 0,00 & 0,53 bc & $33 / 106(31,33)$ & $1,86 \mathbf{a}$ \\
0,05 & 0,00 c & $0 / 65(0,00)$ & $2,06 \mathbf{a}$ \\
0,20 & $1,37 \mathbf{a}$ & $62 / 75(82,67)$ & $1,06 \mathbf{b}$ \\
1,00 & $1,17 \mathbf{~ a b}$ & $72 / 93(77,42)$ & $0,82 \mathbf{b}$ \\
\hline
\end{tabular}

'Médias seguidas da mesma letra não diferem entre si 
No terceiro experimento, a suplementação do meio básico MS com dicamba 2,0 mg. $\mathrm{L}^{-1}(9,05 \mu \mathrm{M})$ e BAP $0,2 \mathrm{mg} \cdot \mathrm{L}^{-1}(0,89 \mu \mathrm{M})$, em combinação com diferentes concentrações de $\mathrm{GA}_{3}$ e nitrato de prata, permitiu indução de calos que variou em notas de 0,83 a 1,73 e índice de oxidação de 0,33 a 1,17. A indução de calos apresentou diferença significativa entre os tratamentos para tipo de explante (entrenó ou folha) e meio de cultura, mas não para a interação entre ambos, enquanto a oxidação foi dependente do tipo de explante mas não do meio de cultura e houve interação significativa para explante e meio de cultura (Tabela 54).

Tabela 54. Análise da variância em fatorial $2 \times 8$ quanto a indução de calos e oxidação em dois tipos de explantes cultivados em meio básico MS suplementado com dicamba $\left(2,0 \mathrm{mg} \cdot \mathrm{L}^{-1}\right)$ e BAP (02 mg. $\left.\mathrm{L}^{-1}\right)$ em combinação com $\mathrm{GA}_{3}$ ou nitrato de prata, após 30 dias de cultivo.

\begin{tabular}{|c|c|c|c|c|c|}
\hline \multirow[t]{2}{*}{ Fontes de variação } & \multirow[t]{2}{*}{ G. L. } & \multicolumn{2}{|c|}{ Q.M. } & \\
\hline & & Calos' & Oxidação $^{2}$ & Calos' & Oxidação $^{2}$ \\
\hline $\begin{array}{l}\text { Explante (A) } \\
\text { Meio de cultura (B) } \\
\text { Fator AxB }\end{array}$ & 1 & $\begin{array}{l}0,0519 \\
0,0753 \\
0,0190\end{array}$ & & $\begin{array}{l}4,9273 \\
7,1503^{* *} \\
1,8000^{N S}\end{array}$ & $\begin{array}{l}6,4408 \\
2,1090^{\text {NS }} \\
5,7709^{* *}\end{array}$ \\
\hline $\begin{array}{l}\text { Tratament } \\
\text { Resíduos }\end{array}$ & & & $\begin{array}{l}0,1623 \\
0,0395\end{array}$ & - & - \\
\hline \multicolumn{6}{|c|}{$\begin{array}{l}\text { Média geral }=1,3027 ; \text { desvio padrão }=0,1026 ; C V=7,88 \% \\
{ }^{2} \text { Média geral }=1,1019 ; \text { desvio padrão }=0,1988 ; \mathrm{CV}=18,04 \% \\
{ }^{*}{ }^{* *} \text { Significativo ao nível de } 5 \% \text { e } 1 \% \text { de probabilidade, respectivamente } \\
{ }^{2 S} \text { Não significativo }\end{array}$} \\
\hline \multicolumn{6}{|c|}{$\begin{array}{l}\text { O explante do tipo segmento de entrenó mostrou-se menos vulnerável à } \\
\text { oxidação, particularmente em meio de cultura com } \mathrm{GA}_{3} \text {, pois o nitrato de prata foi mais } \\
\text { eficiente no controle da oxidação em folha, principalmente à concentração de } 100 \\
\mathrm{mg}^{-\mathrm{L}^{-1}} \text {. O tratamento com } \mathrm{GA}_{3} \text { a } 5,0 \mathrm{mg} \cdot \mathrm{L}^{-1} \text { destacou-se na indução de calos }(1,73) \text {, } \\
\text { mas não apresentou diferença significativa com as outras concentrações acima de } \\
\text { zero, enquanto com o nitrato de prata foi eficiente no controle da oxidação, mas inibiu a } \\
\text { indução de calos àmedida que a concentração aumentou (Tabela 55). Ácido giberélico } \\
\left(\mathrm{GA}_{3}\right) \text { foi empregado para indução de embriões somáticos em Acacia mangium e } \\
\text { nitrato de prata foi benéfico na indução de calos embriogênicos em milheto (Oldach et } \\
\text { al., 2001). }\end{array}$} \\
\hline
\end{tabular}


Tabela 55. Efeito de meio básico de cultura MS suplementado com dicamba (2,0 mg.L' $\left.{ }^{1}\right)$ e BAP (02 mg. $\left.\mathrm{L}^{-1}\right)$ em combinação com $\mathrm{GA}_{3}$ ou nitrato de prata quanto a indução de calos e índice de oxidação em dois tipos de explantes, após 30 dias de cultivo.

\begin{tabular}{|c|c|c|c|c|c|c|c|c|}
\hline \multirow{2}{*}{$\begin{array}{l}\text { Tratamento } \\
\left(\mathrm{mg}^{\left.-\mathrm{L}^{-1}\right)}\right.\end{array}$} & \multicolumn{3}{|c|}{ Calos } & \multicolumn{5}{|c|}{ Oxidação } \\
\hline & Entrenó & Folha & Média $^{2}$ & Entrenó & & & Folha & Média $^{2}$ \\
\hline $\mathrm{GA}_{30,0}$ & 1,00 & 1,00 & $1,00 \quad$ bc & $0,53 \mathbf{a}$ & $\bar{A}$ & $A$ & $0,53 \mathbf{a b}$ & $0,53 \mathbf{a b}$ \\
\hline $\mathrm{GA}_{30,1}$ & 1,32 & 1,32 & $1,32 \mathbf{a b}$ & $0,61 \mathbf{a}$ & B & A & $1,86 \mathbf{a}$ & $1,17 \mathbf{a}$ \\
\hline $\mathrm{GA}_{30,5}$ & 1,44 & 1,53 & $1,49 \mathbf{a b}$ & $0,75 \mathbf{a}$ & A & A & $0,75 \mathbf{a b}$ & $0,75 \mathbf{a b}$ \\
\hline $\mathrm{GA}_{31,0}$ & 1,66 & 0,87 & $1,24 \mathbf{a b c}$ & $0,53 \mathbf{a}$ & B & A & $1,44 \mathbf{a}$ & $0,95 \mathbf{a b}$ \\
\hline $\mathrm{GA}_{35,0}$ & 1,99 & 1,48 & $1,73 \mathbf{a}$ & $0,00 \mathbf{a}$ & B & A & $1,84 \mathbf{a}$ & $0,75 a b$ \\
\hline $\mathrm{NP}_{100}$ & 1,11 & 1,00 & 1,05 bc & $0,75 \mathbf{a}$ & $A$ & B & $0,00 \quad \mathbf{b}$ & $0,33 \quad \mathbf{b}$ \\
\hline $\mathrm{NP}_{200}$ & 1,00 & 1,00 & $1,00 \quad$ bc & $0,55 \mathbf{a}$ & $A$ & A & $0,55 \mathbf{a b}$ & $0,55 \mathbf{a b}$ \\
\hline $\mathrm{NP}_{400}$ & 0,89 & 0,78 & $0,83 \quad \mathbf{c}$ & $0,89 \mathbf{a}$ & $A$ & A & $0,65 a b$ & $0,77 \mathrm{ab}$ \\
\hline Média $^{2}$ & $1,28 \mathrm{~A}$ & $1,11 \mathrm{~B}$ & 1,20 & $0,56 \mathrm{~B}$ & & & $0,88 \mathrm{~A}$ & 0,72 \\
\hline
\end{tabular}

No quarto experimento o uso de dicamba a $20 \mu \mathrm{M}$ em combinação com BAP e/ou caseína hidrolisada a $500 \mathrm{mg} \cdot \mathrm{L}^{-1}$ não apresentou diferença entre os tratamentos tanto para indução de calos quanto para controle da oxidação (Tabela 56).

Tabela 56. Análise da variância de média de indução de calos e oxidação de explantes em meio básico de cultura SH suplementado com dicamba a $20 \mu \mathrm{M}$ em combinação com BAP e caseína hidrolisada, após 45 dias de cultivo.

\begin{tabular}{|c|c|c|c|c|c|}
\hline \multirow[t]{2}{*}{ Causas de variação } & \multirow[t]{2}{*}{ G. L. } & \multicolumn{2}{|c|}{ Q. M. } & \multicolumn{2}{|c|}{$\mathrm{F}$} \\
\hline & & Calos & Oxidação $^{2}$ & Calos & Oxidação $^{2}$ \\
\hline Tratamentos & 3 & 0,0556 & 0,0851 & $4,02^{\text {NS }}$ & $3,68^{\mathrm{NS}}$ \\
\hline Resíduos & 8 & 0,0138 & 0,0617 & & \\
\hline
\end{tabular}

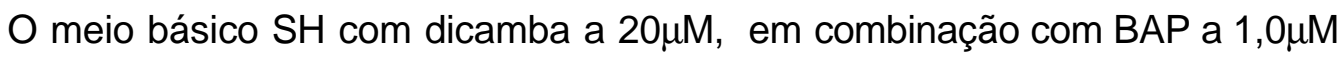
e caseína hidrolisada (500 mg. $\mathrm{L}^{-1}$ ), mostrou-se mais favorável à indução de calos (100\% e nota de 1,46$)$, principalmente por controlar o nível de oxidação a zero (Tabela 57). Resultados promissores foram conseguidos por Arya et al. (2000) para indução de 
calos embriogênicos em Pinus roxburghii ao utilizarem em combinação com 2,4-D, BA e caseína hidrolisada.

Tabela 57. Teste de comparação de média de indução de calos e oxidação de explantes em meio básico de cultura $\mathrm{SH}$ suplementado com dicamba a $20 \mu \mathrm{M}$ em combinação com BAP e caseína hidrolisada, após 45 dias de cultivo.

\begin{tabular}{cccccc}
\hline $\begin{array}{c}\text { Dic. } \\
(\mu \mathrm{M})\end{array}$ & $\begin{array}{c}\text { BAP } \\
(\mu \mathrm{M})\end{array}$ & $\begin{array}{c}\text { Caseína } \\
\left(\mathrm{mg} \cdot \mathrm{L}^{-1}\right)\end{array}$ & Calos (Média) $^{\mathbf{1}}$ & Calos/total (\%) & Oxidação (Média) $^{\mathbf{1}}$ \\
\hline 20 & 0 & 0 & $0,64 \mathbf{b}$ & $10 / 15(66,67)$ & $0,31 \mathbf{a}$ \\
20 & 1 & 0 & $1,07 \mathbf{~ a b}$ & $15 / 15(100,0)$ & $0,00 \mathbf{a}$ \\
20 & 0 & 500 & $1,00 \mathbf{~ a b}$ & $20 / 20(100,0)$ & $0,00 \mathbf{a}$ \\
20 & 1 & 500 & $1,46 \mathbf{~ a ~}$ & $15 / 15(100,0)$ & $0,00 \mathbf{a}$ \\
\hline
\end{tabular}

'Médias seguidas pela mesma letra não diferem entre si

No quinto experimento, a combinação de $\operatorname{TDZ}(0,2$ a $10,0 \mu \mathrm{M})$ em combinação com IAA $(0,1$ e $5 \mu \mathrm{M})$, com raras exceções, não induziu calos e o nível de oxidação variou de 0,58 a 2,67, sendo esta oxidação crescente com o aumento da concentração de TDZ, principalmente em combinação com $1 \mu \mathrm{M}$ de IAA (Tabela 58).

Esses resultados foram contrastantes com os sucessos de indução de calos embriogênicos obtidos por Xie \& Hong (2001) em Acácia mangium ao empregarem 5 a $10 \mu \mathrm{M}$ de TDZ e IAA 1 a $10 \mu \mathrm{M}$.

Tabela 58. Indução de calos e nível de oxidação de explante em meio SH suplementado com tidiazuron em combinação com IAA, após 30 dias de cultivo.

\begin{tabular}{|c|c|c|c|c|c|c|c|c|}
\hline \multirow{3}{*}{$\begin{array}{l}\text { TDZ } \\
(\mu \mathrm{M})\end{array}$} & \multicolumn{4}{|c|}{ Calos/total } & \multicolumn{4}{|c|}{ Nível de oxidação } \\
\hline & \multicolumn{3}{|c|}{ IAA $(\mu \mathrm{M})$} & \multirow[t]{2}{*}{ Total } & \multicolumn{3}{|c|}{ IAA $(\mu \mathrm{M})$} & \multirow[t]{2}{*}{ Média } \\
\hline & 0 & 1 & 5 & & 0 & 1 & 5 & \\
\hline 0,2 & $0 / 12$ & $0 / 14$ & $0 / 12$ & $0 / 38$ & 0,75 & 1,4 & 1,58 & 1,24 \\
\hline 1,0 & $1 / 13$ & $0 / 12$ & $2 / 12$ & $3 / 37$ & 1,57 & 1,75 & 0,58 & 1,30 \\
\hline 5,0 & $0 / 24$ & $0 / 12$ & $1 / 18$ & $1 / 54$ & 1,79 & 2,08 & 1,82 & 1,90 \\
\hline 10,0 & $0 / 12$ & $0 / 24$ & $0 / 13$ & $0 / 49$ & 2,67 & 2,13 & 2,30 & 2,37 \\
\hline Total & $1 / 61$ & $0 / 62$ & $3 / 55$ & $4 / 178$ & 1,70 & 1,84 & 1,57 & Média \\
\hline
\end{tabular}


No teste de dicamba entre 1 a $20 \mu \mathrm{M}$ em combinação com BAP desde 0 a 5 $\mu \mathrm{M}$, mais uma vez foi observada a maior quantidade de calos formados em explantes

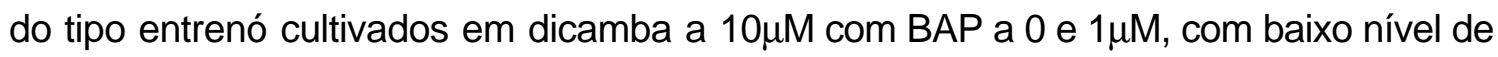
oxidação que variou de 0 a 1,00 (Tabela 59).

Tabela 59. Indução de calos e nível de oxidação em dois tipos de explante em meio SH suplementado com dicamba em combinação com BAP, após 30 dias de cultivo.

\begin{tabular}{|c|c|c|c|c|c|c|c|c|}
\hline \multirow{3}{*}{$\begin{array}{l}\text { Dic. } \\
(\mu \mathrm{M})\end{array}$} & \multicolumn{4}{|c|}{ Entrenó } & \multicolumn{4}{|c|}{ Folha } \\
\hline & \multicolumn{3}{|c|}{ BAP $(\mu \mathrm{M})$} & \multirow[t]{2}{*}{ Média } & \multicolumn{3}{|c|}{ BAP $(\mu \mathrm{M})$} & \multirow[t]{2}{*}{ Média } \\
\hline & 0 & 1 & 5 & & 0 & 1 & 5 & \\
\hline 1 & 0,00 & 1,17 & 0,17 & 0,45 & 0,00 & 0,50 & 0,00 & 0,17 \\
\hline 5 & - & 1,33 & 0,75 & 1,04 & - & 0,17 & 0,25 & 0,21 \\
\hline 10 & 2,25 & 2,17 & 1,00 & 1,81 & 0,25 & 0,75 & 0,33 & 0,44 \\
\hline 20 & 0,50 & 1,67 & 1,17 & 1,11 & 0,50 & 0,83 & 0,00 & 0,44 \\
\hline Média $^{1}$ & 0,92 & 1,56 & 0,77 & & 0,25 & 0,56 & 0,15 & \\
\hline 1 & 0,00 & 0,00 & 1,00 & 0,33 & 1,00 & 0,00 & 0,33 & 0,44 \\
\hline 5 & & 0,33 & 0,25 & 0,29 & - & 0,33 & 0,50 & 0,42 \\
\hline 10 & 0,75 & 0,50 & 0,33 & 0,53 & 0,50 & 0,25 & 0,50 & 0,42 \\
\hline 20 & 0,00 & 0,17 & 0,17 & 0,11 & 0,00 & 0,50 & 0,50 & 0,33 \\
\hline Média $^{2}$ & 0,25 & 0,25 & 0,44 & & 0,50 & 0,36 & 0,46 & \\
\hline
\end{tabular}

A utilização de embriões zigóticos como explantes, visando a obtenção de calos apresentou resultados mais favoráveis em meio SH que continha dicamba 5 ou $10 \mu \mathrm{M}$ em combinação com 0 ou $1 \mu \mathrm{M}$ de BAP, sendo que dicamba a $10 \mu \mathrm{M}$ e BAP a $1 \mu \mathrm{M}$ foram mais eficientes (Figura 19e). Por outro lado, em meio sem reguladores de crescimento houve desenvolvimento do embrião e diferenciação de raízes, enquanto com BAP $(1 \mu \mathrm{M})$, houve diferenciação de sistema caulinar (Tabela 60). Resultados contratantes foram obtidos por Joseph et al. (1996) em que embriões cultivados em meio de cultura SH sem regulador de crescimento responderam por formação de calos. 
Tabela 60. Respostas de embriões zigóticos em cultivo em meio básico de cultura SH suplementado com dicamba em combinação com BAP, após 4 semanas.

\begin{tabular}{|c|c|c|c|c|c|c|}
\hline \multicolumn{2}{|c|}{$(\mu \mathrm{M})$} & \multicolumn{4}{|c|}{ Embriões } & \multirow[t]{2}{*}{ Total } \\
\hline Dic & BAP & Calos & Estável & Diferenciados & Necrosados & \\
\hline 0 & 0 & 0 & 7 & $8^{R}$ & 1 & 16 \\
\hline 0 & 1 & 0 & 4 & $2^{A}$ & 0 & 6 \\
\hline 1 & 0 & 3 & 9 & 1 & 0 & 13 \\
\hline 5 & 0 & 6 & 4 & 5 & 0 & 15 \\
\hline 10 & 0 & 9 & 9 & 0 & 0 & 18 \\
\hline Total & & 18 & 22 & 6 & 0 & 46 \\
\hline 1 & 1 & 7 & 7 & 1 & 0 & 15 \\
\hline 5 & 1 & 8 & 7 & 0 & 0 & 15 \\
\hline 10 & 1 & 8 & 11 & 0 & 0 & 19 \\
\hline Total & & 23 & 25 & 1 & 0 & 49 \\
\hline 1 & 5 & 2 & 4 & 0 & 0 & 6 \\
\hline 5 & 5 & 0 & 3 & 0 & 0 & 3 \\
\hline 10 & 5 & 0 & 6 & 0 & 0 & 6 \\
\hline Total & & 2 & 13 & 0 & 0 & 15 \\
\hline
\end{tabular}

${ }^{\mathrm{R}}$ Embriões com diferenciação de raiz

AEmbriões com diferenciação caulinar

Os tratamentos, a que foram submetidos os embriões zigóticos para indução de calos, não apresentaram diferença significativa ao comparar separadamente os efeitos das diferentes concentrações de dicamba e de BAP (Tabela 61).

Tabela 61. Teste qui-quadrado quanto a efeito de dicamba e BAP em meio básico de cultura SH para indução de calos em embriões zigóticos, após 30 dias de cultivo.

\begin{tabular}{|c|c|c|c|c|c|c|c|}
\hline \multirow[t]{2}{*}{ Dic. $(\mu \mathrm{M})$. } & \multicolumn{3}{|c|}{ Embriões } & \multirow[t]{2}{*}{ BAP } & \multicolumn{3}{|c|}{ Embriões } \\
\hline & Calos & não calos & Total & & calos & não calos & Total \\
\hline 1 & 12 & 22 & 34 & 0 & 18 & 28 & 46 \\
\hline 5 & 14 & 19 & 33 & 1 & 23 & 26 & 49 \\
\hline 10 & 17 & 26 & 43 & 5 & 2 & 13 & 15 \\
\hline \multirow[t]{2}{*}{ Total } & 43 & 67 & 110 & & 43 & 67 & 110 \\
\hline & \multicolumn{3}{|c|}{$\chi^{2}=0,363^{\mathrm{NS}}$ g.I. $=2$} & \multicolumn{4}{|c|}{$\chi^{2}=5,44^{\mathrm{NS}} ;$ g.I. $=2$} \\
\hline
\end{tabular}

Dos calos produzidos e transferidos para meios líquidos, células foram isoladas e mantidas sob cultivos por vários meses em suspensão. Entretanto, ao 
serem transferidas tanto para meios líquidos ou meios semi-sólidos nos diversos tratamentos aplicados seja sob luz (fotoperíodo de 16 horas de luz) ou escuro, visando a regeneração de plantas tanto por via organogênese e/ou embriogênese, essas células tornaram-se escurecidas e conseqüentemente ocorreu morte celular. Algumas células foram mantidas em suspensão, dividiram-se e apresentaram aspecto de início de formação de embrião somático mas não tiveram continuidade (Figura 19 f-i).

Outrossim, ao utilizar meio de cultura líquido com metade da concentração de sais de $\mathrm{SH}$ e sacarose a 1,5 a 4,5\% (p/v) sob agitação de $100 \mathrm{rpm}$, conforme trabalho de Joseph et al. (1996) não se obteve embriões somáticos e tampouco a regeneração de plantas. Portanto, considerando os resultados obtidos, a indução de calos é viável

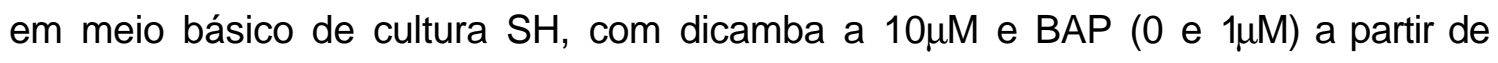
diferentes explantes, segmentos de entrenós, folhas e embriões somáticos. O processo de regeneração de plantas necessita ser investigado, principalmente para estabelecer condições apropriadas para evitar o escurecimento da cultura e posteriormente, adequar o protocolo proposto por Joseph et al. (1996) de regeneração de plantas via embriogênese somática a partir de embriões zigóticos. 


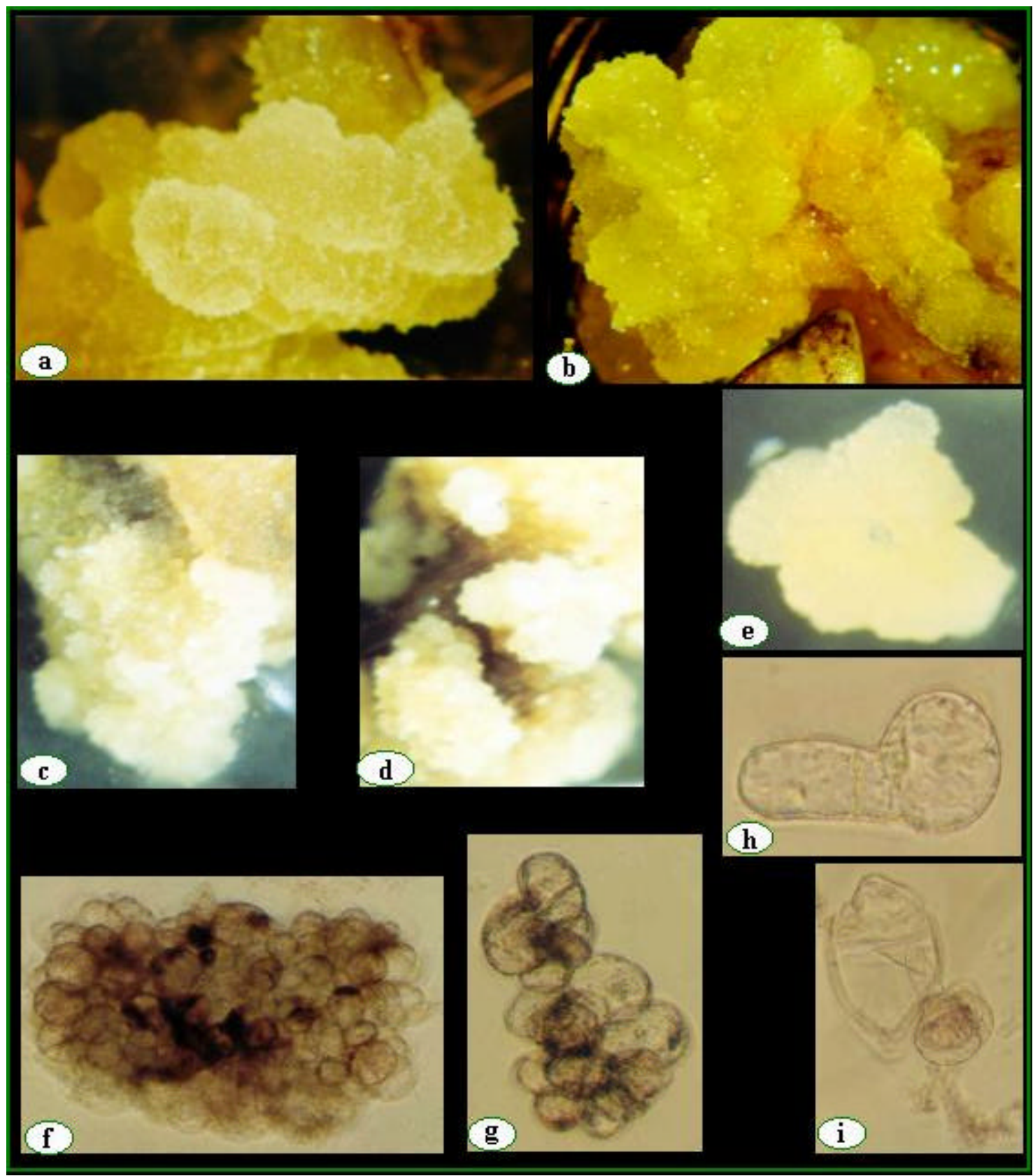

Figura 19 - Indução de calos e obtenção de células em suspensão.

a-e) Indução de calos em diferentes explantes: a, c, d - segmentos de entrenós; b folhas; e - embriões zigóticos

f-g) Células em suspensão

h-i) Células em divisão e em processo inicial de diferenciação de embrião somático 


\subsection{Mutagênese e seleção de variantes contra a doença fusariose}

Determinou-se a dose de radiação gama apropriada para induzir mutações em gemas in vitro; a concentração e forma de esterilização do filtrado da cultura do fungo Fusarium solani f. sp. piperis, como agente seletivo de gemas de plantas susceptíveis em meio de multiplicação; seleção in vitro de variantes sobreviventes ao agente seletivo; e a concentração e modo de aplicação de suspensão de esporos do fungo Fusarium solani f. sp. piperis para seleção de plantas susceptíveis à doença fusariose em casa-de-vegetação.

\subsubsection{Radiossensitividade de gemas in vitro à radiação gama}

As gemas submetidas às diferentes doses de radiação gama (0 a 80Gy) apresentaram comportamentos diferentes. Às doses maiores que $40 \mathrm{~Gy}$, estas não sobreviveram (60 e 80Gy), e àdose de 10 Gy os efeitos foram de menor intensidade, pois as respostas in vitro foram próximas às gemas não submetidas à irradiação. Ressalte-se que a média de proliferação de novas gemas por explante a partir de $V_{2}$ variou de 1,71 a 2,46 gemas por explante, sendo 2,22, 2,46, 1,93, 1,71 e 2,31 nas doses de $0,10,20,30$ e 40 Gy, respectivamente, cuja média relativa æ̀s gemas irradiadas $(2,10)$ foi próxima à média para as gemas não irradiadas. Após os vários ciclos de subcultivos, 4.105 gemas provenientes das gemas inicialmente irradiadas foram transferidas para meio de cultura com agente seletivo (Tabela 62).

Tabela 62. Gemas submetidas àirradiação gama, média de multiplicação a partir de $\mathrm{V}_{2}$ e gemas transferidas para seleção in vitro.

\begin{tabular}{lccc}
\hline Dose (Gy) & Gemas iniciais & Média de gemas/expl. & Gemas em seleção \\
\hline 0 & 161 & 2,22 & - \\
& & & 2.332 \\
20 & 178 & 2,46 & 532 \\
30 & 263 & 1,93 & 160 \\
40 & 268 & 1,71 & 1.081 \\
& 260 & 2,31 & 4.105 \\
\hline
\end{tabular}

Tédia das médias para as doses com exceção de 0Gy 
No experimento de determinação de radiossensitividade com 0 a 50 Gy de radiação gama, em que as condições de micropropagação estavam estabelecidas, observou-se que àmedida que a dose foi crescente maior o efeito fisiológico, tanto na taxa de sobrevivência dos explantes quanto na diferenciação de gemas e peso dos explantes em cultivo. Os coeficientes de determinação $\left(R^{2}\right)$ foram acima de 0,91 , o que representou uma correlação acima de $95 \%$, e as equações obtidas permitiram calcular as doses de radiação gama adequadas, de acordo com os critérios de redução de $30 \%$ e 50\% dos parâmetros avaliados,as quais variaram de 14,17 a 18,47 Gy para $30 \%$ e de 23,62 a 30,78 Gy para redução de 50\% (Tabela 63).

Tabela 63. Efeito da dose de irradiação gama na sobrevivência, gemas e peso por explante, equação da reta, coeficiente de determinação e dose adequada para redução de 70 e $30 \%$ dos parâmetros avaliados.

\begin{tabular}{cccc}
\hline \multirow{2}{*}{$\begin{array}{c}\text { Dose } \\
\text { Gy })\end{array}$} & Sobrevivência & Gemas/explante & Peso/explante \\
\cline { 2 - 4 } & 100,0 & 2,96 & 1,18 \\
20 & 87,86 & 1,47 & 0,93 \\
30 & 51,57 & 0,51 & 0,59 \\
40 & 32,83 & 0,34 & 0,31 \\
50 & 19,60 & 0,22 & 0,20 \\
& & & \\
Equação & $\mathrm{Y}=-1,7395 \mathrm{x}+107,08$ & $\mathrm{Y}=-0,0572 \mathrm{x}+2,7024$ & $\mathrm{Y}=-0,01198 \mathrm{x}+1,1847$ \\
$\mathrm{R}^{2}$ & 0,9322 & 0,9152 & 0,9501 \\
$70 \%{ }^{1}$ & $74,956=18,47 \mathrm{~Gy}$ & $1,8917=14,17 \mathrm{~Gy}$ & $0,8293=17,95 \mathrm{~Gy}$ \\
$50 \%{ }^{2}$ & $53,54=30,78 \mathrm{~Gy}$ & $1,3512=23,62 \mathrm{~Gy}$ & $0,5924=29,91 \mathrm{~Gy}$ \\
\hline${ }^{T}$ Redução de $30 \%$ cada parâmetro avaliado de acordo com a equação da reta \\
${ }^{2}$ Redução de 50\% de cada parâmetro avaliado de acordo com a equação da reta
\end{tabular}

Os dados tiveram comportamentos correspondentes e correspondência funcional entre a dose empregada e os resultados obtidos, cujo gráfico de dispersão e equação da reta são apresentados nas Figuras 20, 21 e 22. Ressalte-se que a maior correlação de dose de irradiação foi observada com peso do explante, seguido pela sobrevivência e número de gemas diferenciadas por explantes.

Baseado nesses efeitos fisiológicos da irradiação gama (Figura 23) e na sugestão de Predieri (2001), optou-se pelo tratamento mutagênico à dose de 20Gy, pois esta provocaria um efeito fisiológico superior a $30 \%$ e inferior a $50 \%$ para redução dos parâmetros avaliados e foi a dose estabelecida por Ando et al. (1984), a partir da 
qual selecionou três plantas sobreviventes através de seleções artificiais e naturais contra a doença fusariose. Outrossim, doses maiores provocam no DNA, maiores alterações, que são na maioria maléficas e podem comprometer outros caracteres desejáveis da cultivar original (Przybyla, 1994), e no caso da pimenta-do-reino, por ser uma planta de propagação vegetativa e com poucos estudos realizados no melhoramento genético, esta apresenta alta heterozigosidade, portanto mais sujeita æ̀s alterações.

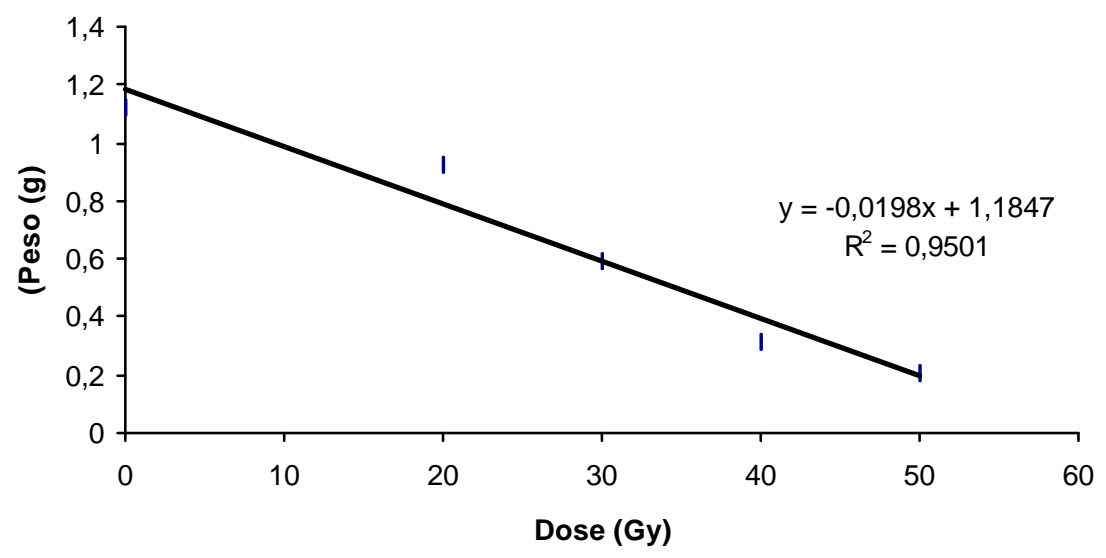

Figura 20 - Efeito da radiação gama no peso dos explantes.

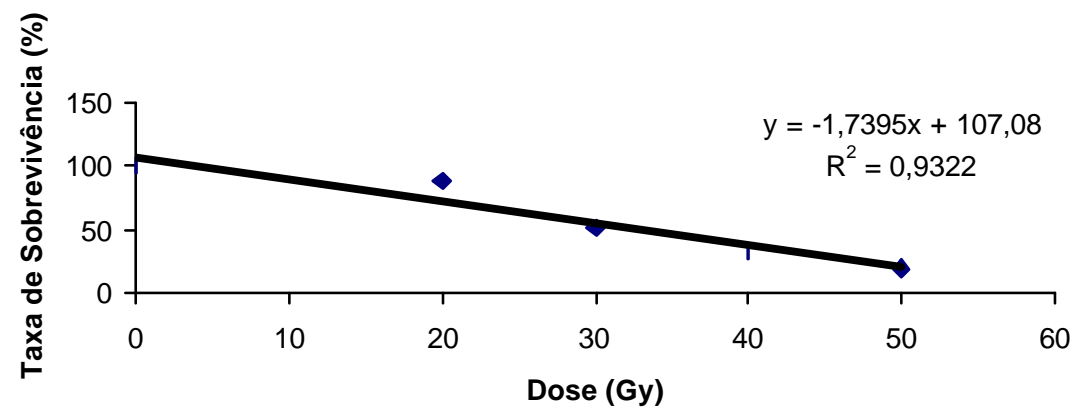

Figura 21 - Efeito da radiação gama na sobrevivência dos explantes. 


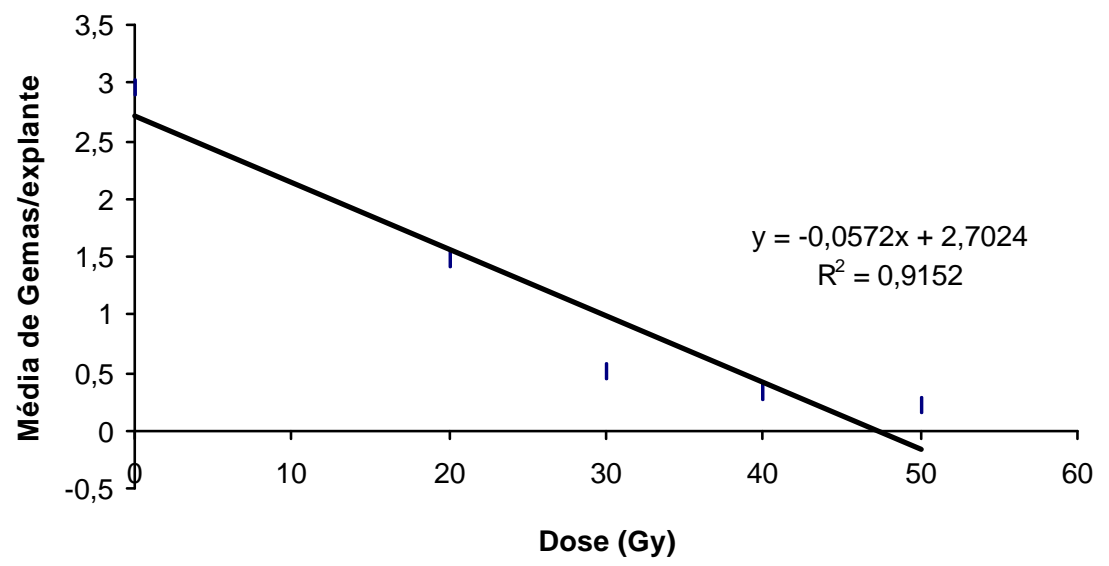

Figura 22 - Efeito da irradiação gama no número de gemas por explantes.

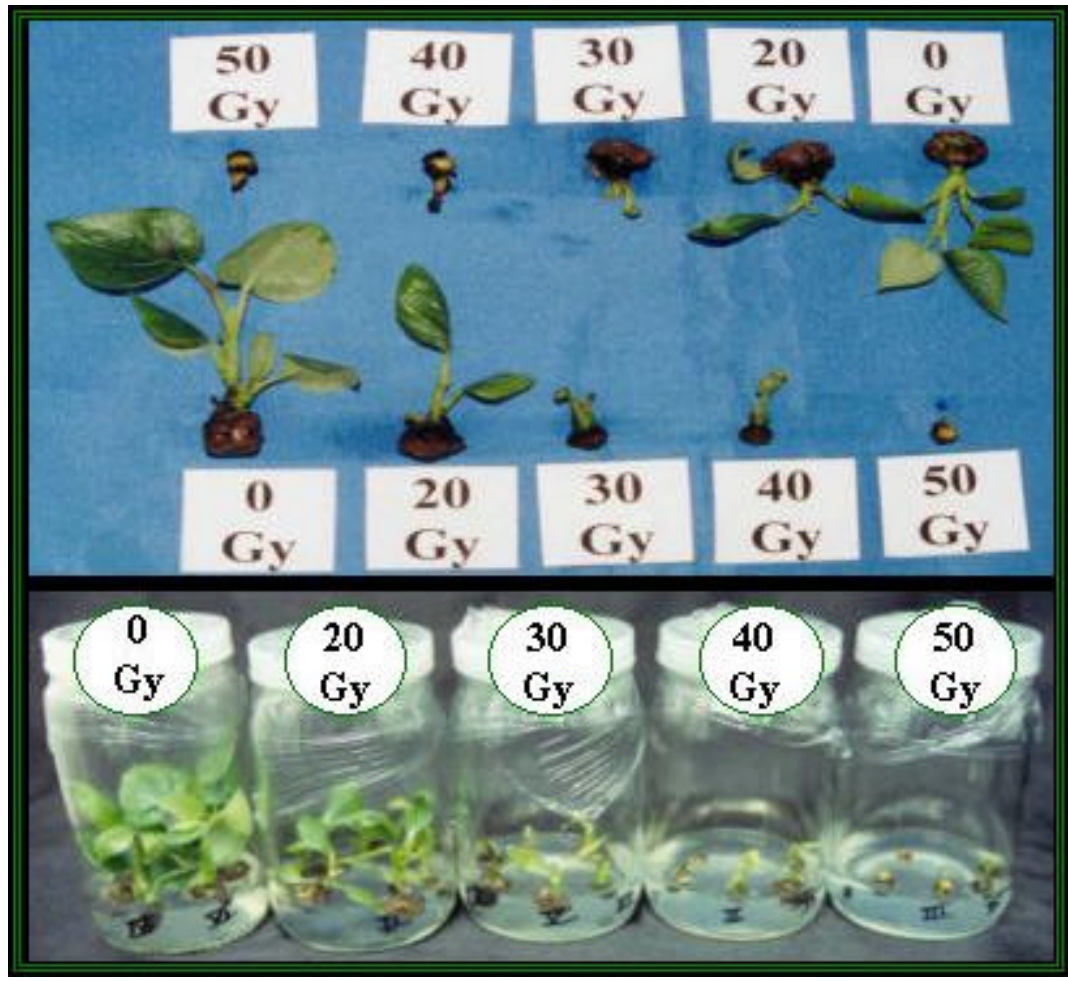

Figura 23 - Efeito da radiação gama nas doses de 0 a 50 Gy em gemas in vitro. 
Após a escolha da dose a ser aplicada, 1.024 gemas foram submetidas a 20 Gy de irradiação gama e 741 gemas sobreviveram, ou seja $72,36 \%$ do total irradiado, próximo ao determinado pela equação estabelecida que seria de $72,29 \%$. Quanto ao número de gemas diferenciadas por explante, foi obtida a média de 1,64 contra a média esperada de 1,56. Portanto, os resultados obtidos com a dose de 20 Gy foram muito próximos aos esperados. As gemas sobreviventes à irradiação gama estão se multiplicando normalmente e após o terceiro subcultivo - a partir do qual pode-se obter mutantes não quiméricos (Ahloowalia \& Maluszynski, 2001) — serão submetidas ao processo de seleção in vitro.

\subsubsection{Fitotoxicidade in vitro do filtrado de cultura do fungo Fusarium solani f. sp. piperis}

As gemas cultivadas em meio de cultura de multiplicação com diferentes concentrações do meio Czapek-Dox (0 a 50\%) apresentaram comportamento semelhante após 45 dias de cultivo, tanto quanto a proliferação de gemas quanto a sobrevivência. A média de número de gemas por explante variou de 2,67 a 3,20 e de taxa de sobrevivência, de 69,79\% a $100 \%$, respectivamente para 0 a $50 \%$ de concentração de Czapek-Dox (Tabela 64). Ressalte-se que as gemas consideradas não sobreviventes apresentavam os tecidos verdes mesmo não havendo diferenciação de novas gemas. Acredita-se que os compostos constituintes no meio Czapek-Dox não tiveram influência negativa significativa nas respostas in vitro das culturas. Este aspecto foi fundamental para que os testes do uso do filtrado da cultura do fungo em meio de multiplicação de gema fossem realizados para determinação da concentração deste como agente seletivo, de modo a evitar a seleção para outros constituintes do meio de cultura que não os constituintes do filtrado da cultura do fungo, como sugere Daub (1986). 
Tabela 64. Efeito da adição de diferentes concentrações do meio de cultura CzapekDox em meio de multiplicação de gemas na sobrevivência e proliferação de gemas por explante.

\begin{tabular}{|c|c|c|c|c|c|c|c|c|}
\hline \multirow[t]{2}{*}{ F.V. } & \multirow[t]{2}{*}{ G.L. } & \multicolumn{2}{|r|}{ Q. M. } & \multicolumn{2}{|r|}{ F. } & \multirow[t]{2}{*}{ Trat. $^{1}$} & \multirow{2}{*}{$\begin{array}{c}\text { Sobrev. }^{4} \\
(\%)\end{array}$} & \multirow[t]{2}{*}{ Gemas/expl. } \\
\hline & & Sobrev $^{2}$. & Gemas/expl. ${ }^{3}$ & Sobrev. & Gemas/expl. & & & \\
\hline Trat. $^{1}$ & 4 & 0,0065 & 0,1441 & $2,06^{\mathrm{NS}}$ & $1,32^{\mathrm{NS}}$ & $\begin{array}{l}0 \% \\
20 \% \\
30 \%\end{array}$ & $\begin{array}{l}100,0 \mathbf{a} \\
93,19 \mathbf{a} \\
89,83 \mathbf{a}\end{array}$ & $\begin{array}{l}3,20 \mathbf{a} \\
3,00 \mathbf{a b} \\
3,15 \mathbf{a b}\end{array}$ \\
\hline Res. & 14 & 0,0032 & 0,1094 & & & $\begin{array}{l}40 \% \\
50 \%\end{array}$ & $\begin{array}{l}79,48 \mathbf{a} \\
69,79 \mathbf{a}\end{array}$ & $\begin{array}{r}2,78 \mathbf{a b} \\
2,67 \quad \mathbf{b}\end{array}$ \\
\hline
\end{tabular}

Meio de multiplicação de gemas com diferentes concentrações de Czapek-Dox (0 a 50\%)

${ }^{2}$ Média geral $=87,62 \%$; desvio padrão $=4,197$; e CV=4,79\%

${ }^{2}$ Média geral=2,99; desvio padrão=0,331; e CV=11,06\%

${ }^{4}$ Médias seguidas da mesma letra não diferem estatisticamente entre

${ }^{\mathrm{NS}}$ Não significativo

Quanto ao cultivo do fungo para a obtenção de filtrado da cultura e uso como agente seletivo, a média de produção de conídios a partir dos três frascos atendeu à curva de crescimento do fungo relativo àestimativa do número de conídios por ml. Aos 8 dias de cultivo a produção de conídios atingiu cerca de $8 \times 10^{4}$, e aos 29 dias $3 \times 10^{5}$, para em seguida iniciar a redução. Outrossim, a produção de hifas quanto ao peso seco variou de 1.070 a 1.153 mg após 35 dias de cultivo, média de 1.098 mg para 200 $\mathrm{ml}$ de meio de cultura (Tabela 65).

Tabela 65. Média de produção de esporos por ml entre 8 e 35 dias do cultivo do fungo Fusarium solani f. sp. piperis em meio de cultura de Czapek-Dox e peso seco das hifas produzidas.

\begin{tabular}{lccccccc}
\hline Variáveis & \multicolumn{7}{c}{ Dias } \\
\cline { 2 - 8 } & 8 & 11 & 14 & 17 & 23 & 29 & 35 \\
\hline Esporos/ml & 79.667 & 140.667 & 181.000 & 226.000 & 308.667 & 314.667 & $\begin{array}{c}257.667 \\
1.098\end{array}$ \\
P. seco $(\mathrm{mg} / 200 \mathrm{ml})^{1}$ & & & & & & & 1.00 \\
\hline
\end{tabular}

${ }^{1}$ Média de três repetições (frascos)

A curva de crescimento indicou que entre 0 a 20 dias ocorreu a fase de maior crescimento do fungo, sendo que a partir do $23^{\circ}$ dia se iniciou a fase estacionária e após o 29ํํㅁ dia, a fase de declínio (Figura 24). Este aspecto permitiu inferir a tendência 
de que, a produção de metabólitos secundários e conseqüentemente de fitotoxinas deve estar em maior concentração nesse intervalo de tempo, entre 23 e 29 dias de cultivo (Figura 24). O filtrado de cultura do fungo Fusarium solani f. sp. piperis foi produzido também por Duarte (1993) entre 20 a 25 dias de cultivo.

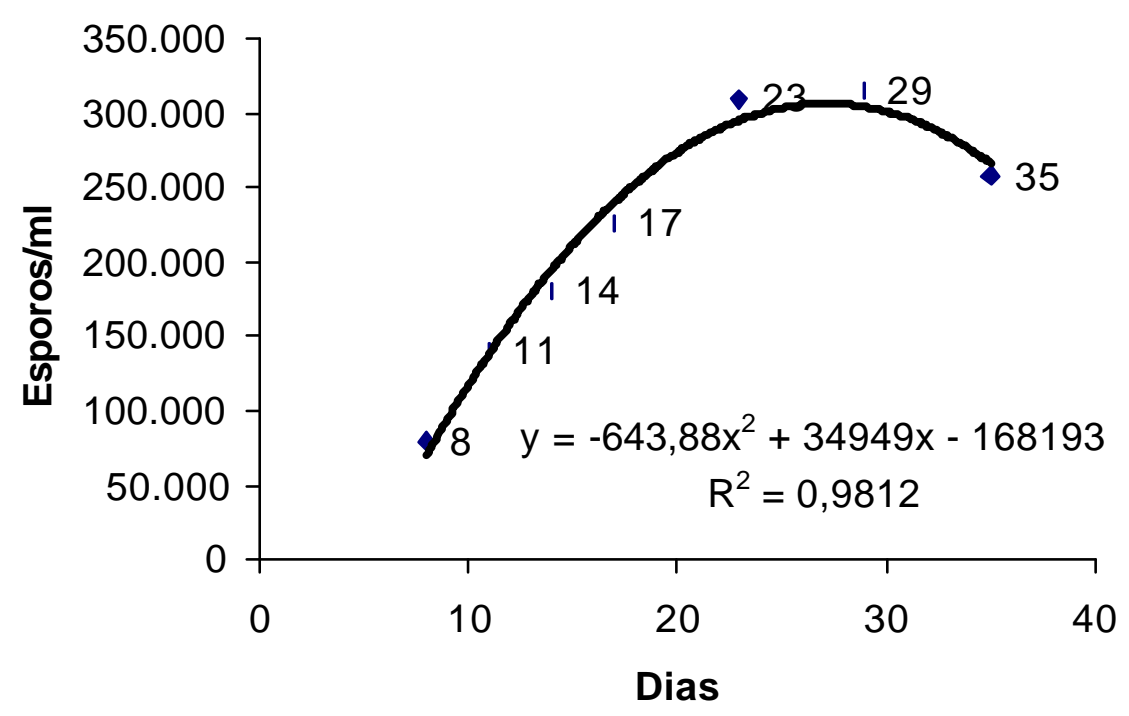

Figura 24 - Curva de crescimento do fungo Fusarium solani f. sp. piperis cultivados em meio Czapek-Dox durante 35 dias.

No teste para definição do uso de filtrado de cultura do fungo Fusarium solani f. sp. piperis, como agente seletivo para seleção in vitro, houve fitotoxicidade æ̀ gemas sob as duas formas de esterilização, através de filtro estéril (FE) e duas autoclavagens (All) (Tabela 66). Nenhuma gema se diferenciou a partir da concentração de $30 \%$ FE e estimou-se a concentração de $40 \%$ FE para causar 100\% de mortalidade de gemas de plantas susceptíveis à doença fusariose (Figura 25A e 26a-b). Sob a forma de esterilização do filtrado do fungo por duas autoclavagens (All), somente à concentração de 50\% All, não houve diferenciação das gemas. Observou-se 80, 60 e $20 \%$ de diferenciação de gemas à20, 30 e 40\% All, respectivamente. Estimou-se, pela análise de regressão, a concentração de 52,1\% All como agente seletivo para causar mortalidade de $100 \%$ de gemas susceptíveis (Figura 25B e 26c-d). Hidalgo et al. 
(1999) e Matsumoto et al. (1996) estabeleceram como agente seletivo, filtrado de cultura do fungo Fusarium subglutinans e Fusarium oxysporum f. sp. cubense, nas concentrações de $20 \%$ e $15 \%$, para seleção in vitro em abacaxizeiro e bananeira, respectivamente.

A)

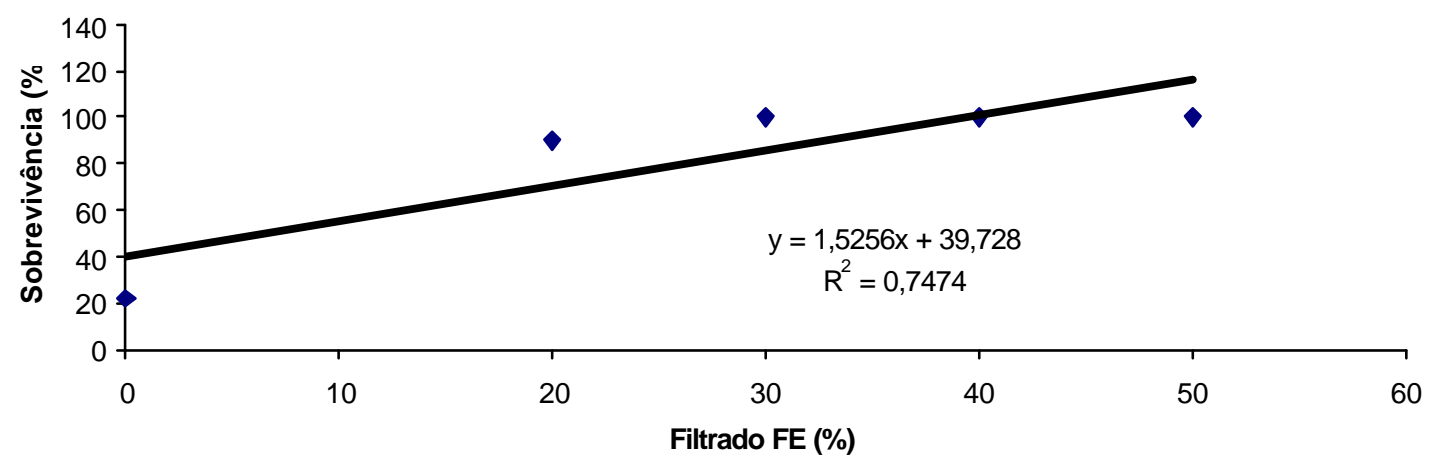

B)

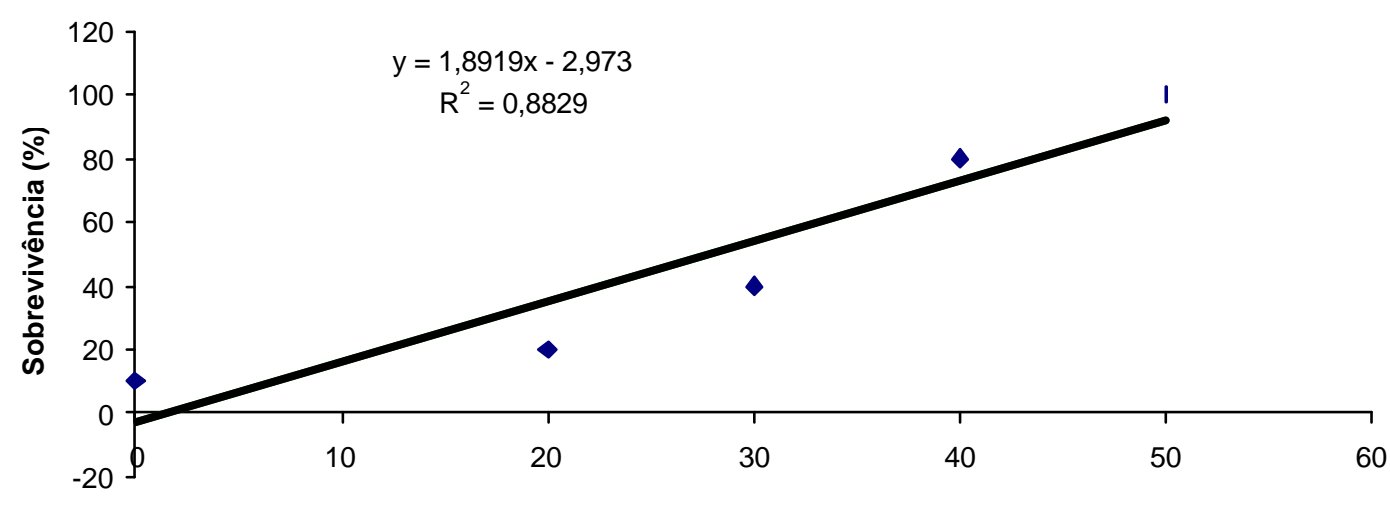

Filtrado All (\%)

Figura 25 - Efeito de filtrados FE (A) e All (B) na não diferenciação de gemas. 
Tabela 66. Efeito do filtrado em adição ao meio de cultura de multiplicação de gemas na diferenciação de gemas por explante, após 45 dias de cultivo.

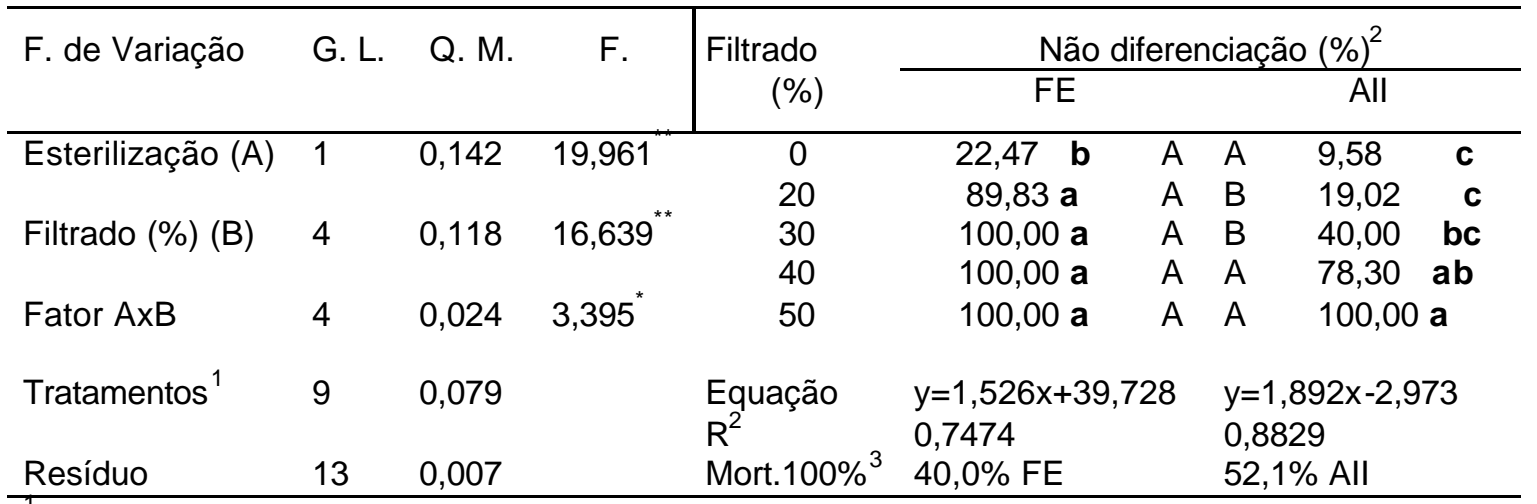

T'Média geral=62,74\%; desvio padrão=4,98.; CV=7,94\%

${ }^{2}$ Médias seguidas da mesma letra não diferem entre si. Letras minúsculas: comparação vertical; letras maiúsculas: comparação horizontal

${ }^{3}$ Concentração do filtrado para causar $100 \%$ de mortalidade de acordo com a equação da reta

*, ${ }^{*}$ Significativo ao nível de $5 \%$ e $1 \%$ de probabilidade, respectivamente

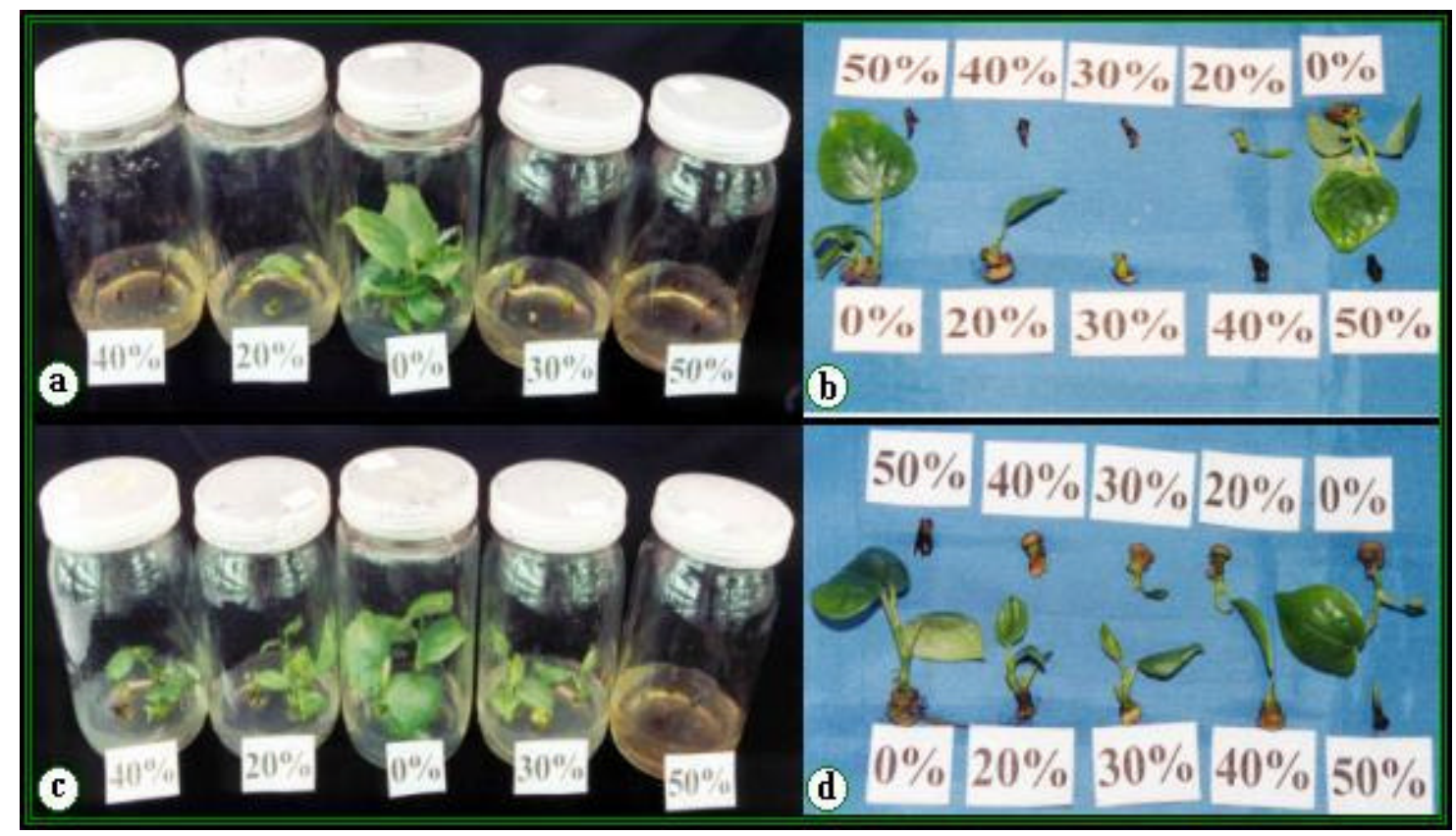

Figura 26 - Efeito de diferentes concentrações de filtrado (0, 20, 30, 40 e 50\%), como agente seletivo em meio de multiplicação de gemas.

a-b) sob a forma de esterilização por filtro estéril (FE), após 45 dias de cultivo

c-d) sob a forma de esterilização por duas autoclavagens (AlI), após 45 dias de cultivo 


\subsubsection{Seleção in vitro de variantes sobreviventes ao filtrado da cultura do fungo}

A concentração do filtrado da cultura do fungo Fusarium solani f. sp. piperis teve um papel importante na sobrevivência das gemas, tanto que as menores taxas de sobrevivência foram observadas em meio de cultura com 55\% da concentração do filtrado para todas as gemas, independente da dose de irradiação a que foram previamente submetidas. Das gemas originadas da irradiação à dose de 30Gy, nenhuma permaneceu viva na concentração de 55\% e somente três gemas foram selecionadas a 50\%, dentre 160 gemas inicialmente transferidas para meio seletivo. Por outro lado, a maior percentagem de gemas selecionadas à concentração de $50 \%$ do filtrado foi a partir das gemas originadas da irradiação à dose de 10 Gy $(11,35 \%)$ seguida por 20 Gy $(9,13 \%)$ e 40 Gy $(4,22 \%)$, o que corrobora com a tese de que quanto maior a dose de irradiação maior é o dano causado ao DNA, e conseqüentemente, maiores variações genéticas e maiores efeitos maléficos, o que torna os variantes mais débeis e por fim, menos tolerantes æ̀ condições adversas (Tabela 67).

Tabela 67. Seleção in vitro de gemas através da sobrevivência em meio de cultura com agente seletivo sob duas concentrações do filtrado do fungo, após 6 semanas de cultivo.

\begin{tabular}{lcccc|cccccccc}
\hline \multirow{2}{*}{$\begin{array}{l}\text { Dose } \\
\text { (Gy) }\end{array}$} & \multicolumn{4}{c}{ Filtrado 55\% } & \multicolumn{4}{c}{ Filtrado 50\% } & \multicolumn{3}{c}{ Geral } \\
\cline { 2 - 12 } & Vivo & Morto & Total & Sel.(\%) & Vivo & Morto & Total & Sel.(\%) & Vivo & Total & Sel.(\%) \\
\hline 10 & 123 & 961 & 1.084 & 11,35 & 550 & 698 & 1.248 & 44,07 & 673 & 2.332 & 28,86 \\
20 & 24 & 239 & 263 & 9,13 & 119 & 150 & 269 & 44,24 & 143 & 532 & 26,88 \\
30 & 0 & 97 & 97 & 0,00 & 3 & 60 & 63 & 4,76 & 3 & 160 & 1,88 \\
40 & 43 & 977 & 1.020 & 4,22 & 54 & 19 & 73 & 73,97 & 97 & 1.093 & 11,27 \\
& & & & & & & & & & & \\
Total & 190 & 2.274 & 2.464 & 7,71 & 726 & 927 & 1.653 & 43,92 & 916 & 4.117 & 22,49 \\
\hline
\end{tabular}

Ressalte-se que a concentração de $50 \%$ do agente seletivo não foi muito eficiente no processo de seleção, haja vista que mais de $40 \%$ das gemas sobreviveram, com exceção daquelas provenientes da dose de 30Gy (4,76\%). Por fim, o filtrado da cultura do fungo à dose de $55 \%$ foi significativamente mais efetivo como agente seletivo e pode ser utilizado para "screening" de materiais com potências para resistência àdoença fusariose. 
O cultivo do fungo junto com plantas susceptíveis (co-cultivo) apresentou resultados contrastantes às concentrações utilizadas, pois com $55 \%$ do filtrado a seleção foi menos efetiva (10,40\% de gemas selecionadas) do que a partir do cultivo normal do fungo, sem plantas $(4,10 \%$ de gemas selecionadas), enquanto à concentração de $50 \%$ o resultado foi favorável ao co-cultivo $(33,78 \%$ de gemas selecionadas) contra o filtrado da cultura do cultivo normal do fungo (52,01\%). Esses resultados indicaram que co-cultivo não seja a forma mais adequada de cultivo do fungo para pimenta-do-reino como reportado por Matsumoto et al. (1999a, 1999b) para bananeira. Os testes qui-quadrado para comparação de ambas concentrações entre co-cultivo e cultivo normal do fungo apresentaram resultados significativamente superiores ao nível de $0,1 \%$ de probabilidade, sendo o co-cultivo mais efetivo à concentração de 50\% e menos efetivo àconcentração de 55\% (Tabela 68).

Tabela 68. Comparação entre o efeito do filtrado da cultura do fungo sob duas formas de cultivo e concentrações em meio seletivo quanto a sobrevivência das gemas que passaram por irradiação gama, após 6 semanas de cultivo.

\begin{tabular}{|c|c|c|c|c|c|c|c|c|}
\hline \multirow{2}{*}{$\begin{array}{l}\text { Modo de } \\
\text { Cultivo }\end{array}$} & \multicolumn{4}{|c|}{ Filtrado $55 \%$} & \multicolumn{4}{|c|}{ Filtrado $50 \%$} \\
\hline & Vivo & Morto & Total & Sel. (\%) & Vivo & Morto & Total & Sel.(\%) \\
\hline Co-cult. & 147 & 1.267 & 1.414 & 10,40 & 248 & 486 & 734 & 33,78 \\
\hline Normal & 43 & 1.007 & 1.050 & 4,10 & 478 & 441 & 919 & 52,01 \\
\hline Total & 190 & $\begin{array}{r}2.274 \\
\chi^{2}=33,\end{array}$ & $\begin{array}{l}2.464 \\
* \text { * g. I. }\end{array}$ & 7,71 & \multicolumn{4}{|c|}{$55,03^{* * *} ;$ g. I. $=1$} \\
\hline
\end{tabular}

${ }^{\star * \star}$ Significativo ao nível de $0,1 \%$ de probabilidade

Considerando que a concentração de filtrado da cultura foi a mais eficiente para a seleção de possíveis mutantes, observou-se que, nestas condições, o maior número de gemas sobreviventes por frasco e número de frascos com gemas sobreviventes foi inversamente proporcional à dose de radiação (Figura 27). A menor média, desconsiderando a dose de 30 Gy, foi observada à dose de 40 Gy (média de 2,53 gemas) e a maior, àdose de 10 Gy (Tabela 69). Este fato deve estar relacionado àseparação mais rápida do quimerismo dos tecidos quiméricos após os vários ciclos de multiplicação, em explantes onde irradiação afetou menos as células (doses menores), pois havendo menores danos ao DNA, mais facilmente é eliminado o quimerismo e conseqüentemente maior a probabilidade de obtenção de mutantes 
periclinais ou sólidos (Ahloowalia, 1998). Por isso, foi observado maior número de sobreviventes por frasco, considerando que todas as gemas das plantas foram submetidas ao processo de seleção.

Tabela 69. Efeito de filtrado do fungo à concentração de $55 \%$ na sobrevivência de gemas que sofreram irradiação gama após 6 semanas de cultivo.

\begin{tabular}{lccc}
\hline \multirow{2}{*}{ Dose (Gy) } & \multicolumn{3}{c}{ Gemas sobreviventes } \\
\cline { 2 - 4 } & Frascos/total & Amplitude & Média $\pm \mathrm{s}$ \\
\hline 10 & $25 / 55$ & $1-12$ & $4,92 \pm 2,96$ \\
20 & $6 / 13$ & $2-7$ & $4,00 \pm 1,79$ \\
30 & $0 / 5$ & 0 & $0,0 \pm 0,0$ \\
40 & $17 / 53$ & $1-9$ & $2,53 \pm 1,94$ \\
\hline
\end{tabular}

\subsubsection{Determinação da concentração de esporos e modo de inoculação}

A forma mais eficiente de infecção do fungo foi através da inoculação no solo, sendo que a concentração de $2 \times 10{ }^{6}$ esporos $/ \mathrm{ml}$ causou $100 \%$ de morte das plantas depois de seis meses (Figura 28). A inoculação por "spray" causou morte das plantas, mas ainda foram observadas sobreviventes. Inicialmente, os sintomas da doença apareceram cerca de um a dois meses após a inoculação do fungo, através de folhas com clorose, amareladas e por conseguinte necróticas. As folhas e o caule secaram e as plantas morreram cerca de seis meses após a inoculação, nas condições climáticas de Piracicaba, São Paulo, em casa-de-vegetação. Processo semelhante de seleção artificial foi utilizado por Ando et al. (1997) para seleção de plantas contra a fusariose com inoculação de suspensão de esporos do fungo no solo, na ordem de $4 \times 10^{5}$ esporos $/ \mathrm{ml}$.

Para o uso da radiação gama visando o melhoramento genético da pimentado-reino associado às técnicas in vitro, sugere-se a dose de 20 Gy em gemas de plantas propagadas in vitro, avanço de gerações por pelo menos três subcultivos para eliminação do quimerismo, seleção in vitro com filtrado da cultura do fungo Fusarium solani f. sp. piperis após 28 dias de cultivo em meio de cultura de Czapek-Dox na concentração de $55 \%(\mathrm{v} / \mathrm{v})$ sob a forma de esterilização por duas autoclavagens, micropropagação dos sobreviventes e seleções in vivo, em casa-de-vegetação, das 
mudas com seis meses de idade com aplicação no solo de $2 \times 10^{6}$ esporos $/ \mathrm{ml}$ do fungo e, finalmente, em campo em área de ocorrência da doença fusariose.

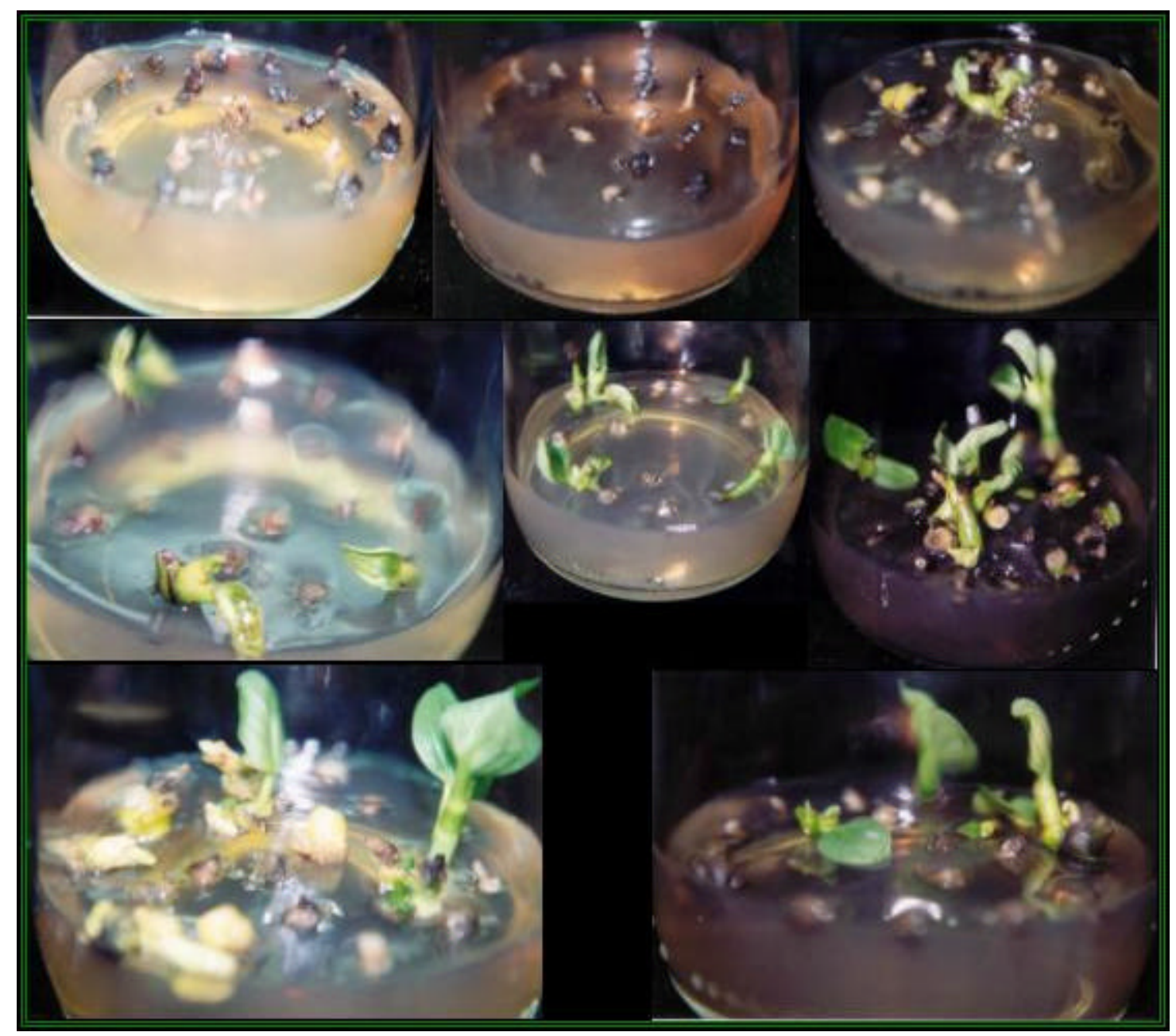

Figura 27 - Seleção in vitro de variantes originados por irradiação gama em gemas, sobreviventes ao agente seletivo filtrado da cultura do fungo Fusarium solanif. sp. piperis, após 6 semanas de cultivo. 


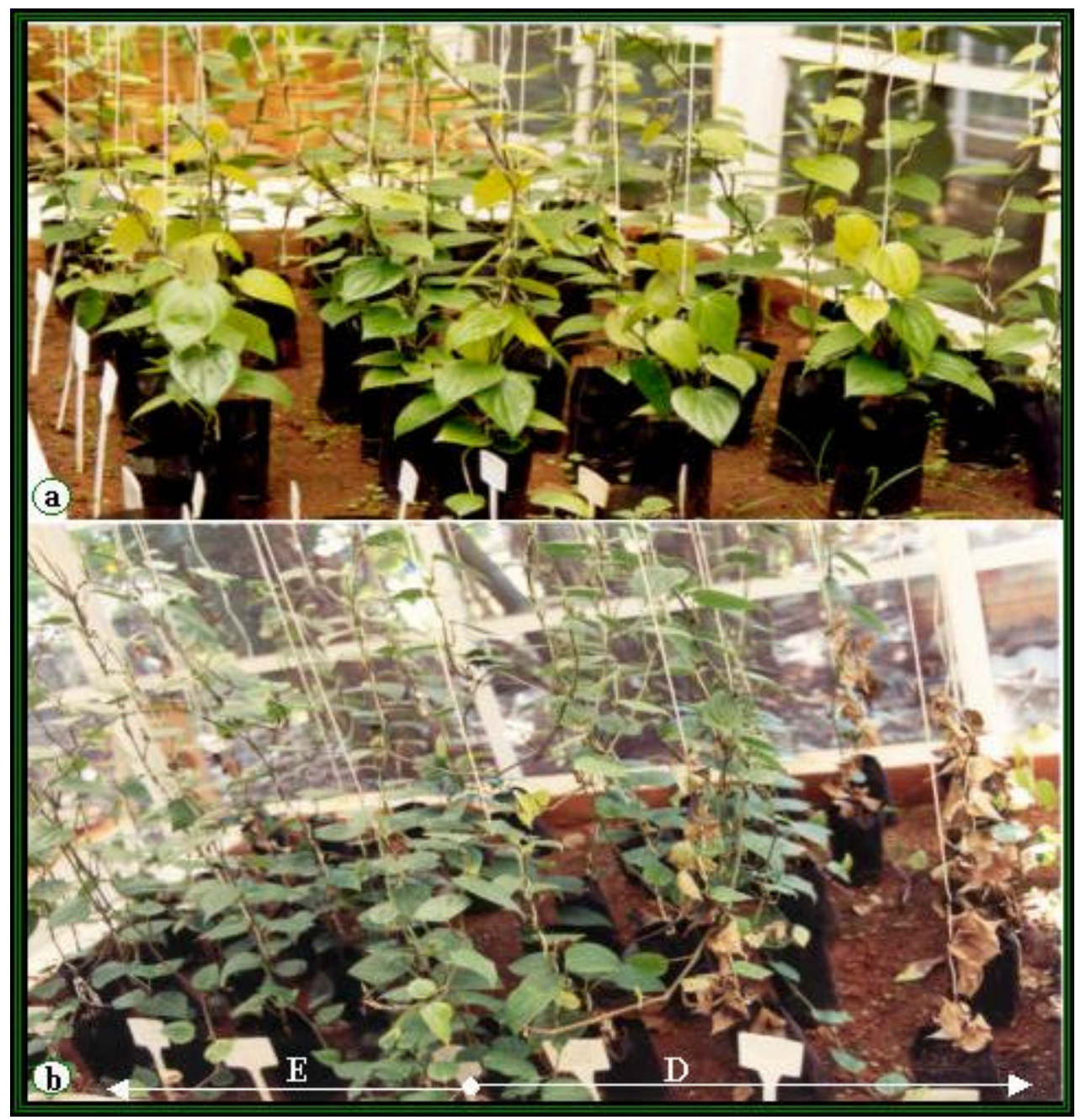

Figura 28 - Plantas submetidas àinoculação com esporos do fungo $\left(0 \mathrm{a} 2 \times 10^{2}, \times 10^{4} \mathrm{e}\right.$ $\times 10^{6}$ esporos $\left./ \mathrm{ml}\right)$.

a) Um mês após a inoculação

b) Seis meses após a inoculação: esquerda (E) via "spray" e direita (D) via solos 


\subsection{Avaliação agronômica de plantas oriundas de estacas tratadas com irradiação gama}

A seleção de três plantas $V_{2}$ sobreviventes a partir de 428 estacas $V_{1}$ irradiadas em 1978 permitiu, nos últimos 20 anos, avançar seis gerações. Durante todo esse processo, as plantas foram sendo cultivadas em área de ocorrência da doença fusariose e, através de seleção contínua de plantas com boa arquitetura, morfologia normal, e caracteres de produção favoráveis e sadias, avançou-se as gerações por meio de estaqueamento. A partir da quarta geração (plantas $V_{4}$ ), as mudas foram obtidas para formar linhagem. Estas linhagens foram plantadas em área de ocorrência da doença para avaliação agronômica, baseada nos caracteres de produção, e mortalidade e sobrevivência devido a incidência da doença (Figura 29).

Observou-se performance em caracteres de produção, tanto das linhagens de plantas $V_{5}$ cultivadas na propriedade do $\mathrm{Sr}$. Inada, um produtor de pimenta-do-reino em Tomé-Açu, Pará, quanto das plantas $V_{6}$ cultivadas na área da ASFATA, sendo que das linhagens das plantas $V_{5}$ identificou-se a mortalidade e sobrevivência das plantas em quatro anos consecutivos sob condições de incidência da doença fusariose e de outros fatores adversos, tais como seca, excesso de água no solo, etc.

\subsubsection{Avaliação agronômica das linhagens de plantas $V_{5}$}

Pelas avaliações realizadas até o ano 2000, observou-se que, das linhagens que se constituíram de três ou mais repetições, destacaram-se C25, C45, C132 e C170 por apresentarem menores índices de morte pela ńcidência da doença fusariose. Porém, outros fatores, como a seca e excesso de água no solo, afetaram mais a sobrevivência das linhagens originadas das estacas irradiadas $V_{1}$ do que daquelas não irradiadas (Tabela 70). Ressalte-se que inicialmente, a morte por incidência da fusariose foi menor (19,3\%) nas linhagens originadas de estacas irradiadas do que não irradiadas (47,4\%). Em princípio, o efeito da radiação gama e a seleção para tolerância à doença fusariose foi favorável a maior sobrevivência das plantas em área de ocorrência do fungo. 


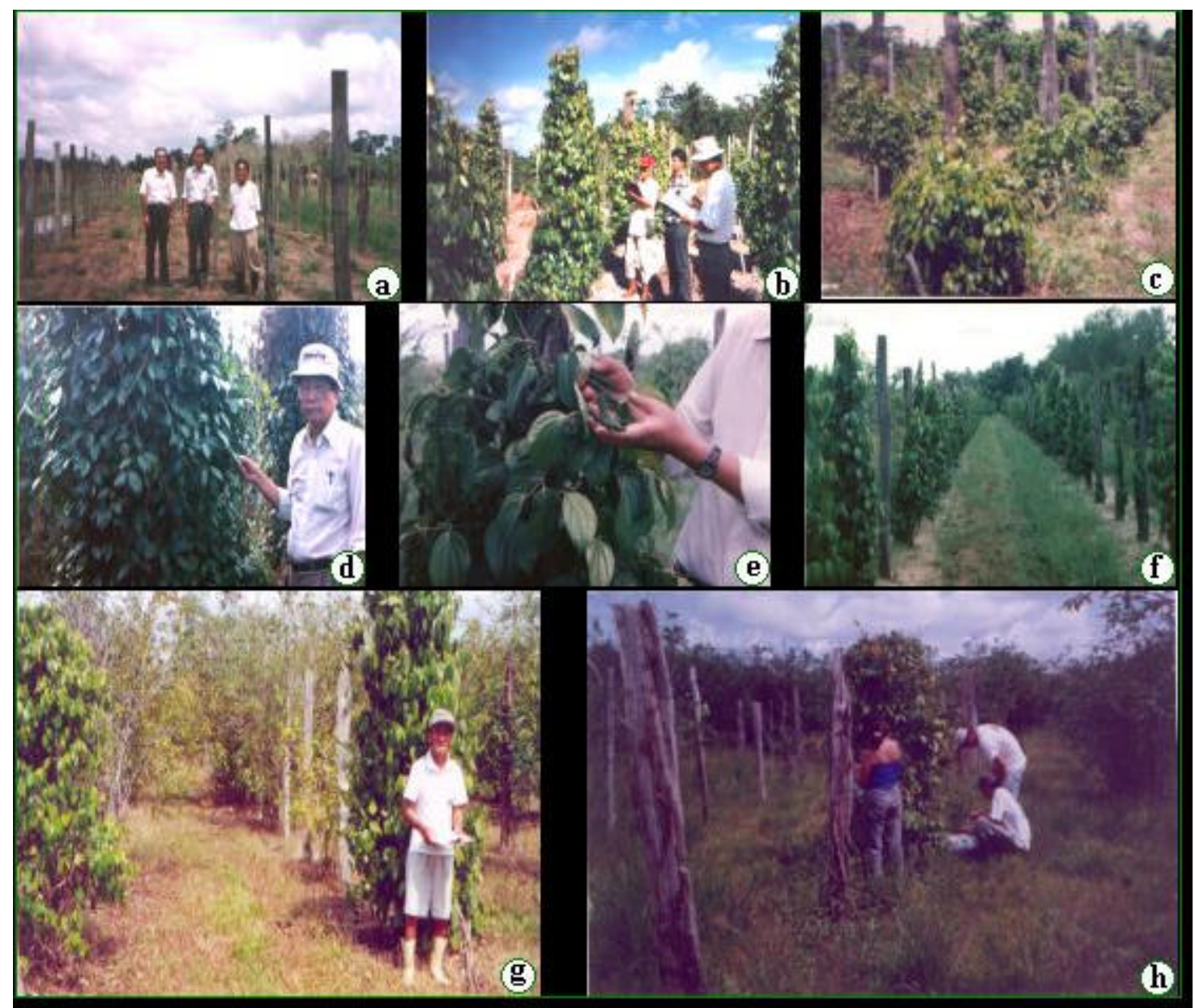

Figura 29 - Desenvolvimento e avaliação de plantas originadas a partir de estacas irradiadas.

a) Implantação do experimento em área de ocorrência da doença fusariose

b Avaliação quanto as características morfológicas

c) Podas para avanço de geração

d-e) Seleção de plantas individuais com boa arquitetura e formação de espigas

f) Área com plantas $V_{5}$ após um ano

g) Área com plantas $V_{5}$ após seis anos

h) Planta $V_{5}$ sobrevivente após sete anos de cultivo e avaliadas quanto aos caracteres de produção 
Tabela 70. Incidência da doença fusariose e sobrevivência de plantas.

\begin{tabular}{lccrrrr}
\hline Linhagem $^{1}$ & $\begin{array}{c}\text { Total } \\
\text { de } \\
\text { Plantas }\end{array}$ & Repetição & \multicolumn{2}{c}{$\begin{array}{c}\text { Plantas sobreviventes } \\
(\%)\end{array}$} & \multicolumn{2}{c}{$\begin{array}{c}\text { Plantas mortas pela } \\
\text { fusariose }(\%)\end{array}$} \\
\cline { 3 - 7 } & & \multicolumn{1}{c}{1999} & 2000 & 1999 & \multicolumn{1}{c}{2000} \\
\hline C25 & 22 & 3 & $7(31,8)$ & $7(31,8)$ & $1(6,7)$ & $1(6,7)$ \\
C26 & 40 & 5 & $18(45,0)$ & $12(30,0)$ & $2(9,1)$ & $8(28,6)$ \\
C45 & 24 & 3 & $7(29,2)$ & $6(25,0)$ & $1(5,9)$ & $1(11,1)$ \\
C70 & 56 & 7 & $29(51,8)$ & $19(33,9)$ & $0(0,0)$ & $9(24,3)$ \\
C123 & 40 & 5 & $19(47,5)$ & $15(37,5)$ & $1(4,8)$ & $4(16,0)$ \\
C132 & 24 & 3 & $9(37,5)$ & $8(33,3)$ & $0(0,0)$ & $0(0,0)$ \\
C137 & 24 & 3 & $13(54,2)$ & $10(41,7)$ & $1(9,1)$ & $3(21,4)$ \\
C163 & 56 & 7 & $23(41,1)$ & $12(21,4)$ & $3(9,1)$ & $11(25,0)$ \\
C166 & 56 & 7 & $19(33,9)$ & $11(19,6)$ & $4(10,8)$ & $11(24,4)$ \\
C170 & 48 & 6 & $18(37,5)$ & $15(31,3)$ & $0(0,0)$ & $3(9,1)$ \\
N27 & 8 & 1 & $4(50,0)$ & $4(50,0)$ & $1(25,0)$ & $1(25,0)$ \\
N108 & 16 & 2 & $7(43,8)$ & $5(31,3)$ & $1(11,1)$ & $3(27,3)$ \\
N121 & 8 & 1 & $5(62,5)$ & $3(37,5)$ & $0(0,0)$ & $2(66,7)$ \\
N135 & 8 & 1 & $4(50,0)$ & $3(37,5)$ & $0(0,0)$ & $1(25,0)$ \\
N148 & 8 & 1 & $3(37,5)$ & $3(37,5)$ & $0(0,0)$ & $0(0,0)$ \\
& & & & & & \\
Total & 438 & & $185(42,2)$ & $133(30,4)$ & $15(5,9)$ & $59(19,3)$ \\
CT & 24 & 3 & $13(54,2)$ & $5(20,8)$ & $2(18,2)$ & $9(47,4)$ \\
\hline
\end{tabular}

Linhagens selecionadas de estacas irradiadas a partir do viveiro da CAMTA $\left(\mathrm{C}_{n}\right)$, a partir do viveiro da Fazenda Nakanishi $\left(\mathrm{N}_{n}\right)$, e a partir de estacas não irradiadas (CT), em Tomé-Açu, Pará

A floração das plantas foi muito variável tanto ras plantas $V_{5}$ de todas as linhas quanto nas plantas testemunha da cultivar Cingapura (CT). Segundo informações do produtor, o fenômeno teve início em meados de novembro, logo que ocorreram as primeiras chuvas, e estendeu-se até março. O comportamento das linhagens selecionadas e testemunha foi semelhante, sendo um caráter muito influenciado pelas chuvas. Em janeiro de 2002, 93,55\% das plantas apresentavam florescimento e, em final de fevereiro, todas.

A frutificação também foi variável, iniciando-se seis meses após o início da floração, que foi verificada desde final de maio até setembro, sendo o pico em agosto, quando a maioria das espigas apresentou os frutos de coloração amarelada a avermelhada, situação comum na região para a cultura de pimenta-do-reino, segundo Poltronieri et al. (1999).

Os caracteres de produção avaliados em 2000 apresentaram variação quanto aos aspectos da espiga (Tabela 70). O comprimento variou de 6,60 a 9,28cm (C163 e C26, respectivamente) com média de 7,91 cm; peso de 3,053 a 5,870 g (C163 e C70, respectivamente) com média de 4,589 g; e número de frutos de 27,3 a 49,6 por espiga 
(C163 e C70, respectivamente) e média de 38,1 frutos. Quanto ao peso de 100 frutos, variou-se de 8,66g (N108) a 14,84g (C137), com a média 11,61 g; enquanto para o caráter produção média por planta, a linhagem C45 apresentou menor produção $(1.540,0 \mathrm{~g})$ e a linhagem N135 maior produção $(8.900,0 \mathrm{~g})$. A Figura 30 mostra que a amplitude de variação quanto ao comprimento e peso da espiga, e peso de 100 frutos é pequena, enquanto a amplitude de variação de número de frutos por espiga é mais proeminente. A média geral de produção por planta nas linhagens mutantes foi de $3.912,50 \mathrm{~g}$, enquanto nas plantas utilizadas como testemunha (CT), cultivar tradicional Cingapura, a média por planta foi de 2.700,0 g (Figura 31).

As plantas $V_{5}$ apresentaram melhor performance que as plantas da cultivar Cingapura, o que evidenciou que em área infestada pela doença respondem mais favoravelmente às condições adversas de cultivo.

Tabela 71. Características da espiga, peso de 100 frutos e produção média por planta de pimenta verde das linhagens $V_{5}$ após seis anos de cultivo.

\begin{tabular}{|c|c|c|c|c|c|}
\hline \multirow[t]{2}{*}{ Linhagem } & \multicolumn{3}{|c|}{ Espiga $^{1}$} & \multirow{2}{*}{$\begin{array}{l}\text { Peso de } 100 \\
\text { frutos }(\mathrm{g})\end{array}$} & \multirow{2}{*}{$\begin{array}{l}\text { Produção (g) } \\
\text { média/planta }\end{array}$} \\
\hline & Comp.(cm) & Peso (g) & Frutos & & \\
\hline C26 & 9,28 & 4,197 & 43,0 & 10,68 & $4.661,11$ \\
\hline C132 & 7,85 & 4,842 & 32,6 & 12,36 & $3.650,00$ \\
\hline C166 & 8,03 & 3,874 & 32,5 & 12,45 & $4.521,43$ \\
\hline N135 & 8,42 & 5,054 & 43,6 & 10,79 & $8.900,00$ \\
\hline C70 & 8,79 & 5,870 & 49,6 & 12,07 & $4.258,89$ \\
\hline N148 & 7,33 & 4,686 & 42,8 & 8,80 & $2.925,00$ \\
\hline C25 & 7,94 & 4,581 & 35,5 & 10,52 & $3.000,00$ \\
\hline C45 & 6,90 & 4,624 & 33,7 & 14,40 & $1.540,00$ \\
\hline $\mathrm{N} 1 \mathrm{~A}$ & 7,47 & 4,897 & 39,3 & 10,55 & $5.400,00$ \\
\hline C163 & 6,60 & 3,053 & 27,3 & 12,52 & $3.072,22$ \\
\hline C123 & 7,70 & 4,759 & 41,8 & 10,47 & $4.629,17$ \\
\hline N121 & 9,07 & 5,614 & 45,4 & 12,44 & $3.950,00$ \\
\hline C170 & 8,72 & 4,758 & 31,8 & 13,90 & $2.722,22$ \\
\hline C137 & 7,36 & 4,087 & 34,8 & 14,84 & $2.566,67$ \\
\hline N27 & 7,68 & 4,321 & 36,4 & 10,33 & $3.203,33$ \\
\hline N108 & 7,49 & 4,206 & 39,3 & 8,66 & $3.600,00$ \\
\hline Média Geral & 7,91 & 4,589 & 38,1 & 11,61 & $3.912,50$ \\
\hline
\end{tabular}

Média a partir de 10 espigas 


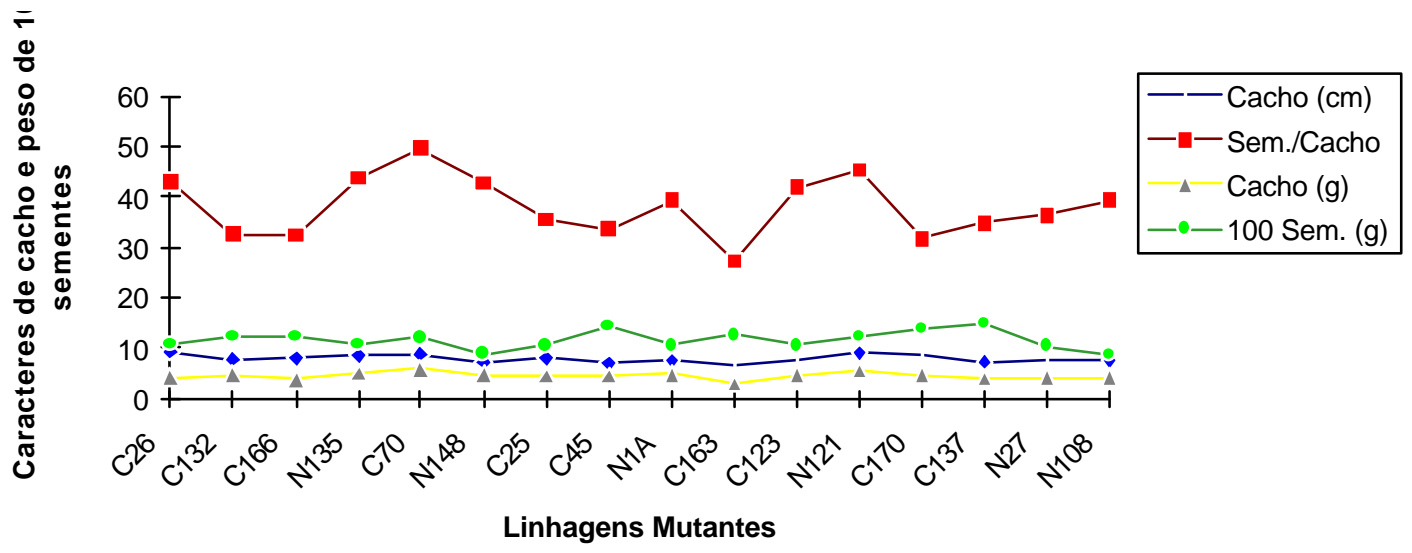

Figura 30 - Performance de caracteres de produção de pimenta-do-reino de 16 linhagens $V_{5}$ após seis anos de cultivo.

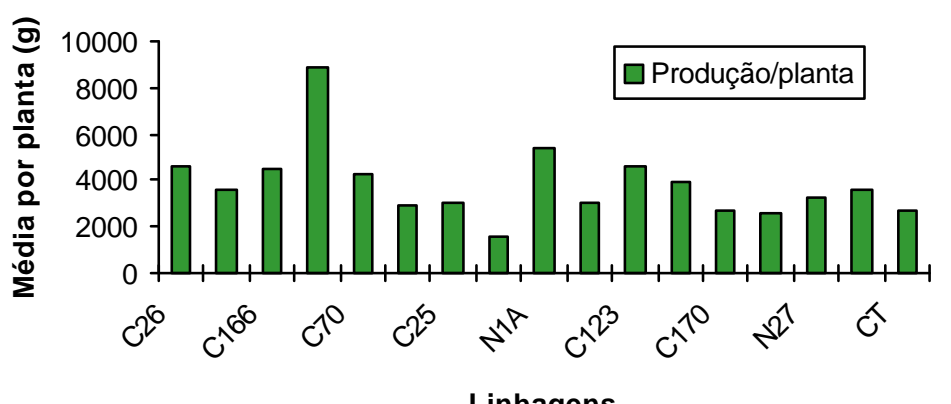

Figura 31 - Performance de produção de pimenta-do-reino de 16 linhagens $V_{5}$ originadas de estacas irradiadas com raios-gama e uma linhagem testemunha (CT) após seis anos de cultivo.

$\mathrm{Na}$ avaliação durante três anos consecutivos de caracteres de espiga, as médias para os diferentes caracteres variaram de 6,6 a 10,49cm para comprimento da espiga, 2,95 a 5,87g para peso da espiga e 23 a 54 frutos por espiga (Tabela 72 e Figura 32), cujas linhagens de plantas $V_{5}$ podem ser consideradas de baixo a médio em comprimento de espiga $(6,35-8,60 \mathrm{~cm}$ e $8,61-11,17 \mathrm{~cm}$, respectivamente) e médio em número de frutos por espiga (26-59 frutos), segundo o critério de Mathew et al. 
(2001). Estes aspectos indicaram que houve poucas alterações em linhagens $V_{5}$ nestas características em relação a cultivar original, haja vista que apresenta baixo comprimento de espiga e médio número de frutos por espiga.

Tabela 72. Características da inflorescência (espiga) quanto ao comprimento, peso e número de frutos, avaliadas durante três anos consecutivos de produção.

\begin{tabular}{lcccccccccc}
\hline \multirow{2}{*}{ Linhagem } & \multicolumn{7}{c}{ Inflorescência (espiga) } \\
\cline { 2 - 10 } & \multicolumn{3}{c}{ Comprimento (cm) } & \multicolumn{7}{c}{ Peso (g) } \\
\cline { 2 - 10 } & 2000 & 2001 & 2002 & 2000 & 2001 & 2002 & 2000 & 2001 & 2002 \\
\hline CT & - & - & 6,30 & & - & 0,87 & - & - & 4,20 \\
N1A & 7,47 & 9,86 & & 4,90 & 4,78 & & 39,3 & 53,80 & - \\
C25 & 7,94 & 8,79 & & 4,58 & 3,78 & & 35,5 & 38,85 & - \\
C26 & 9,28 & 9,32 & 7,42 & 4,20 & 5,19 & 4,24 & 43,0 & 51,60 & 41,70 \\
N27 & 7,68 & 10,09 & 8,12 & 4,32 & 4,53 & 4,40 & 36,4 & 47,45 & 41,80 \\
C45 & 6,90 & 9,35 & 8,22 & 4,62 & 5,08 & 4,51 & 33,7 & 48,50 & 45,30 \\
C70 & 8,79 & 9,57 & 7,37 & 5,87 & 5,35 & 4,14 & 49,6 & 48,96 & 35,70 \\
N108 & 7,49 & - & - & 4,21 & - & - & 39,3 & & - \\
N121 & 9,07 & - & - & 5,61 & - & - & 45,4 & & - \\
C123 & 7,70 & 9,41 & 8,26 & 4,76 & 5,05 & 4,84 & 41,8 & 53,24 & 44,85 \\
C132 & 7,85 & 9,47 & & 4,84 & 4,65 & - & 32,6 & 43,38 & - \\
N135 & 8,42 & & - & 5,05 & & - & 43,6 & - & - \\
C137 & 7,36 & 9,47 & 7,11 & 4,09 & 4,74 & 3,72 & 34,8 & 50,95 & 32,70 \\
N148 & 7,33 & 8,52 & 7,63 & 4,69 & 3,61 & 3,56 & 42,8 & 42,93 & 31,90 \\
C163 & 6,6 & 10,49 & 8,14 & 3,05 & 5,60 & 2,95 & 27,3 & 51,10 & 23,05 \\
C166 & 8,03 & 9,09 & 8,48 & 3,87 & 4,05 & 4,73 & 32,5 & 44,08 & 36,30 \\
C170 & 8,72 & 9,61 & 8,05 & 4,76 & 4,96 & 3,25 & 31,8 & 43,15 & 25,85 \\
Média & 7,91 & 9,46 & 7,74 & 4,59 & 4,72 & 3,75 & 38,09 & 47,54 & 33,038 \\
\hline
\end{tabular}

Outrossim, foi observado que a média de peso de 100 frutos úmidos variou de 7,73 a 13,90 g, sendo portanto consideradas plantas médio em peso de 100 frutos. Quanto a produção aos seis (ano 2000) e sete anos (ano 2001) de cultivo, mostrou-se estabilidade (média superior a $4.000 \mathrm{~g}$ ), mas ao oitavo ano de cultivo (ano 2002) apresentou-se uma queda vertiginosa (Tabela 73). 
Tabela 73. Peso úmido de 100 frutos e produção das linhagens de plantas $V_{5}$ avaliadas em três anos consecutivos de produção.

\begin{tabular}{lcccccc}
\hline \multirow{2}{*}{ Linhagens } & \multicolumn{3}{c}{ Peso de 100 frutos $(\mathrm{g})$} & \multicolumn{3}{c}{ Produção $(\mathrm{g})$} \\
\cline { 2 - 7 } & 2000 & 2001 & 2002 & 2000 & 2001 & 2002 \\
\hline CT & - & - & - & $2.700,0$ & - & - \\
N1A & 10,55 & 8,34 & - & $5.400,0$ & 3.200 & - \\
C25 & 10,52 & 8,51 & - & $3.000,0$ & 500 & - \\
C26 & 10,68 & 8,81 & 10,13 & $4.661,1$ & 7.400 & 1.800 \\
N27 & 10,33 & 8,90 & 10,79 & $3.203,3$ & 5.500 & 1.400 \\
C45 & 14,40 & 9,36 & 10,81 & $1.540,0$ & 3.350 & 800 \\
C70 & 12,07 & 8,09 & 11,48 & $4.258,9$ & 5.700 & 2.000 \\
N108 & 8,66 & - & - & $3.600,0$ & - & - \\
N121 & 12,44 & - & - & $3.950,0$ & - & - \\
C123 & 10,47 & 8,72 & 10,13 & $4.629,2$ & 5.940 & 900 \\
C132 & 12,36 & 9,05 & - & $3.650,0$ & 7.300 & - \\
N135 & 10,79 & - & - & $8.900,0$ & - & - \\
C137 & 14,84 & 8,39 & 11,85 & $2.556,7$ & 3.500 & 1.800 \\
N148 & 8,80 & 7,73 & 10,87 & $2.925,0$ & 2.100 & 750 \\
C163 & 12,52 & 9,23 & 11,71 & $3.072,2$ & 5.050 & 1.575 \\
C166 & 12,45 & 8,38 & 12,58 & $4.521,4$ & 3.267 & 2.700 \\
C170 & 13,90 & 9,59 & 11,99 & $5.796,4$ & 4.892 & 1.100 \\
& & & & & & \\
Média & 11,61 & 8,70 & 11,23 & $4.104,02$ & 4.438 & $1.482,50$ \\
\hline
\end{tabular}

Como se observa nos gráficos (Figura 32), nos três anos consecutivos houve maior variação para os caracteres de produção de pimenta verde, seguido de número de frutos por espiga, enquanto para comprimento e peso da espiga e peso de 100 frutos, a variação foi pequena. A grande variação para número de frutos por espiga e produção está muito relacionada à polinização das flores, que é muito dependente da chuva, mas não em intensidade e sim em qualidade, uma vez que o orvalho e chuvas leves proporcionam alta umidade (superior a $80 \%$ ) que são favoráveis à polinização, segundo Nambiar et al. (1978). 

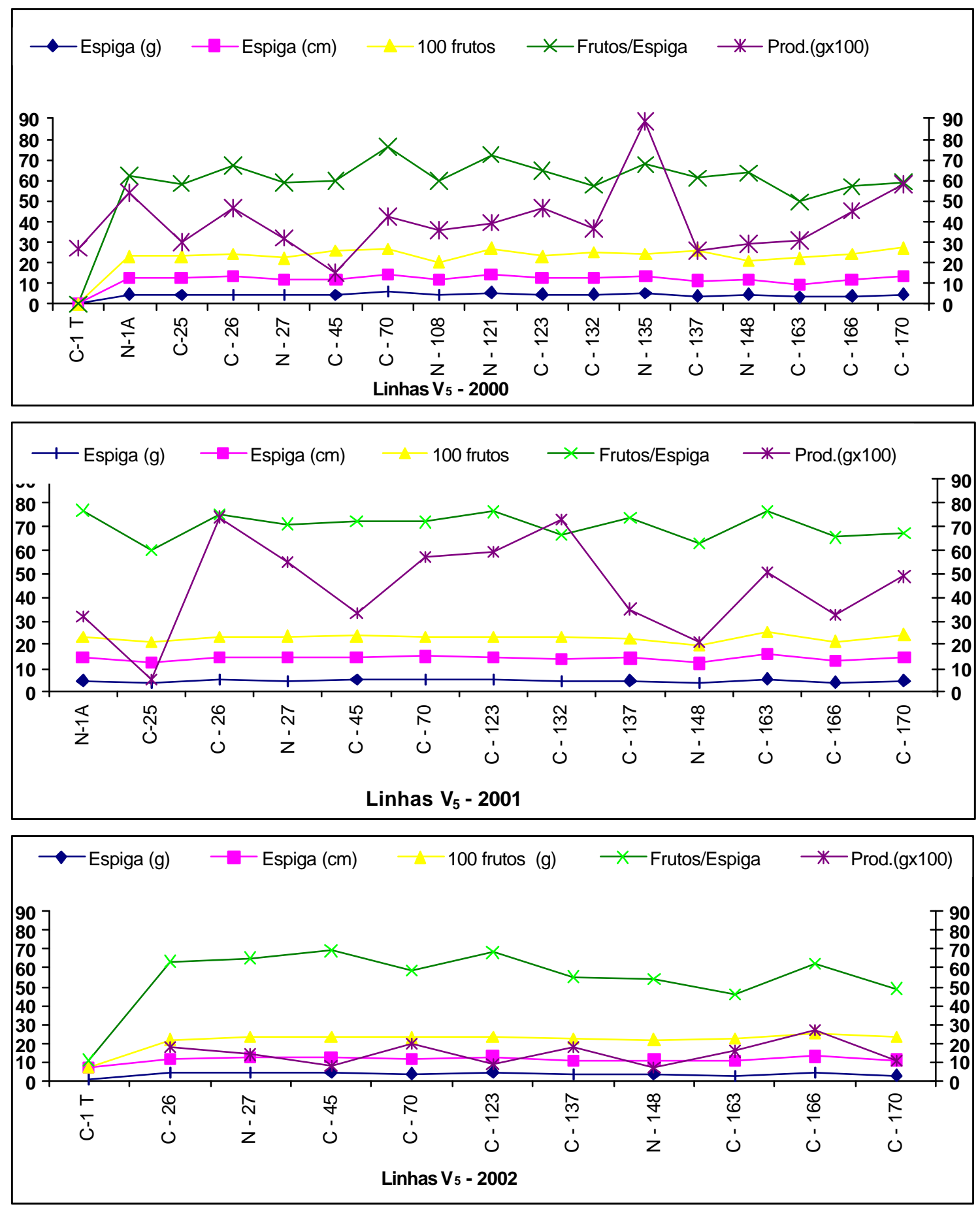

Figura 32 - Performance das linhagens $V_{5}$ durante três anos consecutivos quanto aos caracteres de produção. 
O teste Tukey para a comparação de médias dos diferentes caracteres de produção das plantas das linhagens $V_{5}$ não apresentou diferença significativa para todos os caracteres avaliados. Isto demonstra que as diferenças entre as linhagens para os caracteres envolvidos foram normais e plenamente aceitáveis como semelhantes entre si, sugerindo que a irradiação das estacas afetou pouco essas características. Na variação de espiga, peso de 100 frutos e produção por planta, detectou-se uma amplitude grande entre os caracteres avaliados, desde 6,63 g para peso da espiga, seguido de $7,7 \mathrm{~cm}$ para comprimento, 57 frutos por espiga até $4,69 \mathrm{~g}$ para peso de 100 frutos e $7.485 \mathrm{~g}$ para a produção por planta, cujas médias foram respectivamente 4,42 g; 8,4 cm; 40,5 frutos; 10,67 g e $3.290 \mathrm{~g}$ (Tabela 74).

Tabela 74. Variação quanto aos diferentes caracteres de produção e média de três anos das linhagens que apresentaram sobreviventes após oito anos de cultivo em área de ocorrência da doença fusariose em pimenta-do-reino.

\begin{tabular}{|c|c|c|c|c|c|c|c|c|c|c|}
\hline \multirow{3}{*}{ Linh. } & \multicolumn{6}{|c|}{ Espiga } & \multirow{2}{*}{\multicolumn{2}{|c|}{$\begin{array}{l}\text { Peso de } 100 \\
\text { frutos }\end{array}$}} & \multirow{2}{*}{\multicolumn{2}{|c|}{ Produção (g) }} \\
\hline & \multicolumn{2}{|c|}{ Peso (g) } & \multicolumn{2}{|c|}{ Comp.(cm) } & \multicolumn{2}{|c|}{ Frutos } & & & & \\
\hline & Var. & $\mathrm{M}^{\top}$ & Var. & $M^{\prime}$ & Var. & $\mathrm{M}^{1}$ & Var. & $\mathrm{M}^{+}$ & Var. & $\mathrm{M}^{\prime}$ \\
\hline C26 & $1,89-7,12$ & 4,54 & $4,6-12,0$ & 8,7 & $15-72$ & 45,4 & $8,21-10,68$ & 9,87 & $1800-12100$ & 4620 \\
\hline N27 & $1,61-8,38$ & 4,42 & $5,9-13,5$ & 8,6 & $16-71$ & 41,9 & $8,79-10,79$ & 10,01 & $1400-6000$ & 3368 \\
\hline C45 & $1,48-9,10$ & 4,74 & $4,8-12,3$ & 8,2 & $18-72$ & 42,5 & $8,17-14,4$ & 11,52 & $500-4600$ & 1897 \\
\hline $\mathrm{C} 70$ & $2,58-8,66$ & 5,12 & $6,3-12,8$ & 8,6 & $23-73$ & 44,8 & $7,56-12,07$ & 10,55 & $1000-7800$ & 3986 \\
\hline C123 & $1,68-9,22$ & 4,88 & $5,0-13,0$ & 8,5 & $18-72$ & 46,6 & $5,88-11,21$ & 9,77 & $1350-10400$ & 3823 \\
\hline C137 & $1,04-8,66$ & 4,18 & $5,0-12,9$ & 8,0 & $12-76$ & 39,5 & $6,92-14,84$ & 11,69 & $300-6100$ & 2619 \\
\hline N148 & $1,55-7,46$ & 3,95 & $4,6-13,0$ & 7,8 & $19-72$ & 39,2 & $6,46-10,87$ & 9,13 & $750-4400$ & 1925 \\
\hline C163 & $0,98-6,99$ & 3,87 & $5,3-14,0$ & 8,4 & 7-76 & 33,8 & $8,19-12,52$ & 11,15 & $650-7700$ & 3232 \\
\hline C166 & $1,34-6,39$ & 4,22 & $5,8-11,3$ & 8,5 & $24-70$ & 37,6 & $8,26-12,58$ & 11,14 & $1700-11500$ & 3496 \\
\hline C170 & $1,19-9,65$ & 4,32 & $4,3-14,5$ & 8,8 & 7-78 & 33,6 & $8,56-13,90$ & 11,83 & $700-14400$ & 3929 \\
\hline Média & $1,53-8,16$ & 4,42 & $5,2-12,9$ & 8,4 & $16-73$ & 40,5 & $7,70-12,39$ & 10,67 & $1015-8500$ & 3290 \\
\hline
\end{tabular}

'Média de três anos de avaliação, teste Tukey para comparação de médias entre as linhagens não apresentou diferença significativa

Quanto a sobrevivência e mortalidade, principalmente pela incidência da doença fusariose, em quatro anos de avaliações, observou-se que a partir de cinco anos de cultivo, em área de ocorrência da doença, o índice de mortalidade alcançou a 
média de $57,08 \%$, variando de $37,50 \%$ (N121) a $78,13 \%$ (C45) em quinto ano de cultivo em 1999, e as médias de 70,42\%, 85,42\% e $97,08 \%$, no sexto, sétimo e oitavo ano de cultivo, respectivamente (Tabela 75). Ressalte-se que a processo contínuo de seleção (cinco ciclos de avanço de geração) levou a uma maior tolerância das plantas à doença, pois após oito anos de cultivo, ainda, havia plantas sobreviventes (Figura 33). Segundo a observação de Albuquerque et al. (1991), a plantação é totalmente dizimada ao sexto ano.

Tabela 75. Performance das linhas $V_{5}$ no período de 1994 a 2002 quanto a mortalidade e sobrevivência das plantas.

\begin{tabular}{|c|c|c|c|c|c|c|}
\hline \multirow[t]{2}{*}{ Linha } & \multirow{2}{*}{$\begin{array}{c}\text { Plantas em } \\
1994\end{array}$} & \multicolumn{4}{|c|}{ Mortalidade (\%) } & \multirow[t]{2}{*}{ Sobrevivente $^{2}$} \\
\hline & & $1999^{1}$ & 2000 & 2001 & 2002 & \\
\hline CT & 24 & $11(45,83)$ & $19(79,17)$ & $21(87,50)$ & $23(95,83)$ & $1(4,17)$ \\
\hline N1A & 16 & $12(75,00)$ & $13(81,25)$ & $15(93,75)$ & $16(100,0)$ & $0(0,00)$ \\
\hline C25 & 24 & $17(70,83)$ & $17(70,83)$ & $21(87,50)$ & $24(100,0)$ & $0(0,00)$ \\
\hline C26 & 40 & $22(55,00)$ & $28(70,00)$ & $36(90,00)$ & $39(97,50)$ & $1(2,50)$ \\
\hline N27 & 8 & $4(50,00)$ & $4(50,00)$ & $6(75,00)$ & $7(87,50)$ & $1(12,50)$ \\
\hline $\mathrm{C} 45$ & 32 & $25(78,13)$ & $26(81,25)$ & $28(87,50)$ & $31(96,88)$ & $1(3,12)$ \\
\hline C70 & 56 & $27(48,21)$ & $37(66,07)$ & $50(89,29)$ & $55(98,21)$ & $1(1,79)$ \\
\hline N108 & 16 & $9(56,25)$ & $11(68,75)$ & $15(93,75)$ & $16(100,0)$ & $0(0,00)$ \\
\hline N121 & 8 & $3(37,50)$ & $5(62,50)$ & $8(100,0)$ & $8(100,0)$ & $0(0,00)$ \\
\hline C123 & 40 & $21(52,50)$ & $25(62,50)$ & $30(75,00)$ & $38(95,00)$ & $2(5,00)$ \\
\hline C132 & 24 & $14(58,33)$ & $16(66,67)$ & $18(75,00)$ & $24(100,0)$ & $0(0,00)$ \\
\hline N135 & 8 & $4(50,00)$ & $5(62,50)$ & $8(100,0)$ & $8(100,0)$ & $0(0,00)$ \\
\hline C137 & 24 & $11(45,83)$ & $14(58,33)$ & $17(70,83)$ & $23(95,83)$ & $1(4,17)$ \\
\hline N148 & 8 & $5(62,50)$ & $5(62,50)$ & $6(75,00)$ & $7(87,50)$ & $1(12,50)$ \\
\hline C163 & 56 & $32(57,14)$ & $43(76,79)$ & $49(87,50)$ & $54(96,43)$ & $2(3,57)$ \\
\hline C166 & 48 & $29(60,42)$ & $37(77,08)$ & $43(89,58)$ & $47(97,92)$ & $1(2,08)$ \\
\hline C170 & 48 & $30(62,50)$ & $33(68,75)$ & $39(81,25)$ & $46(95,83)$ & $2(4,17)$ \\
\hline Total & 480 & $274(57,08)$ & $338(70,42)$ & $410(85,42)$ & $466(97,08)$ & $14(2,92)$ \\
\hline
\end{tabular}

TMortalidade a partir do plantio em março de 1994 a 1999

${ }^{2}$ Após oito anos de cultivo em área de ocorrência da doença 


\begin{tabular}{|c|c|c|c|c|c|c|c|c|c|c|c|c|c|c|c|c|c|c|}
\hline $\mathbf{X}$ & $\mathbf{X}$ & & $\mathbf{X}$ & & $\mathbf{X}$ & & $\mathbf{X}$ & & $\mathbf{X}$ & & $\mathbf{X}$ & & $\mathbf{X}$ & & $\mathbf{X}$ & $\mathbf{X}$ & $\mathbf{X}$ & $\mathbf{X}$ \\
\hline $\mathbf{X}$ & $\mathbf{X}$ & & $\mathbf{X}$ & & $\mathbf{X}$ & & $\mathbf{X}$ & & $\mathbf{X}$ & & $\mathbf{X}$ & & $\mathbf{X}$ & & $\mathbf{X}$ & $\mathbf{X}$ & $\mathbf{X}$ & $\mathbf{X}$ \\
\hline $\mathbf{X}$ & $\mathbf{X}$ & & $\mathbf{X}$ & & $\mathbf{X}$ & & $\mathbf{X}$ & & $\mathbf{X}$ & & $\mathbf{X}$ & & $\mathbf{X}$ & & $\mathbf{X}$ & $\mathbf{X}$ & $\mathbf{X}$ & $\mathbf{X}$ \\
\hline O & $\mathbf{O}$ & & $\mathbf{O}$ & & $\mathbf{O}$ & & 0 & & O & & O & & O & & 0 & $\mathbf{O}$ & $\mathbf{O}$ & 0 \\
\hline O & O & & O & & O & & O & & O & & O & & O & & $\mathbf{O}$ & O & O & O \\
\hline O & O & & O & & $\mathbf{O}$ & & O & & O & & O & & O & & $\mathbf{O}$ & O & O & $\mathbf{O}$ \\
\hline O & 0 & & O & & O & & 0 & & O & & O & & O & & $\mathbf{O}$ & 0 & O & $\mathbf{O}$ \\
\hline O & O & & O & & O & & O & & 0 & & O & & O & & O & O & O & 0 \\
\hline O & $\mathbf{O}$ & & O & & O & & O & & O & & O & & O & & O & O & $\mathbf{O}$ & O \\
\hline O C-3 & $\mathbf{O}$ & C-2 & O & C-3 & O & C-3 & O & C-3 & O & C-1 & O & C-3 & O I & N-1 & $\mathbf{C - 3}$ & O N-3 & O C-1 & OC-1 \\
\hline O 70 & O & 45 & O & 170 & O & 123 & O & 132 & O 1 & 163 & O & $\mathbf{T}$ & O & A & O 166 & O 148 & O 137 & 025 \\
\hline $\mathbf{X}$ & $\mathbf{X}$ & & $\mathbf{X}$ & & $\mathbf{X}$ & & $\mathbf{X}$ & & $\mathbf{X}$ & & $\mathbf{X}$ & & $\mathbf{X}$ & & $\mathbf{X}$ & $\mathbf{X}$ & $\mathbf{X}$ & $\mathbf{X}$ \\
\hline O & $\mathbf{O}$ & & O & & $\mathbf{O}$ & & O & & O & & 0 & & O & & $\mathbf{O}$ & $\mathbf{O}$ & $\mathbf{O}$ & $\mathbf{O}$ \\
\hline O & O & & O & & O & & O & & O & & O & & O & & O & $\mathbf{O}$ & O & O \\
\hline O & O & & O & & O & & 0 & & O & & O & & O & & $\mathbf{O}$ & O & O & O \\
\hline O & O & & O & & 0 & & O & & 0 & & O & & 0 & & O & O & O & O \\
\hline O & $\mathbf{O}$ & & O & & O & & O & & O & & O & & 0 & & O & O & $\mathbf{O}$ & O \\
\hline O & O & & O & & O & & O & & $\mathbf{O}$ & & O & & O & & $\mathbf{O}$ & $\mathbf{O}$ & O & O \\
\hline O C-3 & O & C-2 & O & C-1 & O & C-3 & O & C-1 & O & C-1 & O & C-3 & O I & $\mathrm{N}-2$ & $\mathbf{N - 2}$ & $\mathbf{C - 1}$ & O C-1 & $\mathrm{ON}-1$ \\
\hline 123 & O & 45 & O & 26 & O & 163 & O & 26 & 01 & 123 & 0 & 26 & O 1 & 108 & O 27 & $\begin{array}{ll}\mathbf{O} & \mathbf{T}\end{array}$ & O 132 & $\mathbf{A}$ \\
\hline $\mathbf{X}$ & $\mathbf{X}$ & & $\mathbf{X}$ & & $\mathbf{X}$ & & $\mathbf{X}$ & & $\mathbf{X}$ & & $\mathbf{X}$ & & $\mathbf{X}$ & & $\mathbf{X}$ & $\mathbf{X}$ & $\mathbf{X}$ & $\mathbf{X}$ \\
\hline O & $\mathbf{O}$ & & O & & $\mathbf{O}$ & & O & & O & & $\mathbf{O}$ & & O & & $\mathbf{O}$ & 0 & O & O \\
\hline O & O & & O & & O & & O & & O & & O & & O & & O & O & O & O \\
\hline O & O & & O & & $\mathbf{O}$ & & O & & O & & O & & O & & 0 & 0 & $\mathbf{O}$ & O \\
\hline O & $\mathbf{O}$ & & O & & O & & 0 & & O & & O & & 0 & & O & O & 0 & O \\
\hline O & O & & O & & O & & O & & 0 & & 0 & & 0 & & O & O & O & O \\
\hline O & O & & O & & O & & O & & O & & O & & O & & O & O & O & O \\
\hline O C-3 & $\mathbf{O}$ & C-1 & o & C-3 & O & C-3 & 0 & C-1 & O & C-2 & o & C-3 & O & C-3 & $\mathbf{N}-1$ & O N-2 & $\mathbf{C}-1$ & OC-1 \\
\hline O $\mathbf{1 6 3}$ & O & 170 & O & $\mathbf{T}$ & 0 & 166 & O & 70 & 01 & 163 & O & 137 & O 1 & 170 & O 135 & O 121 & O 70 & O 166 \\
\hline $\mathbf{X}$ & $\mathbf{X}$ & & $\mathbf{X}$ & & $\mathbf{X}$ & & $\mathbf{X}$ & & $\mathbf{X}$ & & $\mathbf{X}$ & & $\mathbf{X}$ & & $\mathbf{X}$ & $\mathbf{X}$ & $\mathbf{X}$ & $\mathbf{X}$ \\
\hline O & $\mathbf{O}$ & & O & & 0 & & $\mathbf{O}$ & & $\mathbf{O}$ & & O & & O & & 0 & $\mathbf{O}$ & O & O \\
\hline O & O & & O & & O & & O & & O & & O & & O & & O & $\mathbf{O}$ & O & O \\
\hline O & $\mathbf{O}$ & & O & & 0 & & O & & O & & O & & O & & O & O & O & $\mathbf{O}$ \\
\hline O & $\mathbf{O}$ & & $\mathbf{O}$ & & O & & O & & O & & O & & 0 & & 0 & O & O & O \\
\hline O & O & & O & & O & & O & & O & & O & & O & & O & $\mathbf{O}$ & O & O \\
\hline O & $\mathbf{O}$ & & O & & O & & O & & O & & O & & O & & O & O & $\mathbf{O}$ & 0 \\
\hline O C-3 & O & C-3 & o & C-1 & 0 & C-3 & 0 & C-3 & O & C-1 & 0 & C-3 & 0 & C-3 & O N-2 & O C-3 & O C-1 & OC-1 \\
\hline O 70 & O & 132 & 0 & 25 & O & 70 & O & 137 & 0 & 26 & 01 & 166 & 0 & 70 & O 108 & O 166 & O 45 & O 163 \\
\hline $\mathbf{X}$ & $\mathbf{X}$ & & $\mathbf{X}$ & & $\mathbf{X}$ & & $\mathbf{X}$ & & $\mathbf{X}$ & & $\mathbf{X}$ & & $\mathbf{X}$ & & $\mathbf{X}$ & $\mathbf{X}$ & $\mathbf{X}$ & $\mathbf{X}$ \\
\hline O & 0 & & O & & O & & O & & O & & 0 & & O & & O & O & O & O \\
\hline O & $\mathbf{O}$ & & O & & O & & O & & O & & O & & O & & O & O & O & $\mathbf{O}$ \\
\hline O & O & & O & & O & & O & & O & & O & & O & & O & O & $\mathbf{O}$ & $\mathbf{O}$ \\
\hline O & O & & O & & $\mathbf{O}$ & & O & & 0 & & $\mathbf{O}$ & & O & & $\mathbf{O}$ & 0 & $\mathbf{O}$ & O \\
\hline O & $\mathbf{O}$ & & O & & $\mathbf{O}$ & & O & & $\mathbf{O}$ & & O & & O & & O & O & $\mathbf{O}$ & $\mathbf{O}$ \\
\hline $\mathbf{O}$ & O & & O & & O & & O & & 0 & & O & & 0 & & O & $\mathbf{O}$ & O & 0 \\
\hline $\mathbf{C - 3}$ & O & C-2 & O & C-3 & O & C-1 & O & C-3 & $\mathbf{O}$ & C-3 & & C-3 & $\mathrm{O}$ & $\mathrm{C}-3$ & $O_{C-3}$ & $\mathrm{O}_{\mathrm{C}-1}$ & $\mathbf{O}$ & $O_{C-1}$ \\
\hline O 163 & & 45 & $\mathbf{O}$ & 163 & 0 & 170 & O & 25 & 0 & 170 & & 123 & O & 26 & O 70 & $\begin{array}{lll}0 & 170\end{array}$ & O 166 & 0123 \\
\hline
\end{tabular}

Figura 33 - Evolução da sobrevivência das plantas das linhas $V_{5}$ em área de ocorrência da doença no período de 1999 a 2001 (plantio mar/94): O - morte em 1999; O - morte em 2000; O - morte em 2001; O - morte em 2002; O sobreviventes. 
A sobrevivência das plantas das linhagens $V_{5}$ variou após oito anos de cultivo, de 0 a $12,5 \%$, porém em número absoluto uma e no máximo duas plantas sobreviveram à doença (Figura 34). Observa-se, na Tabela 6, que houve uma planta sobrevivente na linhagem testemunha CT. Durante oito anos de cultivo, algumas plantas testemunhas foram substituídas, após sua morte, por outras plantas testemunhas a fim de manter o estande. Por esta razão, acredita-se que esta sobrevivente é uma planta jovem (Figura 37), ainda sem sintoma da doença.

Mortalidade 1994-1999 Q Mortalidade $2000 \square$ Mortalidade 2001 Mortalidade 2002 Q Sobrevivência 1994-2002

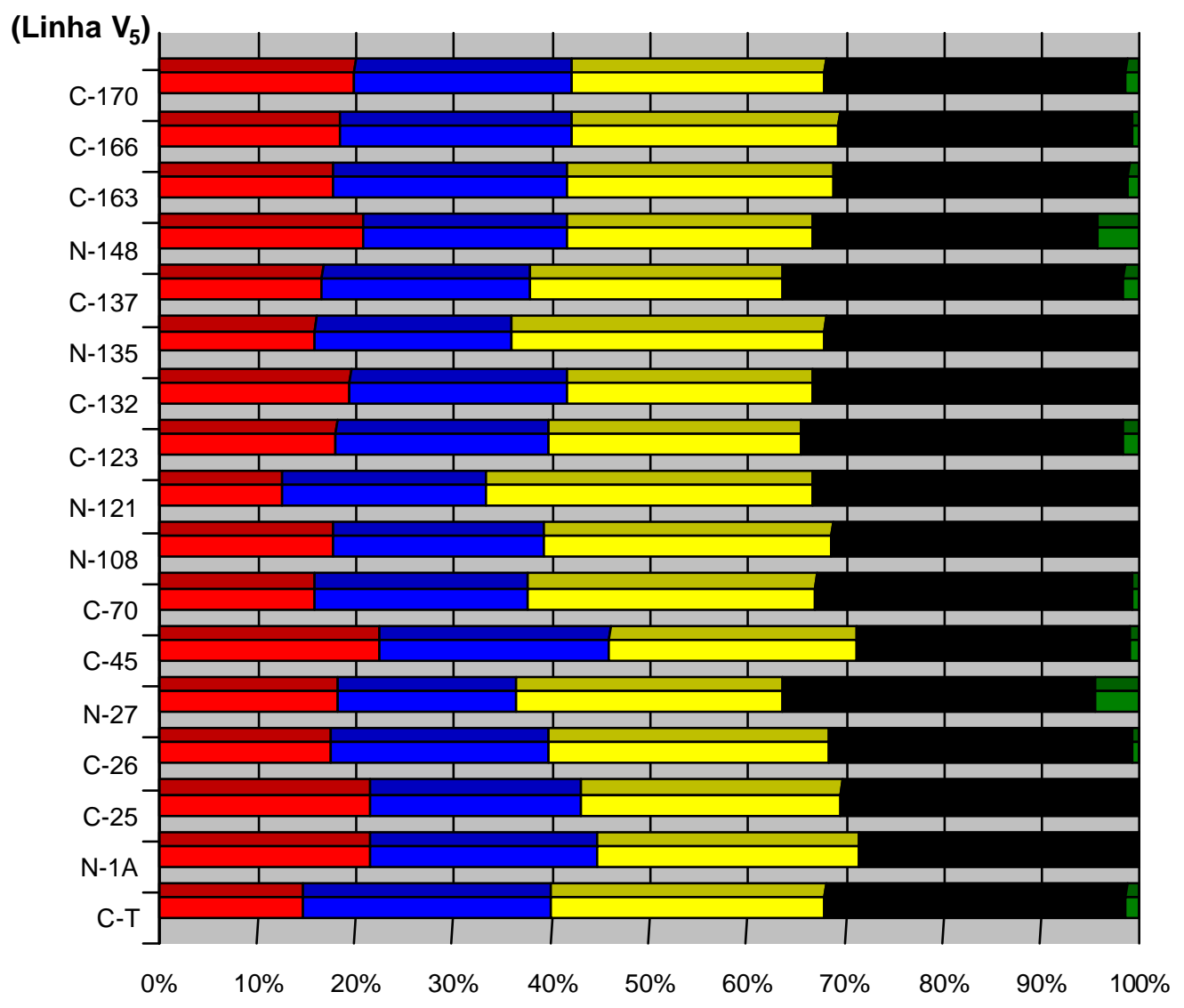

Figura 34 - Mortalidade e sobrevivência de plantas de linhagens $V_{5}$ durante o período de cultivo de 1994 a 2002. 
A avaliação individual das plantas sobreviventes das linhagens $V_{5}$ revelou variação muito pequena para os caracteres de peso de 100 frutos, comprimento de espiga, peso e número de frutos por espiga, porém quanto a produção houve uma grande diferença. Nas plantas originadas de estacas irradiadas variou de 400 a $2.700 \mathrm{~g}$ e na planta de estaca não irradiada, a produção foi ínfima, não ultrapassando $10 \mathrm{~g}$ (Tabela 76). A baixa produção deveu-se a grande falha na formação dos frutos, cuja média de 32,6 frutos por espiga foi inferior às médias dos anos $2000(38,09)$ e 2001 $(47,54)$, que apresentaram média de produção superior a $4.000 \mathrm{~g}$. Este aspecto está ligado àbaixa umidade relativa do ar durante o período de polinização natural, ou seja, chuvas menos abundantes, que têm um papel importante na germinação do pólen, fecundação e desenvolvimento do ovário (Albuquerque \& Condurú, 1971). Destacaram-se as plantas C3-70P2 e C3-163P4, com produção superior a $2.000 \mathrm{~g}$. Por outro lado, o rendimento de pimenta preta, secagem de 100 frutos, variou de 31,27 a $42,85 \%$.

As plantas originadas de estacas irradiadas cultivadas em área de ocorrência da doença, apresentaram uma grande tendência àadaptação a essa adversidade, pois as plantas $V_{5}$ apresentaram uma maior estabilidade quanto aos caracteres de produção. Observou-se também, que ramos ortotrópicos e plagiotrópicos foram muito variáveis quanto ao número, variação de 3 a 7 e 30 a 258, respectivamente. Variáveis não diretamente proporcionais àprodução, e que indicou que 3 ramos ortotrópicos com ramos plagiotrópicos bem distribuídos podem ser suficientes para uma boa produção.

Plantas individuais da cultivar Guajarina foram avaliadas para servirem de comparação com as plantas em estudos de diversidade genética. É uma cultivar que apresenta características muito favoráveis de produção, tanto que foi observado comprimento longo da espiga $(>11,0 \mathrm{~cm}$ ), número elevado de frutos por espiga (média $>58$ frutos), peso úmido quanto seco de 100 frutos elevados e rendimento de pimenta preta de cerca de 44,0\%, cuja produção de pimenta preta em condições adequadas de cultivo alcança 3,0kg/planta. Devido a grande susceptibilidade à doença fusariose e outras enfermidades, e por serem mais exigentes æ̀s condições nutricionais, a utilização pelos produtores é de cerca de $29 \%$, enquanto a área utilizada com a cultivar Cingapura é de cerca de 70\% (Duarte \& Albuquerque, 1999). 
Tabela 76. Avaliação individual das plantas $V_{5}$ sobreviventes quanto aos caracteres de produção e rendimento de pimenta preta no ano de 2002.

\begin{tabular}{|c|c|c|c|c|c|c|c|c|c|}
\hline \multirow[t]{2}{*}{ Planta. Linha } & \multicolumn{2}{|c|}{100 frutos $(\mathrm{g})$} & \multirow{2}{*}{$\begin{array}{c}\text { Rend. } \\
(\%)\end{array}$} & \multicolumn{2}{|c|}{ Ramos } & \multicolumn{3}{|c|}{ Espiga } & \multirow{2}{*}{$\begin{array}{c}\text { Produção } \\
\text { (g) }\end{array}$} \\
\hline & ùmido & Seco & & Ort. & Plag. & frutos & $\begin{array}{l}\text { Peso } \\
\text { (g) }\end{array}$ & Comp.(cm) & \\
\hline 1. C1-123P4 & 9,05 & 2,83 & 31,27 & 6 & 163 & 46,2 & 4,55 & 7,8 & 400 \\
\hline 2. C3-123P7 & 11,21 & 4,22 & 37,64 & 3 & 117 & 43,5 & 5,12 & 8,7 & 1.400 \\
\hline 3. $\mathrm{C} 1-163 \mathrm{P} 8$ & 11,22 & 4,00 & 35,65 & 7 & 60 & 18,3 & 2,35 & 7,9 & 800 \\
\hline 4. C3-163P4 & 12,2 & 4,99 & 40,9 & 6 & 258 & 27,8 & 3,54 & 8,3 & 2.350 \\
\hline 5. $\mathrm{C} 1-166 \mathrm{P} 4$ & 12,58 & 5,39 & 42,85 & 6 & 30 & 36,3 & 4,73 & 8,5 & 2.700 \\
\hline 6. C2-45P6 & 10,81 & 3,62 & 33,49 & 4 & 117 & 45,3 & 4,51 & 8,2 & 800 \\
\hline 7. C3-70P2 & 11,48 & 3,88 & 33,8 & 6 & 158 & 35,7 & 4,14 & 7,4 & 2.000 \\
\hline 8. $\mathrm{C} 1-137 \mathrm{P} 2$ & 11,85 & 4,94 & 41,69 & 3 & 44 & 32,7 & 3,72 & 7,1 & 1.800 \\
\hline 9. $\mathrm{C} 1-170 \mathrm{P} 1$ & 12,92 & 4,95 & 38,31 & 4 & 80 & 16 & 2,42 & 7,3 & 1.000 \\
\hline 10. C3-170P1 & 11,06 & 4,29 & 38,79 & 6 & 158 & 35,7 & 4,08 & 8,8 & 1.200 \\
\hline 11. N3-148P2 & 10,87 & 4,53 & 41,67 & 6 & 80 & 31,9 & 3,56 & 7,6 & 750 \\
\hline 12. N2-27P3 & 10,79 & 3,73 & 34,57 & 4 & 105 & 41,8 & 4,40 & 8,1 & 1.400 \\
\hline 13. C3-26P1 & 10,13 & 3,43 & 33,86 & 6 & 112 & 41,7 & 4,24 & 7,4 & 1.800 \\
\hline 14. C3-T & & & & 7 & 90 & 4,2 & 0,87 & 6,3 & 9 \\
\hline Média & 11,24 & 4,21 & 37,26 & 5,3 & 112,3 & 32,6 & 3,73 & 7,81 & 1.315 \\
\hline Guaj-P1 & - & - & - & & & 78,8 & 10,11 & 15,5 & - \\
\hline Guaj-P2 & 19,55 & 8,60 & 43,99 & & & 58,5 & 11,97 & 11,2 & \\
\hline
\end{tabular}

A análise de divergência genética através de componentes principais e variáveis canônicas permitiu agrupar os materiais, pois através de ambas, quer pelos dois componentes principais quer pelas duas variáveis canônicas, foi possível explicar mais de $70,0 \%$ da variabilidade genética existente.

No primeiro caso, análise da divergência genética por componentes principais, considerando as 14 plantas sobreviventes após oito anos de cultivo, foi possível identificar cinco grupos de plantas, sendo que a planta 14 (linhagem $\mathrm{CT}$, cultivar original) foi mais divergente das demais, principalmente da planta 4 (C3-163P4) em relação ao componente principal 1 (IPCA 1), o qual apresentou uma proporção de mais de $50 \%$ da explicação da variabilidade genética existente (Figura 35). 


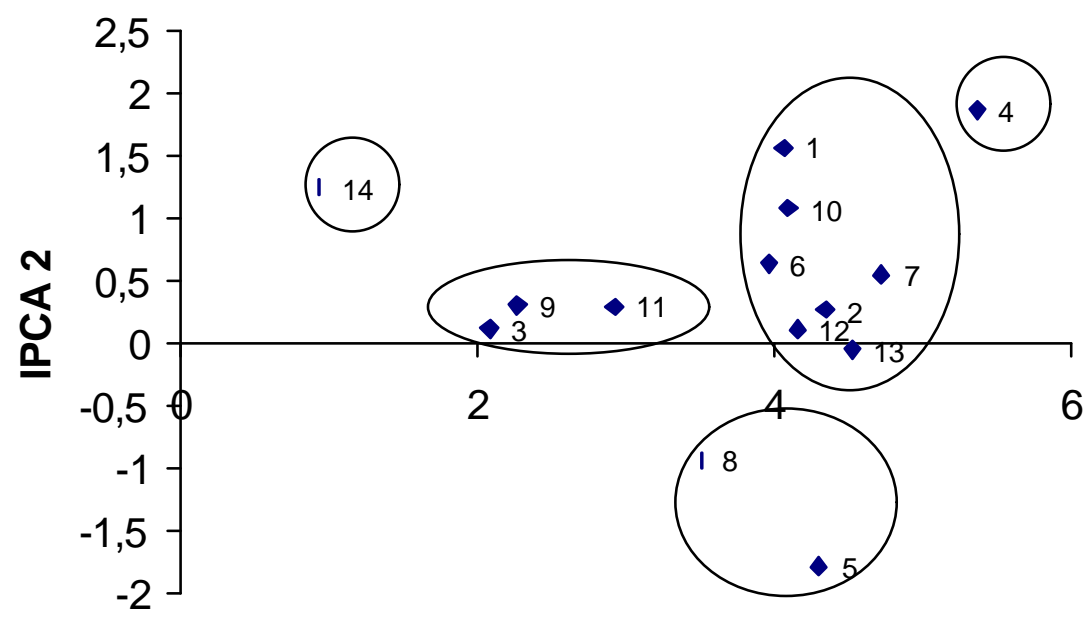

IPCA 1

Figura 35 - Gráfico de dispersão de 14 plantas $v_{5}$ quanto a diversidade genética obtida através de análise por componentes principais.

Em relação à divergência genética por variáveis canônicas, a qual incluiu plantas da cultivar guajarina, foi possível identificar dois grupos, um formado pelas plantas da cultivar guajarina (Guaj-P1 e Guaj-P2) e outro pelas demais plantas, sendo fundamentais para a separação da planta Guaj-P1, as variáveis, como comprimento e peso da espiga. Ademais, o número de frutos por espiga (NS) apresentou maior variância, sendo a planta C3-T relativamente mais distante das demais plantas $V_{5}$. A variável canônica 1 explicou cerca de $74,33 \%$ da variabilidade genética existente enquanto a variável canônica 2, 16,30\% (Figura 36). 


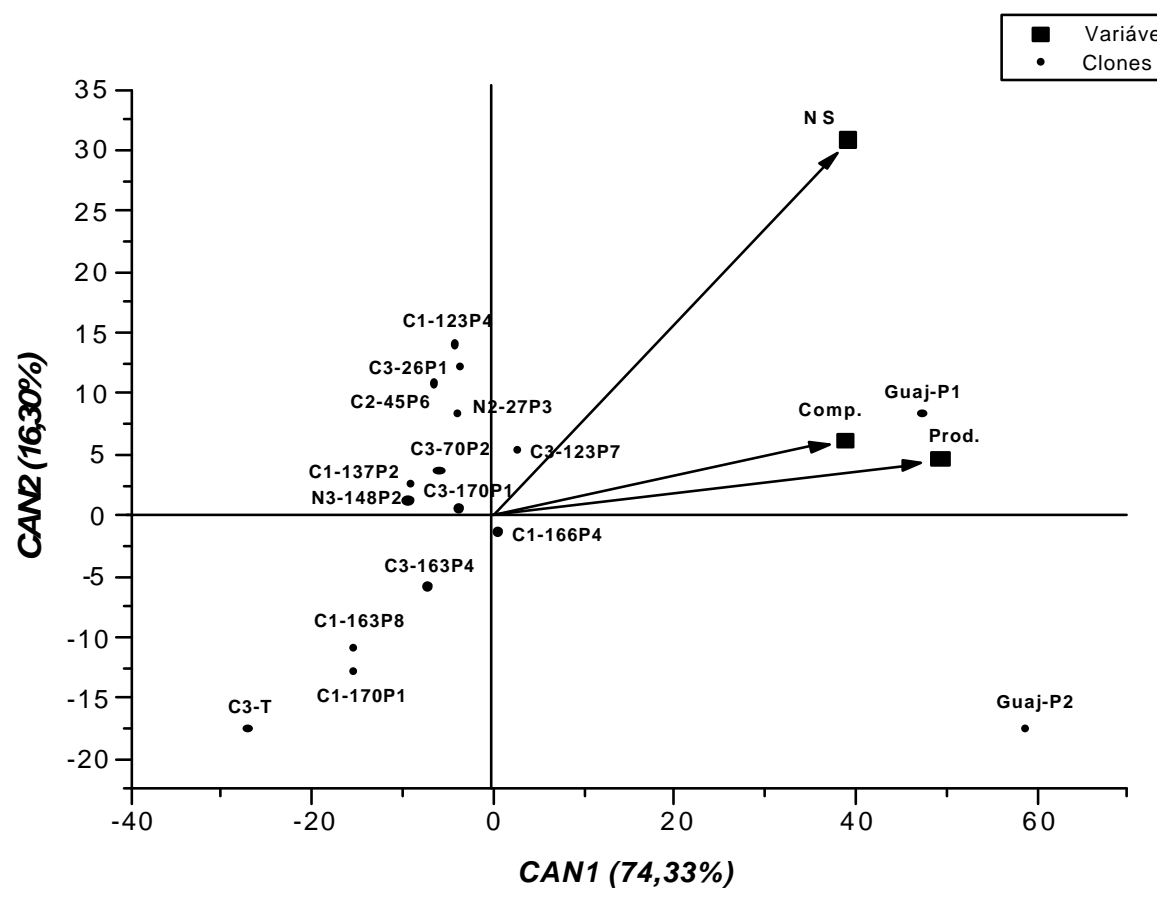

Figura 36 - Análise da divergência genética por variáveis canônicas entre plantas ${ }^{\mathrm{NS}}$ Número de frutos por espiga Comp. Comprimento da espiga Prod. Produção de pimenta verde

Pelo exposto, o uso da radiação gama na ampliação da variabilidade genética em pimenta-do-reino, visando a seleção de plantas resistentes e/ou tolerantes à doença fusariose, pode ser uma alternativa viável, desde que métodos mais apropriados de seleção e análises genéticas sejam desenvolvidos para auxiliar o processo. O desenvolvimento de tecnologias in vitro permitirá, principalmente a redução do tempo para a obtenção de novas formas alélicas, tanto para adaptação às condições de ocorrência da doença como para produção de frutos. As plantas $V_{5}$ sobreviventes apresentaram capacidade adaptativa à condições de cultivo em área de ocorrência da doença e uma boa performance quanto a produção, sendo o comportamento muito semelhante a cultivar original quanto aos outros parâmetros (Figura 37). 


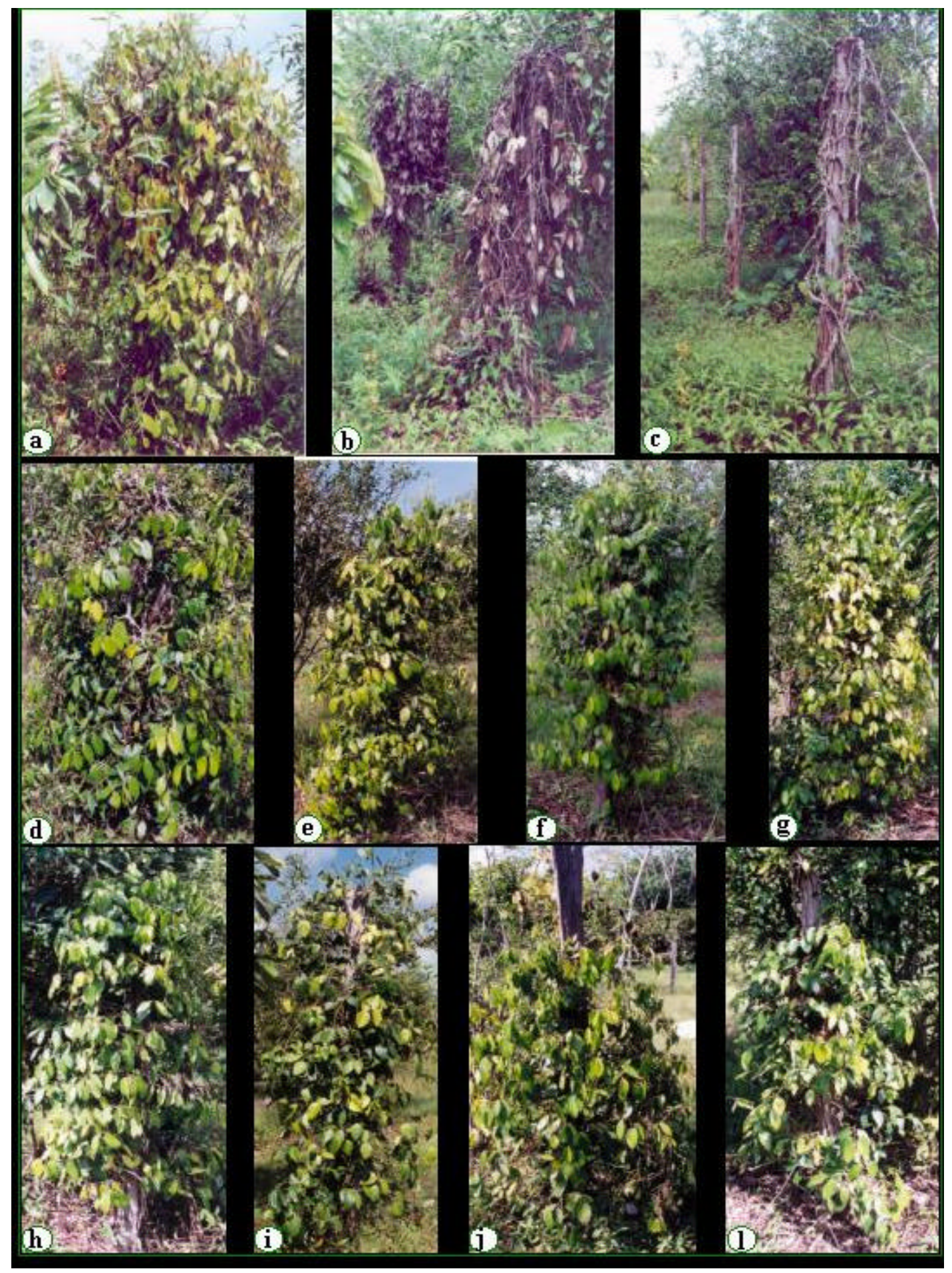

Figura 37 - Mortalidade e sobrevivência de plantas $V_{5}$ em área de ocorrência da doença fusariose.

a-c) Morte pelo ataque do fungo Fusarium solani f. sp. piperis

d-j) Plantas $V_{5}$ sobreviventes

I) Planta originada de estaca não irradiada (CT) 


\subsubsection{Avaliação Agronômica em plantas $V_{6}$}

A performance das plantas $V_{6}$ quanto aos caracteres avaliados para as plantas $V_{5}$ foram muito semelhantes, nos dois anos avaliados (2001 e 2002), Tabela 77 , mas devido a grande heterogeneidade do solo em cultivo, houve grande variação quanto a produção das plantas, desde 33 a $6.000 \mathrm{~g}$ por planta, principalmente pelas plantas crescidas em solos muito argilosos e compactos, enquanto em solos menos argilosos com textura mais friável, as plantas produziram muito bem. A média de rendimento de pimenta preta por planta foi de 30 a 36\%, sendo que a maior produção alcançou $2.058 \mathrm{~g} /$ planta, superior a média da região com a cultivar Cingapura de 1,5 $\mathrm{kg} /$ planta (Duarte \& Albuquerque, 1999).

Tabela 77. Performance de plantas $V_{6}$ quanto aos caracteres de produção e rendimento de pimenta preta avaliadas em dois anos consecutivos, plantio em março de 1998.

\begin{tabular}{|c|c|c|c|c|}
\hline \multirow[t]{2}{*}{ Caractere } & \multicolumn{2}{|c|}{2001} & \multicolumn{2}{|c|}{2002} \\
\hline & Variação & Média $\pm s$ & variação & Média $\pm s$ \\
\hline \multicolumn{5}{|l|}{ Espiga: } \\
\hline $\begin{array}{l}\text { Comprimento } \\
(\mathrm{cm})\end{array}$ & $4,0-15,5$ & $8,41 \pm 1,06$ & $4,2-12,2$ & $7,54 \pm 0,69$ \\
\hline Peso (g) & $1,20-8,96$ & $5,09 \pm 1,10$ & $0,88-8,92$ & $3,94 \pm 0,78$ \\
\hline Frutos & $7-74$ & $38,42 \pm 9,02$ & $4-79$ & $30,73 \pm 6,58$ \\
\hline \multicolumn{5}{|l|}{ Peso de 100 frutos: } \\
\hline Úmido & $6,64-14,28$ & $11,16 \pm 1,47$ & $7,70-15,31$ & $11,25 \pm 2,22$ \\
\hline Seco & - & - & $2,01-6,69$ & $4,21 \pm 1,54$ \\
\hline Rendimento $(\%)^{2}$ & - & - & $22,54-42,14$ & $36,25 \pm 7,67$ \\
\hline \multicolumn{5}{|l|}{ Produção $(\mathrm{g})$ : } \\
\hline Pimenta verde & $59-6.000$ & $1.014 \pm 908$ & $33-5.690$ & $1.625 \pm 1.358$ \\
\hline Pimenta preta & $20-2.058$ & $362,2+316,4$ & & \\
\hline Rendimento $(\%)^{2}$ & $25,73-60,50$ & $36,57 \pm 6,02$ & $18.000 / 59.869$ & 30,06 \\
\hline \multicolumn{5}{|l|}{ Ramos: } \\
\hline Ortotrópicos & - & - & $2-13$ & $4,78 \pm 2,18$ \\
\hline Plagiotrópicos & - & - & $12-366$ & $206,14 \pm 99,41$ \\
\hline
\end{tabular}

Menor e maior valor registrado em cada ano para o parâmetro avaliado

${ }^{2}$ Após a secagem ao sol (pimenta preta) ou estufa (100 sementes) em relação ao peso úmido

A floração das plantas $V_{6}$ deu-se também logo após o início das chuvas que ocorreram em meados de dezembro. Observou-se que $89,90 \%$ das plantas apresentavam florescimento um mês após o início do período chuvoso e, depois de quatro meses, todas as plantas estavam com flores e iniciando o desenvolvimento de 
frutos. Os frutos ficaram aptos a serem colhidos a partir de seis meses do início do florescimento, sendo que em agosto a colheita foi realizada totalmente. Este comportamento foi semelhante ao observado com as plantas da cultivar Cingapura utilizada pelos produtores rurais. Portanto, quanto aos aspectos fisiológicos e morfológicos, as plantas $V_{6}$ se apresentaram idênticas æ̀ plantas da cultivar original (Cingapura).

A mutagênese através da radiação gama visando o melhoramento genético da pimenta-do-reino contra a doença fusariose parece ser uma alternativa mais viável, quando associada àtecnologia in vitro, tais como seleção in vitro, avanço de geração através do processo de micropropagação, avaliação genético-molecular para detecção das novas formas alélicas e aos métodos adequados de seleção artificial e natural contra o fungo. Todos esses fatores integrados suportarão a manipulação de grandes populações a tratamento mutagênico, reduzirão o tempo de estabilização das quimeras, e permitirão um "screening" in vitro de materiais com potencial para resistência à doença, cuja variação genética poderá ser detectada através de análise genético-molecular e confirmada a expressão do caráter por métodos apropriados de seleção tanto em casa-de-vegetação quanto em campo. Por conseguinte, uma vez obtido um mutante com resistência e potencial produtivo, este poderá ser clonado in vitro em menor tempo e maior quantidade, e lançado como uma nova cultivar e/ou incorporado aos programas de melhoramento genético da cultura. Portanto, essas tecnologias geradas e integradas serão instrumentos poderosos, principalmente para redução de tempo e custos na obtenção de uma nova cultivar. 


\section{CONCLUSÕES}

O uso da indução de mutação através da radiação gama associada à tecnologia in vitro é a alternativa mais viável para o melhoramento genético da pimenta-do-reino, visando a obtenção de genótipos resistentes e/ou tolerantes à doença fusariose, uma vez que não se encontra, dentro da espécie, fonte de resistência genética. A tecnologia in vitro é suportada pelo processo de micropropagação, mutagênese e seleção in vitro de variantes tolerantes aos metabólitos do fungo, que deve estar associada ⿱亠̀ estratégias adequadas de seleção artificial com suspensão de esporos do fungo e seleção natural em área de ocorrência da doença, e avaliação dos materiais selecionados quanto aos caracteres de produção.

Este trabalho permite as seguintes conclusões:

- O processo de micropropagação é viável através da obtenção de plantas fornecedoras de explantes, obtidas a partir de estacas em casa-de-vegetação, de sementes em meio básico de cultura MS com 0,17g.L ${ }^{-1}$ de $\mathrm{NaH}_{2} \mathrm{PO}_{4}$ e de embriões zigóticos em meio básico MS com $0,17 \mathrm{~g} \cdot \mathrm{L}^{-1}$ de $\mathrm{NaH}_{2} \mathrm{PO}_{4}$ e carvão ativado a $0,2 \%$, crescidas em sala de luz; proliferação de gemas em meio básico MS com BAP 0,5 e IAA 0,2 mg. $\mathrm{L}^{-1}$; enraizamento de brotos acima de 2,0 cm em meio de cultura com NAA $0,1 \mathrm{mg} \cdot \mathrm{L}^{-1}$ ou produção de "plantlets" a partir de gemas em meio com 1/2MS e IBA a 0,2 mg. $\mathrm{L}^{-1}$ ou mesmo em meio de multiplicação de gemas com carvão ativado a $0,2 \%$; aclimatação em condições de umidade saturada por uma semana em substrato do tipo vermiculita e formação de mudas em sacos plásticos pretos com solo e substrato comercial "Plantmax";

- A indução de calos é satisfatória em meio básico de cultura SH suplementado com 2,0 mg. $\mathrm{L}^{-1}$ de dicamba e $0,2 \mathrm{mg} \cdot \mathrm{L}^{-1}$ de BAP, tanto para segmentos de entrenós e folhas quanto para embriões zigóticos; 
- A dose de 20 Gy da radiação gama é mais apropriada para mutagênese em gemas cultivadas in vitro;

- A seleção in vitro de variantes contra a doença fusariose é possível através da concentração de $55 \%$ do filtrado da cultura do fungo Fusarium solani f. sp. piperis, cultivado durante 28 dias em meio Czapek-Dox;

- É adequada a concentração de $2 \times 10^{6}$ esporos do fungo por ml em suspensão para seleção artificial contra a doença fusariose em casa-de-vegetação; e

- As plantas $V_{5}$ e $V_{6}$ selecionadas a partir das estacas irradiadas com raios-gama apresentam maior longevidade em área de ocorrência da fusariose, maior produção e pouco são afetadas quanto a comprimento, peso e número de frutos por espiga, e peso de 100 sementes, mas são divergentes geneticamente da cultivar original.

Além disso, o desenvolvimento de técnicas de marcadores moleculares é fundamental para avaliar e selecionar os mutantes desejáveis, pois toda essa tecnologia gerada reduzirá, ainda mais, o tempo de melhoramento genético e lançamento de novas cultivares de pimenta-do-reino. 
ANEXOS 
ANEXO A - Situação da cultura da pimenta-do-reino no Brasil no período de 1991-2000 quanto àprodução, área, rendimento, principais Estados produtores brasileiros e principais países importadores.

\begin{tabular}{|c|c|c|c|c|c|c|c|c|c|c|}
\hline Característica & 1991 & 1992 & 1993 & 1994 & 1995 & 1996 & 1997 & 1998 & 1999 & 2000 \\
\hline Produção (1.000 t) & 83,7 & 32,9 & 41,4 & 34,7 & 33,7 & 34,5 & 21,9 & 23,1 & 27,8 & 45,5 \\
\hline Área colhida (1.000 ha) & 36,8 & 29,0 & 23,3 & 20,8 & 18,6 & 18,2 & 11,8 & 11,2 & 13,2 & 15,9 \\
\hline Rendimento (kg/ha) & $2.277,0$ & $1.132,0$ & $1.776,0$ & 1.668 & $1.815,0$ & 1.890, & $1.853,0$ & $2.071,0$ & $2.099,0$ & $2.868,0$ \\
\hline Exportações (1.000 t) & 48,2 & 26,4 & 26,9 & 22,3 & 22,2 & 24,2 & 14,0 & 17,2 & 19,6 & 20,449 \\
\hline
\end{tabular}

\section{Principais Produtores (1.000 t)}

$\begin{array}{lcccccccccc}\text { Pará } & 75,3 & 25,3 & 33,8 & 27,8 & 27,8 & 28,6 & 16,6 & 17,96 & 29,4 & 40,4 \\ \text { Espírito Santo } & 5,5 & 4,7 & 4,5 & 3,6 & 2,8 & 2,9 & 2,6 & 2,5 & 2,6 & 3,2 \\ \text { Bahia } & 1,7 & 2,0 & 2,1 & 2,3 & 2,3 & 2,4 & 1,9 & 2,3 & 1,4 & 1,5 \\ & & & & & & & & & & \\ \text { Principais Importadores (1.000 t) } & & & & & & & & & & \\ \text { Estados Unidos } & 15,3 & 6,1 & 4,6 & 8,1 & 3,0 & 4,8 & 4,6 & 5,7 & 8,1 & 7,999 \\ \text { Alemanha } & 5,7 & 4,0 & 7,3 & 4,0 & 4,3 & 4,7 & 2,4 & 2,4 & 4,0 & 2,532 \\ \text { Países Baixos } & 4,8 & 1,1 & 2,0 & 1,8 & 2,1 & 4,0 & 2,1 & 3,1 & 3,4 & 2,231 \\ \text { Argentina } & 1,8 & 0,8 & 1,0 & 1,3 & 1,1 & 1,3 & 1,1 & 1,4 & 0,8 & 0,925\end{array}$

Fonte: Fundação Instituto Brasileiro de Geografia e Estatística - IBGE (2001) 
ANEXO B - Principais países produtores e exportadores mundiais de pimenta-do-reino no período de 1992 - 1996.

\begin{tabular}{|c|c|c|c|c|c|c|c|}
\hline Países & Fator & 1992 & 1993 & 1994 & 1995 & 1996 & Média \\
\hline \multirow[t]{3}{*}{ Brasil } & Prod.(t) & 27.500 & 25.000 & 23.000 & 20.000 & 19.500 & $23.000,0$ \\
\hline & Exp. (t) & 25.702 & 24.119 & 21.103 & 21.250 & 15.300 & $21.494,8$ \\
\hline & US\$1.000 & 22.349 & 28.242 & 40.852 & 50.297 & 36.564 & $35.660,8$ \\
\hline \multirow[t]{3}{*}{ Índia } & Prod.(t) & 60.000 & 55.000 & 50.000 & 55.000 & 60.000 & $56.000,0$ \\
\hline & Exp. (t) & 19.399 & 47.228 & 34.111 & 24.541 & 35.075 & $32.070,8$ \\
\hline & US\$1.000 & 22.405 & 54.801 & 60.644 & 53.636 & 77.420 & $53.781,2$ \\
\hline \multirow[t]{3}{*}{ Indonésia } & Prod.(t) & 62.000 & 23.500 & 42.500 & 59.000 & 39.200 & $45.240,0$ \\
\hline & Exp. (t) & 61.438 & 25.801 & 35.134 & 56.129 & 34.000 & $42.500,4$ \\
\hline & US\$1.000 & 61.385 & 43.634 & 76.470 & 150.561 & 98.988 & $86.207,6$ \\
\hline \multirow[t]{3}{*}{ malásia } & Prod.(t) & 26.000 & 17.600 & 16.000 & 13.000 & 12.000 & $16.920,0$ \\
\hline & Exp. (t) & 21.932 & 15.727 & 22.269 & 13.975 & 14.800 & $17.740,6$ \\
\hline & US\$1.000 & 19.359 & 21.777 & 46.516 & 42.432 & 39.271 & $33.871,0$ \\
\hline \multirow[t]{3}{*}{ Sri Lanka } & Prod.(t) & 3.255 & 5.000 & 5.000 & 3.725 & 4.312 & $4.258,4$ \\
\hline & Exp. (t) & 2.127 & 7.779 & 3.411 & 2.396 & 2.100 & $3.562,6$ \\
\hline & US\$1.000 & 2.477 & 7.812 & 6.170 & 5.344 & 5.032 & $5.367,0$ \\
\hline \multirow[t]{3}{*}{ Vietnam } & Prod.(t) & 7.830 & 18.500 & 20.000 & 20.000 & 20.000 & 17266,0 \\
\hline & Exp. (t) & 22.358 & 14.801 & 15.000 & 15.000 & 15.000 & $82.159,0$ \\
\hline & US\$1.000 & 15.290 & 17.169 & 27.600 & 37.020 & 33.180 & $26.051,8$ \\
\hline \multirow[t]{3}{*}{ China } & Prod.(t) & 12.321 & 10.461 & 12.409 & 8.279 & 11.754 & $11.044,8$ \\
\hline & Exp. (t) & 181 & 2.441 & 7.761 & 5.000 & 5.000 & $4.076,6$ \\
\hline & US $\$ 1.000$ & 241 & 4.345 & 19.405 & 3.184 & 1.561 & $5.747,2$ \\
\hline
\end{tabular}

Fonte: International Pepper Community - IPC (1997) 
ANEXO C - Consumo de pimenta-do-reino nos principais países produtores no período de 1993 a 1997.

Consumo

$\square$ Brasil $\square$ Índia $\square$ Indonésia \malásia $\square$ Sri Lanka $\square$ Vietnam $\square$ China

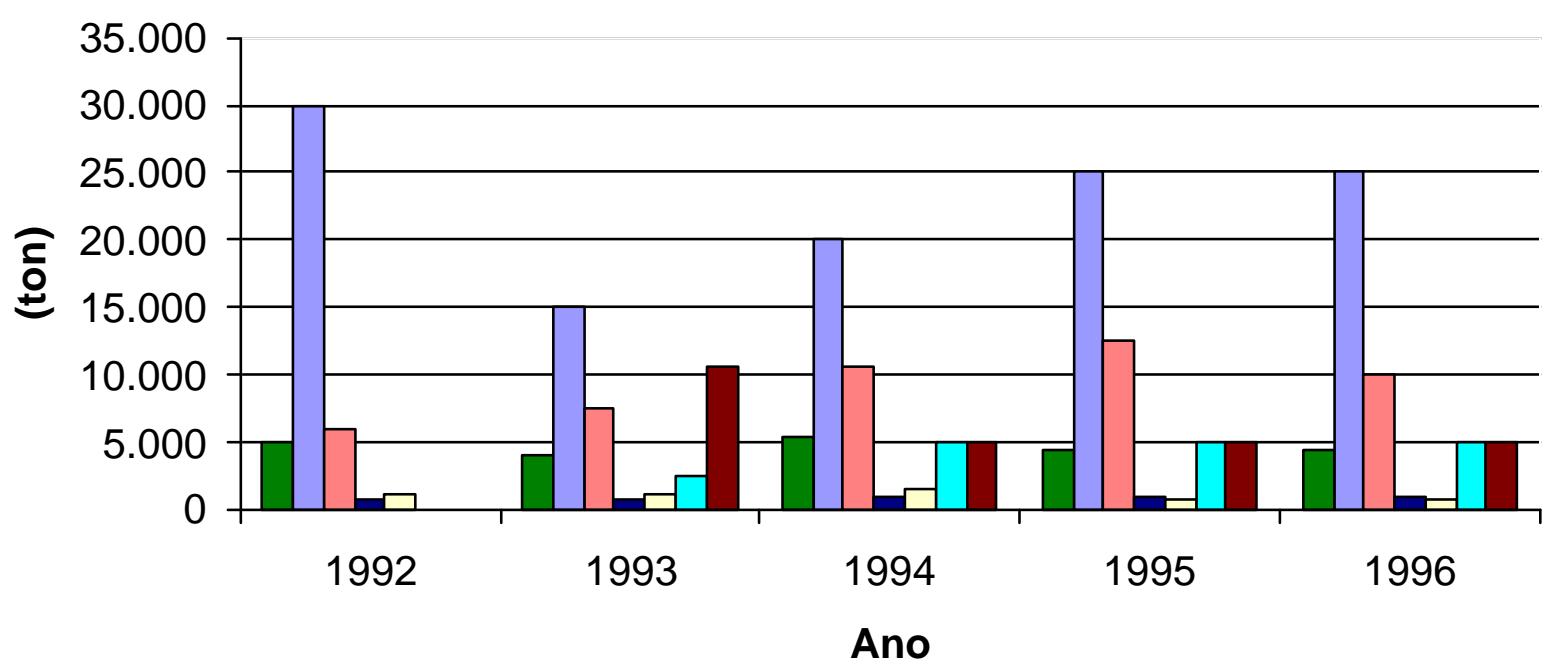

Fonte: IPC (1997)

ANEXO D - Preço da pimenta-do-reino no período de 1993 a 1997

Preço da pimenta brasileira

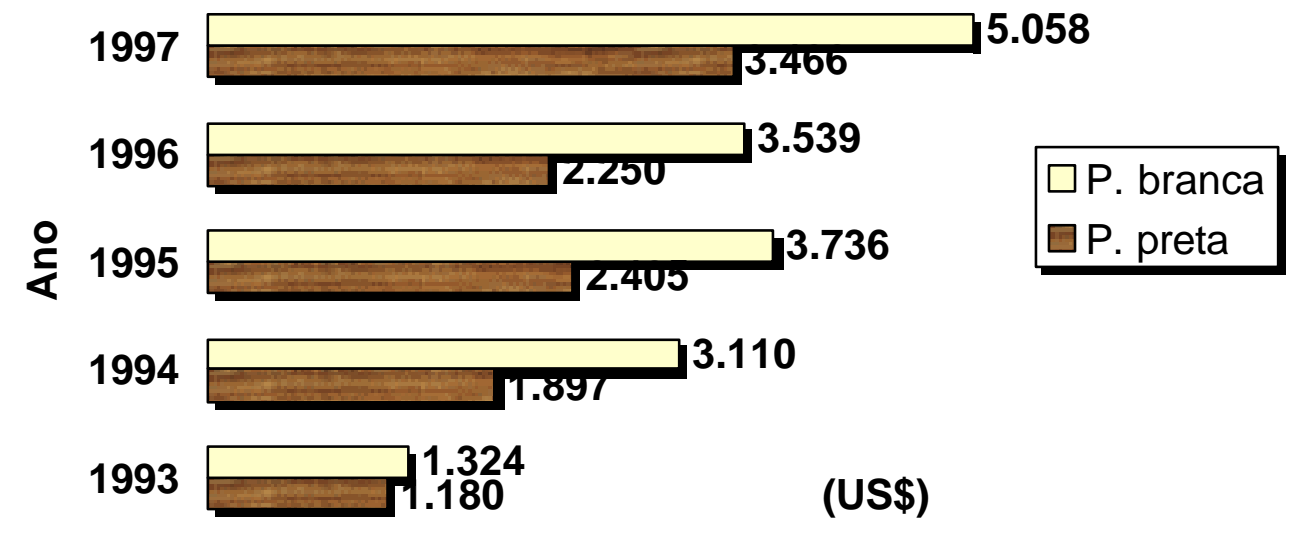

Fonte: IPC (1997) 
ANEXO E - Composição de meios básicos de cultura de Schenk \& Hildebrandt (1972) e de Murashige \& Skoog (1962).

\begin{tabular}{|c|c|c|}
\hline Composto & $\mathrm{SH}\left(\mathrm{mg} \cdot \mathrm{L}^{-1}\right)$ & $M S\left(m g \cdot L^{-1}\right)$ \\
\hline \multicolumn{3}{|l|}{ Macronutrientes } \\
\hline$-\mathrm{KNO}_{3}$ & 2.500 & 1.900 \\
\hline$-\mathrm{NH}_{4} \mathrm{NO}_{3}$ & - & 1.650 \\
\hline$-\mathrm{NH}_{4} \mathrm{H}_{2} \mathrm{PO}_{4}$ & 300 & - \\
\hline - $\mathrm{MgSO}_{4} .7 \mathrm{H}_{2} \mathrm{O}$ & 400 & 370 \\
\hline$-\mathrm{CaCl}_{2} \cdot 2 \mathrm{H}_{2} \mathrm{O}$ & 200 & 440 \\
\hline$--\mathrm{KH}_{2} \mathrm{PO}_{4}$ & - & 170 \\
\hline \multicolumn{3}{|l|}{ Micronutrientes } \\
\hline$-\mathrm{MnSO}_{4} \cdot \mathrm{H}_{2} \mathrm{O}$ & 10,0 & \\
\hline$-\mathrm{MnSO}_{4} \cdot 4 \mathrm{H}_{2} \mathrm{O}$ & - & 22,3 \\
\hline$-\mathrm{KI}$ & 1,0 & 0,83 \\
\hline$-\mathrm{H}_{3} \mathrm{BO}_{3}$ & 5,0 & 6,2 \\
\hline$-\mathrm{ZnSO}_{4} \cdot 7 \mathrm{H}_{2} \mathrm{O}$ & 1,0 & 8,6 \\
\hline - $\mathrm{CuSO}_{4}$ & 0,2 & - \\
\hline - $\mathrm{CuSO}_{4} \cdot 5 \mathrm{H}_{2} \mathrm{O}$ & - & 0,025 \\
\hline - $\mathrm{Na}_{2} \mathrm{MoO}_{4} \cdot 2 \mathrm{H}_{2} \mathrm{O}$ & 0,1 & 0,25 \\
\hline$-\mathrm{CoCl}_{2} \cdot 6 \mathrm{H}_{2} \mathrm{O}$ & 0,1 & 0,025 \\
\hline \multicolumn{3}{|l|}{ Fe-EDTA } \\
\hline - $\mathrm{FeSO}_{4} .7 \mathrm{H}_{2} \mathrm{O}$ & 15,0 & 27,8 \\
\hline - NaEDTA & 20,0 & 37,3 \\
\hline \multicolumn{3}{|l|}{ Outros } \\
\hline Cisteína - HCl & 40,0 & - \\
\hline Sacarose & $40.000,0$ & $30.000,0$ \\
\hline $\mathrm{pH}$ & 5,8 & 5,8 \\
\hline
\end{tabular}

ANEXO F - Composição de vitaminas de Staba e de Murashige \& Skoog (1962).

\begin{tabular}{l|c|c}
\hline Composto & $\mathrm{SH}\left(\mathrm{mg} \cdot \mathrm{L}^{-1}\right)$ & $\mathrm{MS}\left(\mathrm{mg} \cdot \mathrm{L}^{-1}\right)$ \\
\hline & 2 & 0,1 \\
- Tiamina - HCl & 2 & 0,5 \\
- Ácido nicotínico & 2 & 0,5 \\
- Piridoxina - HCl & 1 & - \\
- Pantotenato de cálcio & 0,5 & \\
- Ácido Para-aminobenzóico & 1,5 & \\
- Cianocobalamina & 0,5 & \\
- Riboflavina & 1,0 & \\
- Colina Cloride & 0,5 & \\
- Ácido fólico & 1,0 & 2,0 \\
- Biotina & - & 100,0 \\
- Glicina & - & \\
- Mio-inositol & &
\end{tabular}


ANEXO G - Meios de Czapek Dox e batata-sacarose-agar para cultivo de fungo.

\begin{tabular}{lc|c}
\hline Composto & Czapek Dox $\left(\mathrm{g} \cdot \mathrm{L}^{-1}\right)$ & $\mathrm{BSA}\left(\mathrm{g} \cdot \mathrm{L}^{-1}\right)$ \\
\hline & & \\
$-\mathrm{NaNO}_{3}$ & 3,0 & \\
$-\mathrm{MgSO}_{4} \cdot 7 \mathrm{H}_{2} \mathrm{O}$ & 0,5 & \\
$-\mathrm{KH}_{2} \mathrm{PO}_{4}$ & 1,0 & \\
$-\mathrm{KCl}_{2} \mathrm{H}_{2} \mathrm{O}$ & 0,5 & \\
- FeSO & & \\
- Sacarose & 0,01 & 10,0 \\
- Fe-EDTA & 30,0 & \\
- Disco de batata sem pele & $2,5 \mathrm{ml}$ & \\
- Agar & (Fe-EDTA 20x MS) & 200,0 \\
& & 20,0 \\
\hline
\end{tabular}

ANEXO H - Peso molecular (P. M.) e quantidade do produto em mg. $\mathrm{L}^{-1}$ para obtenção de uma solução a $1 \mu \mathrm{M}$.

\begin{tabular}{l|l|l}
\hline Composto & P. M. & $1 \mu \mathrm{M}=\mathrm{mg} \cdot \mathrm{L}^{-1}$ \\
\hline 2,4-D & 221,0 & \\
$\mathrm{AgNO}_{3}$ & 169,87 & 0,221 \\
$\mathrm{BAP}(\mathrm{BA})$ & 225,3 & 0,16987 \\
Dicamba (Dic) & 221,0 & 0,2253 \\
$\mathrm{GA}$ & 346,4 & 0,221 \\
IAA & $34,0,3464$ \\
IBA & 197,2 & 0,1972 \\
NAA & 203,2 & 0,2032 \\
Tidiazuron (TDZ) & 186,2 & 0,1862 \\
Zeatina (ZEA) & 220,2 & 0,2202 \\
ABA & 219,2 & 0,2192 \\
Cinetina (CIN) & 264,3 & 0,2643 \\
2ip & 215,2 & 0,2152 \\
\hline
\end{tabular}




\section{REFERÊNCIAS BIBLIOGRÁFICAS}

ADAMES, A.V.; LATADO, R.R.; CAMARGO, N.M.; TUlMANN NETO, A. Posição da gema e indução de mutação em mudas de crisântemo (Dendrathema grandiflora Tzvelev). Scientia Agricola, v.56, n.4, p.939-945, 1999.

AHLOOWALIA, B.S. In vitro techniques and mutagenesis for the improvement of vegetatively propagated plants. In: JAIN, S.M.; BRAR, D.S.; AHLOOWALIA, B.S. (Ed.). Somaclonal variation and induced mutations in crop improvement. London: Kluwer Academic Publishers, 1998. cap.15, p.293-310.

AHLOOWALIA, B.S.; MALUSZYNSKI, M. Induced mutations: a new paradigm plant breeding. Euphytica, v.118, p.167-173, 2001.

ALBUQUERQUE, F.C. de; DUARTE, M. de L.R. Pimenta-do-reino e suas doenças na Região Amazônica. Correio Agrícola, v.213, p.114-119, 1977.

ALBUQUERQUE, F.C. de; DUARTE, M. de L.R.; NUNES, A.M.L.; STEIN, R.L.B.; OLIVEIRA, R.P. de. Comportamento de germoplasma de pimenta-do-reino em áreas de ocorrência de fusariose no Estado do Pará. In: SEMINÁRIO INTERNACIONAL SOBRE PIMENTA-DO-REINO E CUPUAÇU, 1., Belém, 1996. Anais. Belém: EMBRAPA Amazônia Oriental / JICA, 1997. p.297-305. (Documentos, 89)

ALBUQUERQUE, F.C. de; FERRAZ, S. Características morfológicas e fisiológicas de Nectria haematococeae f. sp. piperis e sua patogenicidade a pimenta-do-reino. Experimentiae, v.22, p.133-151, 1976.

ALBUQUERQUE, F.C.; CONDURÚ, J.M.P. Cultura da pimenta do reino na Região Amazônica. Belém: IPEAN, 1971. 149p. (Série Fitotecnia, v.2, n.2)

ALBUQUERQUE, F.C.; DUARTE, M.L.R. Comportamento de cultivares de pimentado-reino em áreas de ocorrência de fusariose no Estado Pará. Belém: EMBRAPA, CPATU, 1991. 40p. (Documentos, 59) 
ALBUQUERQUE, F.C.; VELOSO, C.A.C.; DUARTE, M. de L.R.; KATO, O.R. Pimentado-reino: recomendações básicas para seu cultivo. Belém: EMBRAPA, UEPAE de Belém, 1989. 40p. (Documentos, 12)

ANDO, A.; AlBUQUERQUE, F.C. de.; POLTRONIERI, M.C.; TULMANN NETO, A. Obtenção de mutantes resistentes à fusariose (Fusarium solani f. sp. piperis) em pimenta-do-reino (Piper nigrum L.) através de irradiação gama. In: SEMINÁRIO INTERNACIONAL SOBRE PIMENTA-DO-REINO E CUPUAÇU, 1., Belém, 1996.

Anais. Belém: EMBRAPA Amazônia Oriental / JICA, 1997. p.237-243. (Documentos, 89)

ANDO, A.; MENTEN, J.O.M.; TULMANN NETO, A.; ALBUQUERQUE, F.C. de.; HIRAKATA, K. Obtenção de mutantes resistentes àfusariose em pimenta-do-reino (Piper nigrum L.). In: SEMINÁRIO REGIONAL SOBRE TÉCNICAS NUCLEARES NA PRODUÇÃO DE PlantAS AGRíCOlAS, 1., Piracicaba, 1984. Anais. Piracicaba: CENA/USP, 1984. p.47-49.

ARYA, S.; KALIA, R.K.; ARYA, I.D. Induction of somatic embryogenesis in Pinus roxburghii Sarg. Plant Cell Reports, v.19, p.775-780, 2000.

BANERJEE, N.; DE LANGHE, E. A tissue culture technique for rapid clonal propagation and storage under minimal growth conditions of Musa (banana and plantain). Plant Cell Reports, v.4, p.351-354, 1985.

BARAKAT, M.N.; ABEL-LATIF, T.H. In vitro selection of wheat callus tolerant to high levels of salt and plant regeneration. Euphytica, v.91, p.127-140, 1996.

BECKMAN, C.H. The nature of wilt diseases of plants. St. Paul: APS Press, 1987. cap.5, p.83-102: The expressive phase of the disease.

BIAHOUA, A.; BONNEAU, L. Control of in vitro somatic embryogenesis of the spindle tree (Euonymus europaeus L.) by the sugar type and the osmotic potential of the culture medium. Plant Cell Reports, v.19, p.185-190, 1999.

BORRÁS, O.; SANTOS, R.; MATOS, A.P.; CABRAL, R.S.; ARZOLA, M. A first attempt to use a Fusarium subglutinans culture filtrate for the selection of pineapple cultivars resistant to fusariose disease. Plant Breeding, v.120, p.435-438, 2001.

CABONI, E.; LAURI, P.; D'ANGELI, S. In vitro plant regeneration from callus of shoot apices in apple shoot culture. Plant Cell Reports, v.19, p.755-760, 2000. 
CASSELLS, A.C. In vitro-induced mutation for disease resistance. In: JAIN, S.M.; BRAR, D.S.; AHLOOWALIA, B.S. (Ed.). Somaclonal variation and induced mutations in crop improvement. London: Kluwer Academic Publishers, 1998. cap.18, p.367-378.

CHEN, J.T.; CHANG, C.; CHANG, W.C. Direct somatic embryogenesis on leaf explants of Oncidium gower Ramsey and subsequent plant regeneration. Plant Cell Reports, v.19, p.143-149, 1999.

CORNELISSEN, B.J.C.; MELCHERS, L.S. Strategies for control of fungal diseases with transgenic plants. Plant Physiology, v.101, p.709-712, 1993.

CRONAUER, S.S.; KRIKORIAN, A.D. Rapid multiplication of bananas and plantains by in vitro shoot tip culture. HortScience, v.19, p.324-325, 1984.

CUENCA, B.; SAN-JOSÉ, M.C.; MARTINEZ, M.T.; BALLESTER, A.; VIEITEZ, A.M. Somatic embryogenesis from stem and leaf explants of Quercus robur L. Plant Cell Reports, v.18, p.538-543, 1999.

DASGUPA, A.; DATTA, P.C. Cytotaxonomy of piperaceae. Cytologia, v.41, p.697706, 1976.

DAUB, M.E. Tissue culture and the selection of resistance to pathogens. Annual Review Phytopathology, v.24, p.159-186, 1986.

De BLOCK, M. The cell biology of plant transformation: current state, problems, prospects and the implications for the plant breeding. Euphytica, v.71, p.1-14, 1993.

DONINI, P.; SONNINO, A. Induced mutation in plant breeding: current status and future outlook. In: JAIN, S.M.; BRAR, D.S.; AHLOOWALIA, B.S. (Ed.). Somaclonal variation and induced mutations in crop improvement. London: Kluwer Academic Publishers, 1998. cap.14, p.255-292.

DUARTE, M. de L.R. Toxic metabolites of Nectria haematococca f. sp. piperis and their role in pathogenesis on black pepper, Piper nigrum L. Ascot, 1993. 213p. Thesis (Ph.D.) - University of London.

DUARTE, M. de L.R.; ALBUQUERQUE, F.C. Doenças da cultura da pimenta-do-reino. In: DUARTE, M. de L.R. (Ed.). Doenças de plantas no trópico úmido. Belém: Embrapa Amazônia Oriental, 1999. p.159-208. 
FUNDAÇÃO INSTITUTO BRASILEIRO DE GEOGRAFIA E ESTATÍSTICA - IBGE. Levantamento sistemático da produção agrícola. Rio de Janeiro, nov. 2000. p.1-6.

GANAPATHI, T.R.; HIGGS, N.S.; BALINT-KURTI, P.J.; ARNTZEN, C.J.; MAY, G.D.; VAN ECK, J.M. Agrobacterium mediated transformation of embryogenic cell suspensions of the banana cultivar Rasthali (AAB). Plant Cell Reports, v.20, p.157-162, 2001.

GAO, M.W.; CAI, Q.H.; LIANG, Z.Q. In vitro culture of hybrid indica rice combined with mutagenesis. Euphytica, v.108, p.104-110, 1992.

GRATTAPAGLIA, D.; MACHADO, M.A. Micropropagação. In: TORRES, A.C.; CALDAS, L.S.; BUSO, J.A. (Ed.). Cultura de tecidos e transformação genética de plantas. Brasília: Embrapa, SPI / Embrapa, CNPH, 1998. v.1, p.183-260.

HIDALGO, O.B.; SANTOS, R.; MATOS, A.P.; CABRAL, R.S.; TUSSEL, R.T.; ARZOLA, M.; SANTOS, R.; PÉREZ, M.C. Phytotoxic effect of culture filtrate from Fusarium subglutinans the causal agent of fusariose of pineapple (Ananas comosus (L.) Merr. Euphytica, v.104, p.73-77, 1998.

HIDALGO, O.B.; SANTOS, R.; TUSSEL, R.T.; MATOS, A.P.; CABRAL, R.S.; ARZOLA, M.; SANTOS, R.; PÉREZ, M.C. Phytotoxity of fusarium subglutinans culture filtrates on in vitro plantlets and calli of resistant and susceptible pineapple (Ananas comosus). Plant Pathology, v.48, p.756-758, 1999.

HU, C.Y.; FERREIRA, A.G. Cultura de embriões. In: TORRES, A.C.; CALDAS, L.S.

Técnicas e aplicações da cultura de tecidos de plantas. Brasília: ABCTP; EMBRAPA, CHPH, 1990. p.71-85.

IANTCHEVA, A.; VLAHOVA, M.; BAKALOVA, E.; KONDOROSI, E.; ELLIOTT, M.C.; ATANASSOV, A. Regeneration of diploid annual medics via indirect somatic embryogenesis promoted by thidiazuron and benzylaminopurine. Plant Cell Reports, v.18, p.904-910, 1999.

INSTITUTO BRASILEIRO DE GEOGRAFIA E ESTATÍSTICA - IBGE. Agricultura produção, área, rendimento, importações e exportações - Brasil - 1991 a 2000: lavouras permanentes / pimenta-do-reino. http://www. Ibge.gov.br. (21 out. 2002)

INTERNATIONAL ATOMIC ENERGY AGENCY - IAEA. Manual on mutation breeding. Viena, 1977. 217p. (Technical Reports Series, 119) 
INTERNATIONAL PEPPER COMMUNITY - IPC. International pepper news bulletin. Jakarta, July-Sept. 1997. p.50-54.

JAIN, S.M. Tissue culture-derived variation in crop improvement. Euphytica, v.118, p.153-166, 2001.

JIN, H.; HARTMAN, G.L.; NICKELL, C.D.; WIDHOLM, J.M. Phytotoxicity of culture filtrate from Fusarium solani, the causal agent of Soybean Sudden Death Syndrome. Plant Disease, v.80, p.922-927, 1996.

JOHANSEN, D.A. The chromosomes of Piper subpeltatum. Piper, v.1, p.134-135, 1931.

JOSEPH, B.; JOSEPH, D.; PHILIP, V.J. Plant regeneration from somatic embryos in black pepper. Plant Cell, Tissue and Organ Culture, v.48, p.87-90, 1996.

KE, J.; KHAN, R.; JOHNSON, T.; SOMERS, D.A.; DAS, A. High-efficiency gene transfer to recalcitrant plants by Agrobacterium tumefaciens. Plant Cell Reports, v.20, p.150-156, 2001.

KHOON, C.B.; TALIB, S.S. Effects of naphthalene acetic acid and two phenolic substances on rooting of pepper shoots cultures in vitro. MARDI Research Bulletin, v.13, n.1, p.108-110, 1985.

KINTZIOS, S.; MANOS, C.; MAKRI, O. Somatic embryogenesis from mature leaves of rose (Rosa sp.) Plant Cell Reports, v.18, p.467-472, 1999.

KONDO, T.; HASEGAWA, H.; SUZUKI, M. Transformation and regeneration of garlic (Allium sativum L.) by Agrobacterium-mediated gene transfer. Plant Cell Reports, v.19, p.989-993, 2000.

KRIKORIAN, A.D. Baseline and cell studies for use in banana improvement schemes. In: PLOETZ, R.C. (Ed.). Fusarium wilt of banana. St. Paul: APS Press, 1990. p.127133.

LATADO, R.R.; TULMANN NETO, A.; MENDES, B.M.J. Melhoramento de crisântemo (Dendrathema grandifolia Tzvelev.) cv.Repin Rosa, através da indução de mutação in vitro. Pesquisa Agropecuária Brasileira, v.31, n.7, p.489-496, 1996.

LEMOS, O.F. de. Embriogênese somática em três cultivares de bananeira (Musa spp., grupos AAA eAAB). Piracicaba, 1984. 149p. Dissertação (M.S) - Escola Superior de Agricultura “Luiz de Queiroz”, Universidade de São Paulo. 
LEMOS, O.F. de; MENEZES, I.C. de; SILVA, V.L. da. Propagação in vitro de plantas de pimenta-do-reino. In: SEMINÁRIO INTERNACIONAL SOBRE PIMENTA-DOREINO E CUPUAÇU, 1., Belém, 1996. Anais. Belém: EMBRAPA Amazônia Oriental / JICA, 1997. p.407-415. (Documentos, 89)

LYNCH, D.R.; COLEMAN, M.C.; LYON, G.D. Effect of Alternaria solani culture filtrate on adventitious shoot regeration in potato. Plant Cell Reports, v.9, p.607-610, 1991.

MALUSZYNSKI, M.; AHLOOWALIA, B.S.; SIGURBJÖRNSSON, B. Application of in vitro mutation techniques for crop improvement. Euphytica, v.85, p.303-315, 1995.

MATHEW, P.J.; MATHEW, P.M.; KUMAR, V. Graph clustering of Piper nigrum L. (black pepper). Euphytica, v.118, p.257-264, 2001.

MATHEW, P.M. Karyomorphological studies on Piper nigrum. Journal of Plantation Crops, v.4, p.15-18, 1974. Supplement.

MATHEWS, M.H.; RAO, P.S. In vitro responses of black pepper (Piper nigrum). Current Science, v.53, n.4, p.183-186, 1984.

MATSUMOTO, K.; SOUZA, L.A.C.; BARBOSA, M.L. In vitro selection for Fusarium wilt resistance in banana. I: Co-cultivation technique to produce culture filtrate of race 1 Fusarium oxysporum f. sp.Cubense. Fruits, v.54, p.97-102, 1999a.

MATSUMOTO, K.; BARBOSA, M.L.; SOUZA, L.A.C.; TEIXEIRA, J.B. In vitro selection for Fusarium wilt resistance in banana. II: resistance to culture filtrate of race 1 Fusarium oxysporum f. sp.Cubense. Fruits, v.54, p.151-157, 1999b.

MATSUMOTO, K.; BARBOSA, M.L.; SOUZA, L.A.C.; TEIXEIRA, J.B. Race I Fusarium wilt tolerance on banana plants selected fusaric acid. Euphytica, v.84, p.67-71, 1995.

McLEAN, M. The phytotoxicity of Fusarium metabolites: an update since 1989. Mycopathologia, v.133, p.163-179, 1996.

METHA, Y.R.; ANGRA, D.C. Somaclonal variation for disease resistance in wheat and production of dihaploids through wheat $x$ maize hybrids. Genetics and Molecular Biology, v.23, n.3, p.617-622, 2000.

MIGUEL, C.M.; OLIVEIRA, M.M. Transgenic almond (Prunus dulcis Mill.) plants obtained by Agrobaterium - mediated transformation of leaf explants. Plant Cell Reports, v.18, p.387-393, 1999. 
MORPURGO, R.; LOPATO, S.V.; AFZA, R.; NOVAK, F.J. Selection parameters for resistance to Fusarium oxysporum $f$. sp. cubense race 1 and 4 on diploid banana (Musa acuminata Colla). Euphytica, v.75, p.121-129, 1994.

MURASHIGE, T.; SKOOG, F. A revised medium for rapid growth and bioassays with tobacco tissue cultures. Physiology Plantarum, v.15, p.473-497, 1962.

MURCH, S.J.; CHOFFE, K.L.; VICTOR, J.M.R.; SLIMMON, T.Y.; KRISHNARAJ, S.; SAXENA, P.K. Thidiazuron-induced plant regeneration from hypocotyls cultures of St. John's wort (Hypericum perforatum cv."Anthos”). Plant Cell Reports, v.19, p.576-581, 2000.

NAMBIAR, P.K.V.; PILLAY, V.S.; SASIKUMARAN, S.; CHANDY, K.C. Pepper research at panniyur: a resume. Journal of Plantation Crops, v.6, n.1, p.4-11, 1978.

NG, S.Y.C.; NG, N.O. Reduced-growth storage of germoplasm. In: DODS, J.H. (Ed.). In vitro methods for conservation of plant genetic resources. New York: Chapman and Hall, 1991. p.11-40.

NITZSCH, W. Germoplasm preservation. In: EVANS, D.A.; SHARP, W.R.; AMMIRATO, P.V.; YAMADA, Y. (Ed.). Handbook of plant cell culture: techniques for propagation and breeding. New York: Macmillan, 1983. v.1, p.782-805.

OKAJIMA, H. Colheita, produção, beneficiamento e mercado externo da pimenta-doreino. In: SEMINÁRIO INTERNACIONAL SOBRE PIMENTA-DO-REINO E CUPUAÇU, 1., Belém, 1996. Anais. Belém: EMBRAPA Amazônia Oriental / JICA, 1997. p.237-243. (Documentos, 89)

OLDACH, K.H.; MORGENSTERN, A.; ROTHER, S.; GIRGI, M.; O'KENNEDY, M.; LÖRZ, H. Efficient in vitro plant regeneration from immature zygotic embryos of pearl millet [Pennisetum glaucum (L.) R. Br.] and Sorgum bicolor (L.) Moench. Plant Cell Reports, v.20, p.416-421, 2001.

PATHIRANA, R. Gamma ray-induced field tolerance to Phytophthora blight in sesame. Plant Breeding, v.108, p.314-319, 1992.

PHILIP, V.J.; JOSEPH, D.; TRIGGS; G.S.; DICKINSON, N.M. Micropropagation of black pepper (Piper nigrum Linn.) through shoot tip cultures. Plant Cell Reports, v.12, p.42-44, 1992 
POLTRONIERI, M.C.; ALBUQUERQUE, F.C. de; POLTRONIERI, L.S. Avaliação de dois métodos de polinização em pimenta-do-reino. Belém: EMBRAPA, CPATU, 1993. 5p. (Comunicado Técnico, 74)

POLTRONIERI, M.C.; ALBUQUERQUE, F.C. de; POLTRONIERI, L.S. Obtenção de híbridos em pimenta-do-reino e avaliação em relação à fusariose. In: SEMINÁRIO INTERNACIONAL SOBRE PIMENTA-DO-REINO E CUPUAÇU, 1., Belém, 1996.

Anais. Belém: EMBRAPA Amazônia Oriental / JICA, 1997. p.417-427. (Documentos, 89)

POLTRONIERI, M.C.; LEMOS, O.F. de; ALBUQUERQUE, F.C. Pimenta-do-reino. In: EMPRESA BRASILEIRA DE PESQUISA AGROPECUÁRIA. Programa de melhoramento genético e adaptação de espécies vegetais para a Amazônia oriental. Belém: Embrapa Amazônia Oriental, 1999. p.127-137. (Documentos, 16) PREDIERI, S. Mutation induction and tissue culture in improving fruits. Plant Cell, Tissue and Organ Culture, v.64, p.185-210, 2001.

PREDIERI, S.; S. MAGLI, M.; ZIMMERMAN, R.H. Pear mutagenesis: in vitro treatment with gamma-rays and field selection for vegetative form traits. Euphytica, v.93, n.2, p.222-237, 1997.

PRZYBYLA, A. Mutagenesis en fitomejoramiento de plantas de propagación vegetativa. Revista Chapingo, v.1, p.145-150, 1994.

REMOTTI, P.C.; LÖFFLER, H.J.M.; VAN VLOTEN-DOTING, L. Selection of cell-lines and regeneration of plants resistant to fusaric acid from Gladiolus $X$ grandiflorus cv.“Peter Pears". Euphytica, v.96, p.237-245, 1997.

ROBINSON, J.C.; FRASER, C.; ECKSTEIN, K. A field comparison of conventional suckers with tissue culture banana planting material over three crop cycles. Journal of Horticultural Science, v.68, n.6, p.831-836, 1993.

ROCA, W.M. Cassava. In: SHARP, W.R.; EVANS, D.A.; AMMIRATO, P.V.; YAMADA, Y. (Ed.). Handbook of plant cell culture. New York: Macmillan, 1984. v.2, p.269301.

SANTANA, A.C. de; COSTA, R.M.O.; SOUZA, R. Comercialização da interno pimentado-reino no mercado interno. In: SEMINÁRIO INTERNACIONAL SOBRE PIMENTA-DO-REINO E QUPUAÇU, 1., Belém, 1996. Anais. Belém: EMBRAPA Amazônia Oriental / JICA, 1997. p.297-305. (Documentos, 89) 
SAXENA, S.; DHAWAN, V. Regeneration and large-scale propagation of bamboo (Dendrocalamus strictus Nees) through somatic embryogenesis. Plant Cell Reports, v.18, p.438-443, 1999.

SCHENK, R.U.; HILDEBRANDT, A.C. Medium and techniques for induction and growth of monocotyledonous and dicotyledonous plant cell cultures. Canadian Journal of Botany, v.69, p.199-204, 1972.

SEABROOK, J.E.A.; DOUGLASS, L.K. Somatic embryogenesis on various potato tissues from a range of genotypes and ploidy levels. Plant Cell Reports, v.20, p.175-182, 2001.

SHARMA, A.K.; BHATTACHARYYA, N.K. Chromosome studies on two genera of the family piperaceae. Genetica, v.29, p.256-289, 1959.

SHARMA, S.K.; RAMAMURTHY, V. Micropropagation of 4-year-old elite Eucalyptus tereticornis trees. Plant Cell Reports, v.19, p.511-518, 2000.

STANWOOD, P.C. Cryopreservation of seed germoplasm for genetic conservation. In: KARTHA, K.K. (Ed.). Cryopreservation of plant cells and organs. Boca Raton: CRC Press, 1985. p.199-226.

THOMAS, T.D.; BHATNAGAR, A.K.; BHOJWANI, S.S. Production of triploid plants of mulberry (Morus alba L.) by endosperm culture. Plant Cell Reports, v.19, p.395399, 2000.

TUlMANN NETO, A.; CAMARGO, C.E.O.; AlVES, M.C.; CASTRO, J.L.; GALLO, P.B. Indução de mutação visando a redução de altura de planta e resistência æ̀s doenças no cultivar de trigo (Triticum aestivum L.) IAC-17. Scientia Agrícola, v.52, n.2, p.287-293, 1995.

TULMANN NETO, A.; MENDES, B.M.J.; ANDO, A. Progresso na indução e uso de mutações in vitro. In: TORRES, A.C.; CALDAS, L.S.; BUSO, J.A. (Ed.). Cultura de tecidos e transformação genética de plantas. Brasília: Embrapa, SPI / Embrapa, CNPH, 1998. v.1, p.459-509.

VIEIRA, M.L.C.; APEZATO-DA-GLÓRIA, B. Fundamentos e aplicações da cultura de tecidos no melhoramento. In: NASS, L.L.; VALOIS, A.C.C.; MELO, I.S.; VALADARES-INGLIS, M.C. (Ed.). Recursos genéticos e melhoramento: plantas. Rondonópolis: Fundação MT, 2001. cap.28, p.911-938.

VUYLSTEKE, D.; DE LANGHE, E. Feasibility of in vitro propagation of bananas and plantains. Tropical Agriculture, v.62, n.4, p.323-328, 1985. 
WENZEL, G. Strategies in unconventional breeding for disease resistance. Annual Review Phytopathology, v.23, p.149-172, 1985.

XIE, D.Y.; HONG, Y. Regeneration of Acácia mangium through somatic embryogenesis. Plant Cell Reports, v.20, p.34-40, 2001.

YOSHIOKA, T.; MASUDA, T.; KOTOBUKI, K.; SANADA T.; ITO, Y. Gamma-rayinduced mutation breeding in fruit trees: breeding of mutant cultivars resistant to black spot disease in Japanese pear. Japan Agricultural Research Quarterly, v.33, n.4, p.227-234, 1999.

ZHANG, P.; LEGRIS, G.; COULIN, P.; PUONTI-KAERLAS, J. Production of stably transformed cassava plants via particle bombardment. Plant Cell Reports, v.19, p.939-945, 2000.

ZHANG, S.; CHO, M.J.; KOPREK, T.; YUN, R.; BREGITZER, P.; LEMAUX, P.G. Genetic transformation of commercial cultivars of oat (Avena sativa L.) and barley (Hordeum vulgare L.) using in vitro shoot meristematic cultures derived from germinated seedlings. Plant Cell Reports, v.18, p.959-966, 1999. 